\title{
ROBERTA BAPTISTA RODRIGUES
}

SSD RB - SISTEMA DE SUPORTE A DECISÃO PROPOSTO PARA A GESTÃo QUALI-QUANTITATIVA DOS PROCESSOS DE OUTORGA E COBRANÇA PELO USO DA ÁGUA

Tese de Doutorado apresentada à Escola Politécnica da Universidade de São Paulo, para obtenção do título de Doutora em Engenharia Civil, na área de Recursos Hídricos. 


\section{ROBERTA BAPTISTA RODRIGUES}

SSD RB - SISTEMA DE SUPORTE A DECISÃO PROPOSTO PARA

A GESTÃo QUALI-QUANTITATIVA DOS PROCESSOS DE

OUTORGA E COBRANÇA PELO USO DA ÁGUA

Tese de Doutorado apresentada à Escola Politécnica da Universidade de São Paulo, para obtenção do título de Doutora em Engenharia Civil, na área de Recursos Hídricos.

Área de Concentração:

Engenharia Hidráulica e Recursos Hídricos

Orientadora:

Profa. Dra. Monica Ferreira do Amaral Porto 
$\mathrm{Na}$ presente edição revisada foi inserida a Resolução $\mathrm{n}^{\circ} 48$, de 21 de março de 2005, assim como foi substituída a Resolução CONAMA ${ }^{\circ}$ 20 pela Resolução CONAMA n ${ }^{\circ}$ 357, de 17 de março de 2005. Ressalte-se que a versão original foi finalizada em fevereiro de 2005, ou seja, antes das referidas resoluções serem publicadas.

Rodrigues, Roberta Baptista

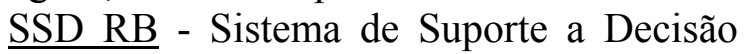
Proposto para a Gestão Quali-Quantitativa dos Processos de Outorga e Cobrança pelo Uso da Água. São Paulo, 2005. 155 p. Edição Revisada.

Tese (Doutorado) - Escola Politécnica da Universidade de São Paulo. Departamento de Engenharia Hidráulica e Sanitária.

Orientadora: Profa. Dra. Monica Ferreira do Amaral Porto.

1. Sistema de Suporte a Decisão. 2. Recursos Hídricos. 3. Outorga e Cobrança. 4. Modelagem. 5. Qualidade da água. 6. Modelos RM1 e QUAL2E.

I. Universidade de São Paulo. Escola Politécnica. Departamento de Engenharia Hidráulica e Sanitária.

II. $\mathrm{t}$ 
O SSD RB foi aceito pelo Centro Incubador de Empresas Tecnológicas (CIETEC), da Universidade de São Paulo (USP), como uma inovação tecnológica na área de gestão de recursos hídricos. Assim, em janeiro de 2005, a empresa RB RECURSOS HÍDRICOS iniciou suas atividades no CIETEC, no ramo de atuação de CONSULTORIA EM QUESTÕES DE SUSTENTABILIDADE DO MEIO AMBIENTE.

A RB RECURSOS HÍDRICOS atua em parceria com empresas de base tecnológica do CIETEC e com pesquisadores da universidade, através de sinergia, visando o desenvolvimento de produtos inovadores, tanto em nível nacional como internacional, que venham melhor atender as necessidades da sociedade e a custos mais acessíveis.

Missão da RB RECURSOS HÍDRICOS - Oferecer subsídios para o planejamento e gerenciamento do meio ambiente, auxiliados por tecnologia da informação, visando o desenvolvimento sustentável e o uso múltiplo da água, de forma a assegurar à atual e às futuras gerações água de boa qualidade.

\section{RB RECURSOS HÍDRICOS}

Localização: Avenida Professor Lineu Prestes, 2242 - IPEN/CIETEC - Butantã Cidade Universitária - CEP 05508-000 - São Paulo-SP.

Telefone: 55 (11) 3039-8364

E-mail: robertabr@gmail.com

Site: www.rbrecursoshidricos.com

Apoio:

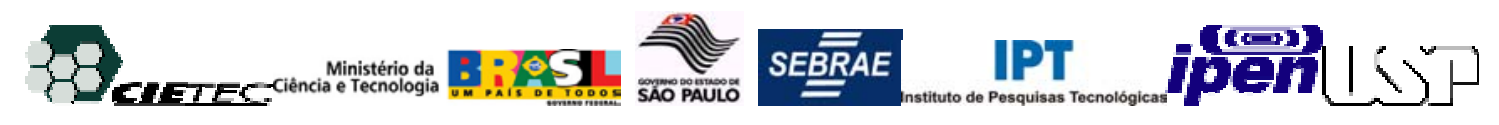


à minha mãe, Gracia 


\section{AGRADECIMENTOS}

Desejo expressar o meu sincero agradecimento à Profa. Dra. Monica Ferreira do Amaral Porto, que me conduziu no mundo das águas e cujo maior ensinamento foi o próprio exemplo de dedicação e amor ao trabalho.

à Escola Politécnica da Universidade de São Paulo, pelo oferecimento dos Programas de Mestrado e Doutorado.

à Coordenadoria de Aperfeiçoamento de Pessoal de Nível Superior (CAPES), pela bolsa de estudo oferecida nos primeiros meses de desenvolvimento do programa de doutorado, sem a qual a realização deste trabalho não teria sido possível.

à Companhia de Tecnologia de Saneamento Ambiental (CETESB), pelos dados fornecidos.

à Fundação Centro Tecnológico de Hidráulica (FCTH), pelos dados fornecidos.

ao Centro Incubador de Empresas Tecnológicas (CIETEC), da Universidade de São Paulo (USP), pelas oportunidades oferecidas.

à Maria Salete, pela revisão de texto.

a todos os amigos, colegas e profissionais, que indiretamente contribuíram para o desenvolvimento deste trabalho.

à minha família e amigos, pelo incentivo e apoio.

a meus avós que deixaram o legado do verdadeiro valor do caráter e do trabalho.

a Deus, por estar presente nos momentos mais difíceis. 


\section{SUMÁRIO}

Lista de figuras $\ldots \ldots \ldots \ldots \ldots \ldots \ldots \ldots \ldots \ldots \ldots$
Lista de tabelas
Lista de siglas e abreviações
Lista de símbolos
RESUMO
ABSTRACT

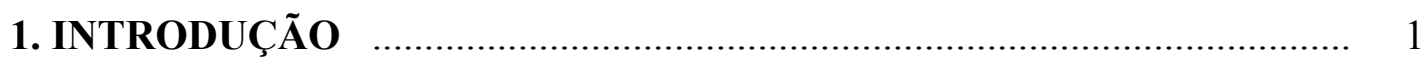

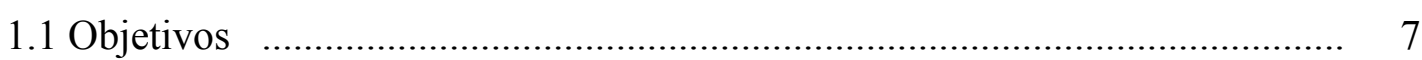

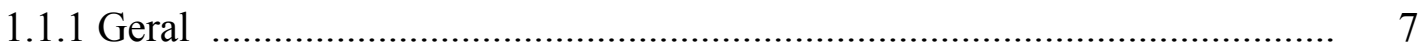

1.1.2 Específicos .................................................................................... 7

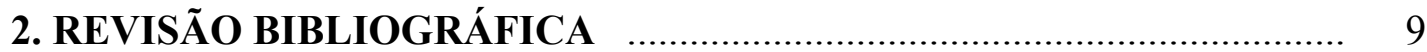

2.1 A Política Nacional de Recursos Hídricos ................................................ 9

2.1.1 Os Planos de Recursos Hídricos ...................................... 11

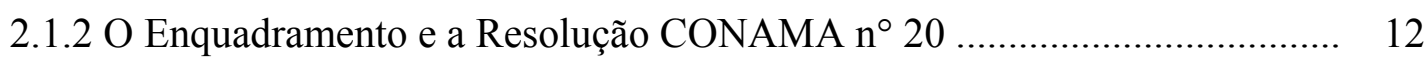

2.1.3 Outorga pelo uso da água ................................................................... 16

2.1.4 Cobrança pelo uso da água ..................................................................... 19

2.1.5 Sistema de Informações sobre Recursos Hídricos ................................... 32

2.2 Sistemas de suporte a decisão ............................................................ 34

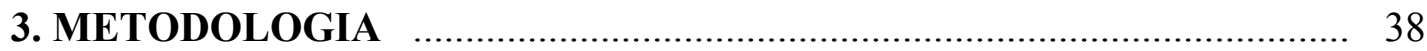

3.1 Processo de autodepuração em rios ............................................................. 38

3.1.1 Parâmetros de degradação, reaeração e sedimentação e demanda bentônica de oxigênio .............................................................................................. 40

3.2 Modelagem da qualidade da água ......................................................... 43

3.3 Modelo de qualidade das águas QUAL2E .................................................. 46

3.3.1 Motivos da escolha do modelo QUAL2E para o SSD RB ........................ 46

3.3.2 Características do modelo .................................................................... 47

3.3.3 Equações do modelo QUAL2E .......................................................... 47

3.3.4 Estrutura conceitual e alocação de cargas ................................................ 52

3.4 Modelo de outorga e cobrança pelo uso da água RM1 ............................... 54

3.4.1 Características do modelo ......................................................................... 54

3.4.2 Estrutura conceitual ........................................................................... $\quad 55$

3.4.3 Equações do modelo RM1 ............................................................... 55

3.4.4 Condições a serem respeitadas .......................................................... 57 
3.4.5 Determinação do valor a ser pago pelo usuário-poluidor, considerando os dados ocasionados na qualidade da água captada

3.4.6 Determinação do valor a ser pago pelo usuário de captação considerando a qualidade da água captada 59

3.5 Modelagem do sistema de suporte a decisão RB ....................................... 59

3.5.1 Função do modelo QUAL2E .................................................................. 65

3.5.2 Função do modelo RM1 ......................................................................... 66

3.5.3 Função da base de dados .......................................................................... 67

3.5.4 Interface gráfica do SSD RB ............................................................. 67

3.5.5 Linguagem de programação do sistema ................................................... 67

3.6 Articulação do SSD RB com os instrumentos de gestão .............................. 68

\section{ESTUDO DA BACIA DO RIO JUNDIAÍ PARA APLICAÇÃO DO SSD} RB

4.1 Bacia do rio Jundiaí .............................................................................. $\quad 70$

4.1.1 Dados pluviométricos e fluviométricos ................................................. 73

4.1.2 A industrialização e as cargas poluidoras ................................................ 75

4.1.3 Qualidade das águas do rio Jundiaí ........................................................ 77

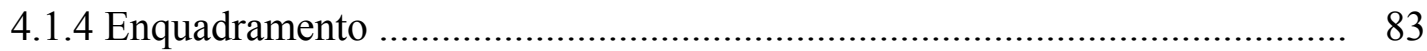

4.2 Dados de entrada do modelo QUAL2E e calibração .................................... 83

4.2.1 Entrada de dados ......................................................................... 83

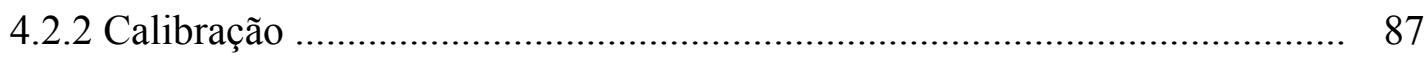

5. RESULTADOS E DISCUSSÕES ................................... 96

5.1 Apresentação do sistema de suporte a decisão RB .......................... 97

5.2 Manual do SSD RB ..................................................... 96

5.2.1 Fatores considerados pelo SSD RB para os processos de outorga e

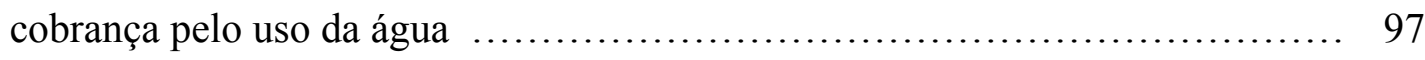

5.2.2 Limitações e medidas de contorno do SSD RB ........................... 97

5.2.3 Especificação de hardware e software ................................ 98

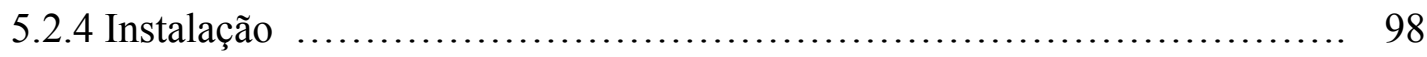

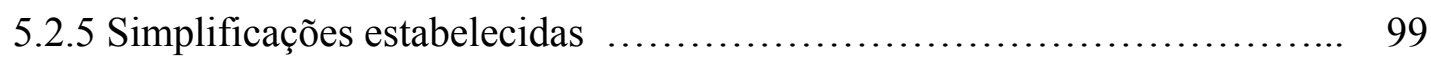

5.2.6 Dados de entrada ............................................... 99

5.2.7 Dados de saída do SSD RB ............................................. 113

5.3 Aplicação do SSD RB na bacia do rio Jundiá ................................ 121

5.3.1 Cenários e resultados da aplicação do SSD RB na bacia do rio Jundiaí .. 121

6. CONCLUSÕES E RECOMENDAÇÕES ............................................. 135

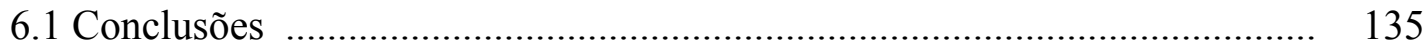


REFERÊNCIAS BIBLIOGRÁFICAS _.............................................. 144

1.Referências bibliográficas consultadas e citadas no texto .............................. 144

2. Referências bibliográficas consultadas f..................................................... 152 


\section{FIGURAS}

Figura 2.1 - Estrutura típica de um sistema de suporte a decisão, pág. 34

Figura 3.1 - Perfil esquemático dos processos de degradação e recuperação de um rio, pág. 39

Figura 3.2 - Esquema de um protótipo para um sistema hídrico ramificado, pág. 53

Figura 3.3 - Representação esquemática do modelo RM1, pág. 55

Figura 3.4 - Estrutura do SSD RB, pág. 62

Figura 3.5 - Fluxograma de dados do SSD RB, pág. 64

Figura 3.6 - Uso do SSD RB articulado com os instrumentos de gestão, pág. 69

Figura 4.1 - Bacia do rio Jundiaí, pág. 71

Figura 4.2 - Índice de Qualidade das Águas (IQA) do rio Jundiaí, pág. 71

Figura 4.3 - Localização da Bacia do rio Jundiaí no Estado de São Paulo (SP), pág. 72

Figura 4.4 - Precipitação média mensal entre postos na bacia em estudo, pág. 74

Figura 4.5 - Vazão média mensal no posto 3E-108 do rio em estudo, pág. 75

Figura 4.6 - Vazão média mensal no posto 4E-017 do rio em estudo, pág. 75

Figura 4.7 - Carga orgânica doméstica e industrial gerada e lançada na rede de esgoto, pág. 77

Figura 4.8 - Concentração média anual de OD no posto JUNA-2020, pág. 79

Figura 4.9 - Concentração média anual de DBO no posto JUNA-2020, pág. 79

Figura 4.10 - Concentração média anual de OD no posto JUNA-4270, pág. 80

Figura 4.11 - Concentração média anual de DBO no posto JUNA-4270, pág. 80

Figura 4.12 - Concentração média anual de OD no posto JUNA-4900, pág. 81

Figura 4.13 - Concentração média anual de DBO no posto JUNA-4900, pág. 81

Figura 4.14 - Dados pluviométricos na Bacia do Alto Tietê, pág. 82

Figura 4.15 - Diagrama unifilar e alocação de cargas para a calibração do modelo QUAL2E, pág. 84

Figura 4.16 - Representação "box plots" utilizada para a calibração do modelo QUAL2E, pág. 92

Figura 4.17 - Variação do OD para os meses de jan/fev/mar, pág. 93

Figura 4.18 - Variação da DBO para os meses de jan/fev/mar, pág. 93

Figura 4.19 - Variação do OD para os meses de abr/maio/jun, pág. 93 
Figura 4.20 - Variação da DBO para os meses de abr/maio/jun, pág. 93

Figura 4.21 - Variação do OD para os meses de jul/ago/set, pág. 94

Figura 4.22 - Variação da DBO para os meses de jul/ago/set, pág. 94

Figura 4.23 - Variação do OD para os meses de out/nov/dez, pág. 94

Figura 4.24 - Variação da DBO para os meses de out/nov/dez, pág. 94

Figura 5.1 - Formulário de inicialização, pág. 100

Figura 5.2 - Formulário de Identificação (Rodada, Trecho, Elemento), pág. 100

Figura 5.3 - Formulário de Dados Hidráulicos, Climáticos e Geográficos e Formulário de Inserção Rápida de Dados, pág. 104

Figura 5.4 - Formulário de Variáveis de Qualidade da Água e Fator de Correção de Temperatura, pág. 107

Figura 5.5 - Formulário de Constates de Reação (OD e DBO) e Condição Inicial do Rio, pág. 108

Figura 5.6 - Formulário de Dados de Cabeceira e Fluxo Incremental, pág. 111

Figura 5.7 - Formulário Coeficientes e Carga Pontual e Captação, pág. 112

Figura 5.8 - Formulário de Enquadramento, pág. 112

Figura 5.9 - Formulário com gráfico de qualidade da água, pág. 116

Figura 5.10 - Formulário com gráfico de dados hidráulicos, pág. 116

Figura 5.11 - Formulário com gráfico de dados de qualidade da água entre cenários, pág. 117

Figura 5.12 - Formulário com gráfico de dados hidráulicos entre cenários, pág. 117

Figura 5.13 - Formulário de saída do SSD RB 'RM1 - Vazão de Diluição', pág. 119

Figura 5.14 - Formulário de saída do SSD RB ‘RM1 - Vazão Liberada', pág. 119

Figura 5.15 - Formulário de saída do SSD RB 'RM1 - QD de Captação; Custo’, pág. 120

Figura 5.16 - Formulário de saída do SSD RB ‘RM1 - Custo de QD e QC', pág. 120 


\section{TABELAS}

Tabela 2.1 - Tabela de "Preços Unitários Básicos", pág. 26

Tabela 2.2 - Coeficientes multiplicadores para lançamentos, pág. 27

Tabela 2.3 - Valores limites estimados para os Preços Unitários Finais, pág. 27

Tabela 3.1 - Ordem de grandeza da taxa de degradação $\left(\mathrm{K}_{1}\right)$ a $20{ }^{\circ} \mathrm{C}$, assumida em laboratório, pág. 40

Tabela 3.2 - Equações para o parâmetro de reaeração $\mathrm{K}_{2}\left(\mathrm{dia}^{-1}\right)$, a $20^{\circ} \mathrm{C}$, pág. 41

Tabela 3.3 - Valores típicos do parâmetro de reaeração $\mathrm{K}_{2}\left(\mathrm{~d}^{-1}\right)$, a $20^{\circ} \mathrm{C}$, pág. 41

Tabela 3.4 - Sedimentabilidade das partículas suspensas e colóides suspensos, pág. 42

Tabela 3.5 - Valores associados à demanda de oxigênio da camada bentônica, pág. 42

Tabela 3.6 - Equações incorporadas ao modelo QUAL2E para previsão do coeficiente de reaeração, $\mathrm{K}_{2}\left(\mathrm{~d}^{-1}\right)$, a $20{ }^{\circ} \mathrm{C}$, pág. 50

Tabela 4.1 - População na Bacia do rio Jundiaí, pág. 72

Tabela 4.2 - Rede de amostragem pluviométrica do DAEE na bacia em estudo, pág. 73

Tabela 4.3 - Dados pluviométricos da Bacia do rio Jundiaí, pág. 73

Tabela 4.4 - Rede de amostragem fluviométrica do DAEE na bacia em estudo, pág. 74

Tabela 4.5 - Vazão média mensal na Bacia do rio Jundiaí, pág. 74

Tabela 4.6 - Carga orgânica industrial potencial lançada na Bacia do rio Jundiaí (ano de 1996), pág. 76

Tabela 4.7 - Carga orgânica industrial remanescente gerada na Bacia do rio Jundiaí (ano de 1996), pág. 76

Tabela 4.8 - Carga orgânica doméstica gerada na Bacia do rio Jundiaí (ano de 1996), pág. 76

Tabela 4.9 - Carga lançada no rio Jundiaí para calibração do modelo QUAL2E (ano de 1996), pág. 86

Tabela 4.10 - Vazão média trimestral considerada para calibração do modelo QUAL2E, pág. 87

Tabela 4.11 - Velocidade média no rio Jundiaí, pág. 88 
Tabela 4.12 - Profundidade média no rio Jundiaí, pág. 89

Tabela 4.13 - Fórmulas utilizadas para cálculo de $\mathrm{K}_{2}$ no rio Jundiaí, pág. 89

Tabela 4.14 - Valores de $\mathrm{K}_{3}$ para o rio Jundiaí, pág. 90

Tabela 4.15 - Valores de $\mathrm{K}_{1}$ para o rio Jundiaí, pág. 91

Tabela 4.16 - Valores de OD e DBO no rio Jundiaí, pág. 91

Tabela 4.17 - Valores de vazão em regimes $Q_{7,10}, Q_{95}, Q_{90}$ e Qm, pág. 95

Tabela 5.1 - Caracterização dos dados Hidráulicos, Climáticos e Geográficos, pág. 105

Tabela 5.2 - Caracterização dos dados de entrada das variáveis de qualidade da água, pág. 106

Tabela 5.3 - Valores das constantes de reação de OD e DBO, pág. 108

Tabela 5.4 - Dados de parâmetros e variáveis, pág. 109

Tabela 5.5 - Coeficientes para a série de nitrogênio e fósforo, coliforme fecal e nãoconservativo, pág. 111

Tabela 5.6 - Saída do SSD RB para os dados liberados pelo modelo QUAL2E, pág. 114

Tabela 5.7 - Unidade dos dados de saída dos formulários 'Variáveis' e 'Coeficientes de Reação', pág. 115

Tabela 5.8 - Unidade dos dados de saída dos formulários ‘Balanço de OD’ e 'Dados Hidráulicos', pág. 115

Tabela 5.9 - Saída do SSD RB para os dados liberados pelo modelo RM1, pág. 118

Tabela 5.10 - Cenários de aplicação do SSD RB na bacia o rio Jundiaí, pág. 121

Tabela 5.11 - Vazão de diluição, vazão liberada e custos, para o Lançamento 1, pág. 124

Tabela 5.12 - Vazão de diluição, vazão liberada, vazão de diluição de captação e custos, em função da Classe de Uso, pág. 125

Tabela 5.13 - Valores de captação em função da Classe de Uso, pág. 125

Tabela 5.14 - Vazão de diluição, vazão liberada por lançamento, vazão de diluição de captação e custos, em função da vazão simulada, pág. 127

Tabela 5.15 - Valores de captação em função da vazão simulada, pág. 128

Tabela 5.16 - Vazão liberada para outorga em função do regime de vazão e da Classe de Uso simuladas, pág. 128

Tabela 5.17 - Custos de lançamento em função dos valores unitários adotados para diluição e captação, pág. 131 
Tabela 5.18 - Custo de captação em função dos valores unitários adotados para diluição e captação, pág. 131

Tabela 5.19 - Cenários de aplicação do SSD RB e conclusões obtidas, pág. 133 


\section{SIGLAS E ABREVIAÇÕES}

AAgISA - Sistema de Gestão de Outorga do Estado da Paraíba

ACQUANET - Modelo de Rede de Fluxo com diversos módulos de análise

ABRH

- Associação Brasileira de Recursos Hídricos

ANA

- Agência Nacional de Águas

APRH

- Associação Portuguesa de Recursos Hídricos

BID

- Banco Interamericano de Desenvolvimento

Cap.

- Captação

CBH

- Comitê de Bacia Hidrográfica

CBH-PCJ

- Comitê das Bacias Hidrográficas dos Rios Piracicaba, Capivari e Jundiaí

CEETEPS - Centro Estadual de Educação Tecnológica Paula Souza

CEIVAP

- Comitê para Integração da Bacia do Rio Paraíba do Sul

CETESB

- Companhia de Tecnologia de Saneamento Ambiental

CE-QUAL-R1 - Modelo Unidimensional de Qualidade da Água de Reservatórios

CE-QUAL-W2 - Modelo Bi-Dimensional de Qualidade da Água de Reservatórios

CI

- Carga Inorgânica

CIETEC - Centro Incubador de Empresas Tecnológicas da USP

CLP

- Campo Limpo Paulista

CNRH

- Conselho Nacional de Recursos Hídricos

Coef.

- Coeficiente

CONAMA

- Conselho Nacional do Meio Ambiente

Cons.

- Consumo

COPLASA

- Consórcio Figueiredo Ferraz

CRH

- Conselho Estadual de Recursos Hídricos

DAEE

- Departamento de Águas e Energia Elétrica do Estado de São Paulo

DBO

- Demanda Bioquímica de Oxigênio

DBOu

- Demanda Bioquímica de Oxigênio total

DBOr

- Demanda Bioquímica de Oxigênio remanescente

DBOe

- Demanda Bioquímica de Oxigênio exercida

DBO $_{5,20}$

- Demanda Bioquímica de Oxigênio exercida, na temperatura de 20 ${ }^{\circ} \mathrm{C}$, no período de 5 dias 


\begin{tabular}{|c|c|}
\hline Dec. & - Decaimento (degradação) \\
\hline DH & - Dados Hidráulicos \\
\hline DQO & - Demanda Química de Oxigênio \\
\hline EDUSP & - Editora da Universidade de São Paulo \\
\hline EPA & - "Environmental Protection Agency" \\
\hline EPUSP & - Escola Politécnica da Universidade de São Paulo \\
\hline ETE & - Estação de Tratamento de Esgoto \\
\hline FATEC-SP & - Faculdade de Tecnologia de São Paulo \\
\hline FEHIDRO & - Fundo Estadual de Recursos Hídricos do Estado de São Paulo \\
\hline FCTH & - Fundação Centro Tecnológico de Hidráulica \\
\hline IICA & - Instituto Interamericano de Cooperação para Agricultura \\
\hline IQUAL & - Instituto de Qualificação \\
\hline QA & - Qualidade da Água \\
\hline QualidadeCLS & - Modelo de Qualidade da Água de rios \\
\hline QC & - Vazão de Captação \\
\hline Qcrit. & - Vazão crítica \\
\hline QD & - Vazão de Diluição \\
\hline QL & - Vazão Liberada \\
\hline QUAL2E & - Modelo de Qualidade da Água de Rios \\
\hline QUAL2R & - Interface Gráfica para o Modelo QUAL2E \\
\hline Q2E & - Modelo QUAL2E \\
\hline IBGE & - Instituto Brasileiro de Geografia e Estatística \\
\hline IQA & - Índice de Qualidade das Águas \\
\hline Lanç. & - Lançamento \\
\hline Lib. & - Liberação \\
\hline $\mathbf{L 1} \ldots \mathbf{L} 10$ & - Lançamento 1 .... Lançamento 10 \\
\hline MODSIM & - Modelo de Rede de Fluxo \\
\hline ModSimLSA & $\begin{array}{l}\text { - Modelo de Rede de Fluxo com um módulo de qualidade da água } \\
\text { para rios }\end{array}$ \\
\hline ModSimP32-E & $\begin{array}{l}\text { - Modelo de Rede de Fluxo com um módulo de estudo de impacto } \\
\text { econômico }\end{array}$ \\
\hline OD & - Oxigênio Dissolvido \\
\hline PPU & - Preço Público Unitário \\
\hline PT & - Carga ou concentração potencial gerada \\
\hline
\end{tabular}




\begin{tabular}{|c|c|}
\hline PUB & - Preço Unitário Básico \\
\hline PUF & - Preço Unitário Final \\
\hline PUM & - Preço Unitário Máximo \\
\hline RBRH & - Revista Brasileira de Recursos Hídricos \\
\hline $\mathbf{R M}$ & - Carga ou concentração efetivamente lançada \\
\hline RM1 & - Modelo Matemático de Outorga e Cobrança pelo Uso da Água \\
\hline RM2 & $\begin{array}{l}\text { - Modelo Matemático de Quantificação da Carga de Poluentes em } \\
\text { Rios }\end{array}$ \\
\hline RS & - Resíduo Sólido \\
\hline SAD & - Sistema de Apoio a Decisão para Pleito de Outorga e Cobrança \\
\hline Sed. & Sedimentação \\
\hline SEMA & - Secretaria Estadual do Meio Ambiente \\
\hline SISMODH & - Sistema Modular de Avaliação da Disponibilidade Hídrica \\
\hline SSD & - Sistema de Suporte a Decisão \\
\hline SSD RB & $\begin{array}{l}\text { - Sistema de Suporte a Decisão para a Gestão Quali-Quantitativa } \\
\text { dos Processos de Outorga e Cobrança pelo Uso da Água }\end{array}$ \\
\hline UFESP & - Unidade Fiscal do Estado de São Paulo \\
\hline UFSGS & - Universidade Federal do Rio Grande do Sul \\
\hline UNEP & - "United Nations Environmental Programme" \\
\hline USEPA & - "United Sates Environmental Protection Agency" \\
\hline USP & - Universidade de São Paulo \\
\hline VMP & - Valor Máximo Permissível \\
\hline VP & - Várzea Paulista \\
\hline
\end{tabular}




\section{SÍMBOLOS}

A - Área da seção transversal, $\left(\mathrm{m}^{2}\right)$

$\mathbf{A}_{1} \quad$ - Concentração de biomassa algal, $(\mathrm{mg} \mathrm{A} / \mathrm{L})$

$\mathbf{a}, \mathbf{b}, \propto \mathbf{e}-$ Constantes empíricas dos coeficientes de descargas, (adimensional)

$\beta$

$\mathbf{a}_{1} \quad$ - Coeficiente de utilização quantitativo, ou seja, este coeficiente representa a quantidade de água realmente utilizada pelo usuário, (adimensional)

$\mathbf{a}_{2} \quad$ - Coeficiente qualitativo que representa o processo de autodepuração do poluente no sistema, (adimensional)

c - Coeficiente de Tsivoglou e Wallance, $(1 / \mathrm{m})$

C - Concentração

Ce - Concentração do poluente no efluente, $(\mathrm{mg} / \mathrm{L})$

Cpm - Concentração do poluente imediatamente a montante do ponto de lançamento do efluente, $(\mathrm{mg} / \mathrm{L})$

Cp*(x) - Concentração máxima permissível do poluente no corpo receptor, que poderá resultar do enquadramento do corpo hídrico em classe de uso ou de um plano de recuperação da bacia, $(\mathrm{mg} / \mathrm{L})$

Cpa(x) - Concentração do poluente no corpo receptor antes do lançamento do efluente, diluída na vazão do efluente, $(\mathrm{mg} / \mathrm{L})$

Cpd(x) - Concentração do poluente no corpo receptor após o lançamento do efluente, $(\mathrm{mg} / \mathrm{L})$

Ce\$ - Custo unitário por $\mathrm{m}^{3}$ de água captada, $\left(\mathrm{R} \$ / \mathrm{m}^{3}\right)$

Ce\$ $\$_{\text {Total }}$ - Custo total da vazão captada, considerando a qualidade da água, $(\mathrm{R} \$)$

Cs - Concentração de saturação de oxigênio dissolvido em condições locais de temperatura e pressão, $(\mathrm{mg} / \mathrm{L})$

Cs' - Concentração de oxigênio de equilíbrio, a 1 atmosfera de pressão, $(\mathrm{mg} / \mathrm{L})$

C\$ - Custo unitário por $\mathrm{m}^{3}$ de água locado no corpo receptor, $\left(\mathrm{R} \$ / \mathrm{m}^{3}\right)$

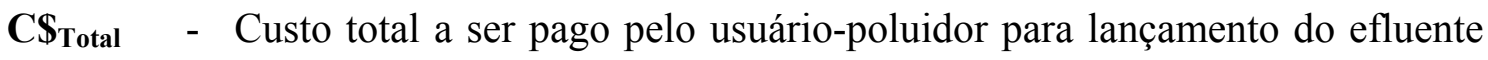
no corpo receptor, considerando os danos ocasionados na qualidade da água captada, $(\mathrm{R} \$)$

$\bar{C} \$$ - Custo médio a ser pago pelo usuário-poluidor para lançamento do efluente no corpo receptor, não considerando os danos ocasionados na qualidade da 
água captada, $(\mathrm{R} \$)$

$\mathbf{C}_{0} \quad$ - Concentração de oxigênio dissolvido, $(\mathrm{mg} / \mathrm{L})$

$\mathbf{C}_{2} \quad$ - Conta total a ser paga

D - Déficit de oxigênio dissolvido, $(\mathrm{mg} / \mathrm{L})$

De - Déficit crítico de oxigênio, $(\mathrm{mg} / \mathrm{L})$

DL - Coeficiente de dispersão longitudinal, (adimensional)

$\mathbf{d}_{\mathbf{p}, \mathbf{k}^{*}}(\mathbf{t}) \quad$ - Preço unitário do direito de uso da água, no trecho $\mathrm{k}^{*}$, no intervalo $\Delta \mathrm{t}$, (em $\$ / \mathrm{m}^{3}$ ou $\$ / \mathrm{m}^{3} / \mathrm{s}$ ) para diluir o poluente $\mathrm{p}>0$

D $\quad$ - déficit de oxigênio no instante " $\boldsymbol{t}$ "considerado, $(\mathrm{mg} / \mathrm{L})$

D $\quad$ - Déficit inicial de oxigênio dissolvido, no ponto de mistura do efluente com o corpo receptor, que é dado pela concentração de saturação menos a concentração de mistura, (mg/L)

$\mathbf{d}_{\mathbf{0}, \mathbf{k}^{*}}(\mathbf{t})$ - Preço unitário do uso consultivo da água, no trecho $\mathrm{k}^{*}$, no intervalo $\Delta \mathrm{t}$, (em $\$ / \mathrm{m}^{3}$ ou $\left.\$ / \mathrm{m}^{3} / \mathrm{s}\right)$

f - Número total de coeficientes multiplicadores, (adimensional)

F - Número de Froude, (adimensional)

g - Aceleração da gravidade, $\left(\mathrm{m} / \mathrm{s}^{2}\right)$

g $^{*} \quad$ - Usuário-poluidor de montante que prejudica o ponto de captação de jusante considerado, (adimensional)

H - Profundidade média, (m)

i $\quad$ - Espaço, $(\mathrm{km})$

$i^{*} \quad$ - Usuário

$\mathbf{J}\left(i^{*}\right) \quad-$ Conjunto de trechos situados a jusante do usuário $i^{*}$

k - Ponto de captação que sofre interferência na qualidade de suas águas devido a lançamentos, (adimensional)

$\mathbf{K}_{\mathbf{m}, \mathbf{T}}$ - Parâmetro "m" considerado para uma dada temperatura " $T$ "

$\mathbf{K}_{1} \quad$ - Parâmetro de degradação, (1/dia)

$\mathbf{K}_{2}$ - Parâmetro de reaeração, (1/dia)

$\mathbf{K}_{\mathbf{3}} \quad$ - Parâmetro de sedimentação, (1/dia)

$\mathbf{K}_{4} \quad$ - Taxa de demanda de oxigênio do sedimento, $\left(\mathrm{g} / \mathrm{m}^{2}\right.$ dia $)$

K $\mathbf{1 0}$ - Multiplicador de preço unitário para captação, (adimensional)

$\mathbf{K}_{11} \quad$ - Coeficiente de consumo (uso consultivo) para a atividade em questão, ou seja, a relação entre o volume consumido e o volume captado pelo usuário, (adimensional) 
$\mathbf{K}_{12} \quad$ - Percentual do volume de efluentes tratados em relação ao volume total de efluentes produzidos, ou a razão efluente tratada e a vazão efluente bruta, (adimensional)

$\mathbf{K}_{13} \quad$ - Eficiência de redução da carga orgânica (medida em Demanda Bioquímica de Oxigênio - DBO) do tratamento de efluentes do usuário, (adimensional)

$\boldsymbol{k}^{*} \quad-$ Trecho de rio

L L - Demanda bioquímica carbonácea de oxigênio última, $(\mathrm{mg} / \mathrm{L})$

$\mathbf{L}_{\mathbf{t}} \quad$ - Demanda bioquímica de oxigênio em um tempo t, $(\mathrm{mg} / \mathrm{L})$

L $\mathbf{L}_{0} \quad$ - Concentração de DBO no ponto de mistura do efluente com o corpo receptor, $(\mathrm{mg} / \mathrm{L})$

n - Elemento computacional ou sub-trecho

$\mathbf{N}_{1}$ - Concentração de nitrogênio amoniacal, (mg N/L)

$\mathbf{N}_{2} \quad-$ Concentração de nitrito, $(\mathrm{mg} \mathrm{N} / \mathrm{L})$

P - Pressão atmosférica local, (atm.)

p - Poluente

PUB $_{\text {cap }}$ - Preço Unitário Básico para captação, $(\mathrm{R} \$)$

PUB $_{\text {CI }}$ - Preço Unitário Básico para carga inorgânica, (R\$)

PUB $_{\text {cons }}$ - Preço Unitário Básico para consumo, $(\mathrm{R} \$)$

PUB $_{\text {DBo }}$ - Preço Unitário Básico para a variável DBO, $(\mathrm{R} \$)$

PUB $_{\text {DQO }}$ - Preço Unitário Básico para a variável DQO, $(\mathrm{R} \$)$

PUB $_{\mathrm{RS}}$ - Preço Unitário Básico para resíduo sólido, (R\$)

PUF $_{\text {cap }} \quad$ - Preço Unitário Final para captação, (R\$)

PUF $_{\text {CI }}$ - Preço Unitário Final para carga inorgânica, $(\mathrm{R} \$)$

PUF $_{\text {cons }}$ - Preço Unitário Final para consumo, $(\mathrm{R} \$)$

$\mathbf{P U F}_{\text {DBo - }}$ - Preço Unitário Final para a variável DBO, $(\mathrm{R} \$)$

PUF $_{\text {DQO }}$ - Preço Unitário Final para a variável DQO, $(\mathrm{R} \$)$

$\mathbf{P U F}_{\mathbf{R S}} \quad$ - Preço Unitário Final para a variável resíduo sólido, (R\$)

PPU - Preço Público Unitário pelo uso da água seja para captação, consumo e ou diluição de efluentes, $\left(\mathrm{R} \$ / \mathrm{m}^{3}\right)$

Q - Vazão

Qc(x) - Vazão de captação, $\left(\mathrm{m}^{3} / \mathrm{s}\right)$

$\mathbf{Q}_{\text {cap }} \quad$ - Vazão de captação, $\left(\mathrm{m}^{3} / \mathrm{s}\right)$

Qcap $_{\mathbf{m}}$ - Volume da água captada durante um mês, $\left(\mathrm{m}^{3} / \mathrm{mês}\right)$ 
QCI - Vazão de lançamento do efluente para o parâmetro carga inorgânica, $\left(\mathrm{m}^{3} / \mathrm{s}\right)$

Qcons - Vazão de consumo, $\left(\mathrm{m}^{3} / \mathrm{s}\right)$

QDo - Vazão de diluição do poluente no ponto de lançamento do efluente, $\left(\mathrm{m}^{3} / \mathrm{s}\right)$

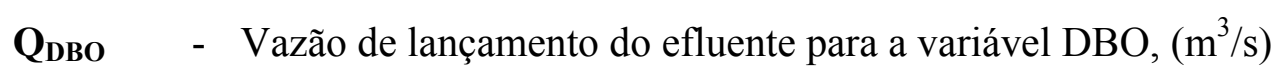

QDc(x) - Vazão de diluição da carga de poluente retirada através de captação, $\left(\mathrm{m}^{3} / \mathrm{s}\right)$

QD(x) - Vazão de diluição do poluente no rio, $\left(\mathrm{m}^{3} / \mathrm{s}\right)$

QDQo - Vazão de lançamento do efluente para a variável DQO, $\left(\mathrm{m}^{3} / \mathrm{s}\right)$

Qe - Vazão de lançamento do efluente no corpo receptor, $\left(\mathrm{m}^{3} / \mathrm{s}\right)$

$\mathbf{Q}_{\mathbf{L}}(\mathbf{x})$ - Vazão de diluição liberada para novas outorgas, $\left(\mathrm{m}^{3} / \mathrm{s}\right)$

$\mathbf{Q}_{\mathbf{L L}}(\mathbf{x})$ - Vazão de diluição liberada por lançamento, $\left(\mathrm{m}^{3} / \mathrm{s}\right)$

Qr(x) - Vazão do corpo receptor, $\left(\mathrm{m}^{3} / \mathrm{s}\right)$

Qm - Vazão média dentro de toda série observada, $\left(\mathrm{m}^{3} / \mathrm{s}\right)$

Qrm - Vazão do rio imediatamente a montante do ponto de lançamento do efluente, $\left(\mathrm{m}^{3} / \mathrm{s}\right)$

QRS - Vazão de lançamento do efluente para a variável resíduo sólido, $\left(\mathrm{m}^{3} / \mathrm{s}\right)$

Q $\quad$ - Quantidade de água realmente utilizada pelo usuário, referente a um trecho de rio, ao longo de um intervalo de tempo, $\left(\mathrm{m}^{3} / \mathrm{s}\right)$

Q $\quad$ - Quantidade de água concedida ao usuário para seu próprio uso, dentro de um intervalo de tempo, $\left(\mathrm{m}^{3} / \mathrm{s}\right)$

$\mathbf{Q}_{7,10} \quad$ - Vazão média mínima de sete dias consecutivos com período de retorno de 10 anos, $\left(\mathrm{m}^{3} / \mathrm{s}\right)$

Q95 - Vazão com garantia de $95 \%$ de permanência dentro de toda a série observada, $\left(\mathrm{m}^{3} / \mathrm{s}\right)$

Q90 - Vazão com garantia de $90 \%$ de permanência dentro de toda a série observada, $\left(\mathrm{m}^{3} / \mathrm{s}\right)$

$\mathbf{r}_{\mathbf{p}, \mathbf{k}^{*}}\left(\mathbf{i}^{*}, \mathbf{t}\right)$ - Impedimento de utilização de água por parte dos outros usuários, para cada trecho $k^{*}$, ao longo do intervalo $\Delta \mathrm{t}$

S - Declividade, $(\mathrm{m} / \mathrm{m})$

Sn - Geração e consumo interno

T - Temperatura da água, $\left({ }^{\circ} \mathrm{K}\right)=\left({ }^{\circ} \mathrm{C}\right)+273,15$

t - Tempo

$\mathbf{t}_{\mathbf{c}} \quad-$ Tempo crítico, (d) 
$\mathbf{T} * \quad-\quad$ Número de intervalo $\Delta \mathrm{t}$ em que o ano pode ser dividido

U - Velocidade média, $(\mathrm{m} / \mathrm{s})$

$\mathbf{u}^{*} \quad-$ Velocidade de cisalhamento, $(\mathrm{m} / \mathrm{s})$

Ve - Volume de captação, $\left(\mathrm{m}^{3} / \mathrm{s}\right)$

VDc(x) - Volume de diluição da carga de poluente retirada através de captação, referente apenas ao lançamento do efluente do usuário-poluidor considerado, $\left(\mathrm{m}^{3} / \mathrm{s}\right)$

VD(x) - Volume de diluição do poluente no corpo receptor, referente apenas ao lançamento do usuário-poluidor considerado, $\left(\mathrm{m}^{3} / \mathrm{s}\right)$

Vs - Velocidade de sedimentação do poluente, $(\mathrm{m} / \mathrm{d})$

$\mathbf{x} \quad-$ Espaço

$\mathbf{x}_{1}, \mathbf{x}_{2}, \ldots$ - Coeficientes multiplicadores

$\mathbf{x}_{\mathbf{f}}$

- Trecho de rio

$\mathbf{y}_{\mathbf{f}} \quad-$ Coeficiente multiplicador

$\mathbf{y}_{1} \quad$ - Coeficiente multiplicador que caracteriza a origem do efluente

$\mathbf{y}_{2} \quad$ - Coeficiente multiplicador que caracteriza a classe do corpo receptor

$\mathbf{y}_{3} \quad$ - Coeficiente multiplicador que caracteriza a sazonalidade

$\alpha \quad$ - Contribuição de cada usuário da bacia para custear o sistema de outorga

$\alpha_{3} \quad$ - Produção de oxigênio por crescimento de algas, (mg O) / (mg A)

$\alpha_{4} \quad$ - Taxa de consumo de oxigênio por respiração por unidade de algas, (mg O / mg A)

$\alpha_{5} \quad$ - Taxa de consumo de oxigênio por oxidação de nitrogênio amoniacal, $\mathrm{NH}_{3}$, $(\mathrm{mg} \mathrm{O}) /(\mathrm{mg} \mathrm{N})$

$\alpha_{6} \quad-\quad$ Taxa de consumo de oxigênio por oxidação de nitrito, $\mathrm{NO}_{2}{ }^{-2},(\mathrm{mg} \mathrm{O}) /(\mathrm{mg}$ N)

$\beta_{1} \quad$ - Coeficiente de oxidação de amônia, (1/dia)

$\beta_{2} \quad-$ Coeficiente de oxidação de nitrito, (1/dia)

$\beta_{*} \quad$ - Quantidade de água outorgada

$\mu \quad$ - Taxa de crescimento de algas, (1/dia)

$\rho \quad$ - Taxa de respiração algal, (1/dia)

$\gamma\left(\mathbf{i}^{*}\right)$ - Cobrança pelo uso efetivo da água para o usuário $i^{*}$

$\theta \quad-$ Coeficiente de temperatura 


\section{RESUMO}

O presente trabalho apresenta-se como um marco inovador na área de gestão de recursos hídricos, já que o mesmo consegue inserir aspectos de qualidade da água para os processos de outorga e cobrança pelo uso da água, de forma articulada a todos os instrumentos da Política Nacional de Recursos Hídricos (Lei 9.433 de 1997), possibilitando a efetiva aplicação da Política e da Resolução ${ }^{\circ} 48$, de 21 de março de 2005, que estabelece critérios gerais para a cobrança pelo uso dos recursos hídricos. Traz também para a Política um novo conceito, o de Justiça Hídrica, ou seja, quem capta água com qualidade superior paga mais do que quem capta água com qualidade inferior, assim como, quem mais polui e prejudica os usuários de jusante, mais paga. Neste trabalho, a variável de decisão do sistema é o volume outorgado e o estudo leva em consideração a capacidade de autodepuração, o enquadramento em classes de uso, o regime de vazão do corpo hídrico, a qualidade da água captada e os prejuízos, em termos de qualidade da água, ocasionados pelos usuários-poluidores aos usuários de jusante. A ferramenta de auxílio aqui oferecida é um Sistema de Suporte a Decisão (SSD), denominado RB, que apresenta: um módulo Interface, um módulo Modelos, constituído pelo modelo de outorga e cobrança pelo uso da água RM1 e pelo modelo de qualidade das águas QUAL2E e, por fim, um módulo Dados, que representa os dados de entrada e saída do sistema. O SSD RB foi aplicado à bacia do rio Jundiaí, afluente do rio Tietê, localizado no Estado de São Paulo. Na aplicação do SSD RB, foi realizada uma análise comparativa para a variação de cenários relativa a Classes de Uso do corpo hídrico, vazões de referência e diferentes valores de cobrança que podem ser utilizados. A aplicação do SSD RB reflete a necessidade de uma articulação sistemática entre os instrumentos da Política Nacional de Recursos Hídricos, apoiada na diretriz de gestão integrada de recursos hídricos, ou seja, existe um único corpo de trabalho (a gestão de recursos hídricos) cujos membros (instrumentos de gestão) só ganham sentido quanto articulados entre si com um mesmo objetivo: a garantia de água de boa qualidade com a quantidade necessária à atual e às futuras gerações. 


\begin{abstract}
The main objective of this study is to develop a set of tools to help with the implementation of water management mechanisms such as the analysis of authorization of water uses (permits) and water charging. An integrated analysis of both water quality and quantity is needed and the decision process must also take into account watershed plans and the designated uses of the water. In this study, the decision variable is the volume of water authorized in each permit. The tool developed in this study is a Decision Support System named RB, based on the QUAL2E model and an water permit and charging simulation system named RM1. The RB system was tested in the Jundiaí watershed, a tributary of the Tietê river located in the State of São Paulo. In this case study, several scenarios with different classification of water bodies, reference flows and water values were tested. The application of the system shows that water management tools must be applied in an integrated manner, mainly to reflect both aspects of water quality and quantity. Water management tools are to be articulated so that the main objective of supplying water with good quality and in an adequate amount is sustainable in the long run.
\end{abstract}




\section{Capítulo 1}

\section{INTRODUÇÃO}

A Política Nacional de Recursos Hídricos, através da Lei 9.433, tem em um de seus objetivos assegurar à atual e às futuras gerações a necessária disponibilidade de águas, em padrões de qualidade adequados aos respectivos usos.

Os instrumentos da Política Nacional de Recursos Hídricos são: os Planos de Recursos Hídricos; o enquadramento dos corpos de água em classes, segundo os usos preponderantes da água; a outorga e a cobrança pelo uso da água; o Sistema Nacional de Informações sobre Recursos Hídricos.

Os Planos de Recursos Hídricos visam orientar e viabilizar a implementação da Política Nacional de Recursos Hídricos e o gerenciamento dos recursos hídricos. São elaborados por Bacia Hidrográfica, por Estado e para o País; são planos de longo prazo, com horizonte de planejamento compatível com o período de implementação de seus programas e projetos.

O enquadramento dos corpos de água em classes permite fazer a junção entre a gestão da qualidade e da quantidade da água, visando assegurar água com qualidade compatível aos usos mais exigentes da bacia.

A outorga pelo uso da água tem como objetivos assegurar o controle quantitativo e qualitativo dos usos da água e o efetivo exercício dos direitos de acesso a água associado a uma garantia. A cobrança está condicionada à outorga e objetiva reconhecer a água como um bem econômico, incentivar a racionalização do uso da água e obter 
recursos financeiros para atendimento das metas estabelecidas nos Planos de Recursos Hídricos. O Sistema de Informações de Recursos Hídricos visa à coleta, o tratamento e o armazenamento de informações sobre recursos hídricos.

Dentro do exposto acima, este trabalho apresenta um Sistema de Suporte a Decisão (SSD), denominado RB. Sistemas de Suporte a Decisão são sistemas computacionais de articulação de dados representados por uma Interface Gráfica, um módulo Modelos e um módulo Dados.

O SSD RB apresenta-se como uma ferramenta de gestão quali-quantitativa para os processos de outorga e cobrança pelo uso da água, que viabiliza a articulação de todos os instrumentos de gestão da Política Nacional de Recursos Hídricos: Plano de Recursos Hídricos, enquadramento dos corpos d'água em suas respectivas classes de uso e Sistema de Informações de Recursos Hídricos. O desenvolvimento do SSD RB foi apoiado na diretriz de gestão sistemática de recursos hídricos, sem dissociação dos aspectos de qualidade e quantidade, significando que os processos de outorga e cobrança pelo uso da água, passam, pioneiramente, a serem tratados sob os aspectos integrados de qualidade e quantidade da água.

Para que os processos de outorga e cobrança pelo uso da água sejam geridos em quantidade e qualidade, existe a necessidade de se considerar de forma articulada o enquadramento em classes de uso, o regime de vazão e a capacidade de autodepuração do corpo hídrico, tudo isto diante do cenário real da bacia hidrográfica. Logo, existe a necessidade de se trabalhar com um modelo de qualidade da água que possibilite a entrada de dados de qualidade e quantidade da água, assim como, existe também a necessidade de se trabalhar com um modelo de outorga e cobrança pelo uso da água.

Assim, para pleno atendimento a gestão dos processos de outorga e cobrança pelo uso da água, nasceu o SSD RB, que integra o modelo de outorga e cobrança pelo uso da água RM1 (RODRIGUES, 2000) e o modelo de qualidade das águas QUAL2E (BROWN e BARNWELL, 1987).

O modelo de outorga e cobrança pelo uso da água RM1 permite que o usuário pague pelo efetivo uso da água, tanto para lançamento como para captação, considerando: a 
capacidade de autodepuração do corpo hídrico; o enquadramento; a vazão do corpo hídrico; a qualidade da água captada; os prejuízos, em termos de qualidade da água, ocasionados pelos usuários-poluidores de montante aos usuários de jusante.

A integração desses modelos proporciona uma maior agilidade no processo de gestão de recursos hídricos, de forma integrada a todos os instrumentos da Política Nacional de Recursos Hídricos. Responde também sobre a implicação da inclusão de novos pontos de captação e lançamento ao longo do corpo receptor, tanto em termos de qualidade e quantidade da água, como em termos de custos de captação e lançamento, viabilizando a alocação racional de recursos hídricos.

A idéia de integração dos modelos RM1 e QUAL2E nasceu a partir do desenvolvimento do modelo RM1, no âmbito do programa de mestrado da autora. No programa de mestrado, o modelo foi aplicado à bacia do rio Jundiaí. Os cálculos foram realizados com auxílio de planilhas de cálculo e do modelo QUAL2E através da interface gráfica oferecida pelo USEPA (1995). No estudo realizado, verificou-se que este procedimento de aplicação do modelo RM1 é muito trabalhoso, demanda uma quantidade grande de tempo, assim como induz a uma margem grande de erros.

Foi sugerido o desenvolvimento de um sistema, em ambiente Windows, de aplicação do modelo RM1, para dar suporte ao planejamento e gerenciamento de recursos hídricos para os processos de outorga e cobrança pelo uso da água. Recomendou-se que o sistema trabalhasse junto com um modelo de qualidade das águas que atendesse ao propósito do estudo, ficou como sugestão o modelo QUAL2E, dado o seu bom atendimento e sua ampla utilização mundial. RODRIGUES (2000).

Para o desenvolvimento do SSD RB foi necessário, primeiramente, a preparação de uma interface gráfica em ambiente Windows para o modelo QUAL2E, denominada QUAL2R (RODRIGUES e PORTO, 2003). O modelo QUAL2E está em linguagem de programação ANSI FORTRAN 77, já a interface QUAL2R (Versão 1.00) e o SSD RB (Versão 1.00) foram desenvolvidos em linguagem de programação VISUAL BASIC 6. 
O modelo de simulação de qualidade da água Stream Water Quality Model - QUAL2E, distribuído pela US Environmental Protection Agency - USEPA, é um modelo unidimensional de qualidade das águas superficiais que permite simular até 15 variáveis de qualidade das águas. Este modelo quantifica a concentração do poluente ao longo do corpo receptor mediante um cenário global de lançamentos e captações (BROWN e BARNWELL, 1987).

O modelo RM1 determina por lançamento e poluente: a variação longitudinal da vazão de diluição de outorga; a vazão liberada por lançamento; o volume de diluição da carga de poluente do usuário de montante retirada através de captações pelo usuário de jusante. Através do modelo RM1 é possível também determinar, diante de um cenário conjunto de cargas lançadas no corpo hídrico, a vazão que vai sendo liberada no sistema para novas outorgas à medida que a decomposição se processa. Todas as determinações do modelo RM1 são realizadas considerando o processo de autodepuração, o enquadramento e o regime de vazão do corpo hídrico (RODRIGUES, 2000).

Essas determinações são possíveis através da separação pelo modelo RM1 de quanto efetivamente cada usuário-poluidor contribui em carga de poluente ao longo do corpo receptor, diante de um cenário conjunto de concentrações fornecido por um modelo unidimensional de qualidade das águas como, por exemplo, o modelo QUAL2E. Logo, o modelo RM1 oferece a possibilidade de se quantificar a vazão de diluição e a vazão liberada ao longo do rio, para cada lançamento e poluente, considerando o processo de autodepuração, o enquadramento e o regime de vazão do corpo hídrico (RODRIGUES, 2000).

A quantificação pelo modelo RM1 da carga de poluente retirada do rio através de pontos de captação, referente a cada usuário-poluidor de montante, permitiu, a partir deste trabalho, que o custo da vazão de diluição da carga de poluente retirada do rio fosse repassado ao respectivo usuário-poluidor de montante e subtraído do custo da respectiva captação. Logo, quanto pior a qualidade da água captada, menor o custo para a captação, assim como, para lançamento, quanto maiores os danos provocados aos usuários de jusante, maior o custo de lançamento do respectivo efluente. 
No modelo RM1 o usuário de recursos hídricos paga pelo seu uso efetivo, tanto para lançamento de efluentes como para captação, considerando: a qualidade da água captada; os prejuízos, em termos de qualidade da água, ocasionados pelos usuáriospoluidores aos usuários de jusante, inserindo dessa forma um novo conceito no processo de gestão de recursos hídricos, o de Justiça Hídrica.

Como o modelo RM1 leva em consideração a capacidade assimilativa do rio, caso o ponto de captação do usuário de jusante não sofra mais interferência dos lançamentos de montante, o custo de captação não sofre nenhum amortecimento, situação esta que ocorre também com o ponto de captação localizado mais próximo da cabeceira.

O SSD RB visa auxiliar e orientar os decisores no processo de gestão de recursos hídricos, na inserção de dados de forma eficiente, assim como fornecer uma saída gráfica que permita uma visualização dos dados de forma didática e flexível. O SSD RB trabalha com cenários diversificados de vazão, dados hidráulicos, classe de uso do rio, custos unitários, parâmetros e coeficientes, condições de cabeceira, fluxo incremental (poluição difusa) e condições iniciais do rio. A saída gráfica oferecida pelo sistema permite que o usuário realize análises comparativas entre os resultados obtidos através dos cenários simulados. Valores "default" são fornecidos para auxiliar o usuário no processo de entrada de dados.

Os cálculos efetuados pelo SSD RB para cenários diversificados de vazão, diante de um mesmo cenário de lançamentos e captações de um rio, propiciam uma avaliação da qualidade das águas para os mais diversos regimes que o rio pode ser submetido, assim como uma análise qualitativa e quantitativa de lançamentos e captações para os processos de outorga e cobrança. Cenários de enquadramento e custos unitários auxiliam também no processo de gestão da bacia hidrográfica. Já a diversificação de cenários de dados hidráulicos, parâmetros, condições de cabeceira, fluxo incremental e condição inicial do rio podem auxiliar no processo de calibração do sistema.

Na modelagem do SSD RB ocorre a integração dos modelos QUAL2E e RM1, visando à simulação de rios e/ou trechos de rios com cenários de vazão distintos, que podem ser provenientes de dados obtidos através da série histórica de postos fluviométricos e/ou pluviométricos, ou através de vazões liberadas por reservatórios. 
Assim, o SSD RB, através do modelo RM1, integra, aos processos de análise de outorga e cobrança pelo uso da água, aspectos de qualidade da água articulados aos instrumentos de gestão de recursos hídricos, tanto no que se refere à outorga de lançamento como às outorgas de usos quantitativos, tratando ambas a partir da mesma variável de decisão, ou seja, volume outorgado.

O SSD RB foi aplicado à bacia do rio Jundiaí, afluente do rio Tietê, localizado no Estado de São Paulo. Na aplicação do SSD RB foi realizada uma análise comparativa para a variação de cenários de Classes de Uso, vazões de referência do corpo hídrico e valores de cobrança. 


\subsection{Objetivos}

\subsubsection{Geral}

- Oferecer uma ferramenta de auxílio para subsidiar a gestão quali-quantitativa dos processos de outorga e cobrança pelo uso da água, possibilitando a articulação com os demais instrumentos de gestão da Política Nacional de Recursos Hídricos: Plano de Recursos Hídricos, enquadramento dos corpos d'água em suas respectivas classes de uso e Sistema de Informações de Recursos Hídricos. Introduzir um novo conceito no processo de gestão de recursos hídricos, o de Justiça Hídrica.

\subsubsection{Específicos}

- Considerar para os processos de outorga e cobrança pelo uso da água o enquadramento, as características hidráulicas, o regime de vazão e a capacidade de autodepuração do corpo hídrico, de forma articulada aos instrumentos da Política Nacional de Recursos Hídricos;

- Integrar ao processo de análise de outorga aspectos de qualidade da água, tanto no que se refere à outorga de lançamento como às outorgas de usos quantitativos, tratando as mesmas a partir da variável de decisão, ou seja, volume outorgado;

- Fazer com que os usuários que captam água mais limpa no rio paguem mais que os usuários que captam água com qualidade inferior, assim como lançamentos de montante sejam penalizados financeira e proporcionalmente pelos danos causados aos usuários de jusante, introduzindo um novo conceito na área de gestão de recursos hídricos, o de Justiça Hídrica;

- Para atendimento dos objetivos acima, oferecer subsídios para o processo de integração dos modelos RM1 e QUAL2E, modelando o sistema de forma a prover medidas de contorno para suas limitações, viabilizando o funcionamento do sistema como um todo; 
- Desenvolver um Sistema de Suporte a Decisão, denominado RB. O SSD RB é constituído por um módulo Interface, um módulo Modelos que é representado pelos modelos RM1 e QUAL2E e, por fim, um módulo Dados que representa os dados de entrada e saída do sistema;

- Aplicar o SSD RB à bacia do rio Jundiaí, afluente do rio Tietê, localizado no Estado de São Paulo, para três cenários:

a) No Cenário 1 fixar a vazão de referência para o regime $Q_{95}$ e variar o enquadramento para as Classes 2 e 4 ;

b) No Cenário 2 fixar o enquadramento na Classe 2 e variar a vazão de referência para os regimes $\mathrm{Q}_{7,10}, \mathrm{Q}_{95}, \mathrm{Q}_{90} \mathrm{e} \mathrm{Qm}$;

c) No Cenário 3 fixar o regime de vazão em Q95 e o enquadramento para a Classe 2, variar valores de cobrança.

Adotar os regimes de vazão $\mathrm{Q}_{7,10}, \mathrm{Q}_{95}, \mathrm{Q}_{90}$ e Qm com o objetivo de partir de um valor de vazão mais restritivo para um menos restritivo, respectivamente; possibilitando, dessa forma, analisar a interferência do valor de vazão adotada na qualidade da água e, sobretudo, nos processos de outorga e cobrança pelo uso da água.

$\mathrm{Q}_{7,10}$ - Vazão média mínima de sete dias consecutivos com período de retorno de 10 anos.

Q95 - Vazão com garantia de $95 \%$ de permanência dentro da série histórica de dados observada.

Q90 - Vazão com garantia de $90 \%$ de permanência dentro da série histórica de dados observada.

Qm - Vazão média dentro da série histórica de dados observada. 


\section{Capítulo 2}

\section{REVISÃO BIBLIOGRÁFICA}

\subsection{A Política Nacional de Recursos Hídricos}

A Política Nacional de Recursos Hídricos, através da Lei 9.433, de 8 de janeiro de 1997, institui, no Art. 5º, os instrumentos de gestão de recursos hídricos:

I - os Planos de Recursos Hídricos;

II - o enquadramento dos corpos de água em classes, segundo os usos preponderantes da água;

III - a outorga dos direitos de uso de recursos hídricos;

IV - a cobrança pelo uso de recursos hídricos;

V - o Sistema de Informações sobre Recursos Hídricos.

De acordo com a Lei 9.433, as decisões sobre uso dos rios em todo o país serão tomadas, dentro do contexto de bacia hidrográfica, pelos comitês de bacias. Os Comitês de Bacia Hidrográfica - $\mathrm{CBH}$ são órgãos colegiados descentralizados por bacias hidrográficas, sendo compostos por representantes do governo, municípios, usuários da água e sociedade civil. Cada Comitê de Bacia Hidrográfica terá uma Agência de Água que exercerá a função de secretaria executiva do respectivo ou respectivos Comitês de Bacia Hidrográfica. 
A decisão sobre as prioridades para outorga de direitos de uso de recursos hídricos de uma bacia hidrográfica é estabelecida no âmbito do Comitê. Estas prioridades farão parte do Plano de Recursos Hídricos da bacia. O estabelecimento de prioridades condiciona o enquadramento do corpo de água em Classes de Uso. A Classe de Uso está associada a vários usos que aceitam valores de qualidade da água estabelecidos na forma de padrões (CONAMA n ${ }^{\circ}$ 357, de 17 de março de 2005). Padrões são valores estabelecidos por lei que, com base no respaldo científico, garantem a segurança dos usos estabelecidos.

Na Lei 9.433, as atribuições previstas para os Comitês de Bacias Hidrográficas, dentre outras, são:

- promover o debate das questões relacionadas a recursos hídricos e articular a atuação das entidades intervenientes;

- arbitrar, em primeira instância administrativa, os conflitos relacionados aos recursos hídricos;

- aprovar o Plano de Recursos Hídricos da bacia;

- acompanhar a execução do Plano de Recursos Hídricos da bacia e sugerir as providências necessárias ao cumprimento de suas metas;

- estabelecer os mecanismos de cobrança pelo uso de recursos hídricos e sugerir os valores a serem cobrados.

Como secretaria executiva, cabe também às Agências de Água, dentro de sua área de atuação, elaborar o Plano de Recursos Hídricos para a apreciação do respectivo Comitê de Bacia Hidrográfica, assim como propor ao Comitê o enquadramento dos corpos de água nas classes de uso. São também atribuições das Agências de Água:

- manter o balanço atualizado da disponibilidade de recursos hídricos; efetuar a cobrança pelo uso de recursos hídricos;

- administrar os recursos arrecadados com a cobrança;

- gerir o Sistema de Informações sobre Recursos Hídricos;

- celebrar convênios e contratar financiamentos e serviços para a execução de suas competências; 
- elaborar a sua proposta orçamentária e submetê-la à apreciação do respectivo ou respectivos Comitês de Bacia Hidrográfica;

- promover os estudos necessários para a gestão dos recursos hídricos em sua área de atuação.

\subsubsection{Os Planos de Recursos Hídricos}

Cabe ao Comitê de Bacia Hidrográfica, em sua área de atuação, aprovar o Plano de Recursos Hídricos e acompanhar sua execução, assim como, sugerir providências necessárias ao cumprimento de suas metas. Logo, estando os Planos de Recursos Hídricos apoiados nas decisões dos Comitês e sendo estes planos diretores que visam a fundamentar e orientar a implementação da Política Nacional de Recursos Hídricos e o gerenciamento de recursos hídricos, observa-se que, legalmente, a Política Nacional de Recursos Hídricos é de fato descentralizada e participativa, considerando que os Comitês são compostos por representantes do governo, municípios, usuários da água e sociedade civil.

A Lei 9.433 estabelece que os Planos de Recursos Hídricos são planos de longo prazo, com horizonte de planejamento compatível com o período de implantação de seus programas e projetos e terão o seguinte conteúdo mínimo:

- diagnóstico da situação atual dos recursos hídricos;

- análise de alternativas de crescimento demográfico, de evolução de atividades produtivas e de modificações dos padrões de ocupação do solo;

- balanço entre disponibilidades e demandas futuras dos recursos hídricos, em quantidade e qualidade, com identificação dos conflitos potenciais;

- metas de racionalização de uso, aumento da quantidade e melhoria da qualidade dos recursos hídricos disponíveis;

- medidas a serem tomadas, programas a serem desenvolvidos e projetos a serem implementados, para o atendimento das metas previstas;

- prioridades para outorga de direitos de uso de recursos hídricos;

- diretrizes e critérios para a cobrança pelo uso dos recursos hídricos; 
- propostas para a criação de áreas sujeitas a restrição de uso, com vista à proteção dos recursos hídricos.

\subsubsection{O Enquadramento e a Resolução CONAMA nº 357}

O enquadramento dos corpos de água em classes, segundo os usos preponderantes da água, possibilita a gestão sistemática dos recursos hídricos, sem dissociação dos aspectos de qualidade e quantidade, já que a concentração de poluente está diretamente relacionada à vazão do corpo hídrico. A gestão dos recursos hídricos em quantidade e qualidade está condicionada à outorga de uso da água para captação e lançamento de efluentes.

Logo, para concessão ou não de uma outorga de lançamento ou captação, deve ser realizada uma análise do possível impacto aos usos prioritários estabelecidos para a bacia, considerando a vazão do corpo hídrico, de forma a garantir os objetivos do enquadramento, estabelecidos no Art. $9^{\circ}$, da Lei 9.433:

- assegurar às águas qualidade compatível com os usos mais exigentes que forem destinadas;

- diminuir os custos de combate à poluição das águas, mediante ações preventivas permanentes.

O enquadramento de um corpo hídrico não representa, necessariamente, a qualidade que ele se encontra, mas sim uma possível estratégia de planejamento para atendimento às metas de médio e longo prazos, estabelecidas nos Planos de Recursos Hídricos. Segundo PORTO (2002): “... Na qualidade de instrumento de planejamento, ele trabalha com a visão futura da bacia e permite que se defina a tática a ser utilizada nesse caminho rumo à situação desejada ...”.

A Resolução CONAMA n ${ }^{\circ}$ 357, de 17/03/2005, dispõe sobre a classificação dos corpos de água e diretrizes ambientais para o seu enquadramento, bem com estabelece as condições e padrões de lançamento de efluentes. 
O Art. $2^{\circ}$, da referida Resolução, adota a seguinte definição para enquadramento: “estabelecimento da meta ou objetivo de qualidade da água (classe) a ser, obrigatoriamente, alcançado ou mantido em um segmento do corpo de água, de acordo com os usos preponderantes, ao longo do tempo".

Logo, a partir desta Resolução, o enquadramento dos corpos de água deve estar baseado não necessariamente no seu estado atual, mas também em metas de escalonamento visando o atendimento progressivo aos usos preponderantes da bacia, atuais ou futuros, o que a torna racional e coerente.

Do Capítulo V, das diretrizes ambientais para o enquadramento, no Art. 38 e seus incisos, ficam estabelecidos:

Art. 38. O enquadramento dos corpos de água dar-se-á de acordo com as normas e procedimentos definidos pelo Conselho Nacional de Recursos Hídricos - CNRH e Conselhos Estaduais de Recursos Hídricos.

$\S 1^{\circ} \mathrm{O}$ enquadramento do corpo hídrico será definido pelos usos preponderantes mais restritivos da água, atuais ou pretendidos.

$\S 2^{\circ}$ Nas bacias hidrográficas em que a condição de qualidade dos corpos de água esteja em desacordo com os usos preponderantes pretendidos, deverão ser estabelecidas metas obrigatórias, intermediárias e final, de melhoria da qualidade da água para efetivação dos respectivos enquadramento, excetuados nos parâmetros que excedam aos limites devido às condições naturais.

$\S 3^{\circ}$ As ações de gestão referentes ao uso dos recursos hídricos, tais como a outorga e cobrança pelo uso da água, ou referentes à gestão ambiental, como o licenciamento, termos de ajustamento de conduta e o controle da poluição, deverão basear-se nas metas progressivas intermediárias e final aprovadas pelo órgão competente para a respectiva bacia hidrográfica ou corpo hídrico específico.

$\S 4^{\circ}$ As metas progressivas obrigatórias, intermediárias e final, deverão ser atingidas em regime de vazão de referência, excetuados os casos de baías de águas salinas ou 
salobras, ou outros corpos hídricos onde não seja aplicável a vazão de referência, para os quais deverão ser elaborados estudos específicos sobre a dispersão e assimilação de poluentes no meio hídrico.

$\S 5^{\circ}$ Em corpos de água intermitentes ou com regime de vazão que apresente diferença sazonal significativa, as metas progressivas obrigatórias poderão variar ao longo do ano.

$\S 6^{\circ}$ Em corpos de água utilizados por populações para seu abastecimento, o enquadramento e o licenciamento ambiental de atividades a montante preservarão, obrigatoriamente, a condições de consumo.

A Resolução considera, assim como o art. $9^{\circ}$, da Lei 9.433, que o enquadramento deve assegurar às águas qualidade compatível com os usos mais exigentes a que foram destinadas.

Do Capítulo IV, das condições e padrões de lançamento de efluentes, nos artigos 24 e 28, ficam estabelecidos:

Art. 24. Os efluentes de qualquer fonte poluidora somente poderão ser lançados, direta ou indiretamente, nos corpos de água, após o devido tratamento e desde que obedeçam às condições, padrões e exigências dispostos nesta Resolução e em outras normas aplicáveis.

Art. 28. Os efluentes não poderão conferir ao corpo de água características em desacordo com as metas obrigatórias progressivas, intermediárias e final, do seu enquadramento.

A Resolução também considera a necessidade de se criar instrumentos para avaliar a evolução da qualidade das águas, em relação às classes estabelecidas no enquadramento, de forma a facilitar a fixação e controle de metas, visando atingir gradativamente os objetivos propostos.

$\mathrm{O}$ controle da qualidade das águas, associado ao enquadramento $\mathrm{e}$ as metas estabelecidas nos Planos de Recursos Hídricos, vai de encontro a proposta deste 
trabalho, que oferece uma ferramenta, SSD RB, que insere, de forma inovadora, aspectos de qualidade para os processos de outorga e cobrança pelo uso da água, visando a articulação de todos os instrumentos da Política Nacional de Recurso Hídricos.

A Resolução CONAMA n 357 representa um grande avanço na área de gestão de recursos hídricos, já que a mesma consegue promover no plano legislativo a conciliação dos instrumentos de gestão, principalmente, no que diz respeito ao enquadramento, metas e objetivos, e lançamentos.

Segundo PORTO: “A utilização de esquemas de classificação dos corpos de água permite uma melhor explicitação da relação entre usos da água e objetivos de qualidade pretendidos. É muito comum que os objetivos de qualidade da água sejam expressos ou agrupados em Classes de Uso. Permitem assim que sejam definidas estratégias comuns para usos com objetivos de qualidade semelhantes. A classificação dos corpos de água é a combinação dos instrumentos objetivos de qualidade e padrões ambientais, ou critérios de qualidade da água. Nesse caso, quando se aplicam esquemas de classificação dos corpos de água, os padrões ambientais ou critérios de qualidade são definidos para cada classe de uso".

HAASE e SILVA (2003) desenvolveram um trabalho que mostra o processo de enquadramento das águas na bacia hidrográfica do Rio dos Sinos (RS), através da atuação conjunta entre o comitê de bacia, o órgão estadual ambiental e a universidade regional, envolvendo ampla participação da sociedade. Segundo as autoras, a metodologia de consulta à sociedade, através dos representantes por categoria, fortaleceu a representatividade e ampliou o leque de segmentos envolvidos, mas que apesar deste avanço, o exercício de representatividade ainda é um problema a ser equacionado, assim como a participação da sociedade, mesmo que ainda incipiente, é fundamental na formulação de políticas públicas.

COSTA et al (2004) apresentaram uma proposta de enquadramento dos corpos d'água da Bacia do São Francisco. No estudo, foi proposto o enquadramento de 96 trechos de corpos d'água federais e estaduais, assim como recomendações para a gestão da qualidade da água na bacia. Segundo os autores "sugere-se que seja elaborado um plano 
de efetivação de enquadramento da Bacia do São Francisco, estabelecendo as medidas e prazos necessários. Este plano de efetivação deverá estar em conformidade com os demais programas de investimento elaborados no âmbito do Plano de Bacia”.

\subsubsection{Outorga pelo uso da água}

$\mathrm{O}$ instrumento de gestão outorga pelo uso da água assegura o controle qualitativo e quantitativo dos usos da água e o efetivo exercício dos direitos de acesso a água associado a uma garantia. Para tanto deverá considerar o enquadramento em classes de uso e a vazão do corpo hídrico. A análise de concessão de outorga também deverá considerar o impacto do lançamento ou captação no corpo hídrico, diante do cenário real da bacia hidrográfica, e o atendimento às metas estabelecidas nos Planos de Recursos Hídricos, sobretudo, para as prioridades de uso estabelecidas pelo Comitê.

Da outorga de direitos de usos de recursos hídricos, os artigos 11, 12 e 13, da Lei 9.433, estabelecem:

Art. 11. O regime de outorga de direito de uso de recursos hídricos tem como objetivos assegurar o controle quantitativo e qualitativo dos usos da água e o efetivo exercício dos direitos de acesso à água.

Nos incisos I e II do Art. 12, ficam estabelecidos que estão sujeitos à outorga pelo Poder Público os direitos dos seguintes usos de recursos hídricos:

I - derivação ou captação de parcela da água existente em um corpo de água para consumo final, inclusive abastecimento público ou insumo de processo produtivo; III - lançamento em corpo de água de esgotos e demais resíduos líquidos ou gasosos, tratados ou não, com o fim de sua diluição, transporte ou disposição final.

Art. 13. Toda outorga estará condicionada às prioridades de uso estabelecidas nos Planos de Recursos Hídricos e deverá respeitar a classe em que o corpo de água estiver enquadrado e a manutenção de condições adequadas ao transporte aquaviário, quando for o caso. 
No Art. 12, inciso 1, da Resolução n⿳ำ 16, de 08 de maio de 2001, do Conselho Nacional de Recursos Hídricos (CNRH), foi estabelecido:

"As vazões e os volumes outorgados poderão ficar indisponíveis, total ou parcialmente, para outros usos no corpo de água, considerando o balanço hídrico e a capacidade de autodepuração para o caso de diluição de efluentes".

Com o exposto acima, para a efetiva aplicação da Lei 9.433 e da Resolução ${ }^{\circ} 16$ do CNRH, fica clara a importância de se considerar, para os processos de outorga e cobrança pelo uso da água, o regime de vazão, o enquadramento e a capacidade de autodepuração do corpo hídrico.

\section{Metodologias de outorga}

A metodologia apresentada por KELMAN (1997) sugere que a vazão de diluição de um poluente degradável sofre decaimento ao longo do eixo principal, devido à capacidade de autodepuração do corpo receptor. Esta capacidade é representada nesta metodologia pela sugestão do uso de um coeficiente qualitativo $\left(\mathrm{a}_{2}\right)$ para cada trecho de rio que é menor do que a unidade, e multiplica a vazão de diluição requerida pelo sistema no ponto de lançamento do efluente.

Um usuário que lança efluente num curso d'água "se apropria" de uma certa quantidade de água $\left(\mathrm{Q}_{\mathrm{D}}\right)$ para diluir o poluente presente no mesmo, logo:

$$
Q_{D 0}=C e \cdot \frac{Q e}{C p^{*}}
$$

Onde:

$\mathrm{Q}_{\mathrm{D} 0}=$ vazão de diluição do poluente no ponto de lançamento do efluente, $\left(\mathrm{m}^{3} / \mathrm{s}\right)$;

$\mathrm{Qe}=$ vazão de lançamento do efluente no corpo receptor, $\left(\mathrm{m}^{3} / \mathrm{s}\right)$;

$\mathrm{Ce}=$ concentração do poluente no efluente, $(\mathrm{mg} / \mathrm{L})$; 
$\mathrm{Cp}^{*}=$ concentração máxima permissível do poluente no corpo receptor, que poderá resultar do enquadramento do corpo hídrico em classe de uso ou de um plano de recuperação da bacia, $(\mathrm{mg} / \mathrm{L})$.

A quantidade de água utilizada por um usuário da bacia, para cada trecho de rio, pode ser representada pela seguinte formulação:

$$
Q_{T}=a_{1} \cdot Q_{1}+a_{2} \cdot Q_{D 0}
$$

Onde:

$\mathrm{Q}_{\mathrm{T}}=$ quantidade de água realmente utilizada pelo usuário, referente a um trecho de rio, ao longo de um intervalo de tempo, $\left(\mathrm{m}^{3} / \mathrm{s}\right)$;

$\mathrm{a}_{1}=$ coeficiente de utilização quantitativo, ou seja, este coeficiente representa a quantidade de água realmente utilizada pelo usuário, (adimensional);

$\mathrm{Q}_{1}=$ quantidade de água concedida ao usuário para seu próprio uso, dentro de um intervalo de tempo, $\left(\mathrm{m}^{3} / \mathrm{s}\right)$;

$\mathrm{a}_{2}=$ coeficiente qualitativo que representa o processo de autodepuração do poluente no sistema, (adimensional).

Se for adotada a convenção de uso puramente quantitativo, tem-se:

$\mathrm{Q}_{\mathrm{D} 0}=0, \log \mathrm{O}$

$$
Q_{T}=a_{1} \cdot Q_{1}
$$

Segundo KELMAN (1997), ao examinar um pedido de outorga de candidato a usuário, seja para captar uma quantidade de água ou para diluir uma carga poluente, para cada tipo de poluente, a autoridade pública deverá: 
- identificar o conjunto de usuários formado pelo trecho de captação ou de diluição, e por todos os trechos de jusante;

- estimar o coeficiente de utilização quantitativo, $\mathrm{a}_{1}$;

- estimar a quantidade de água necessária para a diluição de cada tipo de poluente;

- estimar o coeficiente de utilização qualitativo $\mathrm{a}_{2}$, para todos os trechos de rio que se localizam a jusante;

- conceder a outorga, caso o limite superior de vazão liberada para outorga, para cada trecho de rio, não seja ultrapassado pelo somatório de todos dos usos consuntivos.

Na metodologia de KELMAN fica proposto: “É necessário manter uma contabilidade para cada tipo de agente poluidor porque o mesmo metro cúbico que serve para diluir DBO, serve também para diluir, por exemplo, nitrogênio."

Todas as proposições acima são levadas em consideração pelo modelo RM1 RODRIGUES (2000) e pelo SSD RB desenvolvido neste trabalho.

RODRIGUES (2000) desenvolveu um modelo de outorga e cobrança pelo uso da água, denominado RM1, que foi aplicado na bacia do rio Jundiaí, no Estado de São Paulo. Tendo como diferença que, neste modelo, o usuário da água paga pelo uso efetivo da água, tanto para lançamento como para captação, considerando: a capacidade de autodepuração do corpo hídrico; a Classe de Uso; a vazão do corpo hídrico; a qualidade da água captada; os prejuízos, em termos de qualidade da água, ocasionados pelos usuários-poluidores de montante aos usuários de jusante.

\subsubsection{Cobrança pelo uso da água}

Da cobrança dos usos de recursos hídricos os artigos 19, 20 e 22, da Lei 9.433, estabelecem:

Art. 19. A cobrança pelo uso de recursos hídricos objetiva:

I - reconhecer a água como bem econômico e dar ao usuário uma indicação de seu real valor;

II - incentivar a racionalização do uso da água; 
III - obter recursos financeiros para o financiamento dos programas e intervenções contemplados nos planos de recursos hídricos.

Art. 20. Serão cobrados os usos de recursos hídricos sujeitos à outorga, nos termos do artigo 12 desta lei.

Art. 22. Os valores arrecadados com a cobrança pelo uso de recursos hídricos serão aplicados prioritariamente na bacia hidrográfica em que foram gerados e serão utilizados:

I - no financiamento de estudos, programas, projetos e obras incluídos nos Planos de Recursos Hídricos;

II - no pagamento de despesas de implantação e custeio administrativo dos órgãos e entidades integrantes do Sistema Nacional de Gerenciamento de Recursos Hídricos.

O fato do artigo 22 estabelecer que os recursos da cobrança sejam aplicados prioritariamente na bacia em que foram arrecadadas não garante a sua efetiva aplicação na bacia, o que levou a elaboração e aprovação do Projeto de Lei, PLS 240/02, em outubro de 2004, para garantir a efetiva gestão descentralizada dos recursos hídricos. O Projeto de Lei PLS 240/02 estabelece que os valores arrecadados com a cobrança pelo uso de recursos hídricos e com a aplicação de multas na bacia em que foram gerados sejam aplicados integralmente na mesma bacia.

A Resolução $\mathrm{n}^{\circ} 48$ estabelece critérios gerais para a cobrança pelo uso dos recursos hídricos. No art. 3 e no inciso I, ficam estabelecidos:

Art. $3^{\circ}$. A cobrança deverá estar compatibilizada e integrada com os demais instrumentos de política de recursos hídricos.

$\S 1^{\circ}$. A cobrança pelo uso dos recursos hídricos deverá ser implementada considerando as informações advindas dos demais instrumentos da Política e os programas e projetos de forma integra.

Como observado, o presente trabalho, atende de forma inovadora, tanto a Resolução $\mathrm{n}^{\circ}$ 48 como a Resolução n ${ }^{\circ} 357$, através do oferecimento de um instrumento, SSD RB, que integra aos processos de outorga e cobrança aspectos de qualidade da água de forma articulada e integrada a todos os instrumentos da Política Nacional de Recursos Hídricos. 
Ressalte-se aqui a importância das referidas resoluções também adotarem o conceito de Justiça Hídrica, conforme criado de forma inovadora no presente trabalho, ou seja, quem capta água com qualidade superior paga mais do que quem capta água com qualidade inferior, assim como, quem mais polui e prejudica os usuários de jusante, mais paga, tornando o sistema de gestão muito mais justo e racional.

A cobrança pelo uso da água é ainda um instrumento que promove o equilíbrio da qualidade de vida dos habitantes da bacia hidrográfica. Dar valor econômico à água é preservar a vida, pois a cobrança permite investir, entre outras coisas, em saneamento básico, agindo de forma econômica em saúde preventiva, reduzindo drasticamente os índices de mortalidade infantil e melhorando as condições ambientais para preservação de diversidade nos diversos ecossistemas das bacias hidrográficas. CONEJO (2000).

Segundo THAME (2000): "No México, quando se iniciou a cobrança pelo uso da água, metade dos recursos arrecadados advinha da cobrança de quem capta, a outra metade daqueles que poluem a água. Nos anos seguintes, a proporção foi mudando. Diminuíram os valores cobrados de quem captava, e aumentaram os de quem poluía. Hoje, quase $90 \%$ dos recursos arrecadados advêm de quem polui, e só $10 \%$ de quem capta água”.

Segundo THAME (2000): "É exatamente neste ponto que fica claro o caráter direcionador da lei de cobrança pelo uso da água: não é um simples instrumento arrecadatório. É um instrumento de gestão. Melhor do que cobrar de quem polui, para investir na reversão da degradação por ele causada, é induzir quem polui a deixar de fazê-lo".

SANTOS e KELMAN (2003) analisaram as experiências de cobrança pelo uso da água em quatro países europeus (França, Alemanha, Holanda e Inglaterra e País de Gales) e, também, a recente experiência brasileira, com foco na proposta de cobrança para o Estado de São Paulo e na cobrança implantada no estado do Ceará e na Bacia do Paraíba do Sul. Segundo os autores: “... nas experiências analisadas, observou-se que a cobrança ainda é estabelecida em níveis baixos em relação aos custos de redução do uso, tem ocorrido, de fato, uma redução a um uso mais racional e sustentável dos recursos hídricos". 
Segundo CONEJO (2000): “A cobrança pelo uso da água é uma dessas práticas, variando de país para país (Ex: Alemanha, Austrália, Bélgica, México, Portugal) e muitas vezes regionalmente, atendendo peculiaridades e culturas regionais e locais diferenciadas. Assim, os modelos de cobrança e de gestão institucional existentes são os mais variados, motivo pelo qual fica difícil a comparação entre eles e a transposição de experiências para outras regiões".

Segundo MACRIS (2000): “É necessário, pois, que se faça uma nova abordagem sobre o uso da água, para incluir não só aspectos sociais e ecológicos como também econômicos, a fim de tornar viáveis projetos de exploração de recursos hídricos, diminuir os custos de tratamento e proteger as bacias hidrográficas, preservando um bem precioso".

Segundo AZEVEDO, BALTAR e FREITAS: "Em 1997, a Lei das Águas do Brasil estabeleceu, entre seus fundamentos, que a água é um recurso natural limitado dotado de valor econômico. Essa percepção, que tomou corpo nas últimas décadas, vem provocando uma profunda mudança na forma como a sociedade vê e utiliza seus recursos hídricos. Por outro lado, a experiência internacional demonstra a importância da cobrança pelo uso da água como instrumento para assegurar a sustentabilidade dos sistemas de recursos hídricos por meio da operação e manutenção adequadas e, também, promover a alocação eficiente deste precioso recurso, sobretudo em regiões em que sua escassez relativa lhe confere um significativo e crescente valor econômico".

Segundo GARRIDO (2000): “O problema não deve ser abordado sem a necessária conexão com o conceito de desenvolvimento, pois o setor de planejamento e gestão dos recursos hídricos existe para, induzindo os usuários a uma utilização racional da água, dar sua contribuição para o crescimento da sociedade, como ponto de passagem essencial para o alcance de seu bem-estar. Por essa razão, a racionalidade da intervenção do setor público na alocação da água de mananciais e, por extensão, a própria cobrança pelo uso da água, devem ser analisadas à luz de programas de desenvolvimento". 


\section{Metodologias de cobrança}

Diversas metodologias foram elaboradas visando à aplicação da cobrança pelo uso da água. Muitas dessas metodologias se afastam da realidade física do processo e estabelecem valores unitários para a cobrança de captação e lançamento, numa tentativa de se aproximar da física do processo, são estabelecidos coeficientes geralmente distantes da realidade. O uso dessas metodologias, muitas vezes, pode não representar a contento a alocação eficiente dos recursos hídricos.

Segundo GARRIDO (2000): “... no que concerne à cobrança, a questão relativa ao quantum ainda é algo objeto de propostas as mais diversificadas, sem um direcionamento - pelo menos no que tange a princípios de cálculo - que conduza a um mínimo de uniformidade de critérios, para que a diversidade dos resultados seja resultado apenas das especificidades de cada região ou bacia, ou ainda rio, lago ou aqüífero, do país. Em outras palavras, a diversidade correrá por conta das naturais diferenças entre os mercados da água bruta, e não pela existência de tantas metodologias de cobrança".

Segundo PORTO (2002): “A lei federal prevê a cobrança pelo uso da água sempre pelo volume utilizado, quer para lançamentos, quer para captações. Esta é a abordagem correta, pois uniformiza a unidade a ser cobrada. É um sistema de mais difícil implantação, mas é mais fácil para a gestão da bacia, na medida em que o balanço disponibilidade - demanda pode ser feito diretamente. Se o sistema for transparente para o usuário, todos saberão que grandes volumes de água são utilizados para fins ‘inúteis' de redução das concentrações, o que facilita a negociação entre usuários. A cobrança por carga poluidora, por exemplo, $\mathrm{KgDBO} /$ dia, não permite a mesma transparência. É mais fácil para estabelecer o preço, mas é de mais difícil negociação quando estão presentes usuários de vários tipos na bacia. O que deve ser evitado, sempre, é a cobrança por porcentagem de redução de carga. Um pequeno lançamento que causa pouco impacto, se tiver a mesma redução porcentual que um grande lançamento, será prejudicado e o meio ambiente também, porque não ficará livre do impacto maior". 
Neste trabalho serão abordadas, de forma mais detalhada, três metodologias: a metodologia proposta pelo Estado de São Paulo através do Conselho Estadual de Recursos Hídricos - CRH, para o processo de cobrança (CRH, 1997), a metodologia apresentada por KELMAN (1997) que aborda a outorga e a cobrança pelo uso da água e a metodologia de cobrança pelo uso da água na bacia do rio Paraíba do Sul (Deliberação CEIVAP no 08, de 06/12/2001).

A metodologia proposta pelo Conselho Estadual de Recursos Hídricos (CRH, 1997) é aqui apresentada como um exemplo que trabalha com custos unitários de captação e lançamento definidos, tanto para o valor mínimo como para o valor máximo, cujos preços de lançamento e captação são ponderados pelo uso de coeficientes. A metodologia proposta por KELMAN (1997) é aqui apresentada por esta estar apoiada em considerações das características físicas do corpo hídrico, o que vai ao encontro da proposta deste trabalho. É abordada também a cobrança pelo uso da água na bacia do rio Paraíba do Sul, iniciada em janeiro de 2003, por estar servindo atualmente como modelo de cobrança no cenário nacional para águas de domínio da União.

\section{Cobrança pelo uso da água no Estado de São Paulo}

A Lei 7.663, sancionada em 30 de dezembro de 1991, instituiu a Política Estadual de Recursos Hídricos e o Sistema Integrado de Gerenciamento de Recursos Hídricos, no Estado de São Paulo.

Um dos instrumentos da Lei 7.663, definido nos artigos 9 e 10, é a Outorga de Direito de Uso dos Recursos Hídricos, regulamentada pelo Decreto Estadual 41.258 de 01/11/96, e normatizada pela Portaria DAEE 717 de 12/12/96.

Na Portaria 717, art. 5, inciso II, fica estabelecido:

Art. 5 - "Dependerão de outorga do direito de uso, passada pelo DAEE:

II - os lançamentos de efluentes nos corpos d'água, obedecidas a legislação federal e a estadual pertinentes à espécie."

Neste caso fica entendido que a Lei 7.663, no que diz respeito ao lançamento de efluentes no corpo receptor, obedecerá a legislação da Resolução CONAMA n. ${ }^{\circ} 20$ e do 
Decreto Estadual 8.468 (Regulamenta a Lei Estadual n. ${ }^{\circ}$ 997, que dispõe sobre a Prevenção e o Controle da Poluição do Meio Ambiente).

A Lei 7.663, através do art. 14, inciso II, estabelece a cobrança pela diluição, transporte e assimilação de efluentes de sistemas de esgotos e de outros líquidos, de qualquer natureza, considerando: a classe de uso em que for enquadrado o corpo d'água receptor; o grau de regularização assegurado por obras hidráulicas; a carga lançada e seu regime de variação.

No Estado de São Paulo, na Assembléia Legislativa, está em processo de discussão a aprovação do Projeto de Lei 676/00, que transforma a água em bem econômico, instituindo a cobrança pelo seu uso.

O Projeto de Lei 676/00 estabelece que os recursos obtidos com a cobrança serão destinados à bacia em que foram arrecadados, e investidos em preservação, ficando a decisão da aplicação dos recursos obtidos em outras bacias sob responsabilidade do respectivo Comitê de Bacia.

No Projeto de Lei, a fixação dos valores fica a critério do Comitê de Bacias com representação de $40 \%$ dos votos da sociedade civil, 30\% do município e 30\% dos votos do Estado. O valor cobrado para captação passa a ser limitado a 0,001078 UFESP's $/ \mathrm{m}^{3}$, ou seja, R\$ 0,01// $\mathrm{m}^{3}(12 / 11 / 2004)$.

No Estado de São Paulo foi proposta uma metodologia pelo Conselho Estadual de Recursos Hídricos - CRH para o processo de cobrança (CRH, 1997).

Na metodologia, em todo o estado de São Paulo, é proposta a adoção de "Preços Unitários Básicos" e "Coeficientes Multiplicadores", para cobrança de uso de recursos hídricos. A Tabela 2.1 apresenta "Preços Unitários Básicos - PUB”.

A conta total a ser paga, a título de cobrança pelo uso dos recursos hídricos, seria calculada através da aplicação da seguinte expressão:

$$
\mathrm{C}_{2}=\mathrm{PUF}_{\mathrm{Cap}} \cdot \mathrm{Q}_{\mathrm{Cap}}+\mathrm{PUF}_{\mathrm{Cons}} \cdot \mathrm{Q}_{\mathrm{Cons}}+\mathrm{PUF}_{\mathrm{DBO}} \cdot \mathrm{Q}_{\mathrm{DBO}}+\mathrm{PUF}_{\mathrm{DQO}} \cdot \mathrm{Q}_{\mathrm{DQO}}+\mathrm{PUF}_{\mathrm{RS}} \cdot \mathrm{Q}_{\mathrm{RS}}+\ldots
$$


$\mathrm{PUF}_{\mathrm{CI}} \cdot \mathrm{Q}_{\mathrm{CI}}$

Sendo:

$\mathrm{C}_{2}$ a conta total;

$\mathrm{Q}_{\mathrm{Cap}}, \mathrm{Q}_{\mathrm{Cons}}, \mathrm{Q}_{\mathrm{DBO}}, \mathrm{Q}_{\mathrm{DQO}}, \mathrm{Q}_{\mathrm{RS}}, \mathrm{Q}_{\mathrm{CI}}$ as quantidades utilizadas ou lançadas, de cada parâmetro; $\mathrm{PUF}_{\mathrm{Cap}}, \mathrm{PUF}_{\mathrm{Cons}}, \mathrm{PUF}_{\mathrm{DBO}}, \mathrm{PUF}_{\mathrm{DQO}}, \mathrm{PUF}_{\mathrm{RS}}, \mathrm{PUF}_{\mathrm{CI}}$ os Preços Unitários Finais para cada parâmetro, obtidos de:

$$
\begin{aligned}
& \mathrm{PUF}_{\text {Cap }}=P U B_{C a p} \cdot \mathrm{x}_{1} \cdot \mathrm{x}_{2} \ldots . \mathrm{x}_{\mathrm{f}} \\
& \mathrm{PUF}_{\text {Cons }}=P U B_{\text {Cons }} \cdot \mathrm{x}_{1} \cdot \mathrm{x}_{2} \ldots . \mathrm{x}_{\mathrm{f}} \\
& \mathrm{PUF}_{\mathrm{DBO}}=P U B_{D B O} \cdot \mathrm{y}_{1} \cdot \mathrm{y}_{2} \ldots \mathrm{y}_{\mathrm{f}} \\
& \mathrm{PUF}_{\mathrm{DQO}}=P U B_{D Q O} \cdot \mathrm{y}_{1} \cdot \mathrm{y}_{2} \ldots . \mathrm{y}_{\mathrm{f}} \\
& \mathrm{PUF}_{\mathrm{RS}}=P U B_{R S} \cdot \mathrm{y}_{1} \cdot \mathrm{y}_{2} \ldots . \mathrm{y}_{\mathrm{f}} \\
& \operatorname{PUF}_{\mathrm{CI}}=P U B_{C I} \cdot \mathrm{y}_{1} \cdot \mathrm{y}_{2} \ldots . \mathrm{y}_{\mathrm{f}}
\end{aligned}
$$

e os coeficientes multiplicadores $\mathrm{x}_{1}, \mathrm{x}_{2}, \ldots . \mathrm{x} \quad \mathrm{f} ; \mathrm{y}_{1}, \mathrm{y}_{2}, \ldots . . \mathrm{y} \quad \mathrm{f}$, etc., são apresentados em tabela.

Tabela 2.1 - Tabela de "Preços Unitários Básicos"

\begin{tabular}{|l|c|c|c|}
\hline \multicolumn{1}{|c|}{ Item } & unidade & símbolo & PUB (Preço Unitário Básico) em R\$ \\
\hline 1. Captação & $\mathrm{m}^{3}$ & PUB $_{C a p}$ & 0,01 \\
\hline 2. Consumo & $\mathrm{m}^{3}$ & $\mathrm{PUB}_{\text {Cons }}$ & 0,02 \\
\hline 3. Lançamentos & & & 0,10 \\
- de DBO & $\mathrm{kg}$ DBO & $\mathrm{PUB}_{D B O}$ & 0,05 \\
- de DQO & $\mathrm{kg} \mathrm{DQO}$ & $\mathrm{PUB}_{D Q O}$ & 0,01 \\
- de RS & litro & $\mathrm{PUB}_{R S}$ & 1,00 \\
- de CI & $\mathrm{kg}$ & $\mathrm{PUB}_{C I}$ & \\
\hline
\end{tabular}

DBO - Demanda Bioquímica de Oxigênio; DQO - Demanda Química de Oxigênio; RS - Resíduo Sedimentável; CI - Carga Inorgânica 
A Tabela 2.2 apresenta os coeficientes multiplicadores para lançamentos (diluição, transporte e assimilação de efluentes).

Tabela 2.2 - Coeficientes multiplicadores para lançamentos

\begin{tabular}{|c|c|c|c|c|c|c|c|c|c|}
\hline \multirow[t]{2}{*}{ UGRHI } & \multicolumn{3}{|c|}{$\operatorname{Origem}\left(y_{1}\right)$} & \multicolumn{4}{|c|}{$\begin{array}{l}\text { Classe do Corpo } \\
\text { Receptor }\left(y_{2}\right)\end{array}$} & $\begin{array}{l}\text { Sazonalidade } \\
\left(y_{3}\right) \ldots \ldots . . . \text { etc. }\end{array}$ & $\ldots . .\left(y_{f}\right)$ \\
\hline & Urbana & Industr. & Irrigação & 1 & 2 & 3 & 4 & Abr/Out Nov/Mar & .....Outros \\
\hline Alto Tietê & 0,8 & 1,3 & 1,0 & -- & 1,5 & 1,0 & 0,9 & & \\
\hline Piracicaba & 0,8 & 1,3 & 1,0 & -- & 1,2 & 1,0 & 0,9 & & \\
\hline B.Santista & 0,8 & 1,3 & 1,0 & -- & 1,5 & 1,0 & 0,9 & & \\
\hline
\end{tabular}

COEFICIENTES MULTIPLICADORES INDICADOS APENAS PARA FINS ILUSTRATIVOS

Os Preços Unitários Finais calculados, conforme as expressões acima, deverão ser limitados superiormente, visando evitar que se alcancem cifras demasiadamente elevadas. Assim sendo, embora os Comitês tenham liberdade de estabelecer os coeficientes multiplicadores de acordo com os seus interesses regionais ou locais, os Preços Unitários Finais para cada parâmetro não deverão ser superiores aos da Tabela 2.3 .

Tabela 2.3 - Valores limites estimados para os Preços Unitários Finais

\begin{tabular}{|l|c|c|}
\hline \multicolumn{1}{|c|}{ Item } & unidade & PUM (Preço Unitário Máximo) em R \$ \\
\hline 1. Captação & $\mathrm{m}^{3}$ & 0,05 \\
\hline 2. Consumo & $\mathrm{m}^{3}$ & 0,10 \\
\hline 3. Lançamentos & $\mathrm{kg} \mathrm{DBO}$ & 1,00 \\
- de DBO & $\mathrm{kg} \mathrm{DQO}$ & 0,50 \\
- de DQO & litro & 0,10 \\
- de RS & $\mathrm{kg}$ & 10,00 \\
- de CI & & \\
\hline
\end{tabular}


BRANCO e CORDEIRO (2003) desenvolveram um trabalho que apresenta algumas reflexões sobre a operacionalização do Fundo Estadual de Recursos Hídricos do Estado de São Paulo - FEHIDRO, sob a ótica do princípio participativo. Segundo os autores, "Embora exista hoje uma estrutura legalmente implantada no Estado para a gestão dos recursos hídricos, com princípios, objetivos, órgãos e colegiados com funções claramente definidas, a atuação governamental no campo da gestão participativa ainda é pouco expressiva, quando não inibidora. Da mesma forma, a gestão financeira do Fundo apresenta concepção conservadora, sem contemplar a gestão com a sociedade civil como princípio elementar. Essa ainda é considerada uma concessão".

\section{Metodologia proposta por KELMAN (1997)}

A metodologia de KELMAN (1997) propõe a cobrança pelo direito de usar, que pressupõe que o pagamento pelo usuário da água cresça com a quantidade outorgada e que a quantidade utilizada coincida com a respectiva quantidade outorgada. A cobrança pelo uso da água estabelece que a conta a ser paga pelo usuário seria limitada à parcela referente à cobrança pelo direito de usar somada à cobrança pelo uso efetivo da água de cada usuário. E, por fim, o estabelecimento de preço diferenciado para cada usuário, que estabelece a cobrança em função da prioridade de atendimento, baseada na organização dos usuários em uma "fila" de prioridades para acesso à água caso haja racionamento em uma situação de escassez. O texto abaixo foi extraído da metodologia de KELMAN (1997).

a) Cobrança pelo direito de usar

Partindo-se da compreensão que a contribuição $\alpha$ serve para custear o sistema de outorga, ainda que parcialmente, seria razoável cobrar o mesmo valor $\alpha$ para todos os usuários, já que todos saem beneficiados. Por outro lado, se cada usuário conseguir a outorga da quantidade que bem entenda, a tendência será de que ele venha a solicitar mais do que necessita.

Para um melhor uso racional da água é conveniente adotar um incentivo econômico para que cada usuário solicite a outorga apenas da quantidade que efetivamente 
necessite. Por exemplo, considerando um pagamento pelo usuário $i^{*}$ que cresça com a quantidade outorgada, $\beta *\left(i^{*}\right)$.

A quantidade outorgada deve estar relacionada ao impedimento de utilização de água por parte dos outros usuários, para cada trecho $k^{*}$, ao longo do intervalo $\Delta \mathrm{t}$, definido como $\mathrm{r}_{\mathrm{p}, \mathrm{k}^{*}}\left(\mathrm{i}^{*}, \mathrm{t}\right)$. Portanto, tem-se que:

$$
\beta_{*}\left(i^{*}\right)=\sum_{\mathrm{t}=1}^{\mathrm{T}_{*}} \sum_{\left.\mathrm{k}^{*} \in J \mathrm{i}^{*}\right)} \sum_{\mathrm{p} \geq 0} \mathrm{~d}_{\mathrm{p}, \mathrm{k}}\left(\mathrm{i}^{*}, \mathrm{t}\right), \text { onde }
$$

$\mathrm{d}_{\mathrm{p}, \mathrm{k}^{*}}(\mathrm{t})$ é o preço unitário do direito de uso da água, no trecho $\mathrm{k}^{*}$, no intervalo $\Delta \mathrm{t}$, (em $\$ / \mathrm{m}^{3}$ ou $\$ / \mathrm{m}^{3} / \mathrm{s}$ ) para diluir o poluente $\mathrm{p}>0$. No caso $\mathrm{p}=0, \mathrm{~d}_{0, \mathrm{k}^{*}}(\mathrm{t})$ é o preço unitário do direito de uso consuntivo. $\mathrm{T} *$ é o número de intervalos $\Delta \mathrm{t}$ em que o ano pode ser dividido (12, no caso em que $\Delta \mathrm{t}$ seja o mês). $\mathrm{J}\left(i^{*}\right)$ é o conjunto de trechos situados a jusante do usuário $i^{*}$.

Neste procedimento, o usuário $i *$ pagará a anuidade:

$$
\text { anuidade }\left(\mathrm{i}^{*}\right)=\max \left[\alpha, \beta *\left(\mathrm{i}^{*}\right)\right]
$$

Este equacionamento pressupõe que a quantidade utilizada coincida com a respectiva quantidade outorgada.

\section{b) Cobrança pelo uso da água}

Num intervalo $\Delta \mathrm{t}$ pode ocorrer que o usuário $i^{*}$ não tenha serventia para toda a água garantida por sua outorga. Caso a cobrança pelo uso da água pudesse ser baseada no efetivo consumo haveria um estímulo para a re-alocação. A sobra de água poderá ser aproveitada por algum outro usuário que circunstancialmente necessite mais água do que a garantida por sua outorga.

Neste sistema a conta a ser paga pelo usuário seria limitada a duas parcelas, $\max \left[\alpha, \beta *\left(i^{*}\right)\right]+\gamma\left(i^{*}\right)$, onde $\gamma\left(i^{*}\right)$ corresponderia a cobrança pelo uso efetivo da água. 
Para implementar um sistema desse tipo, seria necessário medir, ou pelo menos estimar, o efetivo consumo de cada usuário, a cada $\Delta t$, independente se esteja ou não ocorrendo uma situação de "stress" hídrico.

\section{c) Preço diferenciado para cada usuário}

Proposta baseada na cobrança diferenciada pela prioridade de atendimento, que admite $\gamma\left(i^{*}\right)=0$, sendo associada em situação de "stress" hídrico e baseada em regras simples, que podem ser controladas pelos próprios usuários.

A idéia de se processar ao racionamento numa certa ordem previamente estabelecida não precisa estar atrelada ao conceito cronológico. Quando se organiza os usuários numa "fila" de prioridades para acesso à água todos sabem exatamente como deve ocorrer o racionamento numa situação de escassez. A prioridade de uso da água será estabelecida através da ordem crescente do preço unitário declarado por cada usuário.

Com esta regra, a tendência do usuário $i^{*}$ será não apenas de solicitar a outorga mínima possível, como também a de adequar, a cada ano, os valores de $\mathrm{d}_{\mathrm{p}, \mathrm{k}^{*}}\left(\mathrm{i}^{*}, \mathrm{t}\right)$ à expectativa que tenha de real utilização da água. Se esta expectativa for baixa, o usuário $i *$ decidirá por baixos valores. E vice-versa. Alcança-se desta maneira a meta de conseguir uma alocação racional da água, através da cobrança.

\section{Cobrança no rio Paraíba do Sul}

O primeiro rio brasileiro a ter a cobrança pelo uso da água instituída é o Paraíba do Sul, cuja cobrança foi iniciada em janeiro de 2003. Este rio banha os estados de São Paulo, Rio de Janeiro e Minas Gerais. Atualmente está servindo como modelo de cobrança no cenário nacional para águas de domínio da União. O comitê responsável pela gestão desta bacia é o CEIVAP - Comitê para Integração da Bacia do Rio Paraíba do Sul (http://www.ana.gov.br). 
A Deliberação CEIVAP $n^{\circ}$ 03/2001 aprova a Implantação da Cobrança pelo Uso de Recursos Hídricos de Domínio da União na Bacia do Rio Paraíba do Sul a partir de 2002.

No Art. $2^{\circ}$, da Deliberação CEIVAP n ${ }^{\circ}$ 03/2001, fica aprovado o valor de R 0,02 (dois centavos de reais) o Preço Público Unitário, por metro cúbico, para cálculo do valor da cobrança pelo uso de recursos hídricos de domínio da União na Bacia do Rio Paraíba do Sul referente à captação de água, consumo e lançamento de efluentes, pelos usuários sujeitos à outorga.

A formulação de cobrança instituída pelo CEIVAP, através da Deliberação CEIVAP ${ }^{\circ}$ 08, de 06/12/2001, adota a seguinte expressão:

\footnotetext{
Valor Mensal $=\operatorname{Qcap}_{m} \cdot K_{10 \cdot} \cdot P P U+\mathbf{Q c a p}_{m} \cdot K_{11} \cdot \mathbf{P P U}+\operatorname{Qcap}_{m} \cdot\left(1-K_{11}\right) \cdot\left(1-K_{12} \cdot\right.$ $\left.K_{13}\right) . P P U$

A $1^{\text {a }}$. parcela da fórmula representa a cobrança pelo volume de água captada no manancial, a $2^{\text {a }}$. parcela representa a cobrança pelo consumo (volume captado que não retorna ao corpo hídrico), já a terceira parcela da equação representa a cobrança pelo despejo do efluente no corpo hídrico.

Onde:

Qcap $_{\mathrm{m}}=$ volume da água captada durante um mês, $\left(\mathrm{m}^{3} / \mathrm{mês}\right)$;

$\mathrm{K}_{10}=$ multiplicador de preço unitário para captação (inferior a 1 e definido pelo Comitê). O artigo 2 estabelece o valor de 0,4 (quatro décimos) para " $\mathrm{K}_{10}$ ", (adimensional);

$\mathrm{K}_{11}=$ coeficiente de consumo (uso consultivo) para a atividade em questão, ou seja, a relação entre o volume consumido e o volume captado pelo usuário, (adimensional);

$\mathrm{K}_{12}=$ percentual do volume de efluentes tratados em relação ao volume total de efluentes produzidos, ou a razão efluente tratada e a vazão efluente bruta, (adimensional);

$\mathrm{K}_{13}=$ eficiência de redução da carga orgânica (medida em Demanda Bioquímica de Oxigênio - DBO) do tratamento de efluentes do usuário, (adimensional); 
PPU = Preço Público Unitário pelo uso da água, seja para captação, consumo e ou diluição de efluentes, $\left(\mathrm{R} \$ / \mathrm{m}^{3}\right)$. O valor estabelecido na Deliberação CEIVAP 08/2001 é de R $\$ 0,02 / \mathrm{m}^{3}$.

SOUSA (2003) desenvolveu um trabalho que analisa a formulação de cobrança utilizada pelo CEIVAP, assim como aponta os problemas de representação e legitimidade para respaldar a aplicação do instrumento econômico. Segundo SOUSA (2003), as considerações a partir desta análise mostram uma necessidade de ampliação dos espaços de participação social bem como do aperfeiçoamento do instrumento de cobrança, o qual, na atual concepção, não incorpora as premissas preconizadas na legislação federal sobre o tema.

THOMAS, MAGALHÃES e AZEVEDO (2003) apresentaram uma metodologia de cobrança que considera o impacto de um determinado usuário sobre os demais usuários da bacia hidrográfica, este impacto foi denominado pelos autores de "escassez de outorga". Os cálculos foram realizados com o auxílio de um modelo de outorgas, que determina a vazão outorgável. A metodologia foi aplicada à bacia do rio Paraíba do Sul, que segundo os autores: "Devido todas as simplificações adotadas no cálculo, não se pode considerar os valores encontrados de escassez, e conseqüentemente de cobrança, como realidade da bacia. Ressalte-se, entretanto, que o objetivo de demonstrar a aplicabilidade da metodologia proposta foi plenamente alcançado. À medida que se conhecer melhor a disponibilidade e demandas hídricas da bacia e o modelo de análise de outorga for consolidado, os valores de escassez calculados serão cada vez mais precisos".

\subsubsection{Sistema de Informações sobre Recursos Hídricos}

O artigo 25, da Lei 9.433, estabelece: "O Sistema de Informações sobre Recursos Hídricos é um sistema de coleta, tratamento, armazenamento e recuperação de informações sobre recursos hídricos e fatores intervenientes em sua gestão". 
Art. 26, da Lei 9.433. São princípios básicos para o funcionamento do Sistema de Informações de Recursos Hídricos:

I - descentralização da obtenção e produção de dados e informações;

II - coordenação unificada do sistema;

III - acesso aos dados e informações garantido à toda a sociedade.

Para a efetiva aplicação da Política Nacional de Recursos Hídricos existe a necessidade de um Sistema de Informações sobre Recursos Hídricos que contenha informações quantitativas e qualitativas da bacia hidrográfica e da região em estudo. Estas informações irão servir de base para a alimentação de modelos matemáticos e sistemas de suporte a decisão, viabilizando tomada de decisões de forma mais racional.

Dados de monitoramento, sobretudo, de qualidade da água, devido à pouca quantidade de dados desta natureza disponíveis no país, precisam ser divulgados e disponibilizados, de forma a colaborarem e/ou complementarem o Sistema de Informações sobre Recursos Hídricos.

O Projeto Brasil das Águas (GÉRARD E MAGI MOSS) é um exemplo, baseado nos resultados obtidos pelas análises e substanciado por fotografias aéreas de cada local de amostragem, será desenhado um mapa da saúde das nossas águas doces e serão identificados ambientes não contaminados para que possam ser conservados. Utilizando pela primeira vez a mesma metodologia em todo o país, no final do ano 2004, o Projeto Brasil das Águas terá criado uma linha de base referencial de um dos maiores bens do nosso povo: a água (http://www.brasildasaguas.com.br).

CASTELLO et al. (2003) apresentaram o plano de monitoramento quali-quantitativo da região do Alto Tietê (SP), que está sendo desenvolvido. O plano foi criado com o objetivo de medir os impactos na qualidade das águas advindos da melhoria da infraestrutura sanitária previstas na segunda etapa do Projeto Tietê. O Projeto Tietê foi criado pelo Governo do Estado de São Paulo com o apoio do Banco Interamericano de Desenvolvimento (BID). A rede de monitoramento é constituída de mais de 30 pontos e 
foi elaborada com a peculiaridade dos dados de vazão serem obtidos concomitantemente ao processo de coleta de amostras de qualidade das águas, fornecendo subsídios para o cálculo das cargas poluentes veiculadas no rio Tietê, para a obtenção de dados mais consistentes e para a elaboração de prognósticos mais precisos através do uso do modelo matemático de qualidade das águas QUAL2E. Os dados do monitoramento podem ser obtidos através do site http://www.sabesp.com.br.

\subsection{Sistemas de suporte a decisão}

Sistemas de Suporte a Decisão são sistemas constituídos por bases de dados e modelos matemáticos que interagindo entre si, propiciam, através de uma interface gráfica, o diálogo entre o tomador de decisões e o computador. O planejamento e gerenciamento de recursos hídricos, devido às diversas variáveis envolvidas, são problemas complexos que podem ser melhores estruturados através do uso dessas ferramentas, propiciando tomadas de decisões mais rápidas e precisas. PORTO e AZEVEDO (1997).

A Figura 2.1 apresenta a estrutura típica de um sistema de suporte a decisão.

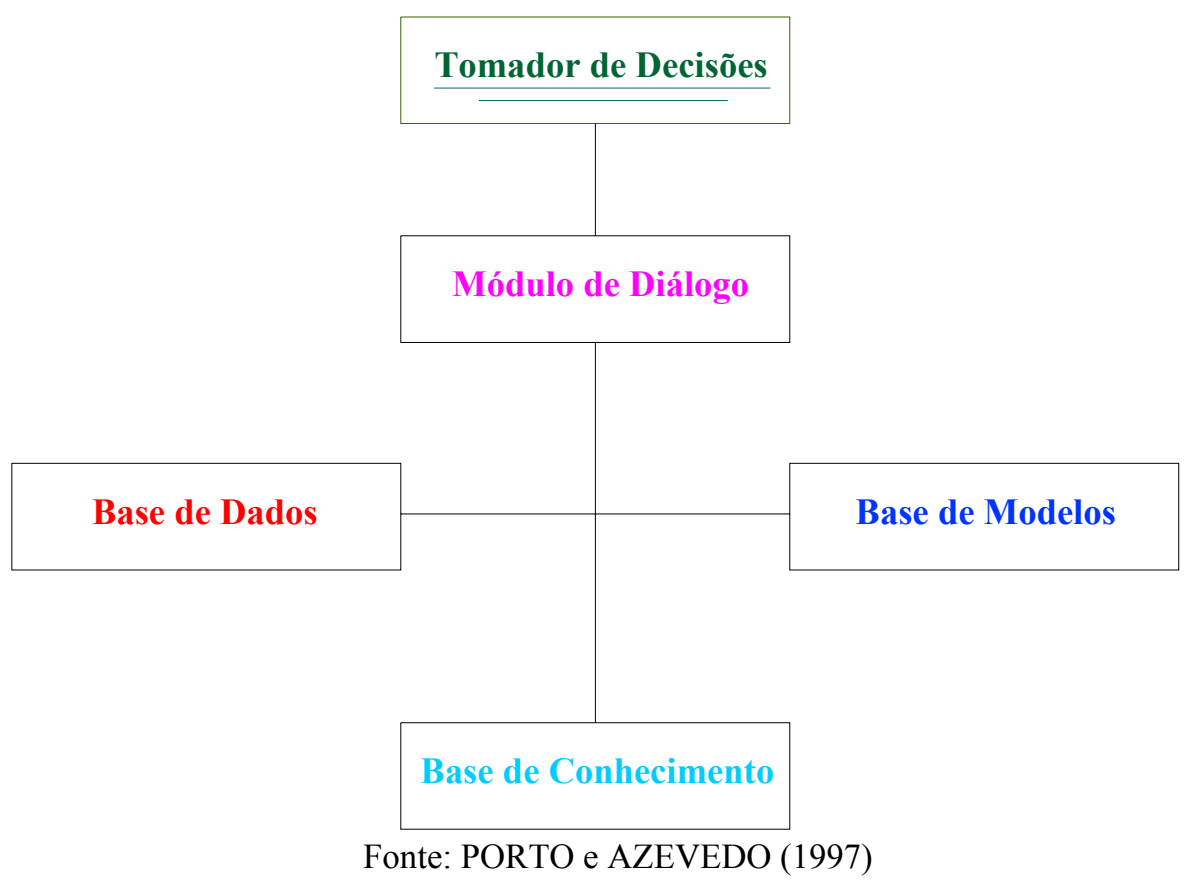

Figura 2.1 - Estrutura típica de um sistema de suporte a decisão 
A figura acima apresenta os seguintes componentes (PORTO e AZEVEDO, 1997):

- $\quad$ Base de Dados: reúne e gerencia as informações do sistema;

- $\quad$ Base de Modelos: contém os modelos utilizados no sistema para atendimento a solução do problema;

- Base de Conhecimentos: conhecimentos que implicam na experiência de especialistas, permitindo geralmente a incorporação de informações que não são passíveis de tratamento pelos módulos anteriores;

- Módulo de Diálogo: responsável pela comunicação do usuário com o computador.

CRUZ et al. (2003) desenvolveram um sistema, denominado SISMODH (Sistema Modular de Avaliação da Disponibilidade Hídrica), como uma alternativa de equacionamento para a avaliação da disponibilidade hídrica para outorga, visando o balanço hídrico otimizado na bacia. O sistema foi aplicado à bacia do rio Jucuí (RS). Segundo os autores: "A vantagem do modelo é o aspecto agregador de informações: se mais dados ou mais recursos para estudos houver, melhores avaliações serão produzidas até as seções hidrológicas de referências, adequando e evoluindo o conhecimento do estado dos mananciais hídricos e diminuindo incertezas das estimativas para outorga".

ALMEIDA, BRAGA e ROSA (2003) abordaram o desenvolvimento do Sistema de Gestão de Outorga do Estado da Paraíba (AAGISA). O sistema apresenta três componentes: banco de dados, aplicativo e o sistema de informações geográficas, que segundo os autores, possibilita a espacialização das informações sobre outorgas e uso dos recursos hídricos existentes no Estado da Paraíba.

MEDEIROS et al. (2001) apresentaram o Sistema de Apoio a Decisão para Pleito de Outorga e Cobrança (SAD), de acordo com os requerimentos estabelecidos pela Superintendência de Recursos Hídricos do Estado da Bahia. Este sistema está dividido em quadro módulos: Sistemas de Informações Geográficas - SIG; cálculo de demanda 
de irrigação; modelação hidrológica e apresentação de resultados. LORDÊLLO et al. (2003) apresentaram a situação atual das outorgas no Estado da Bahia, considerando todos os aspectos que difundiu o estado como sendo um dos primeiros na gestão de recursos hídricos no país.

FIGUEIREDO e RUBERT (2001) apresentaram a proposta de um processo de análise das informações sobre recursos hídricos, espacializadas em um Sistema de Informações Geográficas, como o objetivo de dar suporte à tomada de decisão, no âmbito de concessão de outorga do direito de uso de águas superficiais. O estudo de caso foi realizado na bacia do rio Jequitinhonha (MG) para verificar a disponibilidade hídrica no ponto de solicitação de concessão de outorga. Segundo os autores: "Ressalve-se ainda que, apesar deste trabalho ter abordado apenas os aspectos quantitativos dos recursos hídricos, não se pode desprezar o ambiente aquático como um todo, seus usos múltiplos e principalmente os padrões de qualidade, ou seja, o monitoramento da ação antropogênica do meio".

CARVALHO et al. (2003) apresentaram um Sistema de Suporte a Decisão, a partir da adaptação do modelo ModSimLS, denominado ModSimLSA. Com a adaptação o modelo considera a produção agrícola como resultado da interação dos fatores água, clima, planta e solo. O sistema foi aplicado à bacia do rio Itapicuru (BA). Foi realizada um análise comparativa entre a aplicação dos modelos ModSimLS e ModSimLSA. Segundo os autores, verificou-se que o modelo ModSimLSA apresenta algumas vantagens sobre o ModSimLS para trabalhar com reservatório do solo.

TEXEIRA, SCHARDONG e PORTO (2003) integraram em um modelo de rede de fluxo (ACQUANET) um modelo de qualidade da água por eles desenvolvido (QualidadeCLS). Com o objetivo de determinar concentrações de variáveis de qualidade da água em rios. Foi apresentado um exemplo demonstrativo de aplicação do modelo QualidadeCLS, para as variáveis DBO e OD. Segundo os autores, os resultados foram satisfatórios quando comparados com o modelo de qualidade das águas QUAL2E.

ROBERTO (2002) desenvolveu um trabalho sobre modelos de rede de fluxo para alocação da água entre múltiplos usos em uma bacia hidrográfica. Este trabalho aborda conceitos sobre modelos de rede de fluxo e suas aplicações. 
CASTRO e PORTO (2003) utilizaram um Sistema de Suporte a Decisão, denominado ACQUANET, para avaliar a disponibilidade hídrica na Região Metropolitana de São Paulo, assim como a integração entre os sistemas produtores existentes, visando a minimização de conflitos.

BALTAR e CORDEIRO (2001) apresentaram um sistema de apoio a decisões (ModSimP32-E) para análise integrada da alocação de recursos hídricos entre vários usos quantitativos de uma bacia hidrográfica. Este sistema é uma ferramenta de planejamento que permite estudar o impacto econômico de longo prazo das mais diversas decisões. O sistema foi aplicado à bacia da barragem do rio Descoberto, no Distrito Federal.

BARROS et al. (2003), através da Escola Politécnica da USP, vêm desenvolvendo um projeto de pesquisa sobre gerenciamento de recursos hídricos em bacias urbanas. Para estudo de caso, foi selecionada a bacia do rio Cabuçu de Baixo (SP). O projeto considera vários aspectos, tais como hidrologia urbana, sistemas de macrodrenagem, poluição por fontes difusas, erosão e sedimentos, urbanização, etc. As informações e os modelos resultantes do estudo estão reunidos num Sistema de Suporte a Decisão para gerenciamento de bacias urbanas.

RODRIGUES e PORTO (2003) apresentaram uma interface gráfica para o modelo de qualidade das águas QUAL2E, denominada QUAL2R. A interface permite uma análise da qualidade das águas para diversos valores de vazão, dentro de um mesmo cenário de lançamentos e captações da bacia hidrográfica. A interface QUAL2R serviu de apoio para o desenvolvimento do sistema de suporte a decisão aqui proposto (SSD RB). 


\section{Capítulo 3}

\section{METODOLOGIA}

Neste capítulo, aborda-se o processo de autodepuração de um corpo hídrico e os principais processos envolvidos no mesmo, assim como conceitos de modelagem da qualidade da água. Descreve-se de uma forma mais detalhada os modelos utilizados no desenvolvimento do SSD RB, ou seja: o modelo de outorga e cobrança pelo uso da água RM1 e o modelo de qualidade das águas QUAL2E. É realizada também uma descrição do processo de modelagem da integração dos modelos RM1 e QUAL2E para desenvolvimento do SSD RB, assim como a articulação do SSD RB com os instrumentos de gestão da Política Nacional de Recursos Hídricos.

\subsection{Processo de autodepuração em rios}

Em países cujas redes e estações de tratamento de esgoto ainda não estão totalmente consolidadas, como é o caso atualmente do Brasil, os compostos orgânicos presentes em rios e córregos podem ter origem industrial, quando dessa atividade resulta o descarte de efluentes líquidos contendo substâncias orgânicas, mas sabe-se que a grande contribuição se dá pelo lançamento de esgoto sanitário como, por exemplo, ocorre na Região Metropolitana de São Paulo (RODRIGUES, 2003).

Quando um composto orgânico é lançado num rio sofre o processo natural de autodepuração. O processo de autodepuração é compreendido pela degradação, sedimentação, dispersão, diluição, reaeração, fotossíntese, dentre outros. Este processo leva ao restabelecimento das águas do rio às suas condições iniciais para as 
concentrações de matéria orgânica (representada pela DBO) e oxigênio dissolvido (OD). (Ver Figura 3.1)

Define-se demanda bioquímica de oxigênio (DBO) como sendo a quantidade necessária de oxigênio para a metabolização da matéria orgânica biodegradável existente no meio aquático. CHAPRA (1997)

Embora o conceito de DBO não sirva como única medida para avaliar o impacto em um rio através do despejo de poluentes, possibilita uma avaliação bastante importante do estado da qualidade da água de um determinado meio por ser uma medida direta do potencial consumo de oxigênio dissolvido no meio líquido.

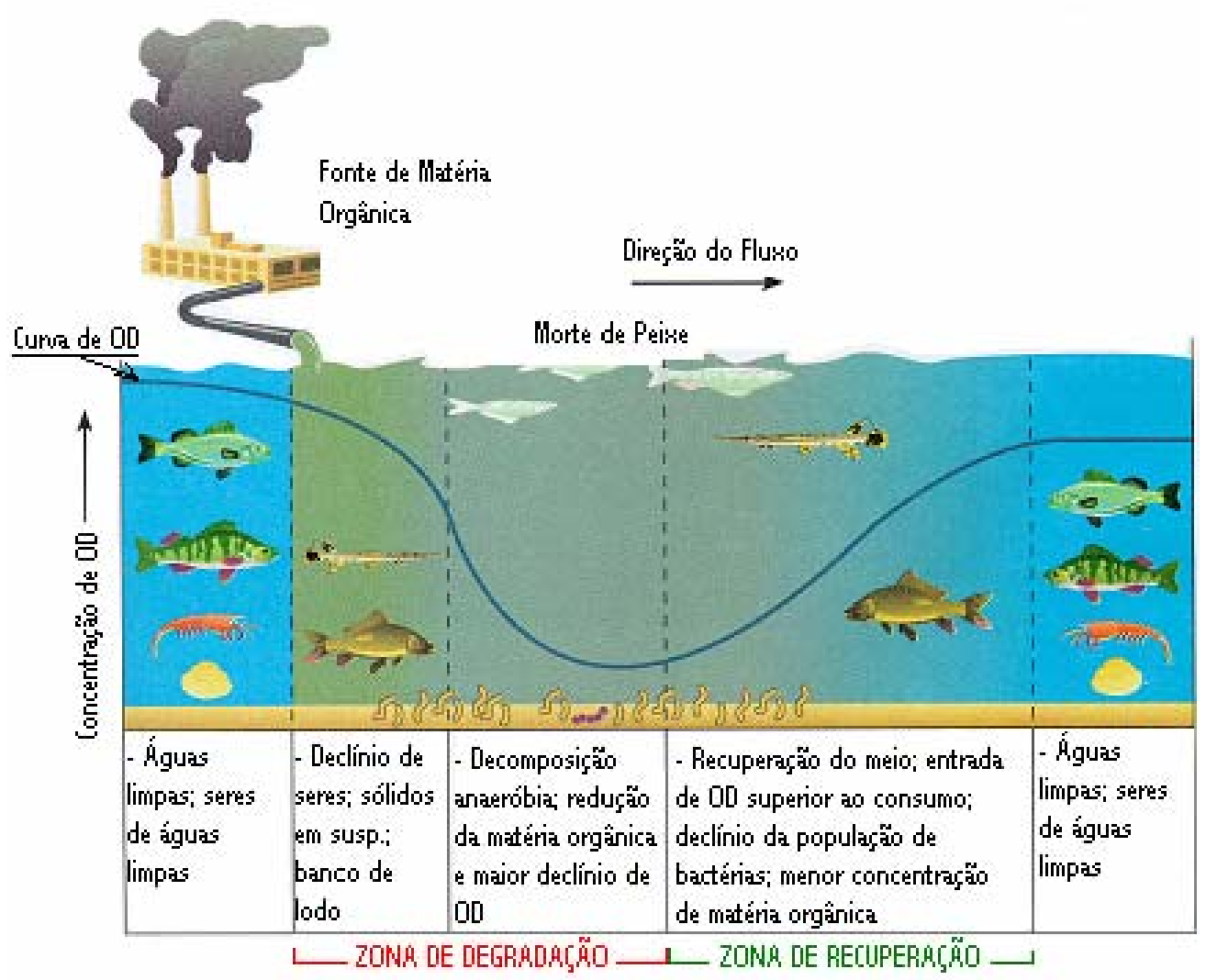

Fonte: Adaptado de PORTO (1997)

Figura 3.1 - Perfil esquemático dos processos de degradação e recuperação de um rio 
A capacidade de autodepuração de um corpo hídrico pode se expressar de uma forma mais simplificada através dos parâmetros de degradação $\left(K_{1}\right)$, reaeração $\left(K_{2}\right)$ e sedimentação $\left(\mathrm{K}_{3}\right)$, e demanda bentônica de oxigênio $\left(\mathrm{K}_{4}\right)$.

\subsubsection{Parâmetros de degradação, reaeração e sedimentação, e demanda bentônica de oxigênio}

\section{- Parâmetro de degradação $\left(K_{1}\right)$}

A taxa de degradação da matéria orgânica no meio líquido é representada pelo parâmetro de degradação $\mathrm{K}_{1}$. A Tabela 3.1 apresenta a ordem de grandeza da constante de decomposição $\left(\mathrm{K}_{1}\right)$ usualmente assumida em laboratório.

Tabela 3.1 - Ordem de grandeza da taxa de degradação $\left(\mathrm{K}_{1}\right)$ a $20{ }^{\circ} \mathrm{C}$, assumida em laboratório.

\begin{tabular}{|l|c|}
\hline \multicolumn{1}{|c|}{ Tratamento } & $\mathbf{K}_{\mathbf{1}}\left(\mathbf{2 0}{ }^{\circ} \mathbf{C}\right)$ \\
\hline Esgoto bruto & $0,35(0,20-0,50)$ \\
\hline Tratamento primário & $0,20(0,10-0,30)$ \\
\hline Tratamento secundário & $0,075(0,05-0,10)$ \\
\hline
\end{tabular}

Fonte: CHAPRA (1997)

\section{- Parâmetro de reaeração atmosférica $\left(K_{2}\right)$}

$\mathrm{O}$ parâmetro $\mathrm{K}_{2}$ representa a taxa de reaeração atmosférica, ou seja, a difusão oxigênio atmosférico do ar para o corpo receptor. $\mathrm{O}$ valor de $\mathrm{K}_{2}$ pode ser obtido através de fórmulas empíricas e semi-empíricas vinculadas a dados hidráulicos do sistema, ou por técnicas de medição. A medição do coeficiente de reaeração requer exaustivos trabalhos de campo e de laboratório, equipamentos e corpo técnico especializado.

A Tabela 3.2 apresenta algumas fórmulas empíricas para a previsão do coeficiente de reaeração $\mathrm{K}_{2}\left(\mathrm{dia}^{-1}\right)$, a $20^{\circ} \mathrm{C}$. A Tabela 3.3 mostra valores típicos de $\mathrm{K}_{2}$. 
Tabela 3.2 - Equações para o parâmetro de reaeração $\mathrm{K}_{2}\left(\operatorname{dia}^{-1}\right)$, a $20^{\circ} \mathrm{C}$.

\begin{tabular}{|c|c|c|c|c|c|}
\hline \multicolumn{6}{|c|}{ Fórmulas } \\
\hline \multicolumn{2}{|c|}{$\begin{array}{l}\text { O'Connor- Dobbins } \\
\qquad \mathrm{K}_{2}=3,93 \frac{\mathrm{U}^{0,5}}{\mathrm{H}^{1,5}} \\
\text { Válida para as faixas: }\end{array}$} & \multicolumn{2}{|c|}{$\begin{array}{c}\text { Churchill } \\
\mathrm{K}_{2}=5,026 \frac{\mathrm{U}^{0,969}}{\mathrm{H}^{1,67}} \\
\text { Válida para as faixas: }\end{array}$} & \multicolumn{2}{|c|}{$\begin{array}{c}\text { Owens-Gibbs } \\
\mathrm{K}_{2}=5,32 \frac{\mathrm{U}^{0,67}}{\mathrm{H}^{1,85}} \\
\text { Válida para as faixas: }\end{array}$} \\
\hline Velocidades & $0,15-0,50$ & Velocidades & $0,55-1,52$ & Velocidades & $0,03-0,55$ \\
\hline Profundidades & $0,30-9,10$ & Profundidades & $0,60-3,35$ & Profundidades & $0,10-0,73$ \\
\hline \multicolumn{6}{|c|}{ Onde: $U=$ velocidade média no trecho, $(\mathrm{m} / \mathrm{s}) \quad$ e $H=$ profundidade média no trecho, $(\mathrm{m})$} \\
\hline
\end{tabular}

Fonte: CHAPRA (1997)

Tabela 3.3 - Valores típicos do parâmetro de reaeração $\mathrm{K}_{2}\left(\mathrm{~d}^{-1}\right)$, a $20{ }^{\circ} \mathrm{C}$

\begin{tabular}{|l|c|}
\hline \multicolumn{1}{|c|}{ Corpo d'água } & $\begin{array}{c}\text { Coeficiente de reaeração } \\
\left(\mathbf{d}^{\mathbf{1}} \mathbf{)}\right.\end{array}$ \\
\hline Pequeno lago e reservatório & $0,10-0,23$ \\
\hline Curso de água lento e lago de grande dimensão & $0,23-0,35$ \\
\hline Curso de água de grande dimensão com velocidade baixa & $0,35-0,46$ \\
\hline Curso de água de grande dimensão com velocidade normal & $0,46-0,69$ \\
\hline Curso de água com velocidade alta & $0,69-1,15$ \\
\hline Corredeira e cachoeira & $>1,15$ \\
\hline
\end{tabular}

Fonte: TCHOBANOGLOUS e SCHROEDER, 1985

\section{- Parâmetro de sedimentação $\left(K_{3}\right)$ e demanda bentônica de oxigênio $\left(K_{4}\right)$}

Os sedimentos que se acumulam no fundo dos corpos d'água formam os chamados bancos de lodo ou camada bentônica e são resultantes do processo de sedimentação dos sólidos em suspensão.

A constante sedimentação e a formação de novas camadas de poluentes no banco de lodo faz com que apenas a camada superior, em contato com o meio líquido, possa vir a ser oxidada, caso haja oxigênio na região mais profunda do rio. As camadas abaixo desta, devido à ausência de oxigênio, sofrem o processo de decomposição anaeróbia.

O coeficiente de sedimentação é dado por:

$$
K_{3}=\frac{V S}{H}
$$

Onde: 
$\mathrm{K}_{3}=$ parâmetro de sedimentação, (1/d);

$\mathrm{Vs}=$ velocidade de sedimentação do poluente, $(\mathrm{m} / \mathrm{d})$;

$\mathrm{H}=$ profundidade média do leito do rio, $(\mathrm{m})$.

A Tabela 3.4 apresenta a velocidade média de sedimentação de algumas partículas e colóides suspensos no meio líquido, em condições ideais de laboratório. Na prática, sabe-se que as partículas coloidais, sob certas condições, juntam-se em flocos e, neste caso, as velocidades de sedimentação são maiores do que as de partículas dispersas.

Tabela 3.4 - Sedimentabilidade das partículas suspensas e colóides suspensos

\begin{tabular}{|c|c|c|}
\hline $\begin{array}{c}\text { Tamanho da Partícula } \\
\qquad(\mathrm{em} \mu \mathrm{m})\end{array}$ & Tipo de Material & $\begin{array}{l}\text { Velocidade de Sedimentação } \\
\text { (em m/dia) }\end{array}$ \\
\hline 100 & Areia fina & 682,6 \\
\hline 10 & silte & 13,0 \\
\hline 1 & bactéria & 0,13 \\
\hline 0,1 & colóide & 0,0013 \\
\hline 0,01 & colóide & 0,00013 \\
\hline
\end{tabular}

Fonte: Adaptado de BENN e Mc AULIFFE (1981)

A demanda de oxigênio dos sedimentos é expressa em $\mathrm{g} \mathrm{O}_{2} / \mathrm{m}^{2}$.dia, sendo exercida pela área superficial do leito do rio. (Ver Tabela 3.5)

Tabela 3.5 - Valores associados à demanda de oxigênio da camada bentônica

\begin{tabular}{|l|c|c|}
\hline \multirow{2}{*}{ Tipo de leito e situação local } & \multicolumn{2}{c|}{$\begin{array}{c}\text { Demanda bentônica } \\
\left(\mathbf{g ~ O} \mathbf{O}_{\mathbf{2}} / \mathbf{m}^{2} \text {.dia }\right.\end{array}$} \\
\cline { 2 - 3 } & Variação & Média \\
\hline Lodo de esgoto - nas proximidades do ponto de lançamento & $2-10$ & 4 \\
\hline Lodo de esgoto - a jusante do ponto de lançamento & $1-2$ & 1,5 \\
\hline Leito estuarino & $1-2$ & 1,5 \\
\hline Leito arenoso & $0,2-1,0$ & 0,5 \\
\hline Leito de solo mineral & $0,05-0.1$ & 0,07 \\
\hline
\end{tabular}

Fonte: THOMANN e MUELLER, 1987

Os valores dos parâmetros $\mathrm{K}_{1}, \mathrm{~K}_{2}$ e $\mathrm{K}_{3}$, e a demanda bentônica de oxigênio $\left(\mathrm{K}_{4}\right)$, para temperaturas diferentes de $20^{\circ} \mathrm{C}$, podem ser corrigidos através da seguinte relação: 


$$
\mathbf{K}_{\mathbf{m}, \mathbf{T}}=\mathbf{K}_{\mathrm{m}, 20^{\circ} \mathrm{C}} \cdot \theta^{(\mathrm{T}-20)}
$$

Onde:

$\mathrm{K}_{\mathrm{m}, \mathrm{T}}=$ parâmetro "m" considerado para uma dada temperatura " $\mathrm{T}$ ";

$\mathrm{T}=$ temperatura, $\left({ }^{\circ} \mathrm{C}\right)$;

$\theta=$ coeficiente de temperatura, (adimensional).

Os coeficientes de temperatura $\theta$ podem ser influenciados por diversos fatores associados à natureza do respectivo parâmetro. Valores encontrados na literatura são apresentados como default na Tabela 5.2 da pág. 106.

\subsection{Modelagem da qualidade da água}

Modelagem consiste na representação simplificada da realidade através do estabelecimento de hipóteses sobre a estrutura ou sobre o comportamento de um sistema físico. Dentro deste contexto, os modelos podem ser tidos como uma representação simplificada da realidade, tornando instrumentos úteis para avaliar o nível de conhecimento do sistema, as relações causas e efeitos, e para a organização das informações disponíveis no sistema.

Assim, a modelagem matemática surge como uma ferramenta de extrema importância no processo de gestão de uma bacia, dado que esta pode prever o conhecimento de porque algumas alternativas de manejo são melhores do que outras, tendo em vista a resposta do modelo matemático a diferentes descargas de resíduos. Neste sentido, podese diagnosticar o grau de tratamento que deve ser dado aos despejos que ultrapassem a capacidade de autodepuração do corpo receptor, associada à classe de uso estabelecida para o mesmo.

O conhecimento da capacidade de autodepuração do corpo receptor, assim como o conhecimento da capacidade de sedimentação e da retirada de massa do poluente no sistema, é importante para se ter um maior embasamento técnico do comportamento do poluente no corpo receptor. 
Na prática, a representação da degradação da matéria orgânica em um rio foi dada pela primeira vez através de um modelo de reação, denominado modelo de Streeter e Phelps. (CHAPRA, 1997)

O modelo de Streeter e Phelps (STREETER e PHELPS, 1925) estabelece que a variação da DBO remanescente (DBOr) em um infinitésimo de tempo (dt) é igual a DBOr multiplicada por uma constante de degradação $\mathrm{K}_{1}\left(\mathrm{t}^{-1}\right)$. Sendo:

$$
\frac{d\left(D B O_{r}\right)}{d t}=-K_{1}\left(D B O_{r}\right)
$$

Através da integração da equação acima:

$$
D B O u=\frac{D B O e(t)}{\left(1-e^{-K_{1} \cdot t}\right)}
$$

Onde:

DBOu - Demanda Bioquímica de Oxigênio total;

DBOe - Demanda Bioquímica de Oxigênio exercida.

A DBO última (DBOu) é a DBO remanescente (DBOr) somada a DBO exercida (DBOe). Logo:

$$
\mathrm{DBOu}=\mathrm{DBOr}+\mathrm{DBOe}
$$

O modelo de Streeter e Phelps também prevê o déficit de oxigênio dissolvido resultante da descarga de matéria orgânica em rios. O equacionamento de STREETER E PHELPS (1925), para o cálculo da concentração de OD, combina os processos de reaeração e desoxigenação pelo decaimento da matéria orgânica, chegando-se à equação do déficit de oxigênio dissolvido:

$$
D_{t}=\frac{K_{1} \cdot L_{0}}{K_{2}-K_{1}} \cdot\left(e^{-K_{1} \cdot t}-e^{-K_{2} \cdot t}\right)+D_{0} \cdot e^{-K_{2} \cdot t}
$$

Onde:

$\mathrm{D}_{\mathrm{t}}=$ déficit de oxigênio no instante " $\boldsymbol{t}$ "considerado, $(\mathrm{mg} / \mathrm{L})$;

$\mathrm{K}_{1}=$ parâmetro de degradação, (1/d);

$\mathrm{K}_{2}=$ parâmetro de reaeração, (1/d); 
$\mathrm{t}=$ Tempo, $(\mathrm{d})$

$\mathrm{D}_{0}=$ déficit inicial de oxigênio dissolvido, no ponto de mistura do efluente com o corpo receptor, que é dado pela concentração de saturação menos a concentração de mistura, $(\mathrm{mg} / \mathrm{L})$;

$\mathrm{L}_{0}=$ concentração de DBO no ponto de mistura do efluente com o corpo receptor, $(\mathrm{mg} / \mathrm{L})$.

O equacionamento de Streeter-Phelps pressupõe mistura imediata, logo, a concentração de mistura da $\mathrm{DBO}\left(\mathrm{L}_{0}\right)$ e a concentração de mistura de oxigênio dissolvido são obtidas através de balanço de massa.

Os cálculos do tempo crítico e do déficit crítico são dados por:

- Tempo crítico $\left(\mathrm{t}_{\mathrm{c}}\right)$

$$
t_{c}=\frac{1}{K_{2}-K_{1}} \ln \left[\frac{K_{2}}{K_{1}}\left(1-\frac{D_{0}\left(K_{2}-K_{1}\right)}{L_{0} \cdot K_{1}}\right)\right]
$$

- Déficit crítico $\left(D_{c}\right)$

$$
D_{c}=\frac{K_{1}}{K_{2}} \cdot L_{0} \cdot e^{-K_{1} \cdot t_{c}}
$$

Os problemas com esse equacionamento são:

- Pressupõe mistura imediata;

- Não leva em conta a dispersão;

- Não leva em consideração as características hidráulicas do corpo hídrico;

- Só funciona em decomposição aeróbia;

- Não inclui reoxigenação pela fotossíntese;

- Não inclui a sedimentação de matéria orgânica;

- Não inclui demanda bentônica.

O modelo de Streeter e Phelps, num primeiro momento, pode ser uma ferramenta útil para se prever ou diagnosticar, dentro de certa precisão, os danos gerados pelo lançamento de um efluente em um rio. 


\subsection{Modelo de qualidade das águas QUAL2E}

\subsubsection{Motivos da escolha do modelo QUAL2E para o SSD RB}

A escolha do modelo QUAL2E, para integrar o SSD RB, se deu pelos seguintes motivos:

- por este ser um modelo unidimensional, o que requer uma quantidade de dados de entrada relativamente pequena;

- pelo modelo QUAL2E ser bastante utilizado em vários países, o que garante credibilidade ao modelo;

- por ele trabalhar em regime permanente, o que implica na não necessidade de representar variações nas variáveis de estado em curto espaço de tempo;

- pela simplificação da geometria do canal, o que facilita o processo de calibração;

- pelo fato do modelo QUAL2E trabalhar com a divisão do corpo hídrico em trechos, possibilitando a entrada de dados de poluição difusa, o que viabiliza o processo de calibração do modelo, dentro de valores aceitáveis, principalmente, em trechos constituídos por sub-bacias que apresentam um alto número de ligações de esgoto não consolidadas, promovendo o carriamento ao corpo hídrico dessas cargas de origem "difusa" (não associadas propriamente a eventos de chuva), como, por exemplo, trechos do rio Tietê, na Região Metropolitana de São Paulo, que apresentam cargas de origem "difusa” de grande expressão;

- pelo fato do modelo QUAL2E considerar a demanda bentônica, o que viabiliza a calibração do modelo para a variável oxigênio dissolvido, dentro de valores aceitáveis, também para rios e córregos altamente poluídos e que apresentam uma alta capacidade de reaeração, como, por exemplo, o rio Tamanduateí, afluente do rio Tietê.

O texto apresentado neste item foi extraído do manual do modelo QUAL2E The Enhanced Stream Water Quality Models QUAL2E and QUAL2E-UNCAS, desenvolvido por BROWN e BARNWELL (EPA/600/3-87/007), que discute a teoria do modelo e fornece maior orientação sobre aplicações. Logo, para o uso do SSD RB, recomenda-se também a consulta do manual do modelo QUAL2E. 


\subsubsection{Características do modelo}

O modelo de simulação de qualidade da água Stream Water Quality Model - QUAL2E, 1987, distribuído pela US Environmental Protection Agency - USEPA, é um modelo de qualidade das águas superficiais que permite simular 15 variáveis indicativas de qualidade das águas em cursos de água ramificados e bem misturados, usando o método das diferenças finitas para a solução da equação unidimensional do transporte (advecção e dispersão) e de reação dos constituintes.

O modelo QUAL2E simula, de forma espacial, às seguintes variáveis indicativas da qualidade da água: DBO, OD, temperatura, alga (clorofila a), nitrogênio orgânico, amônia, nitrito, nitrato, fósforo orgânico, fósforo inorgânico dissolvido, coliformes, variável não-conservativa arbitrária, três variáveis conservativas arbitrárias.

Permite também a incorporação de descargas pontuais, tributários, captações e de incrementos de vazão e poluentes relacionados às fontes difusas. Hidraulicamente, limita-se à simulação de períodos de tempo em que tanto a vazão ao logo do curso principal, quanto às entradas e retiradas sejam essencialmente constantes.

\subsubsection{Equações do modelo QUAL2E}

\section{- Remoção de matéria orgânica}

No modelo QUAL2E, ocorre a remoção de matéria orgânica pelos processos de degradação e sedimentação do poluente no corpo hídrico. A equação utilizada pelo modelo é:

$$
\frac{d(D B O u-D B O e(t))}{d t}=-K_{1}(D B O u-D B O e(t))-K_{3}(D B O u-D B O e(t))
$$

Onde:

$\mathrm{DBOu}=$ Demanda Bioquímica de Oxigênio total, $(\mathrm{mg} / \mathrm{L})$;

DBOe = Demanda Bioquímica de Oxigênio exercida, $(\mathrm{mg} / \mathrm{L})$;

$\mathrm{K}_{1}=$ parâmetro de degradação, $\left(\mathrm{em} \mathrm{d}^{-1}\right)$;

$\mathrm{K}_{3}=$ parâmetro de sedimentação do poluente no sistema, (1/dia). 
O modelo de qualidade das águas QUAL2E caracteriza a reação das variáveis por ele simuladas como de primeira ordem, ou seja, a integração da concentração em função do tempo ocorre uma única vez. No modelo QUAL2E, o tempo representa o espaço percorrido e a velocidade do fluxo no corpo hídrico, considerando que a velocidade do poluente no eixo longitudinal é a mesma que a velocidade do fluxo e desconsiderando a velocidade do poluente no eixo vertical.

\section{- Modelação de oxigênio dissolvido}

A concentração de oxigênio dissolvido na água resulta de um balanço entre a quantidade consumida, a quantidade produzida e a quantidade injetada (tributários) no meio.

As principais fontes de produção de oxigênio estão relacionadas a reaeração atmosférica, fotossíntese e cargas afluentes (tributários). Já a depleção de oxigênio dissolvido (consumo e/ou balanço) está geralmente associada à oxidação bioquímica da matéria orgânica carbonácea e nitrogenada, demanda bentônica, processo de respiração e tributários com menor concentração de oxigênio.

Conhecidas as quantidades produzidas e consumidas de oxigênio, um balanço de massa possibilita a obtenção de uma equação diferencial para o cálculo do teor de oxigênio dissolvido na água. No modelo QUAL2E, a equação diferencial usada para o cálculo de oxigênio dissolvido na água é dada a seguir:

$$
\frac{d C}{d t}=K_{2}\left(C_{S}-C o\right)+\left(\alpha_{3} \mu-\alpha_{4} \rho\right) A_{1}-K_{1} L-K_{4} / H-\alpha_{5} \beta_{1} N_{1}-\alpha_{6} \beta_{2} N_{2}
$$

Onde:

$\mathrm{K}_{2}=$ parâmetro de reaeração, (1/dia);

Cs = concentração de saturação de oxigênio dissolvido em condições locais de temperatura e pressão, $(\mathrm{mg} / \mathrm{L})$;

Co = concentração de oxigênio dissolvido, $(\mathrm{mg} / \mathrm{L})$;

$\alpha_{3}=$ produção de oxigênio por crescimento de algas, $(\mathrm{mg} \mathrm{O}) /(\mathrm{mg} \mathrm{A})$;

$\mu=$ taxa de crescimento de algas, (1/dia);

$\alpha_{4}=$ taxa de consumo de oxigênio por respiração por unidade de algas, $(\mathrm{mg} \mathrm{O} / \mathrm{mg}$ A); 


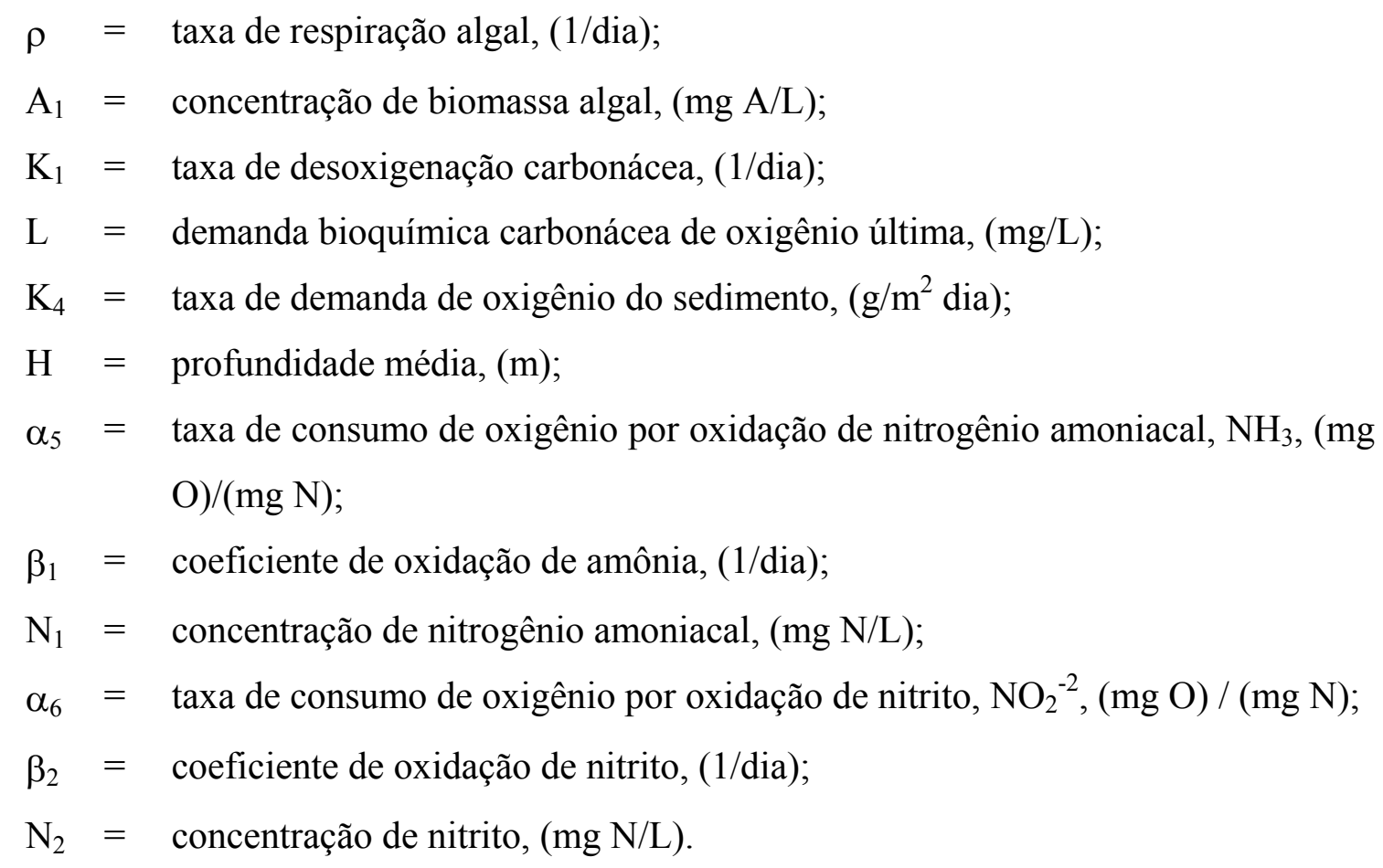

Para a simulação do modelo QUAL2E, caso o usuário desconsidere a fotossíntese, a demanda bentônica de oxigênio e a DBO nitrogenada, os mecanismos de consumo e de introdução de oxigênio no corpo de água ficam reduzidos ao consumo de oxigênio pela DBO carbonácea $\left(K_{1}\right)$ e à passagem de oxigênio atmosférico do ar para a água $\left(\mathrm{K}_{2}\right)$.

Com isso, a equação (3.10) fica:

$$
\frac{d C o}{d t}=K_{2}\left(C_{S}-C o\right)-K_{1} \cdot L
$$

O modelo QUAL2E oferece oito opções para cálculo do parâmetro de reaeração, sendo seis equações citadas na literatura e duas opções para valores medidos de $\mathrm{K}_{2}$. A Tabela 3.6 apresenta as equações citadas na literatura. Nas opções para valores medidos, podese entrar diretamente com os dados do parâmetro ou através do uso dos coeficientes de equação de potência obtida por método de ajuste.

A entrada de dados hidráulicos no modelo QUAL2E auxilia no cálculo do coeficiente de reaeração. Nas equações apresentadas na Tabela 3.6, se observa que o coeficiente de reaeração é diretamente proporcional à velocidade do fluxo e inversamente proporcional à profundidade do corpo hídrico. Quanto maior a velocidade, assim como quanto menor 
a profundidade, maior a área superficial de contato com a atmosfera, logo, maior a taxa de reaeração.

Tabela 3.6 - Equações incorporadas ao modelo QUAL2E para previsão do coeficiente de reaeração, $\mathrm{K}_{2}\left(\mathrm{~d}^{-1}\right)$, a $20{ }^{\circ} \mathrm{C}$.

\begin{tabular}{|l|c|}
\hline \multicolumn{1}{|c|}{ Autores } & Equação no SI \\
\hline O'Connor e Dobbins (1958) & $3,95 \frac{U^{0,5}}{H^{1,5}}$ \\
\hline Churchill e outros (1962) & $5,03 \frac{U^{0,969}}{H^{1,673}}$ \\
\hline Owens e outros (1964) & $5,34 \frac{U^{0,67}}{H^{1,85}}$ \\
\hline Trackston e Krenkel (1969) & $\frac{24,9\left(1+F^{0,5}\right) u^{*}}{H}$ \\
\hline Langbein e Durum (1967) & $5,13 \frac{U}{H^{1,33}}$ \\
\hline Tsivoglou e Wallance (1972) & $86400 . c S U$ \\
\hline
\end{tabular}

$\mathbf{U}=$ velocidade média no trecho, $(\mathrm{m} / \mathrm{s})$

$\mathbf{H}=$ profundidade média no trecho, $(\mathrm{m})$

$\mathbf{S}=$ declividade no trecho, $(\mathrm{m} / \mathrm{m})$

$\mathrm{u}^{*}=$ velocidade de cisalhamento, $(\mathrm{m} / \mathrm{s})$

$\mathbf{F}=$ Número de Froude, (adimensional) $=\mathrm{u}^{*} /(\mathrm{gH})^{0,5}$

$\mathbf{Q}=$ Vazão, $\left(\mathrm{m}^{3} / \mathrm{s}\right)$

g = aceleração da gravidade $\left(\mathrm{m} / \mathrm{s}^{2}\right)$

c = coeficiente de TSIVOGLOU e WALLANCE, $(1 / \mathrm{m})$. Adotado em $0,177 \mathrm{~m}^{-1}$, para vazões na faixa de $0,42 \mathrm{~m}^{3} / \mathrm{s} \leq \mathbf{Q} \leq 84,96 \mathrm{~m}^{3} / \mathrm{s}$

Fonte: BROWN e BARNWELL (1987)

\section{- Concentração de saturação de oxigênio dissolvido}

A concentração de saturação de oxigênio para as condições locais em função da temperatura e da pressão é calculada pelo modelo QUAL2E através da seguinte equação:

$$
\begin{aligned}
\ln C_{S^{\prime}}= & -139,34411+\left(1,575701 \times 10^{5} / T\right)-\left(6,642308 \times 10^{7} / T^{2}\right)+\ldots \\
& \left(1,243800 \times 10^{10} / T^{3}\right)-\left(8,621949 \times 10^{11} / T^{4}\right)
\end{aligned}
$$


Onde:

Cs’ = concentração de oxigênio de equilíbrio, a 1 atmosfera de pressão, (mg/L);

$\mathrm{T}=$ temperatura da água, $\left({ }^{\circ} \mathrm{K}\right)=\left({ }^{\circ} \mathrm{C}\right)+273,15$.

A concentração obtida pela equação (3.14) deverá ser corrigida para a pressão atmosférica local através da equação abaixo:

$$
\mathrm{Cs}=\mathrm{Cs}{ }^{\prime} \times \mathrm{P}
$$

Onde:

Cs $=$ concentração de saturação de oxigênio dissolvido em condições locais de temperatura e pressão, $(\mathrm{mg} / \mathrm{L})$;

$\mathrm{P}=$ pressão atmosférica local, (atm.).

\section{- Dados hidráulicos}

O modelo QUAL2E possui dois métodos de correlação entre velocidade, profundidade e vazão. No primeiro método, utilizam-se coeficientes de descarga, Equações 3.15.a (velocidade), 3.15.b (área) e 3.15.c (profundidade). O segundo método é calculado através de dados de levantamentos topobatimétricos, relacionados à profundidade do canal e a forma da seção transversal, aproximando-a de um trapézio. Conhecidos os valores da inclinação lateral, largura e a declividade do canal, a velocidade média no trecho pode ser obtida através da fórmula de Manning.

$$
\begin{aligned}
\mathrm{U} & =\mathrm{aQ}^{\mathrm{b}} \\
\mathrm{A} & =\mathrm{Q} / \mathrm{U} \\
\mathrm{H} & =\alpha \mathrm{Q}^{\beta}
\end{aligned}
$$

Onde $a, b, \alpha$, e $\beta$ são constantes empíricas (dados de entrada), obtidas por métodos de ajuste com os dados de campo correspondentes a cada trecho do segmento fluvial. 


\subsubsection{Estrutura conceitual e alocação de cargas}

A estrutura conceitual do modelo QUAL2E consiste na idealização de um protótipo para um sistema hídrico unidimensional ramificado. Este sistema é subdividido em trechos com características hidráulicas semelhantes, e estes trechos são subdivididos em elementos de igual comprimento, caracterizando a base de entrada de dados do sistema. Figura 3.2.

Cada elemento no modelo QUAL2E pode ter uma única designação. O modelo classifica os elementos computacionais em sete tipos, dados por:

1 - Elemento de cabeceira (primeiro elemento do curso principal dos afluentes);

2 - Elemento padrão (aquele que não se enquadra em nenhum dos outros tipos);

3 - Elemento anterior a uma junção (último do curso principal antes de um afluente);

4 - Elemento de junção (elemento do curso principal que recebe entrada de um afluente);

5 - Elemento final do sistema fluvial simulado;

6 - Elemento que recebe um lançamento;

7 - Elemento onde ocorre captação de água.

A alocação das cargas no modelo QUAL2E pode ser feita de forma pontual, caracterizando a poluição pontual, ou distribuída, caracterizando a poluição difusa, sendo que ambas admitem apenas o regime permanente de vazão. Os incrementos de vazão, que podem ou não caracterizar a poluição difusa, são constantes para cada trecho em particular.

Para alocação da carga de DBO, a concentração do poluente no efluente não pode ser superior a $1000 \mathrm{mg} / \mathrm{L}$. 


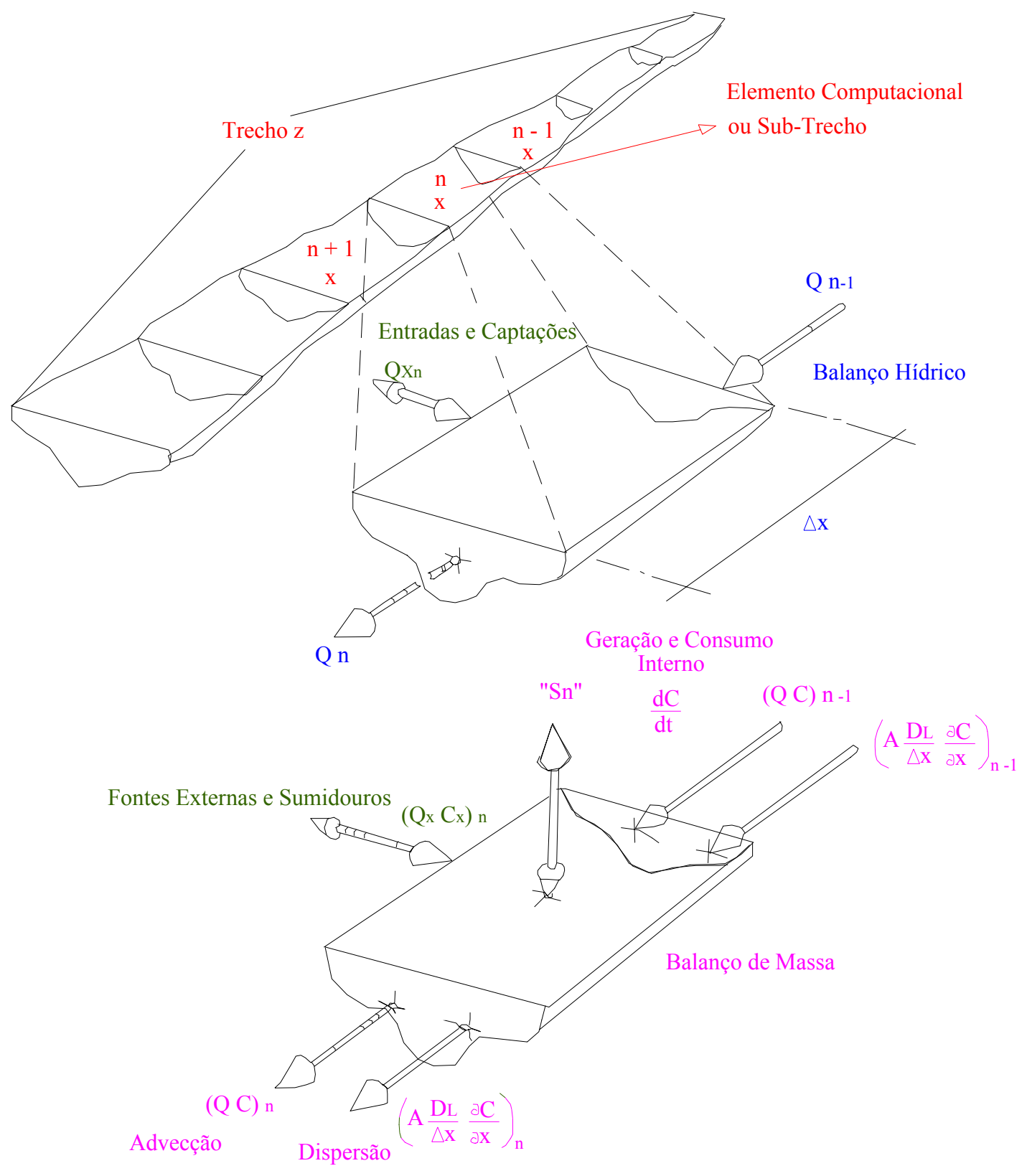

Fonte: BROWN e BARNWELL (1987)

Figura 3.2 - Esquema de um protótipo para um sistema hídrico ramificado 


\subsection{Modelo de outorga e cobrança pelo uso da água RM1}

O texto apresentado nesse item foi extraído da dissertação Metodologia de apoio à concessão de outorga para lançamento de efluentes e cobrança pelo uso da água - O modelo RM1, de ROBERTA BAPTISTA RODRIGUES, São Paulo, 2000.

\subsubsection{Características do modelo}

O modelo de outorga e cobrança pelo uso da água RM1 (RODRIGUES, 2000) pode servir de base para aplicação da Lei 9.433, da Resolução n ${ }^{\circ}$, da Resolução ${ }^{\circ} 48$ e da Resolução $n^{\circ} 357$.

Através do modelo RM1, o usuário da água paga pelo efetivo uso dela tanto para lançamento como para captação, considerando a capacidade de autodepuração do corpo hídrico, a Classe de Uso, a vazão do corpo hídrico, a qualidade da água captada, os prejuízos, em termos de qualidade da água, ocasionados pelos usuários-poluidores de montante aos usuários de jusante. Assim, o modelo RM1 torna possível a articulação dos instrumentos de gestão dentro do contexto de gestão integrada.

O modelo RM1 determina a variação longitudinal da vazão de diluição, a vazão liberada no sistema para novas outorgas e o volume de diluição da carga de poluente do usuário de montante captada pelo usuário de jusante, referente apenas ao lançamento e ao poluente considerados. RODRIGUES (2000)

No modelo RM1 isto é possível através da separação de quanto efetivamente cada usuário-poluidor contribui individualmente num conjunto de lançamentos de poluentes ao longo do corpo receptor. RODRIGUES (2000)

O cálculo da vazão de diluição da carga de poluente retirada do corpo hídrico, referente a cada usuário-poluidor, permitiu, a partir deste trabalho, que o custo da respectiva vazão fosse repassado ao respectivo usuário-poluidor e subtraído do custo da respectiva captação, viabilizando a criação de um novo conceito para o processo de gestão de recursos, o de Justiça Hídrica. Logo, quanto melhor a qualidade da água captada, maior 
o custo para a captação; assim como para lançamento, quanto maior os danos provocados aos usuários de jusante, maior o custo de lançamento do respectivo efluente.

\subsubsection{Estrutura conceitual}

A técnica de solução numérica utilizada pelo modelo é baseada na determinação dos valores espaciais de uma variável no passo de tempo $n+1$, conhecida sua distribuição espacial no passo de tempo anterior $\mathrm{n}$, sendo o passo de tempo zero correspondente às condições iniciais do sistema, técnica semelhante a do modelo QUAL2E. A Figura 3.3 apresenta uma representação esquemática do modelo RM1.

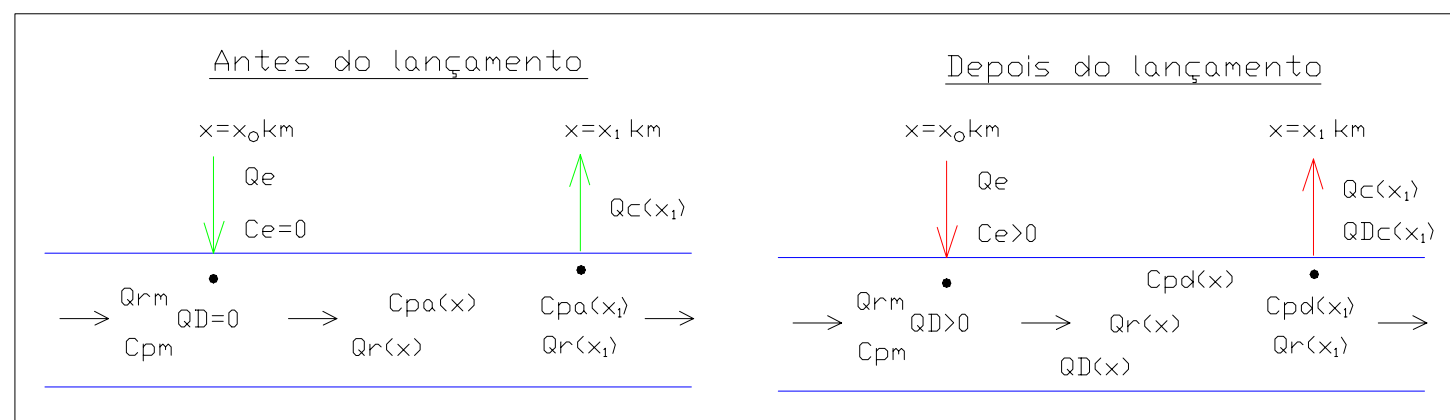

$\mathrm{Cpm}$ - concentração do poluente imediatamente a montante do ponto de lançamento do efluente

Qrm - vazão do rio imediatamente a montante do ponto de lançamento do efluente

Ce - concentração do poluente no efluente

Cpd - concentração do poluente no corpo receptor após o lançamento do efluente

Cpa - concentração do poluente no corpo receptor antes do lançamento do efluente, diluída na vazão do efluente

Qc - vazão de captação

QDc - vazão de diluição da carga de poluente retirada através de captação

Qr - vazão do rio

Fonte: RODRIGUES (2000)

Figura 3.3 - Representação esquemática do modelo RM1

\subsubsection{Equações do modelo RM1}

\section{- Variação longitudinal da vazão de diluição $Q D(x)$}

O cálculo da variação longitudinal da vazão de diluição, para lançamento de poluentes em rios, é fornecido através da seguinte equação:

$$
Q D(x)=\frac{1}{C_{P^{*}}(x)} .\{[C p d(x)-C p a(x)][Q R r(x)+Q e]\}
$$


Onde:

$\mathrm{QD}(\mathrm{x})=$ vazão de diluição do poluente, referente apenas ao lançamento do usuáriopoluidor considerado, $\left(\mathrm{m}^{3} / \mathrm{s}\right)$;

$\mathrm{Cp}^{*}(\mathrm{x})=$ concentração máxima permissível do poluente no corpo receptor, que poderá resultar do enquadramento do corpo hídrico em classe de uso ou de um plano de recuperação da bacia, $(\mathrm{mg} / \mathrm{L})$;

$\operatorname{Cpd}(\mathrm{x})=$ concentração do poluente no corpo receptor após o lançamento do efluente, $(\mathrm{mg} / \mathrm{L})$

$\mathrm{Cpa}(\mathrm{x})=$ concentração do poluente no corpo receptor antes do lançamento do efluente, diluída na vazão do efluente, $(\mathrm{mg} / \mathrm{L})$;

$\operatorname{Qr}(\mathrm{x})=$ vazão do corpo receptor, $\left(\mathrm{m}^{3} / \mathrm{s}\right)$;

Qe $=$ vazão de lançamento do efluente no corpo receptor, $\left(\mathrm{m}^{3} / \mathrm{s}\right)$.

\section{- Vazão liberada para novas outorgas $Q_{L}(x)$}

Para que a classe de uso do corpo receptor seja mantida, a seguinte relação deve ser respeitada:

$$
Q_{L}(x)=[Q r(x)+Q e]\left[1-\frac{C p d(x)}{C p^{*}(x)}\right]
$$

Onde:

$\mathrm{Q}_{\mathrm{L}}(\mathrm{x})=$ vazão de diluição liberada para novas outorgas, $\left(\mathrm{m}^{3} / \mathrm{s}\right)$.

\section{- Vazão liberada por lançamento $Q_{L L}(x)$}

Representa o quanto de vazão de diluição o usuário-poluidor está deixando de pagar, considerando o processo de autodepuração. Este cálculo é expresso através da seguinte equação:

$$
Q_{L L}(x)=[Q r(x)+Q e] .\left[1-\frac{C p d(x)-C p a(x)}{C p^{*}(x)}\right]
$$

Onde:

$\mathrm{Q}_{\mathrm{LL}}(\mathrm{x})=$ vazão de diluição liberada por lançamento, $\left(\mathrm{m}^{3} / \mathrm{s}\right)$. 


\section{- Vazão de diluição da carga de poluente retirada através de captações $Q D c(x)$}

A vazão de diluição da carga de poluente retirada através de captação, referente apenas ao lançamento do usuário-poluidor considerado, é dada por:

$$
Q D c(x)=\frac{[C p d(x)-C p a(x)]}{C p^{*}(x)} \cdot Q c(x)
$$

Onde:

QDc(x) = vazão de diluição da carga de poluente retirada através de captação, referente apenas ao lançamento do efluente do usuário-poluidor considerado, $\left(\mathrm{m}^{3} / \mathrm{s}\right)$;

$\mathrm{Qc}(\mathrm{x})=$ vazão de captação, $\left(\mathrm{m}^{3} / \mathrm{s}\right)$.

\subsubsection{Condições a serem respeitadas}

a) A vazão do corpo receptor será considerada constante para o respectivo trecho de lançamento. Caso haja acréscimo na vazão do rio, devido ao incremento proporcionado pela área de drenagem, esta passará a ser considerada;

b) Para que o regime de vazão do corpo receptor antes do lançamento do efluente seja igual ao regime de vazão após o lançamento do mesmo, é necessário que, na simulação de decaimento da concentração do poluente já existente no sistema, seja inserida a vazão de lançamento do efluente no ponto de seu lançamento e mantido os pontos de captação de jusante;

c) A análise de cada lançamento de efluente no corpo receptor será considerada separadamente aos demais lançamentos a jusante;

d) A vazão do efluente será considerada como constante;

e) As características hidráulicas de cada trecho do sistema devem ser respeitadas, assim como os coeficientes de reaeração $\left(\mathrm{K}_{2}\right)$, desoxigenação $\left(\mathrm{K}_{1}\right)$ e sedimentação $\left(\mathrm{K}_{3}\right)$, de cada trecho.

O modelo RM1 deve ser aplicado com o auxílio de um modelo matemático de qualidade da água, devidamente calibrado para a bacia em estudo, para obtenção da curva de decaimento da concentração do poluente no rio, antes $(\mathrm{Cpa}(\mathrm{x}))$ diluída na vazão do efluente, e após $(\mathrm{Cpd}(\mathrm{x}))$ o lançamento do efluente no corpo receptor. 


\subsubsection{Determinação do valor a ser pago pelo usuário-poluidor, considerando os} danos ocasionados na qualidade da água captada

O custo médio a ser pago pelo usuário para lançamento de seu efluente no corpo receptor, não considerando a qualidade da água captada, é dado por:

$$
\bar{C} \$=\frac{C \$ \cdot \sum_{0}^{i} V D\left(x_{i}\right) \cdot C p d\left(x_{i}\right)}{\sum_{0}^{i} C p d\left(x_{i}\right)}
$$

Onde:

$\bar{C} \$=$ custo médio a ser pago pelo usuário-poluidor para lançamento do efluente no corpo receptor, não considerando a qualidade da água captada, $\left(\mathrm{R} \$ / \mathrm{m}^{3}\right)$;

$\mathrm{VD}(\mathrm{x})=$ volume de diluição do poluente no corpo receptor, referente apenas ao lançamento do usuário-poluidor considerado, $\left(\mathrm{m}^{3}\right)$;

$\mathrm{C} \$=$ custo unitário por $\mathrm{m}^{3}$ de água locado no corpo receptor, $\left(\mathrm{R} \$ / \mathrm{m}^{3}\right)$;

$\mathrm{i}=$ espaço, $(\mathrm{km})$.

Já o custo total para lançamento do efluente do usuário-poluidor, considerando os dados ocasionados na qualidade da água captada, é dado por:

$$
C \$_{\text {Total }}=\frac{C \$ \cdot \sum_{0}^{i} V D\left(x_{i}\right) \cdot C p d\left(x_{i}\right)}{\sum_{0}^{i} \operatorname{Cpd}\left(x_{i}\right)}+C \$ \cdot \sum_{0}^{k} \operatorname{VDc}\left(x_{k}\right)
$$

Onde:

$\mathrm{C}_{\text {Total }}=$ custo total a ser pago pelo usuário-poluidor para lançamento do efluente no corpo receptor, considerando os danos ocasionados na qualidade da água captada, $(\mathrm{R} \$)$;

$\operatorname{VDc}(\mathrm{x})=$ volume de diluição da carga de poluente retirada através de captação, referente apenas ao lançamento do efluente do usuário-poluidor considerado, $\left(\mathrm{m}^{3}\right)$;

$\mathrm{k}=$ ponto de captação que sofre interferência na qualidade de suas águas, devido ao lançamento do efluente do usuário-poluidor de montante considerado, (adimensional). 


\subsubsection{Determinação do valor a ser pago pelo usuário de captação, considerando a qualidade da água captada}

O custo total de captação do usuário é representado por:

$$
C c \$_{\text {Total }}=C c \$ . V c(x)-\sum_{0}^{g^{*}} C \$ . V D_{c}(x)
$$

$\mathrm{Cc} \$_{\text {Total }}=$ custo total da vazão captada, considerando a qualidade da água captada, $(\mathrm{R} \$)$;

$\mathrm{Cc} \$=$ custo unitário por $\mathrm{m}^{3}$ de água captada, $\left(\mathrm{R} \$ / \mathrm{m}^{3}\right)$;

$\mathrm{g}^{*} \quad=$ usuário-poluidor de montante que prejudica o ponto de captação de jusante considerado, (adimensional).

A partir deste trabalho, a quantificação pelo modelo RM1 da carga de poluente retirada do rio através de pontos de captação, referente a cada usuário-poluidor de montante, permitiu, que o custo da vazão de diluição da carga de poluente retirada do rio fosse repassado ao respectivo usuário-poluidor e subtraído do custo da respectiva captação. Logo, quanto maior os danos, em termos de qualidade da água e com relação as variáveis simuladas, provocados aos usuários de jusante, maior o custo de lançamento do usuário-poluidor, assim como, quanto pior a qualidade da água captada, menor o custo para a captação.

RODRIGUES (2000) aplicou o modelo RM1 na bacia do rio Jundiaí, São Paulo, e fez uma análise comparativa entre a aplicação do modelo RM1 e a aplicação direta da Lei 9.433 e da Metodologia proposta pelo Conselho Estadual de Recursos Hídricos do Estado de São Paulo.

\subsection{Modelagem do sistema de suporte a decisão RB}

Sistemas de Suporte a Decisão são sistemas computadorizados que auxiliam a tomada de decisões a respeito de problemas complexos. É importante definir o problema a ser solucionado e os fatores envolvidos. 
O Sistema de Suporte a Decisão RB para oferecer subsídios para conceder a outorga solicitada e calcular o custo de lançamento e/ou captação na bacia leva em consideração uma série de fatores, tais como:

- Localização da outorga solicitada na rede hidrográfica;

- Disponibilidade de água no local solicitado;

- $\quad$ Qualidade da água no local solicitado;

- Enquadramento do rio no local de outorga solicitada;

- Grau de prejuízo do lançamento do usuário-poluidor aos usuários de jusante;

- Quantidade de água solicitada;

- Localização das outorgas já concedidas na rede hidrográfica;

- Usos da água a montante e a jusante do local em estudo;

- $\quad$ Série histórica de dados qualitativos e quantitativos da bacia hidrográfica;

- Características hidráulicas do corpo hídrico;

- Capacidade de autodepuração do corpo hídrico;

- Associação do custo total da água captada à qualidade da água no ponto de captação, ou seja, quanto melhor a qualidade da água captada mais o usuário paga, assim como quanto mais degradada a qualidade da água menos o usuário paga;

- Associação do custo de lançamento do usuário-poluidor aos prejuízos ocasionados aos usuários de jusante, em termos de qualidade da água.

Com base nas considerações acima, o SSD RB quantifica os custos referentes à captação e lançamento, levando em consideração a qualidade e a quantidade da água, assim como o prejuízo ocasionado pelo usuário-poluidor aos usuários de jusante e as conseqüências de uma captação expressiva na qualidade da água de jusante.

Dentro do contexto de gestão de bacia hidrográfica, também devem ser levados em consideração pelo especialista em recursos hídricos os seguintes aspectos:

- Critérios de outorga;

- Normas e legislações estaduais e/ou federal sobre aproveitamento de recursos hídricos;

- Política de recuperação e/ou preservação da bacia hidrográfica;

- $\quad$ Prioridades de uso estabelecidas na bacia hidrográfica. 
O SSD RB tem por objetivo integrar aos processos de análise de outorga e cobrança pelo uso da água aspectos de qualidade da água, tanto no que se refere à outorga de lançamento como às outorgas de usos quantitativos, tratando as mesmas a partir da mesma variável de decisão, ou seja, volume outorgado.

No SSD RB, através do modelo RM1, são quantificadas:

- Vazão de diluição ao longo do rio por lançamento, QD(x);

- Vazão liberada no rio por lançamento, $\mathrm{Q}_{\mathrm{LL}}(\mathrm{x})$;

- Vazão liberada no rio para novas outorgas, $\mathrm{Q}_{\mathrm{L}}(\mathrm{x})$;

- Vazão de diluição da carga de poluente retirada do rio através de captações, $\mathrm{QDc}(\mathrm{x})$;

- Custo por lançamento considerando o grau de poluição ocasionado aos usuários de jusante, $\mathrm{C} \$_{\text {TOTAL }}$;

- $\quad$ Custo por captação considerando o grau de poluição da água captada, $C c \$_{\text {TOTAL }}$.

Na modelagem do SSD RB ocorre a integração dos modelos QUAL2E e RM1, visando a simulação de rios e/ou trechos de rios através de cenários distintos de vazões inseridos pelo usuário, que podem ser provenientes do tratamento de dados da série histórica de postos pluviométricos e/ou fluviométricos, ou de vazões liberadas através da política de operação de reservatórios.

Segundo PORTO (2001): “A necessidade de autorização para disposição de resíduos líquidos nos corpos de água superficiais decorre do reconhecimento de que não é possível eliminar todas as descargas de poluentes no meio ambiente, isto é, não existe tratamento de efluentes com $100 \%$ de eficiência. A descarga será sempre necessária e, portanto, deve ser disciplinada. A outorga por volume de diluição para lançamentos de esgoto e demais resíduos líquidos é um dos instrumentos para o estabelecimento dessa disciplina".

Segundo PORTO (2001): “A quantidade de poluentes que pode ser autorizada para lançamento no meio ambiente deve ser tal que não cause mudanças na classe do corpo receptor, isto é, que fique dentro daquela "degradação" prevista para a classe. Está 
sendo utilizada assim a chamada capacidade assimilativa do corpo receptor. Esta capacidade assimilativa pode ser definida como sendo a "distância" entre a condição do corpo receptor a montante do lançamento e o padrão da classe daquele trecho".

A principal função do SSD RB é, então, analisar todos os fatores envolvidos e oferecer subsídios que auxiliem a tomada de decisão na totalidade dos processos de outorga e cobrança por parte da autoridade competente.

A estrutura do SSD aqui proposto é constituída por uma Interface Gráfica, uma Base de Dados e dois modelos: QUAL2E e RM1. A Figura 3.4 apresenta a estrutura do SSD RB.

O SSD RB visa o processo de gestão de um rio em quantidade e qualidade, já que a integração dos mesmos proporciona quantificar a colaboração individual do usuário na poluição de um rio ao longo do corpo receptor, e também responde sobre a implicação da inserção de novos pontos de captação e lançamento ao longo do corpo receptor através de cenários diversificados de vazão.

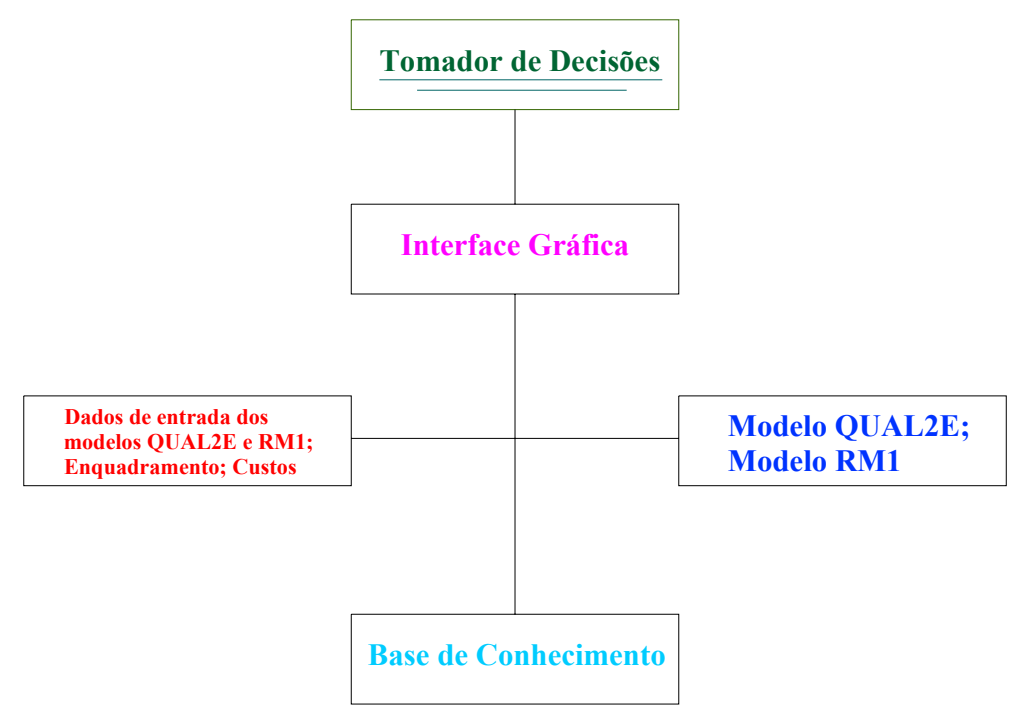

Figura 3.4 Estrutura do SSD RB

Os cálculos realizados pelo SSD RB são efetuados mediante cenários diversificados de vazão. Neste sistema, são permitidos até 20 cenários de vazão. A diversificação de regimes de vazão para um mesmo cenário de lançamentos e captações de um rio proporciona uma avaliação da qualidade da água para os mais diversos regimes a que o rio pode ser submetido, assim como uma análise qualitativa e quantitativa de 
lançamentos e captações para auxiliar os processos de outorga e cobrança pelo uso da água.

No SSD RB é possível trabalhar com 20 cenários de dados de entrada para a vazão, assim como, é possível também trabalhar com 20 cenários de dados de entrada para:

- $\quad$ Dados de Condição Inicial do Rio;

- Custos Unitários;

- $\quad$ Classe de Uso;

- Dados Hidráulicos;

- $\quad$ Parâmetros e Coeficientes;

- $\quad$ Dados de Cabeceira;

- Poluição Difusa.

Trabalhar com cenários diversificados para os dados acima permite a combinação entre os mesmos, facilitando também o processo de calibração do sistema. A combinação entre cenários, através do SSD RB, é possível porque em um único arquivo de entrada de dados do sistema, para cada cenário, é inserido um conjunto de dados pertinente ao mesmo. Os cálculos realizados pelos modelos RM1 e QUAL2E são realizados distintamente para cada cenário, possibilitando, na saída do sistema, uma análise comparativa entre os resultados obtidos para cada cenário simulado.

A estrutura geral do sistema é representada graficamente através da Figura 3.5, com o objetivo de oferecer uma melhor visualização do funcionamento do sistema no que diz respeito à entrada e saída de dados. Os dados inseridos através da Interface Gráfica são armazenados na Base de Dados e acessados através de rotinas do SSD conforme a necessidade do sistema. Os dados de entrada do SSD RB são:

- $\quad$ Dados de entrada do modelo QUAL2E;

- $\quad$ Série de dados de vazões a ser simulada;

- Enquadramento do corpo hídrico;

- Valores máximos permissíveis no rio adotados para os poluentes simulados, o que vai depender da política de recuperação e preservação da bacia hidrográfica;

- Custos unitários para captação e para diluição. 


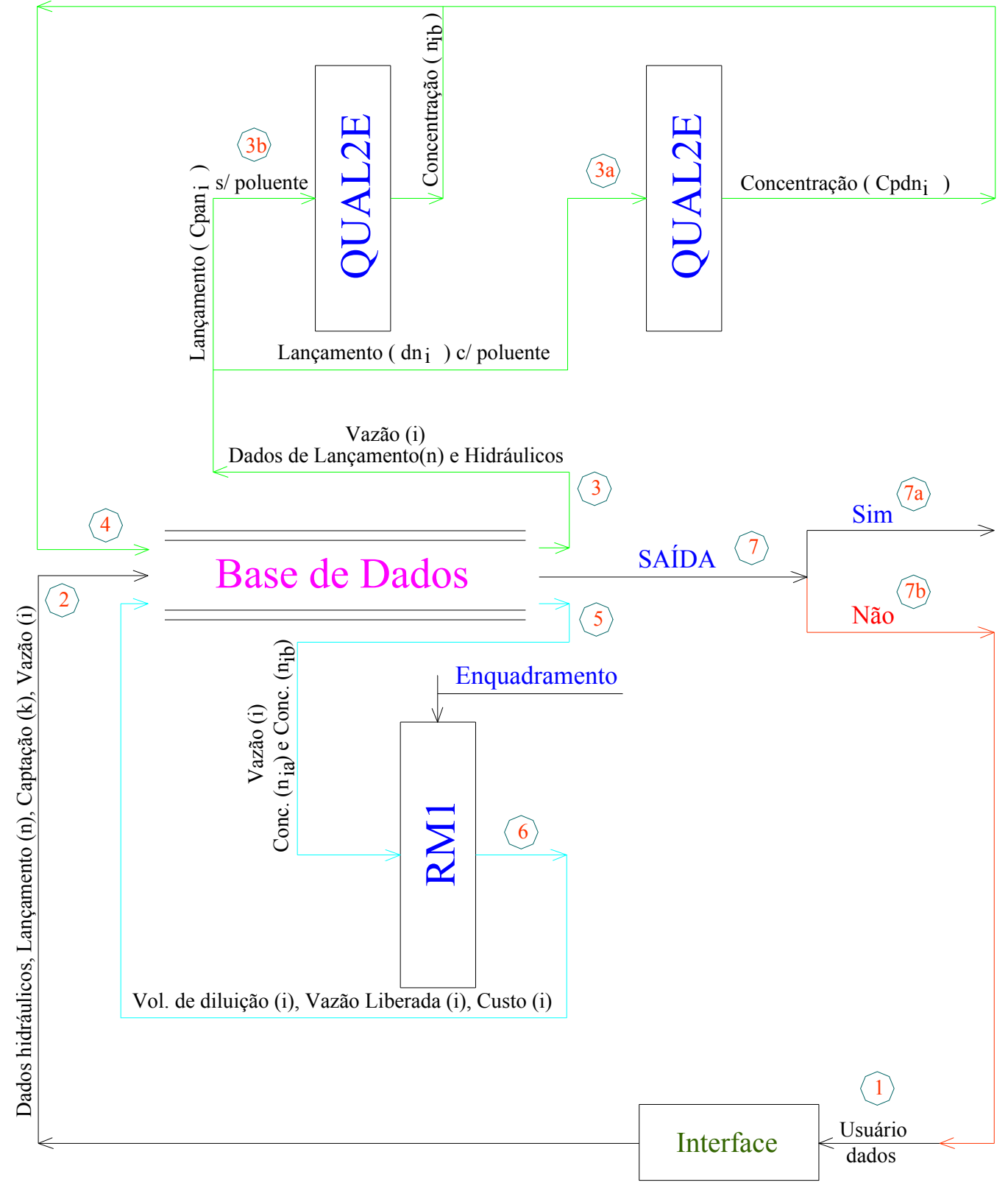

Figura 3.5 - Fluxograma de dados do SSD RB 
Cada valor de vazão simulado deve estar associado aos respectivos parâmetros de calibração.

O modelo QUAL2E é simulado duas vezes para cada ponto de lançamento, e para cada regime de vazão, ou seja, caso haja dez diferentes valores de vazão e dez pontos de lançamento no rio, o modelo QUAL2E será rodado 200 vezes para alimentar o modelo RM1. Como já explicado no item 3.4.4, porque para que o regime de vazão do corpo receptor antes do lançamento do efluente seja igual ao regime de vazão após o lançamento do mesmo, é necessário que, na simulação de decaimento da concentração do poluente já existente no sistema, seja inserida a vazão de lançamento do efluente no ponto de seu lançamento e mantido os pontos de captação de jusante. (Ver Figura 3.5)

A integração dos modelos QUAL2E e RM1 permite a gestão em quantidade e qualidade dos processos de outorga e cobrança pelo uso da água, porque leva em consideração o regime de vazão, o enquadramento e a capacidade de autodepuração do corpo hídrico.

A seguir é realizada uma descrição detalhada sobre o funcionamento da Base de Dados e dos modelos QUAL2E e RM1 para o funcionamento do SSD RB. É abordada também a linguagem de programação utilizada para o desenvolvimento do sistema.

\subsubsection{Função do modelo QUAL2E}

O modelo de qualidade das águas QUAL2E tem como função calcular a concentração do poluente ao longo do eixo principal do rio. Para o modelo QUAL2E os dados de vazão do corpo receptor são calculados através de um único valor de vazão. O SSD QUA2R2 permite que o modelo QUAL2E seja rodado diversas vezes para valores de vazão.

Os dados de entrada do modelo QUAL2E são: dados de lançamento (localização, vazão de lançamento, concentração de poluente), dados de captação (localização, vazão), dados de vazão e concentração do poluente no corpo receptor, e dados dos parâmetros de calibração do modelo. Para o SSD RB é permitido ao usuário entrar com valores dos parâmetros de calibração associados aos respectivos valores de vazão simulados, facilitando o processo de calibração. 
A função principal do modelo QUAL2E no SSD RB é a de calcular a concentração do poluente diante de um cenário global de lançamentos e captações. Os dados calculados pelo Modelo QUAL2E são lidos e enviados posteriormente ao modelo RM1.

\subsubsection{Função do modelo RM1}

O modelo RM1 tem como função calcular a vazão de diluição no rio e a vazão de diluição da carga de poluente retirada do rio através de captações, para cada usuário, lançamento e poluente, assim como a vazão de diluição liberada no sistema para novas outorgas.

O modelo RM1 considera o decaimento da concentração de poluente no sistema, utilizando como ferramenta de auxílio o modelo QUAL2E para considerar os processos de degradação, sedimentação e diluição do poluente no sistema. Isto é possível através da separação pelo modelo RM1 de quanto efetivamente cada usuário-poluidor contribui em carga de poluição ao longo do corpo receptor.

Através do modelo RM1, é possível responder sobre a implicação de lançamentos na qualidade da água captada a jusante. Logo, é possível repassar o custo da vazão de diluição da carga de poluente retirada do sistema por pontos de captação aos respectivos usuários de montante, assim como amortecer esses valores no custo de captação dos usuários atingidos por lançamentos de montante. Assim, quando mais limpo o rio, mais o usuário paga para captar, assim como quanto maior forem os prejuízos causados aos usuários de jusante pelo usuário-poluidor, maior será o custo de seu lançamento.

Os dados calculados pelo modelo RM1, considerando o processo de autodepuração, o enquadramento e o regime de vazão do corpo hídrico, são:

- Vazão de diluição ao longo do rio por lançamento, QD(x);

- Vazão liberada no rio por lançamento, $\mathrm{Q}_{\mathrm{LL}}(\mathrm{x})$;

- Vazão liberada no rio para novas outorgas, $\mathrm{Q}_{\mathrm{L}}(\mathrm{x})$;

- Vazão de diluição da carga de poluente retirada do rio através de captações, QDc(x);

- Custo por lançamento considerando o grau de poluição ocasionado aos usuários de 
jusante, $\mathrm{C} \$_{\mathrm{TOTAL}}$;

- Custo por captação considerando o grau de poluição da água captada, Cc\$TOTAL.

\subsubsection{Função da base de dados}

A Base de Dados é constituída por arquivos textos que armazenam os dados de entrada (número de trechos, comprimento do elemento, comprimento do trecho, elemento de cabeceira, captação, lançamento, reservatório, vazões, enquadramento, custos, etc.), assim como por arquivos do modelo QUAL2E. Os dados calculados pelo modelo RM1 ficam disponíveis em modo de execução (Versão 1.00).

\subsubsection{Interface gráfica do SSD RB}

A Interface Gráfica do sistema RB, na medida do possível, procura ser didática e clara nos processos de entrada e saída de dados. Para os dados de entrada do modelo QUAL2E, a interface procura não descaracterizar em excesso a disposição de entrada de dados da interface gráfica do modelo QUAL2E oferecida pela USEPA (1995), visando dessa forma uma maior aceitação do sistema por parte do usuário.

Os dados calculados pelos modelos QUAL2E e RM1 são apresentados de forma tabular e gráfica ao usuário, mediante opção por cenários simulados, variáveis simuladas, lançamentos.

Com a liberação dos dados pelo SSD RB, é possível analisar graficamente, para cenários distintos de vazões, a qualidade das águas do rio e a disponibilidade das mesmas para novos lançamentos e captações, assim como fazer uma análise para as solicitações de outorga, tanto em termos de qualidade e quantidade da água como em termos de custos.

\subsubsection{Linguagem de programação do sistema}

O modelo QUAL2E foi desenvolvido na linguagem de programação ANSI FORTRAN 77. O SSD RB foi desenvolvido em linguagem de programação VISUAL BASIC 6. O 
arquivo de entrada é criado, assim como o arquivo de saída é lido, em linguagem VISUAL BASIC 6.

\subsection{Articulação do SSD RB com os instrumentos de gestão}

O SSD RB possibilita a articulação dos instrumentos de gestão da Política Nacional de Recursos Hídricos, apoiada na diretriz de gestão integrada de recursos hídricos, sem dissociação dos aspectos de quantidade e qualidade.

Através do SSD RB, a gestão quali-quantitativa dos processos de outorga e cobrança pelo uso da água pode abranger de forma articulada os instrumentos da Política Nacional de Recursos Hídricos: Plano de Recursos Hídricos; enquadramento dos corpos d'água em suas respectivas classes de uso; e Sistema de Informações sobre Recursos Hídricos. (Ver Figura 3.6)

Após a alimentação e calibração do SSD RB com as respectivas informações, o SSD RB surge como um instrumento de planejamento econômico, na medida que oferece formas eficazes de valorar os recursos hídricos, podendo contribuir para a preservação e reversão da degradação ambiental, garantindo quantidade de água de boa qualidade para múltiplos usos.

Para que o planejamento e gerenciamento de recursos hídricos sejam exercidos de forma consistente e eficaz, existe a necessidade, acima de tudo, de um conjunto de informações da bacia e da região em estudo, assim como informações dos respectivos usuários, possibilitando o tratamento dessas informações por sistemas de articulação de dados que gerem subsídios para o desenvolvimento de estudos confiáveis e tomadas de decisões mais rápidas e precisas, como por exemplo, o SSD RB aqui apresentado. Logo, o sucesso do Sistema de Informações de Recursos Hídricos é de vital importância para a efetiva aplicação da Política Nacional de Recursos Hídricos. 


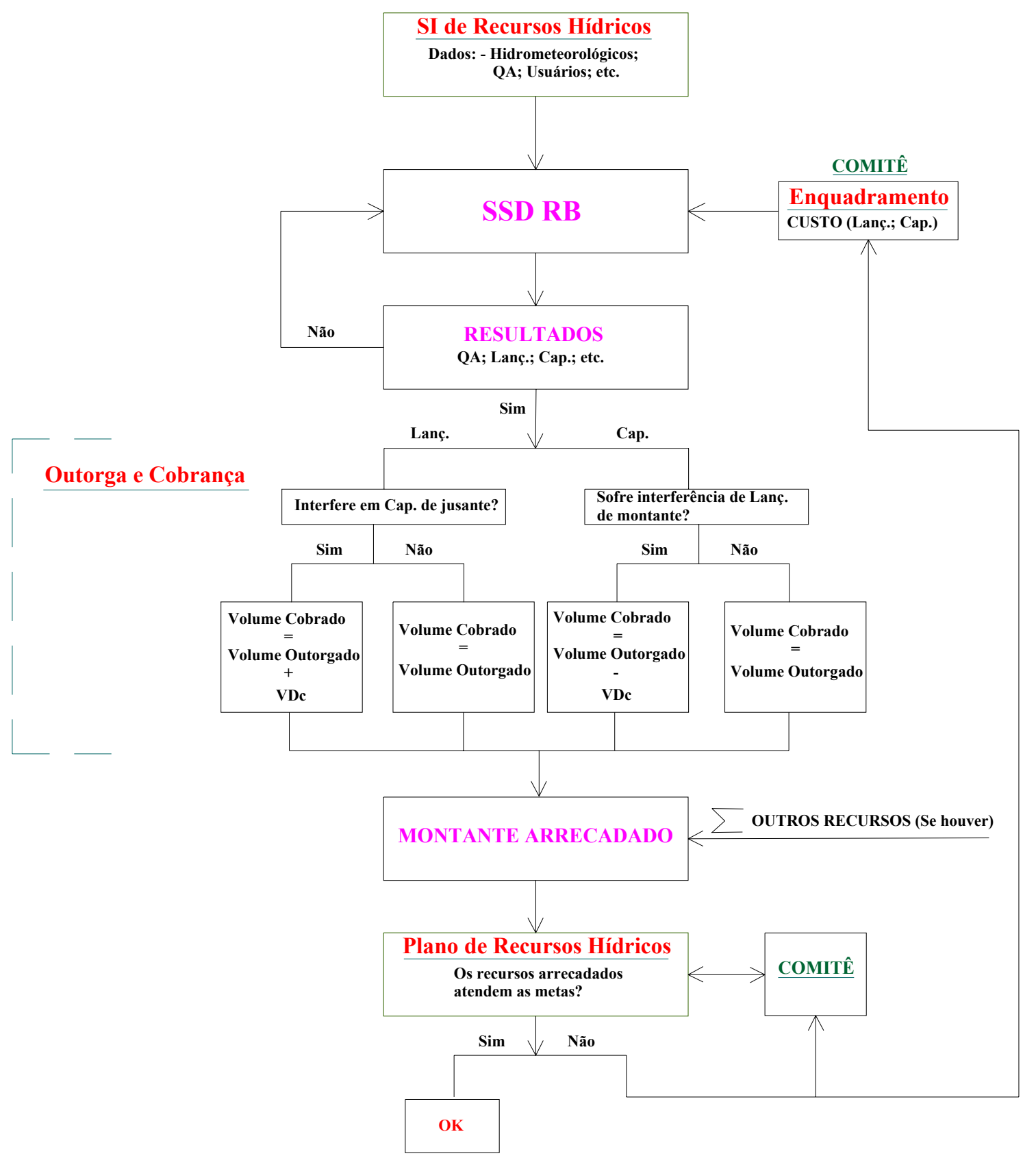

QA - Qualidade da água

VDc - Volume de diluição da carga de poluente retirada do rio através de captação

Figura 3.6 - Uso do SSD RB articulado com os instrumentos de gestão 


\section{Capítulo 4}

\section{ESTUDO DA BACIA DO RIO JUNDIAÍ PARA APLICAÇÃO DO SSD RB}

\subsection{Bacia do rio Jundiaí}

O texto deste item foi adaptado do trabalho de RODRIGUES (2000), que estudou a bacia do rio Jundiaí para aplicação do modelo RM1.

A Bacia do rio Jundiaí localiza-se no Estado de São Paulo, compreendida entre as coordenadas $46^{\circ} 30^{\prime}$ e $47^{\circ} 17^{\prime}$ de longitude a oeste do meridiano de Greenwich e $23^{\circ}$ $20^{\prime}$ e $23^{\circ} 02^{\prime}$ de latitude ao sul do Equador. Possui uma área de aproximadamente 1.150 $\mathrm{km}^{2}$, onde estão localizados os municípios de Campo Limpo Paulista, Várzea Paulista, Jundiaí, Itupeva, Cabreúva, Indaiatuba e Salto (CETESB, 2001). (Figuras 4.1, 4.2 e 4.3)

A bacia hidrográfica está situada no contato do Planalto Cristalino Atlântico, de relevo montanhoso (superior a 800 metros de altitude), na Serra dos Cristais, com a Depressão Periférica que apresenta colinas suaves em torno de 600 metros de altitude, esculpidas em sedimentos Paleozóicos. (CETESB, 1981)

O solo apresenta-se com $38,5 \%$ de sua área ocupada com pastagem natural e cultivada, $10 \%$ com áreas de reflorestamento, e 9\% com matas e capoeiras. Apresenta atividades agrícolas com predomínio de frutas, citrus, hortaliças, tomate, batata, etc; atividade granjeira, uso urbano e acentuado desenvolvimento industrial. Esta bacia abrange as 
áreas declaradas por decretos estatuais como Áreas de Proteção Ambiental de Jundiaí, Cabreúva e Várzea Paulista. (CETESB, 2001)

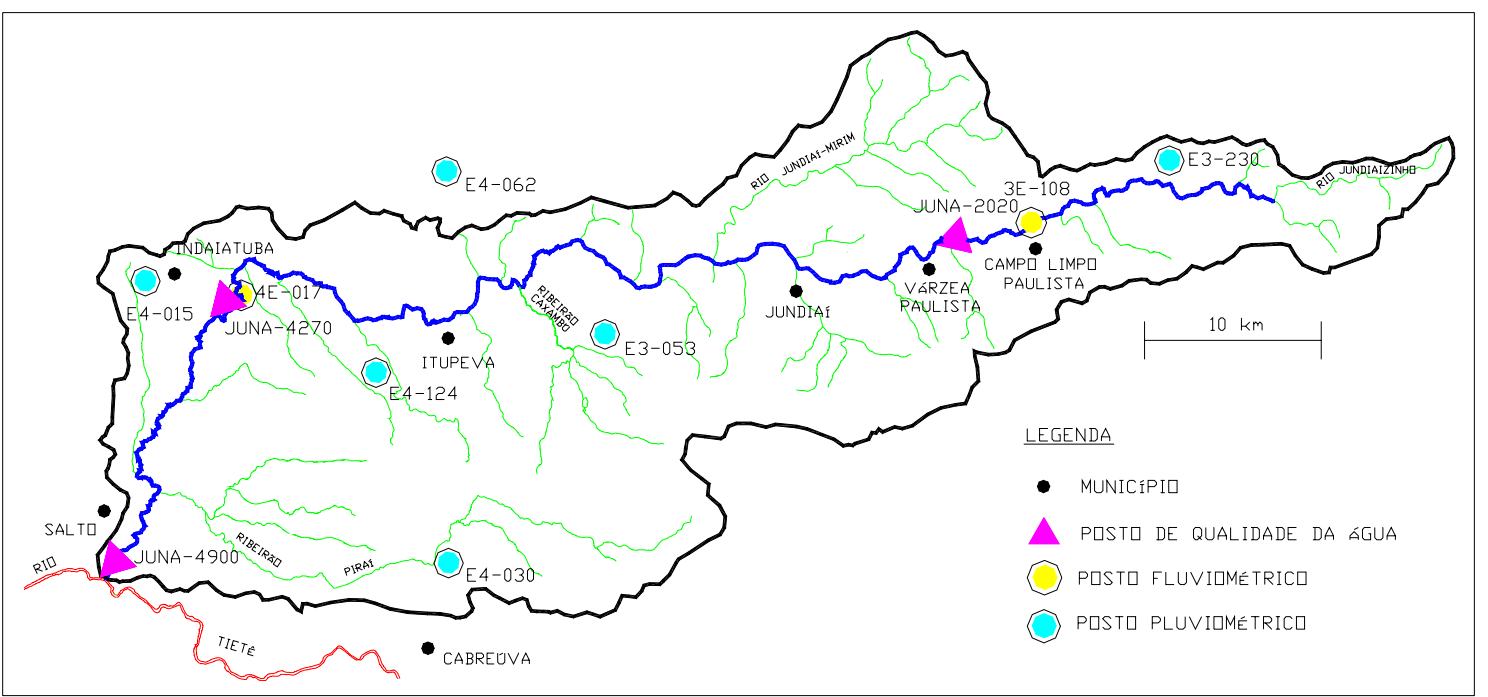

Fonte: Adaptado de CETESB - Níveis Atuais e Tendências da Qualidade das Águas Interiores do Estado de São Paulo (2003) - e IBGE (1973)

Figura 4.1 - Bacia do rio Jundiaí

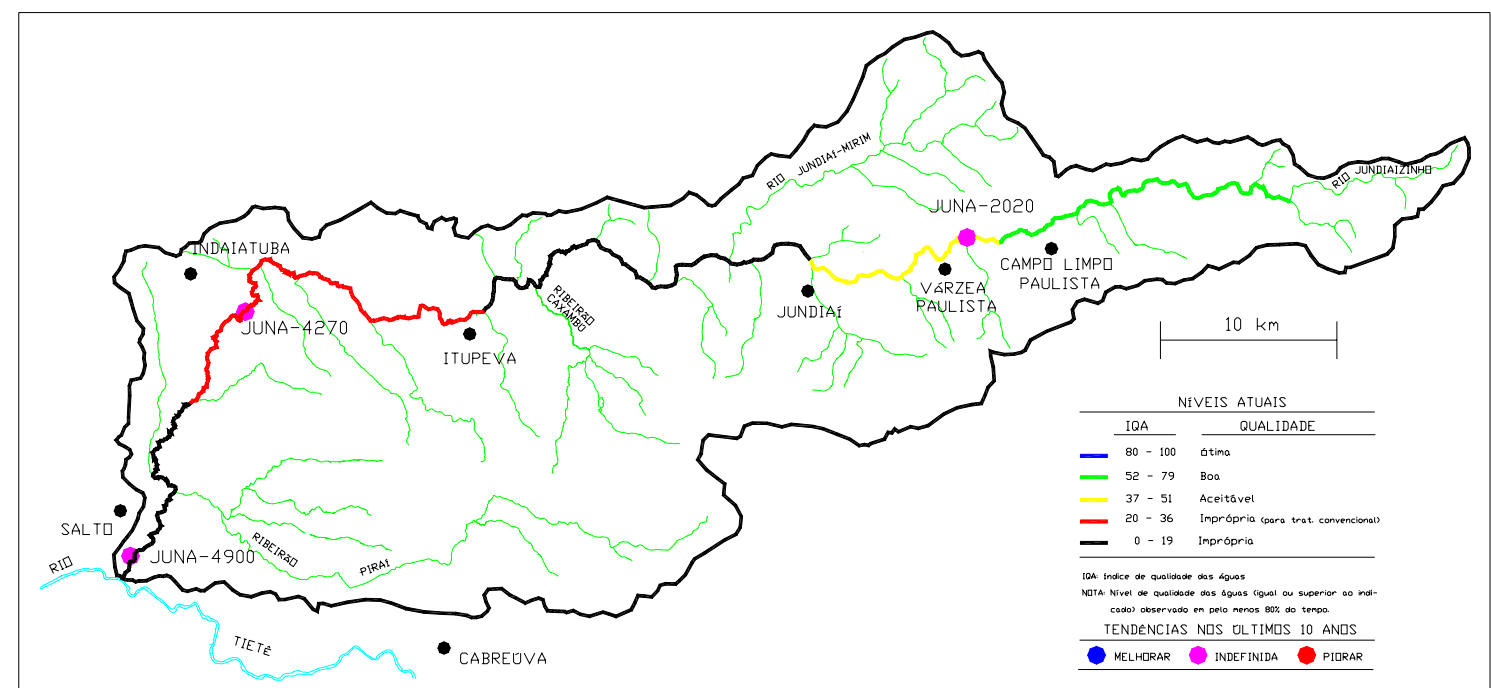

Fonte: Adaptado de CETESB - Níveis Atuais e Tendências da Qualidade das Águas Interiores do Estado de São Paulo (2003) - e IBGE (1973)

Figura 4.2 - Índice de Qualidade das Águas (IQA) do rio Jundiaí

O clima é parcialmente quente e úmido. A temperatura média anual oscila entre 18 e $20^{\circ} \mathrm{C}$, com máximas absolutas muito elevadas $\left(34\right.$ a $\left.36^{\circ} \mathrm{C}\right)$, sendo que no inverno a temperatura média das mínimas esta entre 6 e $10^{\circ} \mathrm{C}$. (CETESB, 1981) 


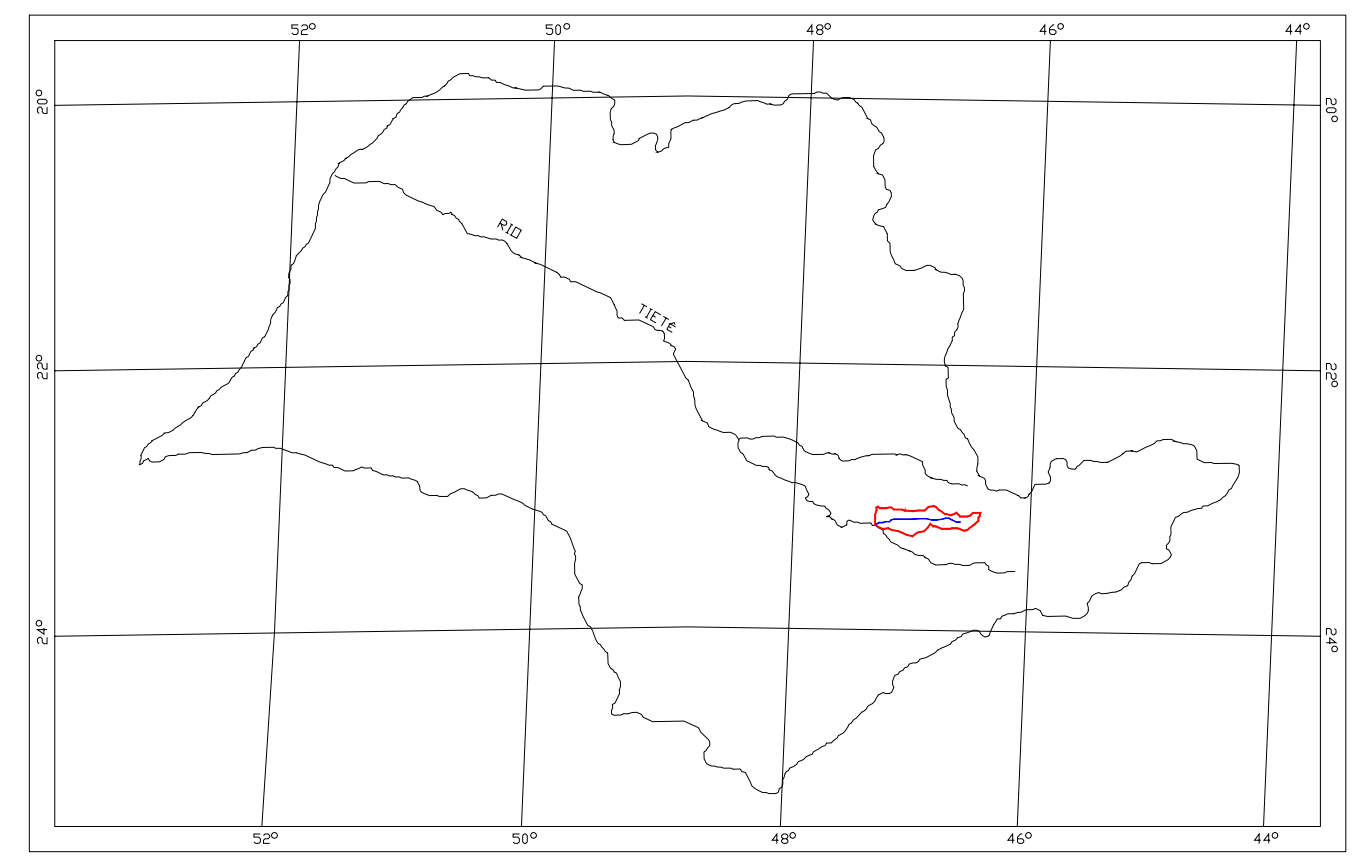

Fonte: Adaptado de IBGE (1973)

Figura 4.3 - Localização da Bacia do rio Jundiaí no Estado de São Paulo (SP)

A Bacia do rio Jundiaí tem uma população avaliada em 768.852 habitantes; somente o Município de Jundiaí abriga uma população de cerca de 322.798 habitantes. (Ver Tabela 4.1)

Tabela 4.1 - População na Bacia do rio Jundiaí

\begin{tabular}{|l|r|r|}
\hline \multicolumn{1}{|c|}{ Município } & $\begin{array}{c}\text { População } \\
\text { (número) }\end{array}$ & \multicolumn{2}{c|}{$\begin{array}{c}\text { Crescimento Anual } \\
\text { (\%) }\end{array}$} \\
\hline \hline Campo Limpo Paulista & 63.707 & 2,58 \\
\hline Várzea Paulista & 92.669 & 2,53 \\
\hline Jundiá & 322.798 & 0,27 \\
\hline Itupeva & 26.158 & 2,56 \\
\hline Cabreúva & 23.531 & 4,58 \\
\hline Indaiatuba & 146.829 & 3,89 \\
\hline Salto & 93.160 & 3,67 \\
\hline Total & 768.852 & \\
\hline
\end{tabular}

Fonte: CETESB (2001) e FOLHA DE SÃO PAULO (1997)

O rio Jundiaí nasce na região serrana de Pedra Vermelha, no município de Mairiporã, e percorre cerca de $123 \mathrm{~km}$ até a sua confluência com o rio Tietê, no reservatório da Usina de Porto Góes, no município de Salto. (CETESB, 2001) 


\subsubsection{Dados pluviométricos e fluviométricos}

A Bacia do rio Jundiaí é caracterizada por uma precipitação média mensal entre os postos de aproximadamente $120 \mathrm{~mm}$, sendo máxima junto a Serra dos Cristais, próxima à confluência com o rio Tietê (Ver Tabela 4.3 e Figura 4.4). A precipitação média anual entre os postos é de aproximadamente $1400 \mathrm{~mm}$. Embora $45 \%$ das chuvas concentramse nos meses de verão, em média não ocorre nem um mês realmente seco. (Ver Tabelas 4.2 e 4.3 , e Figura 4.4)

Tabela 4.2 - Rede de amostragem pluviométrica do DAEE na bacia em estudo

\begin{tabular}{|l|c|c|c|c|c|c|}
\hline Prefixo & Município & $\begin{array}{c}\text { Altitude } \\
(\mathbf{m})\end{array}$ & $\begin{array}{c}\text { Latitude } \\
\text { Oeste }\end{array}$ & $\begin{array}{c}\text { Longitude } \\
\text { Sul }\end{array}$ & Ano Inicial & Ano Final \\
\hline \hline E3-053 & Jundiaí & 730 & $23^{\circ} 12^{\prime}$ & $46^{\circ} 59^{\prime}$ & 1957 & 1997 \\
\hline E3-230 & Atibaia & 800 & $23^{\circ} 12^{\prime}$ & $46^{\circ} 39^{\prime}$ & 1970 & 1996 \\
\hline E4-015 & Indaiatuba & 630 & $23^{\circ} 05^{\prime}$ & $47^{\circ} 13^{\prime}$ & 1937 & 1997 \\
\hline E4-030 & Cabreúva & 750 & $23^{\circ} 16^{\prime}$ & $47^{\circ} 07^{\prime}$ & 1964 & 1997 \\
\hline E4-062 & Itupeva & 690 & $23^{\circ} 05^{\prime}$ & $47^{\circ} 03^{\prime}$ & 1963 & 1997 \\
\hline E4-124 & Indaiatuba & 700 & $23^{\circ} 10^{\prime}$ & $47^{\circ} 07^{\prime}$ & 1970 & 1997 \\
\hline \multicolumn{7}{r}{ Fonte: SECRETARIA DE RECURSOS HÍDRICOS, SANEAMENTO E OBRAS (1999) }
\end{tabular}

Tabela 4.3 - Dados pluviométricos da Bacia do rio Jundiaí

\begin{tabular}{|l|r|r|r|r|r|r|r|r|r|r|r|r|r|}
\cline { 2 - 15 } \multicolumn{1}{c|}{} & \multicolumn{10}{c|}{ Precipitação média (mm) } & anual \\
\cline { 2 - 15 } & jan & fev & mar & abr & maio & jun & jul & ago & set & out & nov & dez & \\
\hline \hline E3-053 & 222 & 199 & 137 & 77 & 86 & 63 & 47 & 35 & 79 & 110 & 131 & 198 & 1383 \\
\hline E3-230 & 210 & 188 & 169 & 79 & 88 & 62 & 52 & 45 & 93 & 133 & 150 & 234 & 1501 \\
\hline E4-015 & 209 & 165 & 130 & 70 & 67 & 48 & 44 & 35 & 71 & 106 & 131 & 203 & 1277 \\
\hline E4-030 & 239 & 198 & 139 & 83 & 82 & 68 & 53 & 39 & 88 & 127 & 157 & 235 & 1507 \\
\hline E4-062 & 243 & 189 & 166 & 87 & 76 & 56 & 48 & 37 & 89 & 116 & 154 & 227 & 1486 \\
\hline E4-124 & 226 & 178 & 137 & 79 & 81 & 62 & 51 & 40 & 80 & 123 & 142 & 220 & 1418 \\
\hline Média & 225 & 186 & 146 & 79 & 80 & 60 & 49 & 38 & 83 & 119 & 144 & 219 & 1429 \\
\hline
\end{tabular}

Fonte: SECRETARIA DE RECURSOS HÍDRICOS, SANEAMENTO E OBRAS (1999) 


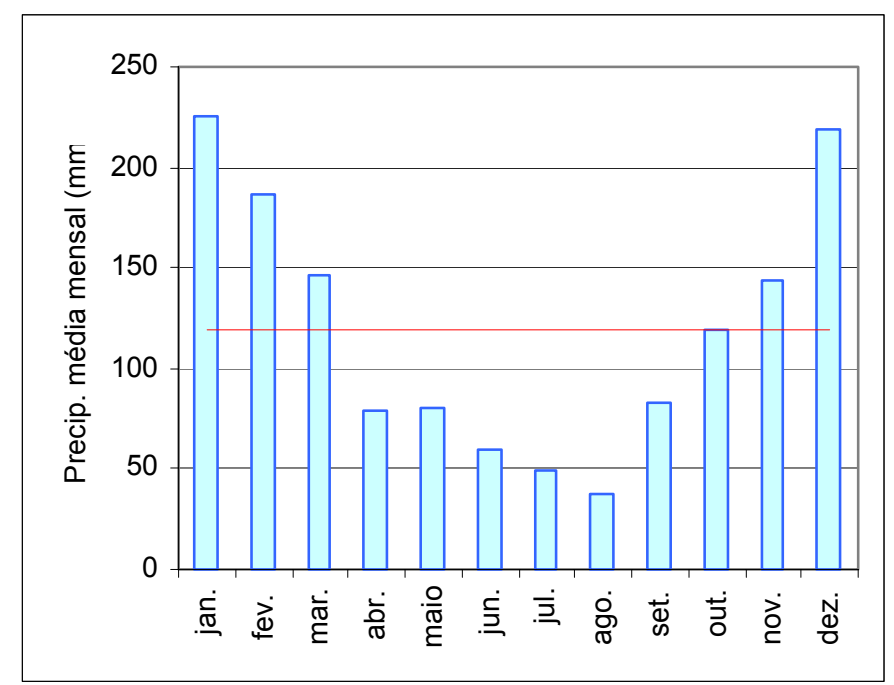

Figura 4.4 - Precipitação média mensal entre postos na bacia em estudo

O rio Jundiaí possui dois postos fluviométricos monitorados pelo Departamento de Águas e Energia Elétrica (DAEE): Posto 3E-108, localizado no Município de Campo Limpo Paulista; Posto 4E-017, localizado no Município de Indaiatuba (Ver Tabela 4.4 e Figura 4.2). A Tabela 4.5 fornece a vazão média mensal para dados de monitoramento de mais de 20 anos. As Figuras 4.5 e 4.6 mostram graficamente a vazão média mensal para os postos $3 \mathrm{E}-108$ e $4 \mathrm{E}-017$.

Tabela 4.4 - Rede de amostragem fluviométrica do DAEE na bacia em estudo

\begin{tabular}{|c|c|c|c|r|c|c|}
\hline Prefixo & Nome & $\begin{array}{c}\text { Latitude } \\
\text { (sul) }\end{array}$ & $\begin{array}{c}\text { Longitude } \\
\text { (oeste) }\end{array}$ & $\begin{array}{c}\text { Área } \\
\text { (km }^{2} \text { ) }\end{array}$ & Município & $\begin{array}{c}\text { Paralisado } \\
\text { (ano) }\end{array}$ \\
\hline \hline 3E-108 & Campo Limpo & $23^{\circ} 12^{\prime} 32^{\prime \prime}$ & $46^{\circ} 44^{\prime} 47^{\prime \prime}$ & 100 & Campo Limpo Paulista & 1996 \\
\hline 4E-017 & Itaici & $23^{\circ} 06^{\prime} 26^{\prime \prime}$ & $46^{\circ} 10^{\prime} 46^{\prime \prime}$ & 803 & Indaiatuba & 1996 \\
\hline
\end{tabular}

Fonte: SECRETARIA DE RECURSOS HÍDRICOS, SANEAMENTO E OBRAS (1999)

Tabela 4.5 - Vazão média mensal na Bacia do rio Jundiaí

\begin{tabular}{|c|c|r|r|r|r|r|r|r|r|r|r|r|}
\cline { 2 - 11 } \multicolumn{1}{c|}{} & \multicolumn{10}{c|}{ Vazão média mensal $\mathbf{~ m}^{\mathbf{3} / \mathbf{s})}$} \\
\hline Posto & jan & \multicolumn{1}{c|}{ fev } & mar & abr & maio & jun & jul & ago & set & out & nov & dez \\
\hline \hline 3E-108 & 2,11 & 2,12 & 1,92 & 1,47 & 1,35 & 1,40 & 1,23 & 1,07 & 1,17 & 1,30 & 1,29 & 1,85 \\
\hline 4E-017 & 17,09 & 15,05 & 11,78 & 10,18 & 8,70 & 9,81 & 7,60 & 6,70 & 7,71 & 8,95 & 10,06 & 14,69 \\
\hline
\end{tabular}




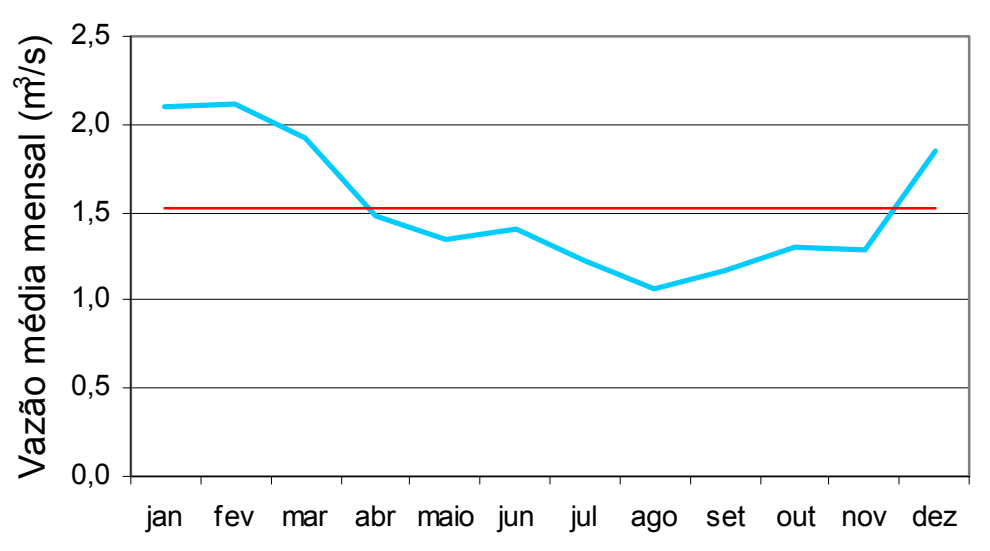

Figura 4.5 - Vazão média mensal no posto 3E-108 do rio em estudo

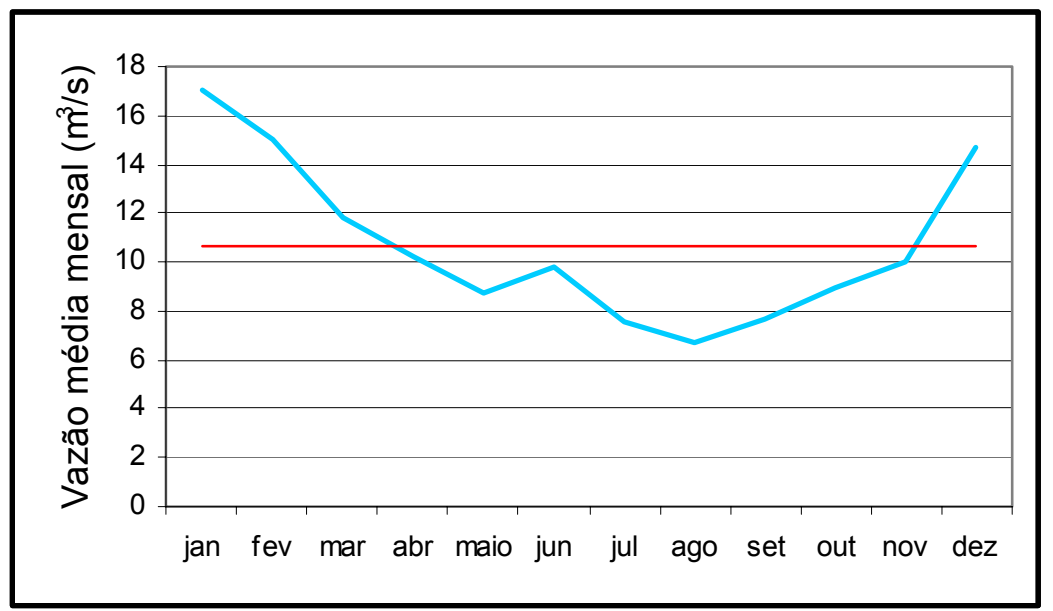

Figura 4.6 - Vazão média mensal no posto 4E-017 do rio em estudo

\subsubsection{A industrialização e as cargas poluidoras}

A industrialização na bacia do rio Jundiaí é acentuada, destacando-se o Município de Jundiaí com um parque industrial mais representativo (indústria de chapas duras de madeira, produtos alimentares, bebidas, tecelagem, metalurgia, louças e aparelhos sanitários, fósforos), sendo também considerável o parque industrial dos municípios de Campo Limpo Paulista (produção de minerais não metálicos, têxtil), Várzea Paulista (química), Indaiatuba (têxtil) e Salto (indústria de madeira e química). CETESB (2003)

O processo de degradação do rio Jundiaí ocorre, principalmente, próximo às cidades onde o processo de urbanização e industrialização foi descontrolado, como por exemplo, nas cidades de Jundiaí e Salto. 
O desenvolvimento da infra-estrutura sanitária dos municípios não conseguiu acompanhar o rápido crescimento populacional e industrial. Com isso, o lançamento de pesadas cargas orgânicas, tanto de origem doméstica como industrial (Ver Tabelas 4.6, 4.7 e 4.8) nas águas do rio Jundiaí, excedeu a sua capacidade natural de autodepuração. Isso é nitidamente percebido a jusante do Município de Jundiaí.

Tabela 4.6 - Carga orgânica industrial potencial lançada na Bacia do rio Jundiaí (ano de 1996)

\begin{tabular}{|l|r|r|r|r|r|r|r|}
\cline { 2 - 8 } \multicolumn{1}{c|}{} & \multicolumn{7}{c|}{ Carga Orgânica Industrial Potencial (kg DBO/dia) } \\
\hline \multicolumn{1}{c|}{ Lançamento } & \multicolumn{1}{c|}{ CLP } & \multicolumn{1}{c|}{ VP } & \multicolumn{1}{c|}{ Jundiaí } & Itupeva & Cabreuva & Indaiatuba & \multicolumn{1}{c|}{ Salto } \\
\hline \hline Diretamente no Rio Jundiaí & 0,0 & 681,4 & 872,7 & 1697,0 & 0,0 & 341,0 & 15759,0 \\
\hline Diretamente nos afluentes & 0,0 & 360,0 & 2192,7 & 208,2 & 1436,0 & 110,9 & 0,0 \\
\hline Diretamente na rede públ. de esg. & 235,0 & 237,2 & 40792,9 & 0,0 & 0,0 & 416,3 & 0,0 \\
\hline Total & 235,0 & 1278,6 & 43858,3 & 1905,2 & 1436,0 & 868,2 & 15759,0 \\
\hline
\end{tabular}

Carga Orgânica Potencial - Carga potencial gerada; CLP - Campo Limpo Paulista; VP - Várzea Paulista

Fonte: Adaptado de CETESB (1996) - Dados não publicados.

Tabela 4.7 - Carga orgânica industrial remanescente gerada na Bacia do rio Jundiaí (ano de 1996)

\begin{tabular}{|l|r|r|r|r|r|r|r|}
\cline { 2 - 8 } \multicolumn{1}{c|}{} & \multicolumn{7}{c|}{ Carga Orgânica Industrial Remanescente (kg DBO/dia) } \\
\hline \multicolumn{1}{c|}{ Lançamento } & \multicolumn{1}{c|}{ CLP } & \multicolumn{1}{c|}{ VP } & Jundiaí & Itupeva & Cabreuva & Indaiatuba & Salto \\
\hline \hline Diretamente no Rio Jundiaí & 0,0 & 681,4 & 166,5 & 742,2 & 0,0 & 263,0 & 4239,0 \\
\hline Diretamente nos afluentes & 0,0 & 39,2 & 378,3 & 12,4 & 65,0 & 22,2 & 0,0 \\
\hline Diretamente na rede públ. de esg. & 235,0 & 237,2 & 24559,0 & 0,0 & 0,0 & 130,6 & 0,0 \\
\hline Total & 235,0 & 957,8 & 25103,8 & 754,6 & 65,0 & 415,8 & 4239,0 \\
\hline
\end{tabular}

Carga Remanescente - Carga efetivamente lançada; CLP - Campo Limpo Paulista; VP - Várzea Paulista Fonte: Adaptado de Cetesb (1996) - Dados não publicados

Tabela 4.8 - Carga orgânica doméstica gerada na Bacia do rio Jundiaí (ano de 1996)

\begin{tabular}{|l|r|r|r|r|r|r|r|}
\cline { 2 - 8 } \multicolumn{1}{c|}{} & \multicolumn{6}{c|}{ Carga Orgânica Doméstica (kg DBO/dia) } \\
\hline \multicolumn{1}{c|}{ Lançamento } & Campo Limpo Pta. & Várzea Pta. & Jundiaí & Itupeva & Cabreuva & Indaiatuba & Salto \\
\hline \hline Potencial & 2541,7 & 3795,3 & 14251,3 & 1000,6 & 1143,6 & 5936,9 & 4210,3 \\
\hline Remanescente & 2541,7 & 3795,3 & 14251,3 & 1000,6 & 857,7 & 5462,0 & 631,5 \\
\hline
\end{tabular}

Fonte: Adaptado de CETESB (1996) - Dados não publicados. 
A partir de setembro de 1998, a ETE de Jundiaí entrou em operação e, atualmente, está tratando cerca de $54.000 \mathrm{~m}^{3} /$ dia de esgotos domésticos e industriais, o que representa uma $\mathrm{DBO}_{5,20}$ bruta de $514 \mathrm{mg} / \mathrm{L}$ e $\mathrm{DBO}_{5,20}$ tratada de $73 \mathrm{mg} / \mathrm{L}$. A eficiência da ETE em termos de remoção de $\mathrm{DBO}_{5,20}$ atinge $85 \%$. Esses dados mostram que a cidade de Jundiaí, muito embora não esteja totalmente com seus esgotos enviados a ETE, trata uma carga orgânica de $16,18 \mathrm{tDBO}_{5,20} /$ dia que, após o tratamento, tem um residual de cerca de 4,79 tDBO $_{5,20} /$ dia, lançado no rio Jundiaí. CETESB (2003)

A carga orgânica poluidora das águas da bacia provém, principalmente, dos esgotos domésticos e industriais, sendo este último predominante apenas nos Municípios de Jundiaí, com aproximadamente $64 \%$ da carga gerada, e de Salto, com aproximadamente $88 \%$ da carga gerada, ver tabelas 4.7 e 4.8. A Figura 4.7 representa a carga orgânica gerada e lançada diretamente na rede de esgoto dos respectivos municípios.

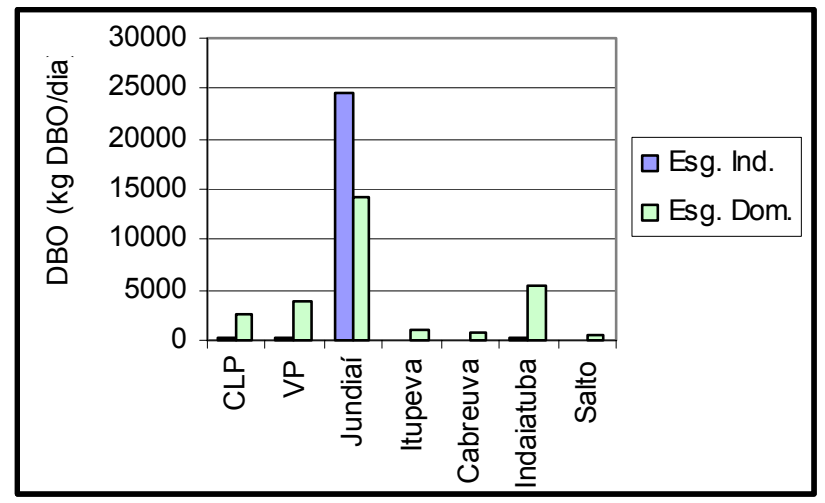

Figura 4.7 - Carga orgânica doméstica e industrial gerada e lançada na rede de esgoto

\subsubsection{Qualidade das águas do rio Jundiaí}

O estudo da qualidade das águas do rio Jundiaí foi realizado com dados de monitoramento de qualidade da água da rede de monitoramento da CETESB, de 1978 a 2003, para os postos JUNA-2020 e JUNA-4270, já o posto JUNA-4900 teve seu inicio de operação em agosto de 1993. As Figuras 4.8 a 4.13, apresentam os resultados observados.

No posto de monitoramento JUNA-2020, localizado no município de Campo Limpo Paulista, nas proximidades da cabeceira, a concentração média de OD dos anos de 1978 a 1997 foi de 7,5 mg/L. A partir do ano de 1997 ocorre um declínio na concentração de 
OD que chegou no ano de 2003 com uma concentração média de 5,5 mg/L. Já para a DBO a concentração oscilou em torno de $2 \mathrm{mg} / \mathrm{L}$ de 1978 a 1997, com um aumento gradual a partir de 1997, chegando em 2003 com uma concentração média de aproximadamente $8 \mathrm{mg} / \mathrm{L}$.

Para o posto de monitoramento JUNA-4270, localizado no município de Indaiatuba, observou-se uma concentração média de OD dos anos de 1978 a 1997 de 4 mg/L, associada a uma concentração média de DBO de $15 \mathrm{mg} / \mathrm{L}$. Estas concentrações apresentam grandes oscilações, como pode ser observado nos gráficos 4.10 e 4.11. A partir do ano de 1997, ocorreu uma tendência de declínio na concentração de OD, que chegou em 2003 com uma concentração média inferior a $3 \mathrm{mg} / \mathrm{L}$, associada a uma concentração de DBO de $25 \mathrm{mg} / \mathrm{L}$.

A melhor qualidade das águas no posto de Campo Limpo Paulista (JUNA-2020) é devido à baixa concentração populacional e industrial a montante do mesmo, associada a lançamentos de carga de DBO de pequena magnitude.

O declínio na qualidade das águas, no posto JUNA-4270, com relação ao posto de monitoramento de montante (JUNA-2020), deve-se ao lançamento de pesadas cargas de DBO a montante do mesmo. A qualidade das águas neste ponto só não é mais crítica devido à capacidade de autodepuração do rio Jundiaí. Isso pode ser observado através do lançamento provido da rede pública de esgoto do município de Jundiaí, em que no trecho a jusante do mesmo encontra-se em condições de anaerobiose.

O trecho crítico de poluição das águas do rio Jundiaí está localizado a jusante da cidade de Jundiaí, entre os afluentes Jundiaí-Mirim e Ribeirão Caxambu. Neste trecho ocorre o lançamento do efluente proveniente da rede pública de esgoto do município de Jundiaí.

Para o posto JUNA-4900, localizado no município de Salto, na proximidade da foz do rio Jundiaí com o rio Tietê, a concentração de OD chegou no ano de 1997 com uma concentração média de aproximadamente $2 \mathrm{mg} / \mathrm{L}$, associada a uma concentração de DBO de $35 \mathrm{mg} / \mathrm{L}$. A partir do ano de 1997 também se verificou um declínio ainda maior na concentração de OD e uma ascensão na concentração de DBO. Em 2003, a 
concentração média de OD chegou a ser inferior a $0,5 \mathrm{mg} / \mathrm{L}$, associada a uma DBO média superior a $70 \mathrm{mg} / \mathrm{L}$.

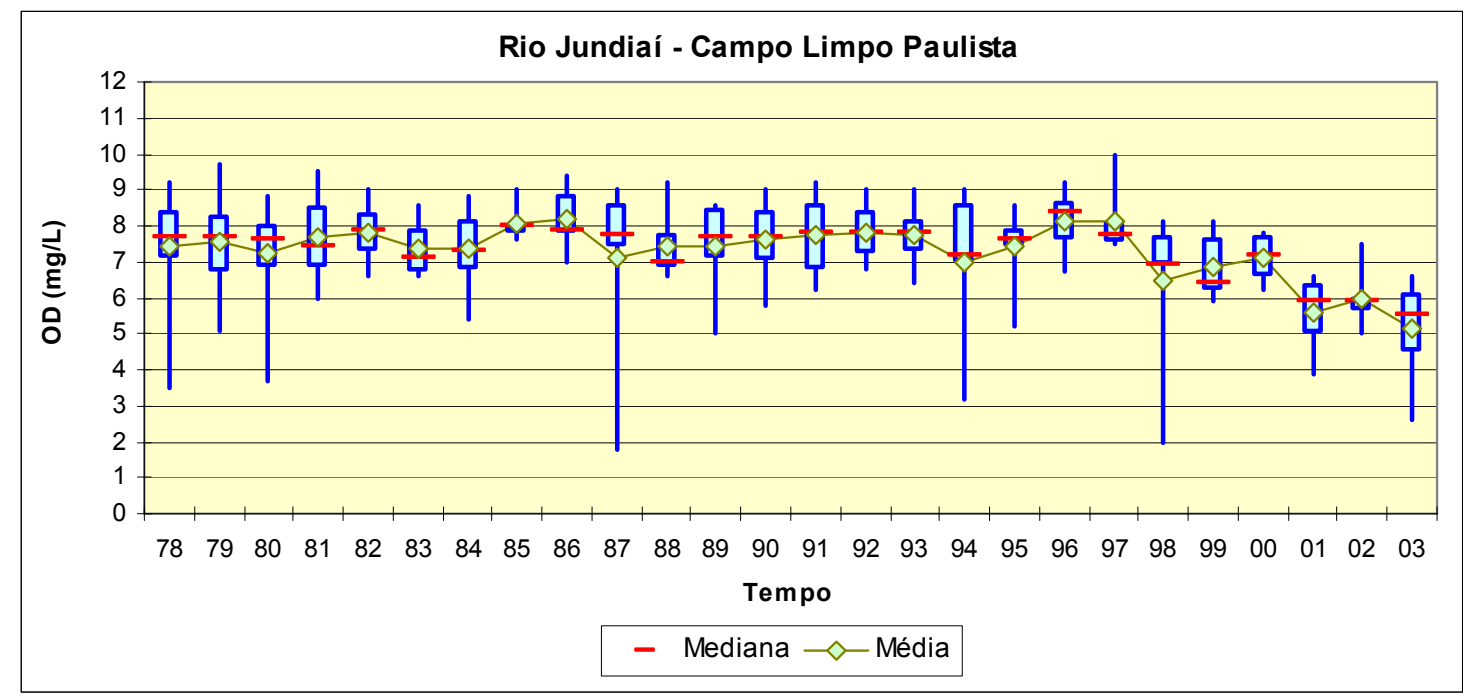

Figura 4.8 - Concentração média anual de OD no posto JUNA-2020

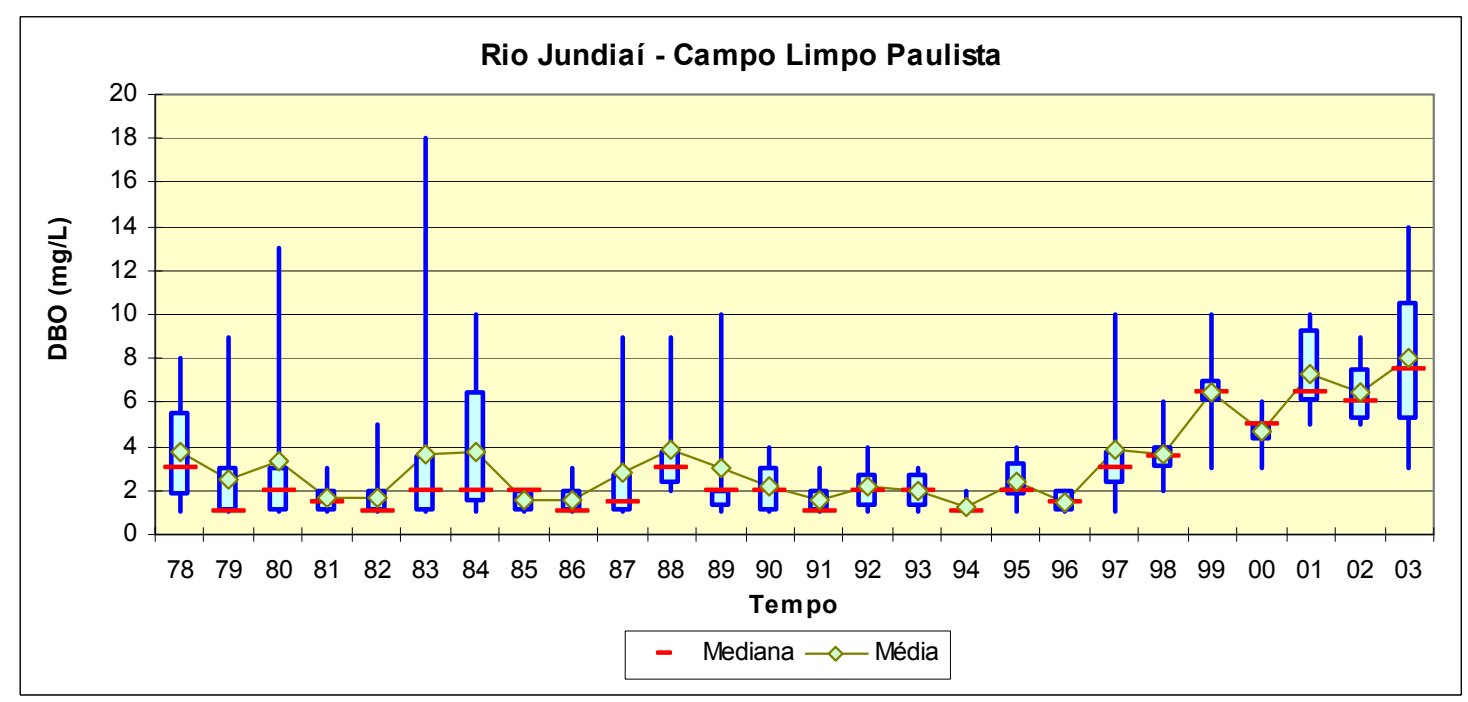

Figura 4.9 - Concentração média anual de DBO no posto JUNA-2020 


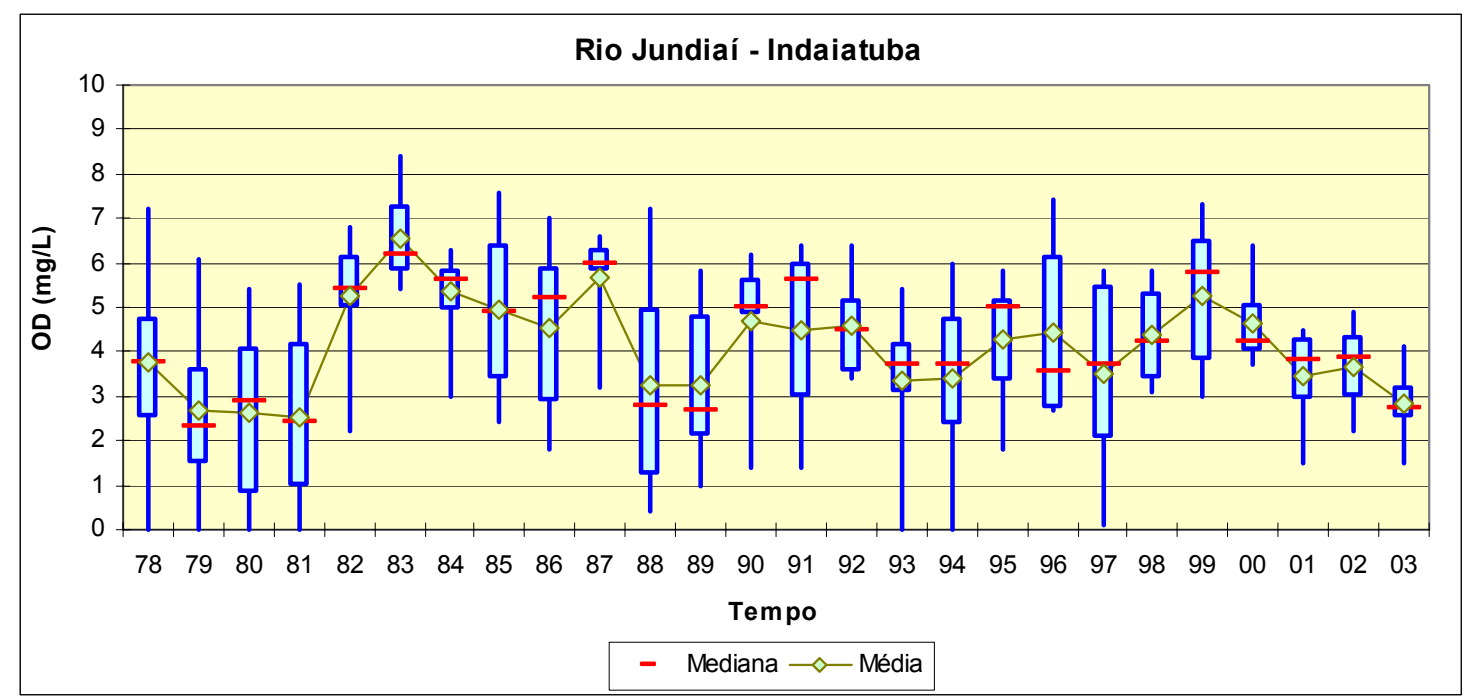

Figura 4.10 - Concentração média anual de OD no posto JUNA-4270

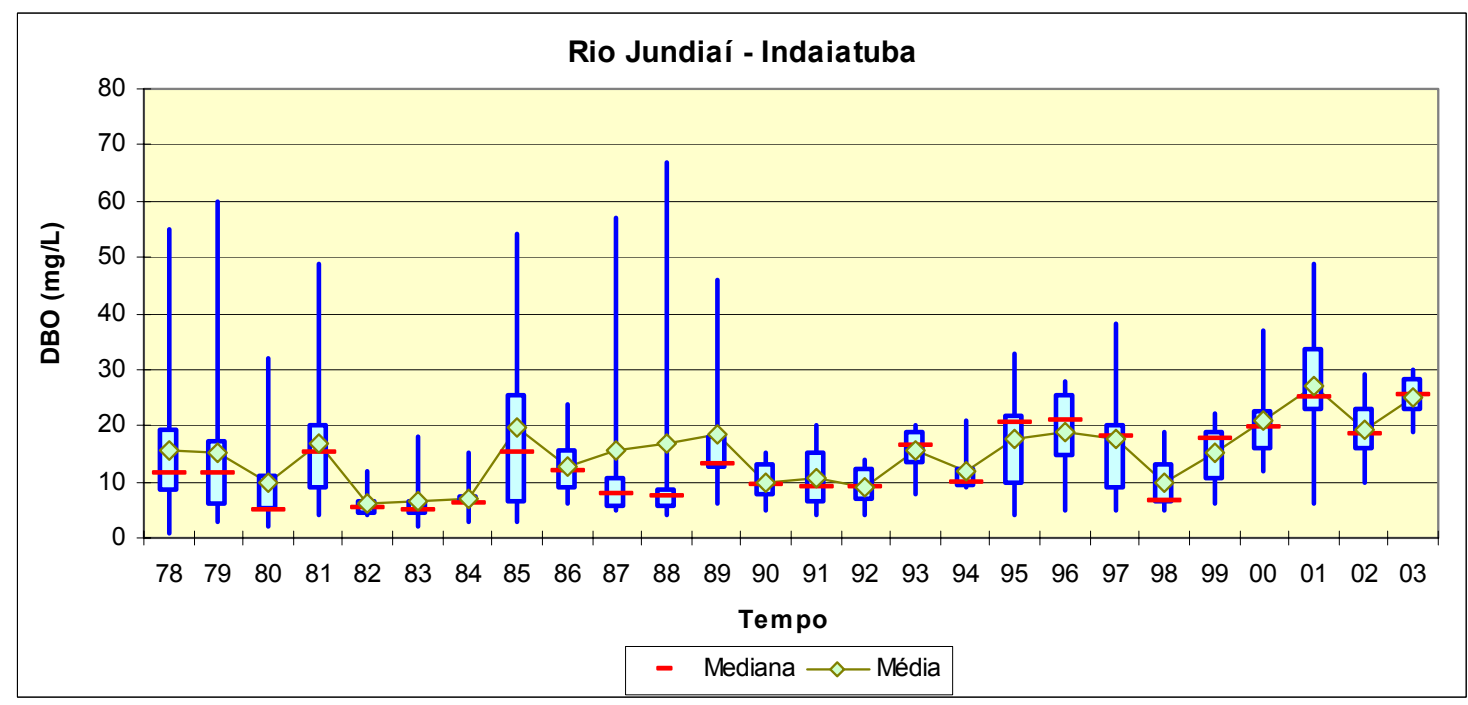

Figura 4.11 - Concentração média anual de DBO no posto JUNA-4270 


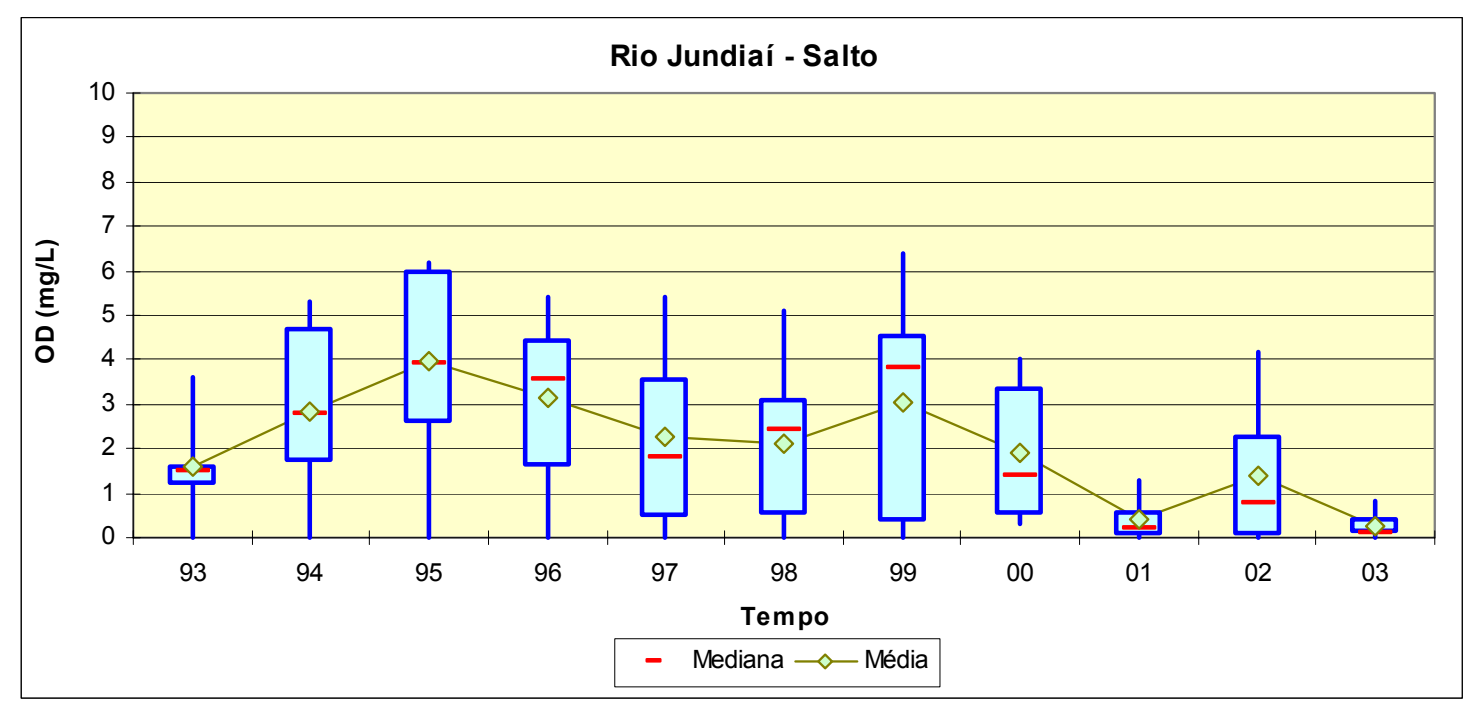

Figura 4.12 - Concentração média anual de OD no posto JUNA-4900

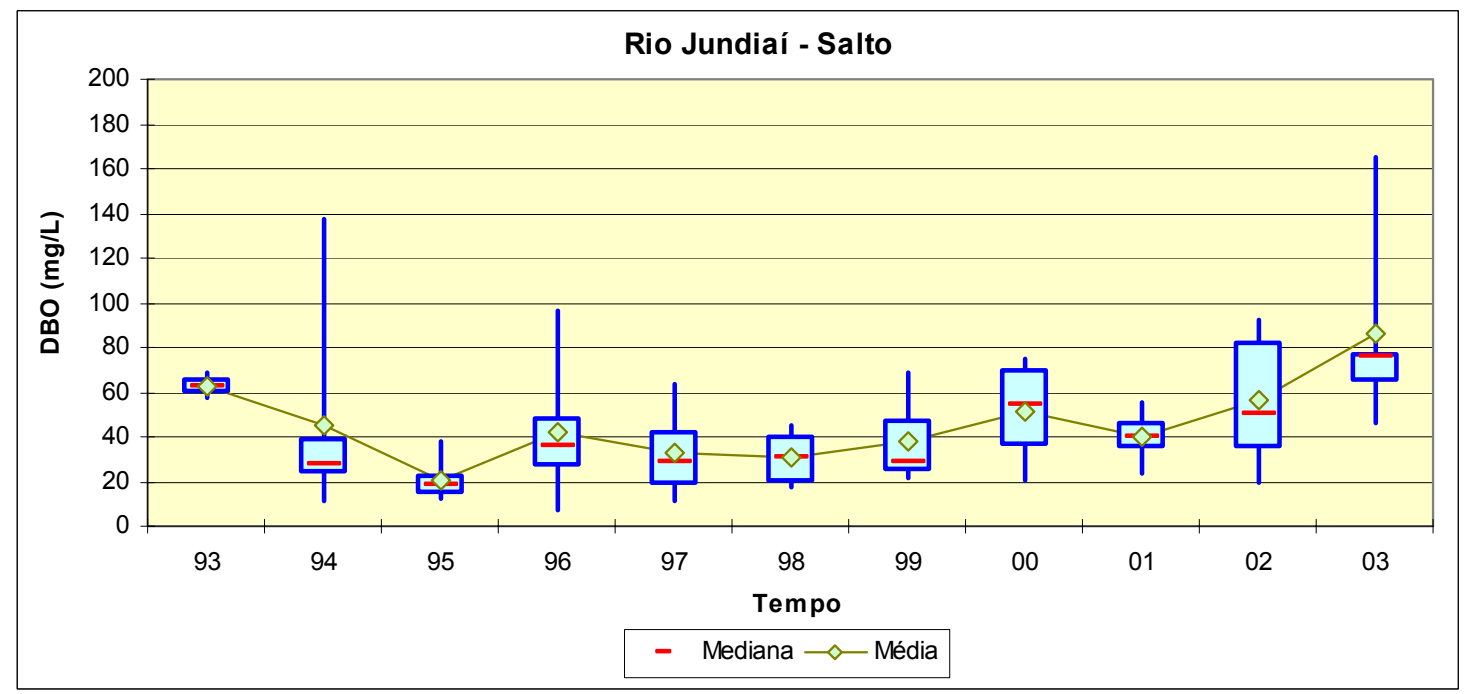

Figura 4.13 - Concentração média anual de DBO no posto JUNA-4900 
Nos postos de qualidade das águas monitorados, a constatação do declínio da concentração de OD a partir de 1997, associada a um aumento da concentração de DBO, pode estar relacionada a um maior adensamento populacional e industrial no período, assim como a um menor índice pluviométrico observado no período de 1998 a 2003 dentro da série histórica de dados observados. O menor índice pluviométrico no período de 1998 a 2003 pode ser constatado através da Figura 4.14 que apresenta a série histórica de dados pluviométricos na Região do Alto Tietê.

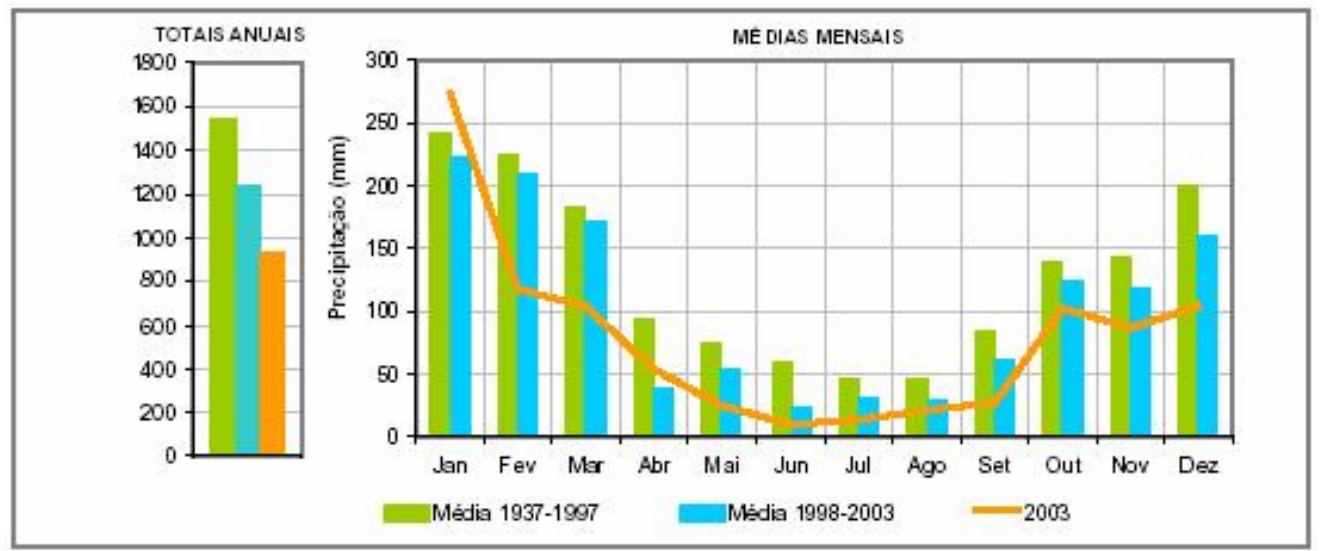

Fonte: CETESB (2003)

Figura 4.14 - Dados pluviométricos na Bacia do Alto Tietê

Para ilustrar numericamente a estiagem desses últimos anos, pode-se dizer que, considerando a média precipitada no período de 1998-2003 de $1241 \mathrm{~mm}$ e a média histórica de $1508 \mathrm{~mm}$, iniciou-se 2004 com um débito anual de chuvas de $267 \mathrm{~mm}$, o que totaliza um déficit de $1600 \mathrm{~mm}$ no período de 1998 a 2003. CETESB (2003)

A partir de setembro de 1998, a ETE de Jundiaí entrou em operação, removendo hoje cerca de $85 \%$ da carga de DBO. A redução da carga de DBO pela ETE não é observada na série histórica do ponto de monitoramento de jusante (JUNA-4270). Isto pode estar associado à alta carga de DBO remanescente da ETE, quando relacionada à capacidade assimilativa do rio no trecho de $22 \mathrm{~km}$ entre o lançamento da ETE e o posto de monitoramento JUNA-4270, assim como a piora na qualidade das águas, associada ao menor índice pluviométrico observado no período de 1998 a 2003. 


\subsubsection{Enquadramento}

As águas superficiais da bacia do rio Jundiaí, de acordo com o decreto $\mathrm{n}^{\circ} 10.755 / 77$, estão enquadradas da cabeceira do rio ao ponto de monitoramento JUNA-2020 na Classe 2 ao longo de uma extensão de aproximadamente $26 \mathrm{~km}$. Já do ponto de monitoramento JUNA-2020 à foz do rio Jundiaí, o rio está enquadrado na Classe 4 ao logo de uma extensão de aproximadamente $97 \mathrm{~km}$.

\subsection{Dados de entrada do modelo QUAL2E e calibração}

As variáveis de estado selecionadas para simulação foram OD e DBO. E os coeficientes de ajustes selecionados para calibração foram os parâmetros de desoxigenação $\left(K_{1}\right)$, reaeração $\left(\mathrm{K}_{2}\right)$, e sedimentação $\left(\mathrm{K}_{3}\right)$.

\subsubsection{Entrada de dados}

\section{a) Segmentação do sistema}

O sistema fluvial foi dividido em trechos com características hidráulicas semelhantes, e estes trechos foram subdivididos em elementos de comprimento de $1 \mathrm{~km}$ cada. Os critérios adotados para a divisão do rio em trechos foram:

- Dados obtidos através do mapa topográfico da bacia, como curvas de nível, declividade e visualização espacial da disposição do percurso do rio.

- Adequação às limitações do modelo.

Este processo resultou na divisão do rio Jundiaí, de $123 \mathrm{~km}$ de comprimento, em 15 trechos. (Ver Figura 4.15) 

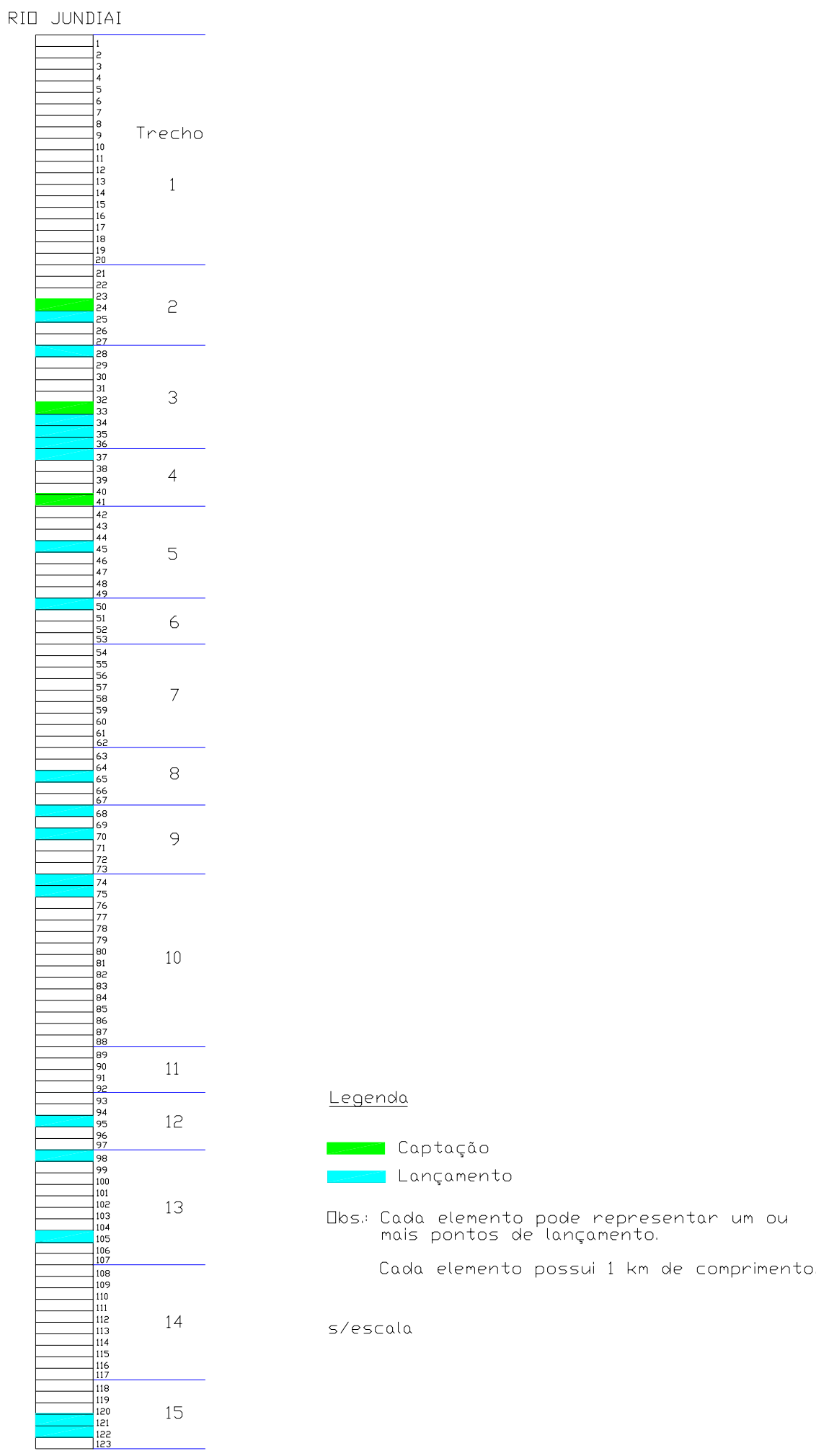

s/escala

Fonte: AUTORA

Figura 4.15 - Diagrama unifilar e alocação de cargas para a calibração do modelo QUAL2E 


\section{b) Dados hidráulicos}

Neste trabalho foram utilizados os coeficientes de descargas para a determinação dos dados hidráulicos, sendo as constantes empíricas (dados de entrada) obtidas através de equações de potência (Equações 3.15.a, 3.15.b e 3.15.c, na pág. 51).

Devido à existência de apenas dois postos fluviométricos de monitoramento na bacia, as constantes empíricas obtidas para o posto 3E-108, localizado no Município de Campo Limpo Paulista, foram utilizadas da cabeceira do rio ao ponto de entrada do afluente Jundiaí-Mirim, compreendendo um trecho de aproximadamente $50 \mathrm{~km}$; assim como as constantes empíricas obtidas através do posto 4E-017, localizado no Município de Indaiatuba, foram utilizadas do trecho de jusante do afluente Jundiaí-Mirim até a foz do rio, compreendendo um trecho de aproximadamente $73 \mathrm{~km}$. Os valores de vazão por trecho foram obtidos por interpolação entre os postos.

As vazões dos afluentes não inclusos no protótipo do rio Jundiaí foram acrescentadas no corpo do rio, em função da área de drenagem. Assim como, as vazões de captação não alocadas foram retiradas do sistema.

\section{c) Dados de cargas}

Para maior simplicidade na simulação do modelo QUAL2E, foi desprezada a capacidade de autodepuração dos afluentes. As cargas orgânicas lançadas nos afluentes nas proximidades da margem do rio foram consideradas como sendo lançadas diretamente no rio Jundiaí.

As cargas distribuídas, associadas aos respectivos incrementos de vazões proporcionados pela respectiva área de drenagem, foram consideradas com uma concentração de $1 \mathrm{mg} / \mathrm{L}$ de DBO ao longo de todo o sistema.

A Tabela 4.9 fornece os pontos de lançamento de cargas considerados para a entrada de dados no protótipo. Para simplificação, um ponto de lançamento pode representar uma somatória de cargas localizadas próximas, para as quais efetuou-se o respectivo balanço de massa. 
Tabela 4.9 - Carga lançada no rio Jundiaí para calibração do modelo QUAL2E (ano de 1996)

\begin{tabular}{|c|c|c|c|c|c|c|c|c|c|c|c|c|c|}
\hline \multirow[t]{3}{*}{$\mathrm{No}$} & \multirow[t]{3}{*}{ Lançamento } & \multirow[t]{3}{*}{ Município } & \multicolumn{3}{|c|}{ Localização } & \multirow{3}{*}{$\begin{array}{l}\text { Popul. } \\
\text { (hab.) }\end{array}$} & \multirow{2}{*}{\multicolumn{2}{|c|}{$\begin{array}{c}\text { Carga de DBO } \\
\text { (kg/dia) }\end{array}$}} & \multicolumn{2}{|c|}{ Vazão } & \multirow{2}{*}{\multicolumn{3}{|c|}{$\begin{array}{l}\text { DBO } \\
\text { (mg/L) }\end{array}$}} \\
\hline & & & \multirow[t]{2}{*}{ km } & \multirow[t]{2}{*}{ Trecho } & \multirow[t]{2}{*}{ Elem. } & & & & \multirow[t]{2}{*}{$\left(\mathrm{m}^{3} / \mathrm{dia}\right)$} & \multirow[t]{2}{*}{$\left(\mathrm{m}^{3} / \mathrm{s}\right)$} & & & \\
\hline & & & & & & & PT & RM & & & PT & RM & $(\%)$ \\
\hline \multirow{3}{*}{\begin{tabular}{l|l}
1 & \\
& \\
\end{tabular}} & Jorma Ind. De Comp. Eletr. & CLP & 25 & 2 & 25 & & 38,7 & 38,7 & 1000,0 & 0,0116 & 39 & 39 & 0,0 \\
\hline & Ind. Com. Tecido Yale Ltda. & & & & & & 235,0 & 235,0 & 685,2 & 0,0079 & 343 & 343 & 0,0 \\
\hline & Balanço de Massa & & & & & & 273,7 & 273,7 & 1685,2 & 0,0195 & 162 & 162 & \\
\hline 2 & Esg. Dom. Campo Limpo Pta & CLP & 28 & 3 & 28 & 52299 & 2541,7 & 2541,7 & 10459,8 & 0,1211 & 243 & 243 & 0,0 \\
\hline 3 & Elekeiroz S/A & VP & 34 & 3 & 34 & & 270,4 & 270,4 & 2393,3 & 0,0277 & 113 & 113 & 0,0 \\
\hline 4 & Ad'ouro Alim. e Com. Ltda & VP & 35 & 3 & 35 & & 360,0 & 39,2 & 392,3 & 0,0045 & 918 & 100 & 89,1 \\
\hline 5 & Advance Ind. Textil Ltda & VP & 36 & 3 & 36 & & 411,0 & 411,0 & 960,0 & 0,0111 & 428 & 428 & 0,0 \\
\hline \multirow{3}{*}{6} & Esg. Dom. de Vázea Pta. & VP & 37 & 4 & 37 & 78093 & 3795,3 & 3795,3 & 15618,6 & 0,1808 & 243 & 243 & 0,0 \\
\hline & Tintura Universo Ltda & & & & & & 237,3 & 237,3 & \begin{tabular}{|l|}
927,1 \\
\end{tabular} & 0,0107 & 256 & 256 & 0,0 \\
\hline & Balanço de Massa & & & & & & 4032,6 & 4032,6 & 16545,7 & 0,1915 & 244 & 244 & 0,0 \\
\hline 7 & Fiação Tec. Kanebo S/A & Jundiaí & 45 & 5 & 45 & & 826,1 & 109,9 & 685,0 & 0,0079 & 1206 & 160 & 86,7 \\
\hline 8 & Flocotécnica Ind. e Com. Ltd & Jundiaí & 50 & 6 & 50 & & 46,6 & 46,6 & 96,4 & 0,0011 & 483 & 483 & 0,0 \\
\hline \multirow{3}{*}{9} & Esg. Dom. de Jundiaí & Jundiaí & 65 & 8 & 65 & 293237 & 14251,3 & 14251,3 & 58647,4 & 0,6788 & 243 & 243 & 0,0 \\
\hline & Bal. de mas. efl. de 27 ind. & & & & & & 26539,4 & 12424,3 & 12863,3 & 0,1489 & 3171 & 2074 & 34,6 \\
\hline & Balaço de Massa & & & & & & 40790,7 & 26675,6 & 71510,7 & 0,8277 & 770 & 573 & 25,5 \\
\hline 10 & Ind. Papel Gordini Braun & Jundiaí & 68 & 9 & 68 & & 1952,3 & 378,0 & 4272,0 & 0,0494 & 457 & 88 & 80,6 \\
\hline 11 & Akzo Nobel Ltda & Itupeva & 70 & 9 & 70 & & 1007,4 & 742,2 & 447,1 & 0,0052 & 2253 & 1660 & 26,3 \\
\hline 12 & BBC Ind. e Com. Ltda & Itupeva & 74 & 10 & 74 & & 200,0 & 10,0 & 30,0 & 0,0003 & 6667 & 333 & 95,0 \\
\hline 13 & Esg. Dom. de Itupeva & Itupeva & 75 & 10 & 75 & 20589 & 1000,6 & 1000,6 & 4117,8 & 0,0477 & 243 & 243 & 0,0 \\
\hline 14 & Lins. Ind. E Com. Ltda & Indaiatuba & 95 & 12 & 95 & & 253,0 & 253,0 & 48,0 & 0,0006 & 5271 & 5271 & 0,0 \\
\hline 15 & Ind. Gessy Lever Ltda & Indaiatuba & 98 & 13 & 98 & & 88,0 & 10,0 & 58,0 & 0,0007 & 1517 & 172 & 88,6 \\
\hline 16 & Esg. Dom. de Indaiatuba & Indaiatuba & 105 & 13 & 105 & 122159 & 5936,9 & 5462,0 & 24431,8 & 0,2828 & 243 & 224 & 8,0 \\
\hline & Indaiatuba Textil S/A & & & & & & 112,5 & 100,3 & 329,0 & 0,0038 & 342 & 305 & 10,8 \\
\hline & Crovel Com. Ref. de Óleos & & & & & & 303,8 & 30,3 & 11,0 & 0,0001 & 27618 & 2755 & 90,0 \\
\hline & Fintros Mann Ltda & & & & & & 110,9 & 22,2 & 207,3 & 0,0024 & 535 & 107 & 80,0 \\
\hline & Balanço de Massa & & & & & & 6464,1 & 5614,8 & 24979,1 & 0,2891 & 259 & 225 & 13,1 \\
\hline 17 & Esg. Dom. de Salto & Salto & 122 & 15 & 121 & 86631 & 4210,3 & 631,5 & 17326,2 & 0,2005 & 243 & 36 & 85,0 \\
\hline 18 & Eucatex Madeira Ltda & Salto & 123 & 15 & 122 & & 14400,0 & 2880,0 & 7200,0 & 0,0833 & 2000 & 400 & 80,0 \\
\hline & Eucatex Química Ltda & & & & & & 1359,0 & 1359,0 & 226,3 & 0,0026 & 6005 & 6005 & 0,0 \\
\hline & Balanço de Massa & & & & & & 15759,0 & 4239,0 & 7426,3 & 0,0860 & 2122 & 571 & 73,1 \\
\hline
\end{tabular}

CLP - Campo Limpo Paulista; VP - Várzea Paulista; PT - Potencial (Carga ou concentração potencial

gerada); RM - Remanescente (Carga ou concentração efetivamente lançada)

Fonte: Adaptado de CETESB (1996) - Dados não publicados 


\subsubsection{Calibração}

O processo de calibração consiste, após entrada dos dados hidráulicos e qualitativos, no ajuste dos parâmetros considerados (parâmetro de reaeração - $K_{2}$, parâmetro de desoxigenação $-\mathrm{K}_{1}$ - e parâmetro de sedimentação $-\mathrm{K}_{3}$ ) aos valores calculados e observados das variáveis de estado selecionadas (OD e DBO).

No presente trabalho, a calibração do modelo QUAL2E para a bacia do rio Jundiaí foi feita em quatro períodos, sendo estes: $1^{\circ}$ período, referente aos meses de janeiro, fevereiro e março; $2^{\circ}$ período, referente aos meses de abril, maio e junho; $3^{\circ}$ período, referente aos meses de julho, agosto e setembro; $4^{\circ}$ período, referente aos meses de outubro, novembro e dezembro. Os meses do ano foram agrupados devido à semelhança de vazões médias mensais entre os mesmos, resultando em vazões médias trimestrais. (Ver Tabela 4.10)

Neste sentido, cada parâmetro foi ajustado para cada período.

Tabela 4.10 - Vazão média trimestral considerada para calibração do modelo QUAL2E

\begin{tabular}{|c|r|r|r|r|}
\cline { 2 - 5 } \multicolumn{1}{c|}{} & \multicolumn{4}{c|}{ Vazão média trimestral $\left(\mathrm{m}^{3} / \mathrm{s}\right)$} \\
\hline Posto & jan/fev/mar & abr/maio/jun & jul/ago/set & out/nov/dez \\
\hline \hline 3E-108 & 2,05 & 1,41 & 1,16 & 1,48 \\
\hline 4E-017 & 14,64 & 9,56 & 7,34 & 11,24 \\
\hline
\end{tabular}

Fonte: Adaptado de SECRETARIA DE RECURSOS HÍDRICOS, SANEAMENTO E OBRAS (1999)

A comparação entre os valores observados e calculados foi realizada através dos dados de monitoramento de qualidade das águas dos postos JUNA-2020 e JUNA-4270 para as variáveis $\mathrm{OD}$ e $\mathrm{DBO}$, correlacionando estes com a vazão média trimestral, referente a cada posto de monitoramento e a cada período selecionado, dentro de toda a série de monitoramento. O posto de monitoramento JUNA-4900 não foi considerado no processo de calibração do modelo devido: a não existência de um posto de monitoramento fluviométrico nas proximidades do posto de qualidade; o posto de monitoramento JUNA-4900 iniciou sua operação em 1993, a série histórica utilizada para calibração do modelo foi de 1978 a 1995. 
O modelo foi dado por calibrado para cada período, quando os valores calculados estavam compreendidos entre os valores $50 \%$ mais freqüentes da série observada.

Os postos fluviométricos da bacia foram desativados a partir de 1996, logo, a calibração do modelo utilizou a série histórica de dados de qualidade e quantidade de 1978 a 1995 , porque, no processo de calibração, o dado de vazão foi diretamente relacionado ao dado de qualidade, assim, foi utilizado o cenário de cargas de lançamento de 1996 (Tabela 4.9, pág. 86). A partir de setembro de 1998, a ETE de Jundiaí reduzia a carga de seu efluente em $85 \%$. Com o objetivo de obter uma aproximação maior do cenário real de cargas do rio, a redução de carga no efluente da ETE foi realizada após a calibração do modelo.

As Tabelas 4.11 e 4.12 apresentam a velocidade média e a profundidade média em cada trecho do rio Jundiaí. Estes dados foram utilizados para a escolha da fórmula a ser utilizada para o cálculo do coeficiente de reaeração $\left(\mathrm{K}_{2}\right)$. Os dados de profundidade média também foram utilizados para o cálculo do coeficiente de sedimentação $\left(\mathrm{K}_{3}\right)$, assim como a velocidade média de sedimentação foi adotada, mediante o processo de calibração, em aproximadamente 5,5 m/dia. (Ver Tabelas 4.13 e 4.14)

Tabela 4.11 - Velocidade média no rio Jundiaí

\begin{tabular}{|c|r|r|r|r|}
\cline { 2 - 5 } \multicolumn{1}{c|}{} & \multicolumn{4}{|c|}{ Velocidade Média (m/s) } \\
\hline Trecho & jan/fev/mar & abr/maio/jun & jul/ago/set & out/nov/dez \\
\hline \hline 1 & 0,432 & 0,392 & 0,367 & 0,399 \\
\hline 2 & 0,507 & 0,459 & 0,434 & 0,469 \\
\hline 3 & 0,560 & 0,510 & 0,475 & 0,521 \\
\hline 4 & 0,600 & 0,548 & 0,509 & 0,560 \\
\hline 5 & 0,626 & 0,570 & 0,527 & 0,583 \\
\hline 6 & 0,515 & 0,589 & 0,542 & 0,603 \\
\hline 7 & 0,543 & 0,462 & 0,420 & 0,488 \\
\hline 8 & 0,569 & 0,493 & 0,451 & 0,520 \\
\hline 9 & 0,593 & 0,516 & 0,465 & 0,543 \\
\hline 10 & 0,665 & 0,577 & 0,528 & 0,609 \\
\hline 11 & 0,644 & 0,557 & 0,508 & 0,588 \\
\hline 12 & 0,654 & 0,565 & 0,515 & 0,597 \\
\hline 13 & 0,671 & 0,579 & 0,528 & 0,613 \\
\hline 14 & 0,693 & 0,599 & 0,547 & 0,634 \\
\hline 15 & 0,710 & 0,614 & 0,561 & 0,650 \\
\hline
\end{tabular}


Tabela 4.12 - Profundidade média no rio Jundiaí

\begin{tabular}{|c|r|r|r|r|}
\cline { 2 - 5 } \multicolumn{1}{c|}{} & \multicolumn{4}{c|}{ Profundidade Média (m) } \\
\hline Trecho & jan/fev/mar & abr/maio/jun & jul/ago/set & out/nov/dez \\
\hline \hline 1 & 1,469 & 1,432 & 1,409 & 1,439 \\
\hline 2 & 1,531 & 1,492 & 1,471 & 1,500 \\
\hline 3 & 1,571 & 1,530 & 1,508 & 1,541 \\
\hline 4 & 1,599 & 1,557 & 1,533 & 1,570 \\
\hline 5 & 1,616 & 1,572 & 1,546 & 1,587 \\
\hline 6 & 1,974 & 1,585 & 1,557 & 1,600 \\
\hline 7 & 2,069 & 1,751 & 1,575 & 1,859 \\
\hline 8 & 2,207 & 1,883 & 1,705 & 1,995 \\
\hline 9 & 2,308 & 1,979 & 1,800 & 2,094 \\
\hline 10 & 2,602 & 2,223 & 2,014 & 2,358 \\
\hline 11 & 2,528 & 2,153 & 1,944 & 2,288 \\
\hline 12 & 2,573 & 2,188 & 1,973 & 2,327 \\
\hline 13 & 2,647 & 2,249 & 2,029 & 2,395 \\
\hline 14 & 2,744 & 2,333 & 2,109 & 2,485 \\
\hline 15 & 2,818 & 2,398 & 2,172 & 2,554 \\
\hline
\end{tabular}

Tabela 4.13 - Fórmulas utilizadas para cálculo de $\mathrm{K}_{2}$ no rio Jundiaí

\begin{tabular}{|c|c|c|c|c|}
\cline { 2 - 5 } \multicolumn{1}{c|}{} & \multicolumn{4}{c|}{ Fórmula } \\
\hline \hline Trecho & jan/fev/mar & abr/maio/jun & jul/ago/set & out/nov/dez \\
\hline \hline 1 & O'Connor-Dobbins & O'Connor-Dobbins & O'Connor-Dobbins & O'Connor-Dobbins \\
\hline 2 & O'Connor-Dobbins & O'Connor-Dobbins & O'Connor-Dobbins & O'Connor-Dobbins \\
\hline 3 & Churchill & O'Connor-Dobbins & O'Connor-Dobbins & O'Connor-Dobbins \\
\hline 4 & Churchill & O'Connor-Dobbins & O'Connor-Dobbins & Churchill \\
\hline 5 & Churchill & Churchill & O'Connor-Dobbins & Churchill \\
\hline 6 & O'Connor-Dobbins & Churchill & O'Connor-Dobbins & Churchill \\
\hline 7 & O'Connor-Dobbins & O'Connor-Dobbins & O'Connor-Dobbins & O'Connor-Dobbins \\
\hline 8 & Churchill & O'Connor-Dobbins & O'Connor-Dobbins & O'Connor-Dobbins \\
\hline 9 & Churchill & O'Connor-Dobbins & O'Connor-Dobbins & O'Connor-Dobbins \\
\hline 10 & Churchill & Churchill & O'Connor-Dobbins & Churchill \\
\hline 11 & Churchill & Churchill & O'Connor-Dobbins & Churchill \\
\hline 12 & Churchill & Churchill & O'Connor-Dobbins & Churchill \\
\hline 13 & Churchill & Churchill & O'Connor-Dobbins & Churchill \\
\hline 14 & Churchill & Churchill & O'Connor-Dobbins & Churchill \\
\hline 15 & Churchill & Churchill & Churchill & Churchill \\
\hline
\end{tabular}

$\mathrm{K}_{2}$ - Parâmetro de reaeração 
Tabela 4.14 - Valores de $\mathrm{K}_{3}$ para o rio Jundiaí

\begin{tabular}{|cr|r|r|r|}
\cline { 2 - 5 } \multicolumn{1}{c|}{} & \multicolumn{4}{c|}{ K3 (1/dia) } \\
\hline Trecho & jan/fev/mar & abr/maio/jun & jul/ago/set & out/nov/dez \\
\hline \hline 1 & 3,74 & 3,84 & 4,00 & 3,82 \\
\hline 2 & 3,59 & 3,69 & 3,82 & 3,67 \\
\hline 3 & 3,50 & 3,60 & 3,69 & 3,57 \\
\hline 4 & 3,44 & 3,53 & 3,65 & 3,50 \\
\hline 5 & 3,40 & 3,50 & 3,62 & 3,47 \\
\hline 6 & 2,79 & 3,47 & 3,59 & 3,44 \\
\hline 7 & 2,66 & 3,14 & 3,55 & 2,96 \\
\hline 8 & 2,49 & 2,92 & 3,21 & 2,76 \\
\hline 9 & 2,38 & 2,78 & 3,08 & 2,63 \\
\hline 10 & 2,11 & 2,47 & 2,69 & 2,33 \\
\hline 11 & 2,18 & 2,56 & 2,80 & 2,40 \\
\hline 12 & 2,14 & 2,51 & 2,78 & 2,36 \\
\hline 13 & 2,08 & 2,45 & 2,67 & 2,30 \\
\hline 14 & 2,00 & 2,36 & 2,56 & 2,21 \\
\hline 15 & 1,95 & 2,29 & 2,48 & 2,15 \\
\hline
\end{tabular}

$\mathrm{K}_{3}$ - Parâmetro de sedimentação

A Tabela 4.15 apresenta valores utilizados no processo de calibração para o coeficiente de degradação da matéria orgânica $\left(\mathrm{K}_{1}\right)$. Os valores adotados estão compreendidos entre os valores sugeridos por CHAPRA (1997).

$\mathrm{Na}$ Tabela 4.16 são apresentados os valores das variáveis OD e DBO ao longo do rio Jundiaí, diante de dados de vazão média trimestral. É também ressaltado o ponto de localização dos postos de monitoramento de qualidade da água (JUNA-2020 e JUNA4270), com o objetivo de mostrar o valor calculado compreendido entre os valores $50 \%$ mais freqüentes da série observada, para as variáveis $\mathrm{OD}$ e $\mathrm{DBO}$, nos respectivos trimestres.

Para uma melhor visualização entre valores calculados e observados foram utilizados "box plots" que representam estatisticamente a porcentagem de distribuição da variável observada. A Figura 4.16 mostra como foram construídos os "box plots". 
Tabela 4.15 - Valores de $\mathrm{K}_{1}$ para o rio Jundiaí

\begin{tabular}{|c|r|r|r|r|}
\cline { 2 - 5 } \multicolumn{1}{c|}{} & \multicolumn{4}{c|}{ K1 (1/dia) } \\
\hline \hline Trecho & jan/fev/mar & abr/maio/jun & jul/ago/set & out/nov/dez \\
\hline \hline 1 & 0,10 & 0,09 & 0,14 & 0,10 \\
\hline 2 & 0,10 & 0,09 & 0,14 & 0,10 \\
\hline 3 & 0,12 & 0,11 & 0,20 & 0,12 \\
\hline 4 & 0,15 & 0,13 & 0,20 & 0,15 \\
\hline 5 & 0,15 & 0,13 & 0,20 & 0,15 \\
\hline 6 & 0,15 & 0,13 & 0,20 & 0,15 \\
\hline 7 & 0,15 & 0,13 & 0,20 & 0,15 \\
\hline 8 & 0,30 & 0,22 & 0,35 & 0,30 \\
\hline 9 & 0,25 & 0,21 & 0,30 & 0,25 \\
\hline 10 & 0,22 & 0,16 & 0,30 & 0,20 \\
\hline 11 & 0,20 & 0,17 & 0,30 & 0,20 \\
\hline 12 & 0,20 & 0,19 & 0,30 & 0,20 \\
\hline 13 & 0,30 & 0,21 & 0,35 & 0,30 \\
\hline 14 & 0,30 & 0,21 & 0,35 & 0,30 \\
\hline 15 & 0,30 & 0,21 & 0,35 & 0,30 \\
\hline
\end{tabular}

$\mathrm{K}_{1}$ - Parâmetro de decaimento (degradação)

Tabela 4.16 - Valores de OD e DBO no rio Jundiaí

\begin{tabular}{|c|c|c|c|c|c|c|c|c|}
\hline & $\mathrm{jan} / \mathrm{fev}$ & mar & $\mathrm{abr} / \mathrm{ma}$ & o/jun & jul/ago & & out/nov & dez \\
\hline Espaço & OD & DBO & OD & DBO & OD & DBO & OD & DBO \\
\hline$(\mathrm{km})$ & $(\mathrm{mg} / \mathrm{l})$ & $(\mathrm{mg} / \mathrm{l})$ & $(\mathrm{mg} / \mathrm{l})$ & $(\mathrm{mg} / \mathrm{l})$ & $(\mathrm{mg} / \mathrm{l})$ & $(\mathrm{mg} / \mathrm{l})$ & $(\mathrm{mg} / \mathrm{l})$ & $(\mathrm{mg} / \mathrm{l})$ \\
\hline 0 & 8,84 & 0,08 & 8,83 & 0,08 & 8,77 & 0,11 & 8,85 & 0,07 \\
\hline 5 & 8,45 & 0,23 & 8,42 & 0,24 & 8,29 & 0,29 & 8,47 & 0,22 \\
\hline 10 & 8,24 & 0,28 & 8,21 & 0,28 & 8,09 & 0,32 & 8,27 & 0,27 \\
\hline 15 & 8,16 & 0,29 & 8,14 & 0,28 & 8,04 & 0,30 & 8,19 & 0,27 \\
\hline 20 & 8,13 & 0,28 & 8,12 & 0,26 & 8,05 & 0,28 & 8,16 & 0,26 \\
\hline 25 & 7,94 & 1,38 & 7,95 & 1,85 & 7,91 & 2,23 & 7,94 & 1,75 \\
\hline 30 & 7,58 & 7,37 & 7,47 & 10,57 & 7,34 & 13,05 & 7,46 & 10,13 \\
\hline 35 & 7,53 & 5,10 & 7,44 & 7,10 & 7,31 & 8,62 & 7,43 & 6,71 \\
\hline 40 & 7,19 & 10,45 & 6,97 & 14,86 & 6,71 & 18,20 & 6,97 & 13,39 \\
\hline 45 & 7,24 & 6,89 & 7,03 & 9,51 & 6,81 & 11,38 & 7,02 & 8,58 \\
\hline 50 & 7,33 & 4,65 & 7,16 & 6,18 & 6,99 & 7,20 & 7,14 & 5,60 \\
\hline 55 & 7,40 & 3,13 & 7,30 & 3,98 & 7,20 & 4,41 & 7,28 & 3,66 \\
\hline 60 & 7,48 & 2,18 & 7,45 & 2,50 & 7,41 & 2,56 & 7,40 & 2,39 \\
\hline 65 & 6,49 & 47,77 & 6,14 & 69,96 & 5,72 & 88,15 & 6,14 & 60,90 \\
\hline 70 & 5,25 & 35,08 & 4,69 & 47,84 & 3,84 & 56,93 & 4,54 & 42,62 \\
\hline 75 & 4,67 & 26,69 & 4,13 & 34,22 & 3,26 & 38,75 & 3,89 & 31,11 \\
\hline 80 & 4,45 & 20,16 & 4,03 & 24,36 & 3,34 & 26,23 & 3,66 & 22,57 \\
\hline 85 & 4,40 & 15,36 & 4,12 & 17,49 & 3,63 & 17,91 & 3,67 & 16,51 \\
\hline 90 & 4,47 & 11,78 & 4,30 & 12,61 & 4,02 & 12,27 & 3,82 & 12,16 \\
\hline 95 & 4,61 & 9,29 & 4,52 & 9,42 & 4,41 & 8,81 & 4,05 & 9,28 \\
\hline 100 & 4,72 & 7,24 & 4,74 & 6,91 & 4,78 & 6,13 & 4,25 & 6,95 \\
\hline 105 & 4,71 & 9,54 & 4,80 & 11,00 & 4,91 & 11,97 & 4,30 & 10,25 \\
\hline 110 & 4,74 & 7,54 & 4,92 & 8,23 & 5,09 & 8,52 & 4,37 & 7,80 \\
\hline 115 & 4,82 & 6,00 & 5,08 & 6,21 & 5,32 & 6,12 & 4,51 & 5,99 \\
\hline 120 & 4,94 & 4,82 & 5,26 & 4,73 & 5,55 & 4,45 & 4,67 & 4,65 \\
\hline 123 & 4,87 & 6,97 & 5,16 & 8,13 & 5,38 & 8,90 & 4,60 & 7,50 \\
\hline
\end{tabular}




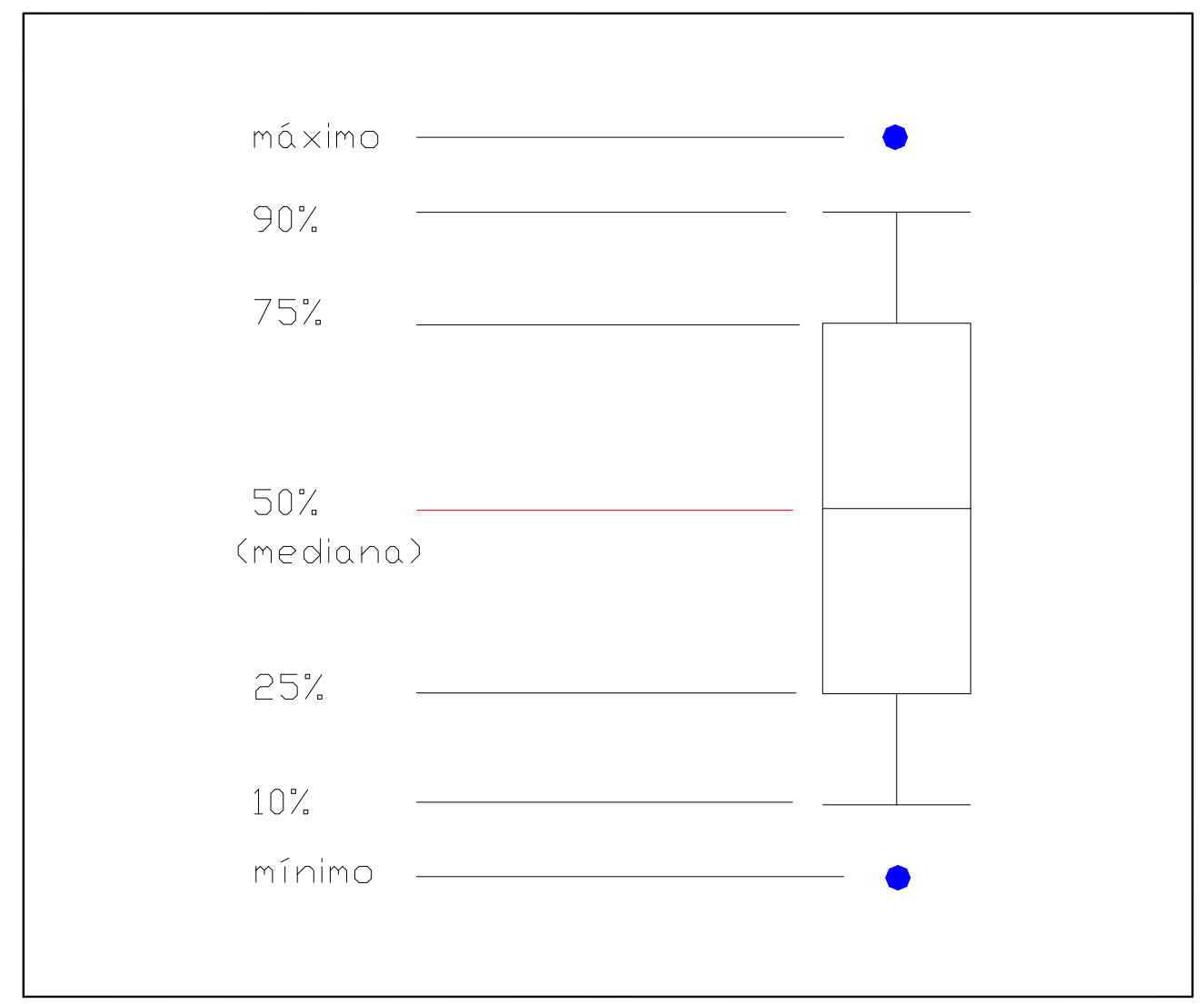

Fonte: UNEP (1995)

Figura 4.16 - Representação “box plots" utilizada para a calibração do modelo QUAL2E

As Figuras 4.17 a 4.24 mostram, para o cenário de cargas lançadas no rio Jundiaí, a variação da concentração de OD e DBO comparando os valores simulados com valores observados representados por "box plots". 
Figura 4.17 - Variação do OD para os meses de jan/fev/mar

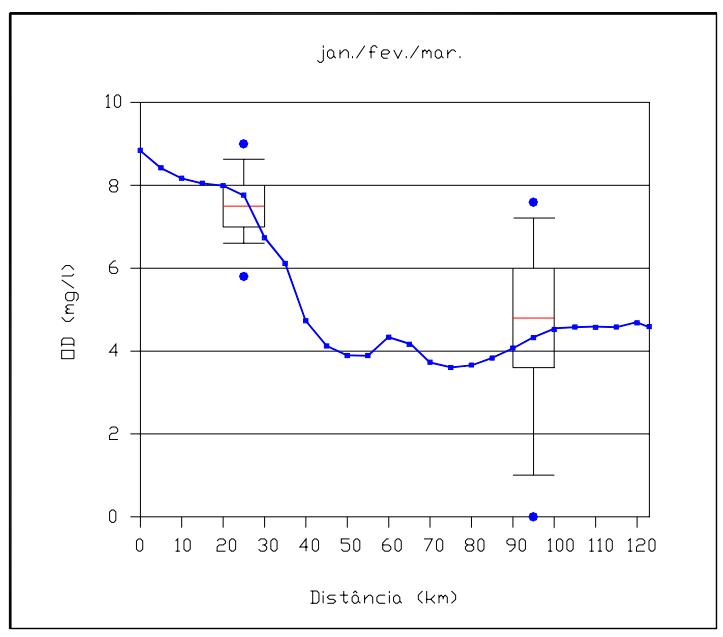

Figura 4.19 - Variação do OD para os meses de abr/maio/jun

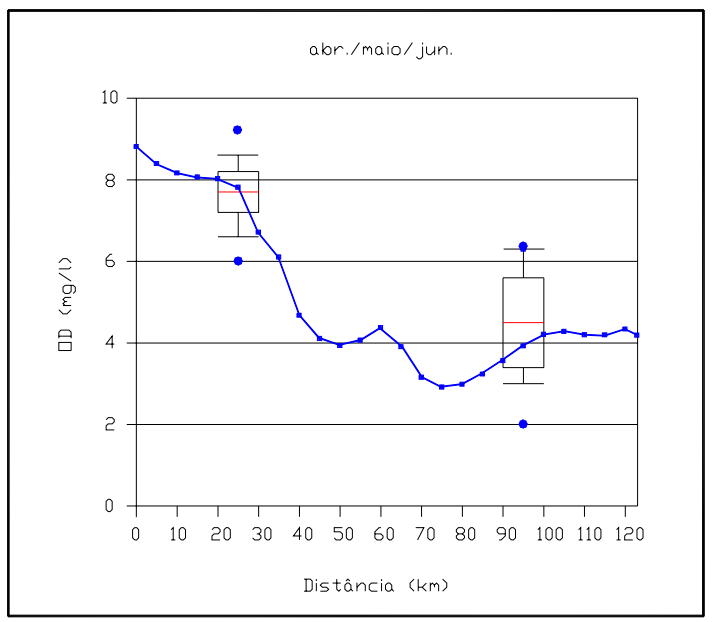

Figura 4.18 - Variação da DBO para os meses de jan/fev/mar

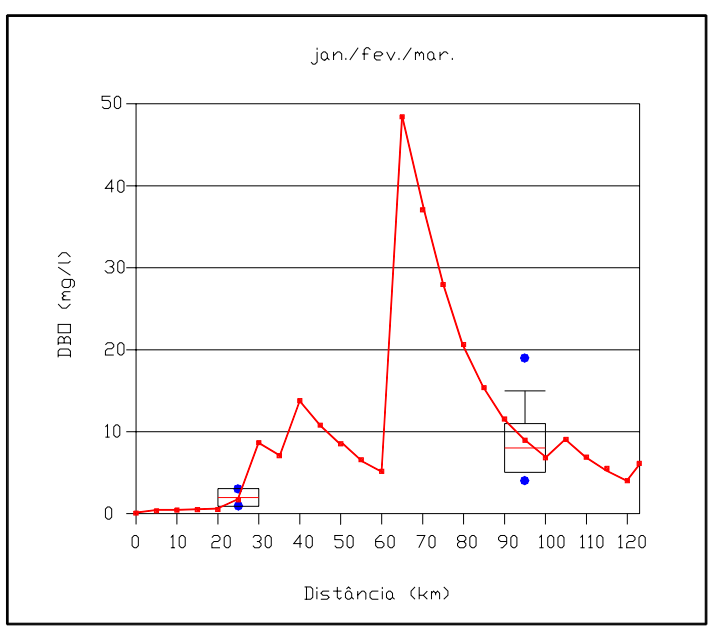

Figura 4.20 - Variação da DBO para os meses de abr/maio/jun

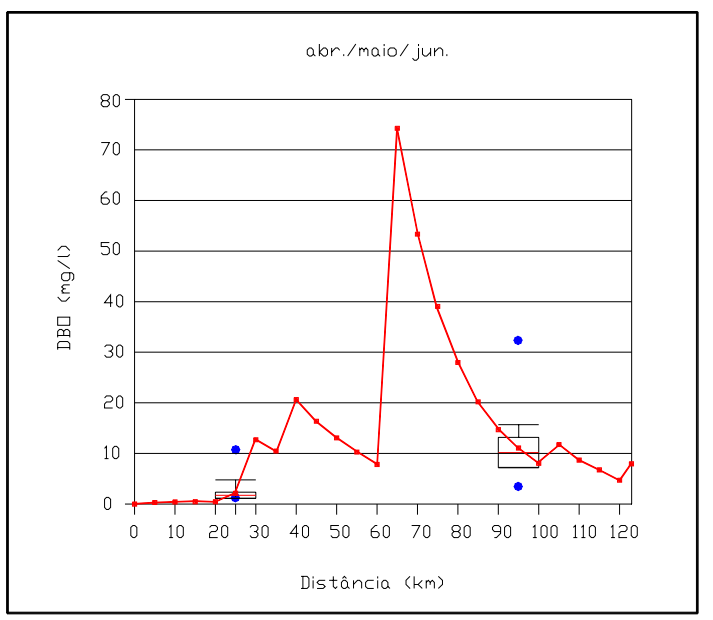


Figura 4.21 - Variação do OD para os meses de jul/ago/set

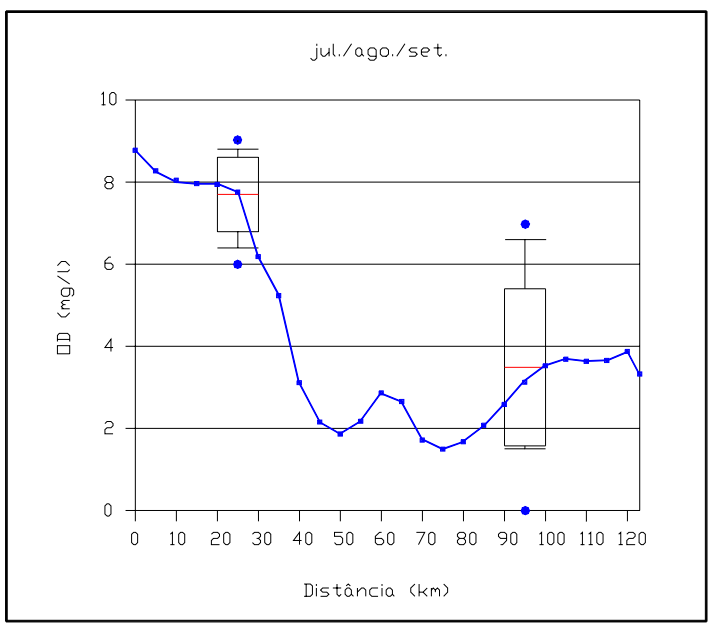

Figura 4.23 - Variação do OD para os meses de out/nov/dez

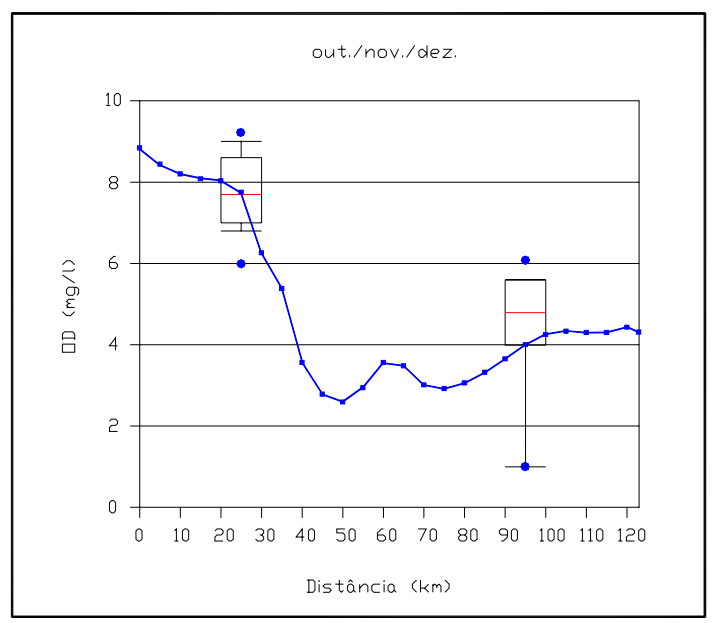

Figura 4.22 - Variação da DBO para os meses de jul/ago/set

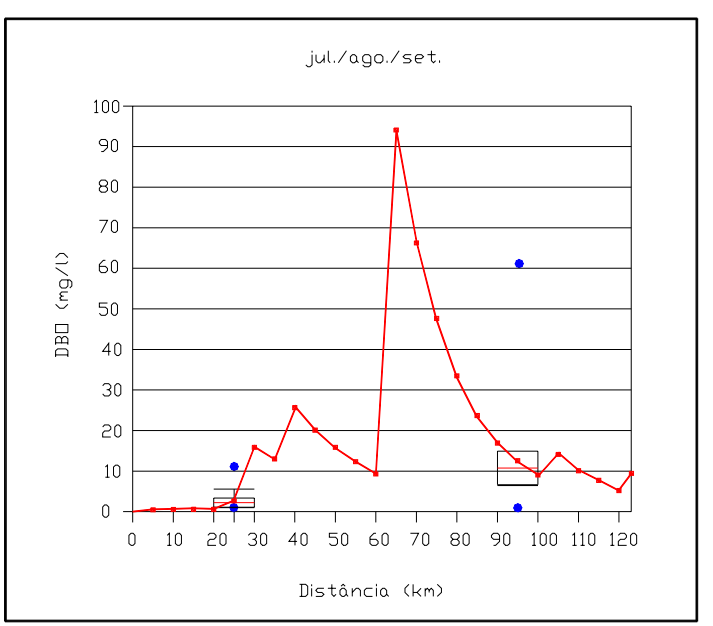

Figura 4.24 - Variação da DBO para os meses de out/nov/dez

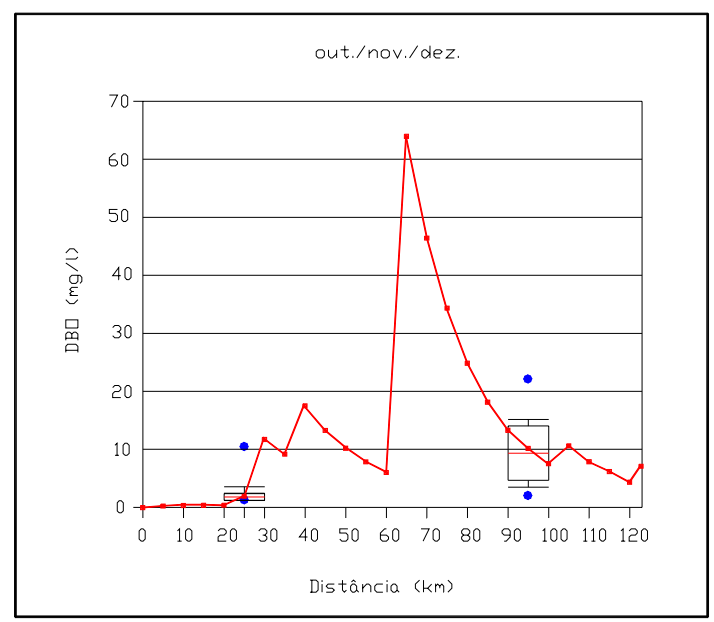

O conjunto de valores obtidos para os parâmetros de ajustes, dentro de cada período, foi utilizado para representar os cenários de vazões $\mathrm{Q}_{7,10}, \mathrm{Q}_{95}, \mathrm{Q}_{90}$ e Qm, de acordo com a melhor aproximação dos valores de vazão entre os mesmos. (Ver Tabela 4.17) 
Tabela 4.17 - Valores de vazão em regime $\mathrm{Q}_{7,10}, \mathrm{Q}_{95}, \mathrm{Q}_{90}$ e Qm

\begin{tabular}{|c|c|c|c|r|}
\cline { 2 - 6 } \multicolumn{1}{c|}{} & \multicolumn{5}{c|}{ Regime de vazão } \\
\hline Posto & $\begin{array}{c}\mathrm{Q}_{7,10} \\
\left(\mathrm{~m}^{3} / \mathrm{s}\right)\end{array}$ & $\begin{array}{c}\mathrm{Q}_{95} \\
\left(\mathrm{~m}^{3} / \mathrm{s}\right)\end{array}$ & $\begin{array}{c}\mathrm{Q}_{90} \\
\left(\mathrm{~m}^{3} / \mathrm{s}\right)\end{array}$ & $\begin{array}{c}\mathrm{Q}_{\mathrm{m}} \\
\left(\mathrm{m}^{3} / \mathrm{s}\right)\end{array}$ \\
\hline \hline 3E-108 & 0,35 & 0,76 & 0,85 & 1,66 \\
\hline $4 \mathrm{E}-017$ & 2,54 & 3,94 & 4,41 & 10,33 \\
\hline
\end{tabular}

Fonte: Adaptado de SECRETARIA DE RECURSOS HÍDRICOS, SANEAMENTO E OBRAS (1999)

$\mathrm{Q}_{7,10}$ - Vazão média mínima de sete dias consecutivos com período de retorno de 10 anos.

$Q_{95}$ - Vazão com garantia de $95 \%$ de permanência dentro da série histórica de dados observada.

$\mathrm{Q}_{90}$ - Vazão com garantia de $90 \%$ de permanência dentro da série histórica de dados observada.

Qm - Vazão média dentro da série histórica de dados observada.

Para os regimes de vazão $\mathrm{Q}_{7,10}, \mathrm{Q}_{95}, \mathrm{Q}_{90}$ adotaram-se valores médios de vazão dos meses de julho, agosto e setembro. Já para o regime de vazão Qm, adotaram-se valores médios de vazão dos meses de outubro, novembro e dezembro. 


\section{Capítulo 5}

\section{RESULTADOS E DISCUSSÕES}

\subsection{Apresentação do sistema de suporte a decisão RB}

O SSD RB, desenvolvido neste trabalho, visa subsidiar a gestão de recursos hídricos em bacias com múltiplos usos, oferecendo condições para que os processos de outorga e cobrança pelo uso da água sejam analisados de forma integrada e articulada com os demais instrumentos de gestão da Política Nacional de Recursos Hídricos. O SSD RB trabalha com cenários diversificados de vazão, dados hidráulicos, parâmetros, fluxo incremental, condições de cabeceira e condições iniciais do rio, permitindo uma saída gráfica de comparação entre os resultados obtidos para os mesmos. Valores "default" são fornecidos para auxiliar o usuário no processo de entrada de dados. Algumas simplificações foram estabelecidas para melhor afinidade do usuário ao sistema. O SSD RB pode ser obtido através do site www.rbrecursoshidricos.com.

\subsection{Manual do SSD RB}

As informações contidas neste manual são para auxiliar o usuário na utilização do SSD RB. Para uso do SSD RB, recomenda-se também a consulta da dissertação de mestrado de RODRIGUES (2000) e do manual do modelo QUAL2E The Enhanced Stream Water Quality Models QUAL2E and QUAL2E-UNCAS, desenvolvido por BROWN e BARNWELL (EPA/600/3-87/007). Estes trabalhos discutem a teoria dos modelos utilizados no SSD RB e fornecem maiores orientações sobre aplicações. 


\subsubsection{Fatores considerados pelo SSD RB para os processos de outorga e cobrança pelo uso da água}

Os fatores considerados pelo Sistema de Suporte a Decisão RB para conceder a outorga solicitada e calcular o custo de lançamento e/ou captação na bacia hidrográfica são:

- Localização da outorga solicitada na rede hidrográfica;

- Disponibilidade de água;

- Qualidade da água;

- Enquadramento do rio;

- Grau de prejuízo do lançamento do usuário-poluidor aos usuários de jusante;

- Quantidade de água solicitada;

- Localização das outorgas já concedidas na rede hidrográfica;

- Usos da água a montante e a jusante do local em estudo;

- Série histórica de dados qualitativos e quantitativos da bacia hidrográfica;

- Características hidráulicas do corpo hídrico;

- Capacidade de autodepuração do corpo hídrico;

- Associação do custo de captação da água à qualidade da água captada, ou seja, quanto melhor a qualidade da água captada, mais paga o usuário, assim como quanto mais degradada a qualidade da água, menos paga o usuário;

- Associação do custo de lançamento do usuário-poluidor aos prejuízos ocasionados aos usuários de jusante, em termos de qualidade da água.

\subsubsection{Limitações e medidas de contorno do SSD RB}

As limitações computacionais do SSD RB, na versão 1.00, são:

- Número de Trecho:

- Elemento Computacional:

- Elemento de Cabeceira:

- Elemento de Junção:

- Elementos de Lançamento ou Captação:
No máximo 200;

Não mais do que 20 por trecho e 2000 no total;

No máximo 10 ;

No máximo 9;

No máximo 200. 
Estas limitações são as mesmas que a do modelo QUAL2E, na versão 3.22, de maio de 1996. Ressalte-se que nova versão do SSD RB está sendo desenvolvida para contornar as respectivas limitações.

O modelo QUAL2E oferece a possibilidade de se trabalhar apenas com um cenário de dados de entrada no modelo. Através do SSD RB, é possível trabalhar com 20 cenários de dados de entrada, podendo haver combinações entre:

- Dados Hidráulicos;

- Dados de Cabeceira;

- Dados de Condição Inicial do Rio;

- Poluição Difusa;

- Parâmetros e Coeficientes;

- Custos Unitários;

- Classe de Uso.

Os resultados dessas simulações são apresentados de forma tabular e gráfica, havendo a possibilidade de combinações entre os mesmos.

\subsubsection{Especificação de hardware e software}

O SSD RB requer aproximadamente 5.0 MB de espaço livre em disco. CPU Pentium 4, 2000 Mhz ou superior, com no mínimo 64 megabytes de RAM. Windows 98, 2000, NT ou XP, configurado em Super VGA 800 x 600 pixels, e com número decimal de ‘Configurações Regionais' do Windows configurado com ponto (.).

\subsubsection{Instalação}

A partir do Windows, insira o $C D$ no "drive" de CD-ROM, clique em SETUP.EXE dentro do $C D-R O M$. 


\subsubsection{Simplificações estabelecidas}

Devido à baixa concentração de algas em corpos de água de média a alta velocidade, como rios e córregos, e à falta de dados históricos de monitoramento de concentração de algas para rios e córregos, a variável Alga foi retirada como opção de simulação do SSD $\mathrm{RB}$, assim como a variável temperatura é simulada apenas no estado estacionário (Versão 1.00). A variável Coliforme também foi retirada como opção de simulação do SSD RB, devido a grande instabilidade desta variável no corpo hídrico, desta forma julgou-se não aconselhável tê-la como uma variável de decisão para os processos de outorga e cobrança pelo uso da água.

\subsubsection{Dados de entrada}

Os dados de entrada são apresentados em 6 formulários, sendo:

- Formulário 1: Identificação;

- Formulário 2: DH, Geográficos e Climáticos;

- Formulário 3: Variável de QA;

- Formulário 4: Const. de Reação e Condição Inicial;

- Formulário 5: Cabeceira e Fluxo Incremental;

- Formulário 6: Coef., Lanç. e Cap.;

- Formulário 7: Enquadramento e VMP.

Ao entrar no sistema, o formulário 'Inicializar' fica disponível para o usuário (Ver Figura 5.1). Neste formulário, o usuário pode escolher as opções:

- Novo: Cria um novo arquivo;

- Existente: Abre um arquivo existente, após a escolha do mesmo na caixa de listagem de arquivos. $\mathrm{O}$ arquivo também pode ser aberto através de dois cliques simultâneos no nome escolhido pelo usuário;

- Cancelar: Sai da tela. 


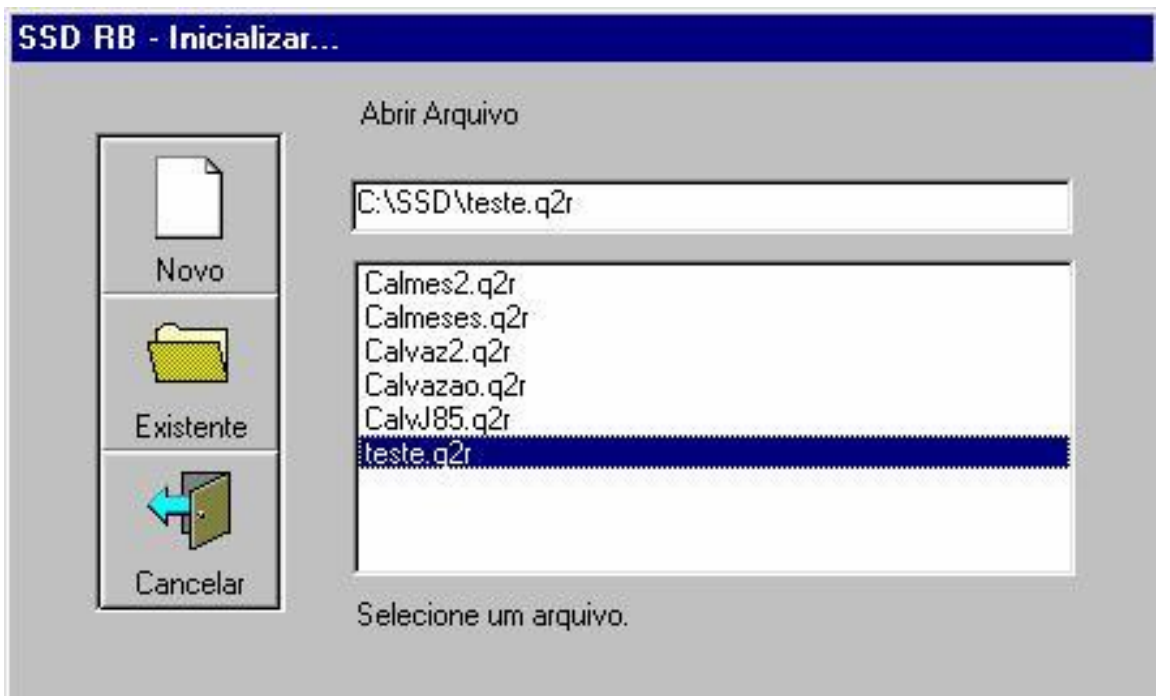

Figura 5.1 - Formulário de inicialização

Após o usuário ter escolhido a opção 'Novo' ou 'Existente', o formulário de 'Identificação' fica disponível. (Ver Figura 5.2)

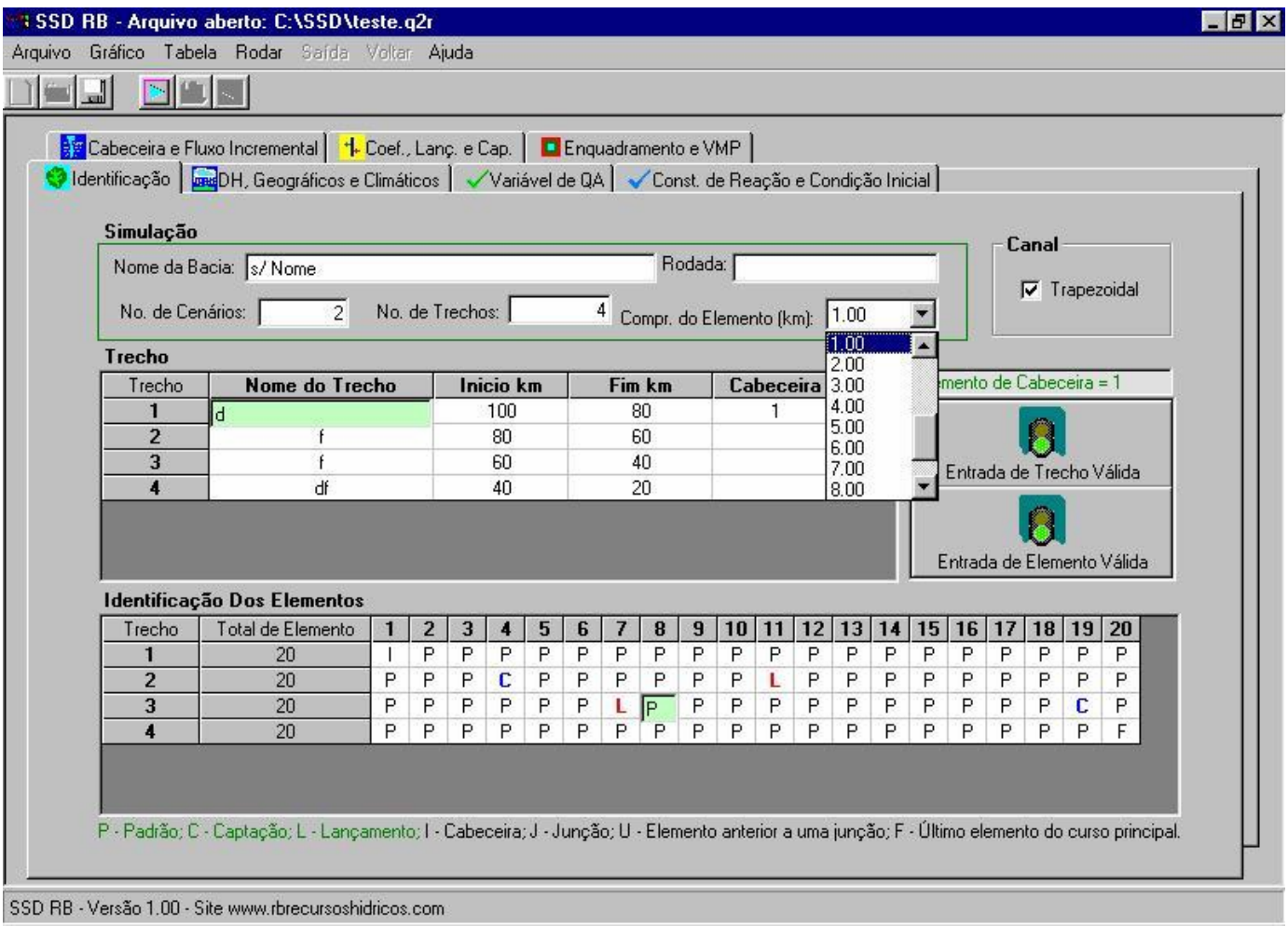

Figura 5.2 - Formulário de Identificação (Rodada, Trecho, Elemento) 
No formulário da Figura 5.2, entram-se os seguintes dados:

- Nome da Bacia:

- Rodada:

- Cenários:

- Número de Trechos:

- Comprimento do Elemento:

- Trapezoidal:

- Trecho:
Nome da bacia que será simulada;

Identificação da simulação;

Número de cenários a serem simulados. Após entrar com o número de cenários a ser simulado, pressionar a tecla ENTER;

Número de trechos em que o rio será segmentado;

Comprimento do elemento computacional para simulação. A escolha do usuário pode variar de $0,1 \mathrm{~km}$ a $10 \mathrm{~km}$. O número mínimo de elemento por trecho é dois e o número máximo é vinte;

A entrada pode ser feita considerando o canal como trapezoidal ou através do uso de coeficientes de descarga, sendo:

$\mathrm{U}=\mathrm{aQ}^{\mathrm{b}}$ e $\mathrm{H}=\alpha \mathrm{Q}^{\beta}$. Onde:

$\mathrm{U}=$ velocidade $(\mathrm{m} / \mathrm{s}) ; \mathrm{H}=$ profundidade $(\mathrm{m})$

$\mathrm{Q}=\operatorname{vazão}\left(\mathrm{m}^{3} / \mathrm{s}\right) ; \mathrm{a}, \mathrm{b}, \alpha$ e $\beta=$ coeficientes de descarga;

Nesta grade, são inseridos o inicio e o fim de cada trecho, assim como a identificação dos elementos de cabeceira. Caso o elemento seja de cabeceira, este deverá ser identificado com o número 1 , lembrando que o elemento de cabeceira é representado pelo máximo comprimento do rio ou trecho afluente, e o número do elemento da foz é 0 . (Ver manual do modelo QUAL2E). 
Os elementos no SSD RB têm as seguintes designações:

- I: Elemento de Cabeceira: primeiro elemento do trecho inicial de uma ramificação;

- J : Elemento de Junção: elemento que recebe um afluente;

- U: Elemento de União: representa o elemento anterior a uma junção;

- F : Elemento Final: ultimo elemento do curso principal do sistema de rios;

- P: Elemento Padrão: elemento que não possui nenhuma das designações anteriores, mas que pode vir a ser designado como Elemento de Captação (C) ou Elemento de Lançamento (L);

- C: Elemento de Captação: elemento em que ocorre o processo de retirada de água;

- L: Elemento de Lançamento: elemento em que ocorre o processo de lançamento de um efluente.

Ressalte-se que cada elemento do protótipo do sistema simulado só pode ter uma única designação.

Após os dados da grade 'Trecho' terem sido inseridos, existe a necessidade de os mesmos serem validados. Clique no botão 'Validar Trecho'. Caso os valores inseridos forem válidos, aparece a seguinte mensagem no botão clicado: Entrada de Trecho Válida. Acende uma luz verde e o botão 'Validar Elemento' fica disponível, assim como os elementos de Junção, Cabeceira, União e Final, são identificados automaticamente na grade 'Identificação de Elementos'. Caso os dados não forem válidos, o sistema auxilia o usuário na identificação do erro para posterior validação.

Estando os dados da grade 'Trechos' válidos, existe a necessidade de validar os dados da grade 'Identificação de Elementos'. Para isso, escolha na grade os pontos de Lançamento (L) e/ou Captação (C) através de dois cliques simultâneos na célula designada como elemento padrão (P). Após inserir os pontos de lançamento e captação, pressione o botão 'Validar Elemento'. 
Com os dados das grades 'Trecho' e 'Identificação dos Elementos' validados, os controles dos demais formulários ficam disponíveis para entrada de dados, assim como são identificados nas grades 'Dados de Cabeceira' e 'Lançamentos e Captações' os dados de Nome do Trecho, Trecho e Número do Elemento com suas respectivas designações.

Após os dados das grades 'Trecho' e 'Identificação de Elementos' terem sido validados, caso os mesmos ou os dados de Comprimento do Elemento sejam alterados, o processo de validação perde sua validade e os dados das grades 'Dados de Cabeceira' e 'Lançamentos e Captações' são perdidos. Os dados não são perdidos se o arquivo já estiver salvo e as alterações não forem salvas.

O Formulário 5.2 (Dados Hidráulicos, Climáticos e Geográficos) apresenta as grades 'Dados Hidráulicos' e 'Dados Climáticos e Geográficos'. Na grade 'Dados Hidráulicos', os dados ficam disponíveis de acordo com a opção do usuário por Canal Trapezoidal ou não. (Ver Tabela 5.1 e Figura 5.3)

Os 'Dados hidráulicos' devem ser inseridos para cada cenário de simulação, e após a inserção dos mesmos, eles devem ser validados através do botão 'Validar Cenários'. Ao clicar no botão de validação, caso haja alguma incoerência nos dados inseridos, o usuário é informado pelo sistema.

Para facilitar o processo de inserção de dados, existe a opção de clicar na linha de título de identificação dos dados de coluna e inserir os dados de forma mais rápida através do formulário 'Inserção Rápida de Dados', apresentado no centro da Figura 5.3.

Nesse formulário, o usuário seleciona o trecho inicial e final do dado a ser inserido e entra com o respectivo valor. $\mathrm{O}$ valor digitado é inserido automaticamente na grade de dados. Este formulário está disponível para as grades: 'Dados Hidráulicos'; 'Constantes de Reação (OD e DBO)'; 'Condição Inicial do Rio'; 'Dados de Cabeceira'; 'Fluxo Incremental'; 'Coeficientes (N, P, Coliforme, Não-Conservativo)'. 


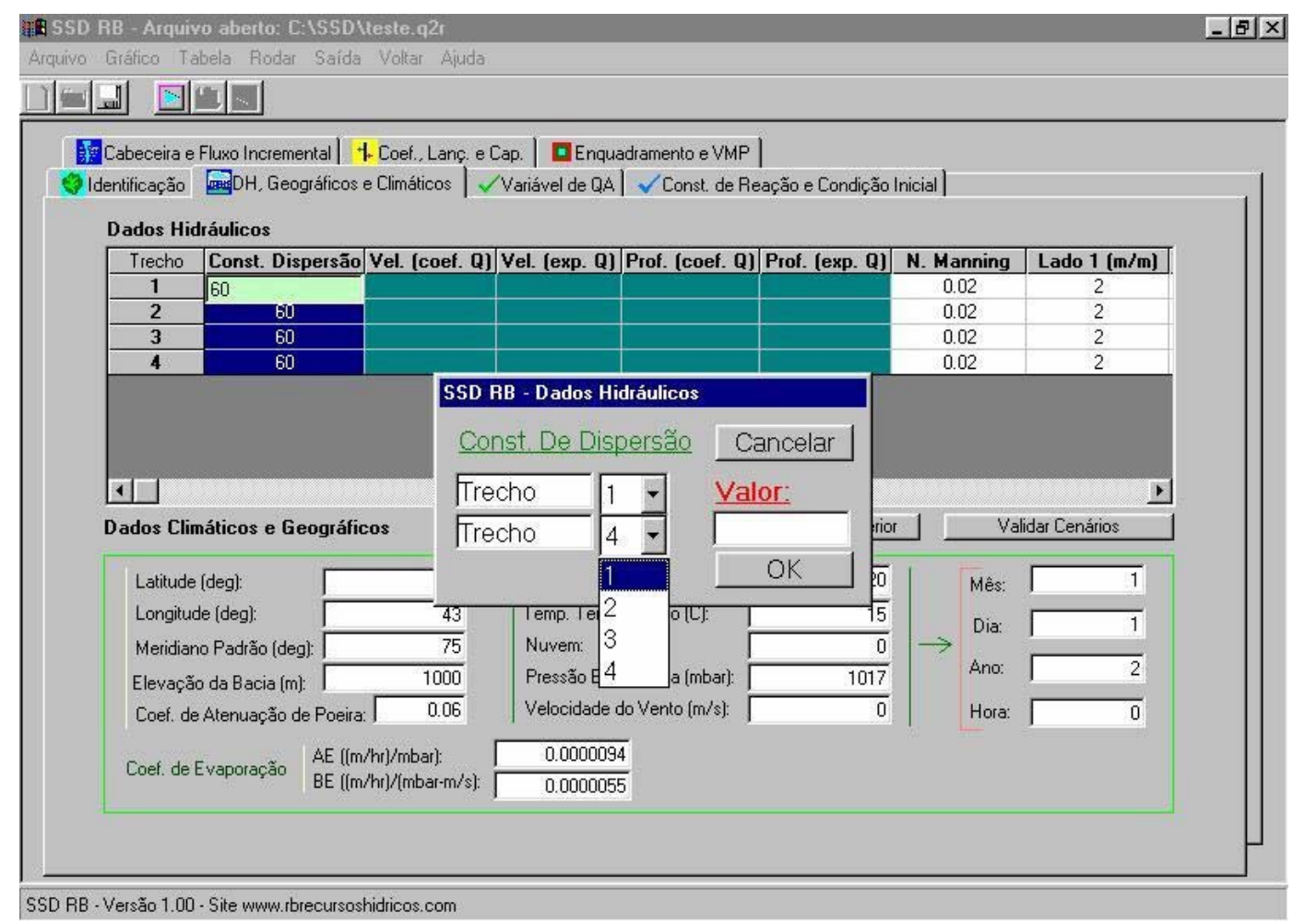

Figura 5.3 - Formulário de Dados Hidráulicos, Climáticos e Geográficos e Formulário de Inserção Rápida de Dados

Os Dados Climáticos e Geográficos apresentados no Formulário 2 são Latitude, Longitude, Meridiano Padrão, Elevação da Bacia, Coef. de Atenuação de Poeira, Temperatura em Tempo Seco, Temperatura em Tempo Úmido, Nuvem, Pressão Barométrica, Velocidade do Vento, Mês, Dia, Ano, Hora, Coeficiente de Evaporação AE e Coeficiente de Evaporação BE. (Ver Tabela 5.1) 
Tabela 5.1 - Caracterização dos dados Hidráulicos, Climáticos e Geográficos

\begin{tabular}{|c|c|c|c|c|c|}
\hline & Tipo & Valores Limites & Valor "Default" & Unidade & Canal Trapezoidal \\
\hline \multirow{10}{*}{ 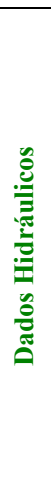 } & Constante de Dispersão & $6-6000$ & 60 & $\mathrm{~m}^{2} / \mathrm{dia}$ & Sim \\
\hline & Coeficiente Q de Velocidade & $0-$ & - & - & Não \\
\hline & Expoente Q de Velocidade & $0-1$ & - & - & Não \\
\hline & Coeficiente Q de Profundidade & $0-$ & - & - & Não \\
\hline & Expoente Q de Profundidade & $0-1$ & - & - & Não \\
\hline & Número de Manning & $0,001-0,05$ & 0,02 & - & Sim \\
\hline & Lado 1 do Canal & $0-1000$ & - & $\mathrm{m} / \mathrm{m}$ & Sim \\
\hline & Lado 2 do Canal & $0-1000$ & - & $\mathrm{m} / \mathrm{m}$ & Sim \\
\hline & Largura do Canal & $0-$ & - & $\mathrm{m}$ & Sim \\
\hline & Declividade do Canal & $0-1$ & 0 & $\mathrm{~m} / \mathrm{m}$ & Sim \\
\hline \multirow{13}{*}{ 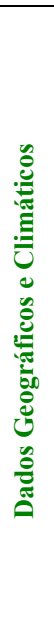 } & Tipo & Valores Limites & Valor "Default" & \multicolumn{2}{|c|}{ Unidade } \\
\hline & Latitude & $0-90$ & 23 & \multicolumn{2}{|r|}{ Graus } \\
\hline & Longitude & $0-180$ & 43 & \multicolumn{2}{|r|}{ Graus } \\
\hline & Meridiano Padrão & $0-180$ & 75 & \multicolumn{2}{|r|}{ Graus } \\
\hline & Elevação da Bacia & $(-120)-3650$ & 1000 & \multicolumn{2}{|r|}{$\mathrm{m}$} \\
\hline & Coeficiente de Atenuação de Poeira & $0,01-0,15$ & 0,06 & \multicolumn{2}{|r|}{-} \\
\hline & Coeficiente de Evaporação $\mathrm{AE}$ & $0,000005-0,000062$ & 0,0000094 & \multicolumn{2}{|c|}{$(\mathrm{m} / \mathrm{hr}) / \mathrm{mbar}$} \\
\hline & Coeficiente de Evaporação BE & $0,0000032-0,0000055$ & 0,0000032 & \multicolumn{2}{|c|}{$(\mathrm{m} / \mathrm{hr}) / \mathrm{mbar}-\mathrm{m} / \mathrm{s}$} \\
\hline & Temperatura no Tempo Seco & $2-50$ & 15 & \multicolumn{2}{|r|}{${ }^{\circ} \mathrm{C}$} \\
\hline & Temperatura no Tempo Úmido & $2-55$ & 20 & \multicolumn{2}{|r|}{${ }^{\circ} \mathrm{C}$} \\
\hline & Percentagem de Nuvem & $0-1$ & 0 & \multicolumn{2}{|r|}{-} \\
\hline & Pressão Barométrica & $900-1100$ & 1017 & \multicolumn{2}{|r|}{ mbar } \\
\hline & Velocidade do Vento & $0-36$ & 0 & \multicolumn{2}{|r|}{$\mathrm{m} / \mathrm{s}$} \\
\hline
\end{tabular}

Fonte: Adaptado de BROWN e BARNWELL (1987)

O Formulário 3 apresenta as Variáveis de Qualidade da Água e Fator de Correção de Temperatura. As variáveis disponíveis são: Oxigênio Dissolvido, Demanda Bioquímica de Oxigênio (DBO), Temperatura (simulação estática), Coliforme Fecal, Variável NãoConservativa, Fósforo, Nitrogênio e três Variáveis Conservativas. (Ver Tabela 5.2 e Figura 5.4) 
Tabela 5.2 - Caracterização dos dados de entrada das variáveis de qualidade da água

\begin{tabular}{|c|c|c|c|c|}
\hline Variável & Fator de Correção de Temperatura & Valores Limites & Valor "Default" & Unidade \\
\hline \multirow[t]{2}{*}{ OD } & Reaeração & $1-1,1$ & 1,024 & - \\
\hline & Consumo de OD do Sedimento & $1-1,1$ & 1,060 & - \\
\hline \multirow[t]{2}{*}{ DBO } & Decaimento (Degradação) & $1-1,1$ & 1,047 & - \\
\hline & Sedimentação & $1-1,1$ & 1,024 & - \\
\hline Coliforme Fecal & Decaimento & $1-1,1$ & 1,047 & - \\
\hline \multirow[t]{3}{*}{ Variável Não-Conservativa } & Decaimento & $1-1,1$ & 1,000 & - \\
\hline & Sedimentação & $1-1,1$ & 1,024 & - \\
\hline & Fonte & $1-1,1$ & 1,000 & - \\
\hline \multirow[t]{3}{*}{ Fósforo } & Decaimento P-Orgânico & $1-1,1$ & 1,047 & - \\
\hline & Sedimentação P-Orgânico & $1-1,1$ & 1,024 & - \\
\hline & Fonte P-Dissolvido & $1-1,1$ & 1,074 & - \\
\hline \multirow[t]{5}{*}{ Nitrogênio } & Decaimento N-Orgânico & $1-1,1$ & 1,047 & - \\
\hline & Sedimentação N-Orgânico & $1-1,1$ & 1,024 & - \\
\hline & Decaimento da Amônia & $1-1,1$ & 1,083 & - \\
\hline & Fonte de Amônia & $1-1,1$ & 1,074 & - \\
\hline & Decaimento do Nitrito & $1-1,1$ & 1,047 & - \\
\hline \multirow[t]{5}{*}{ A) Cinética Global } & Parâmetro & Valores Limites & Valor "Default" & Unidade \\
\hline & $\begin{array}{l}\text { Consumo de OD pela Oxidação da } \\
\text { Amônia }\end{array}$ & $3-3,5$ & 3,43 & $\begin{array}{c}\mathrm{mg} \mathrm{O} / \mathrm{mg} \mathrm{N}- \\
\mathrm{NH}_{3}\end{array}$ \\
\hline & $\begin{array}{l}\text { Consumo de OD pela Oxidação do } \\
\text { Nitrito }\end{array}$ & $1-1,2$ & 1,14 & $\begin{array}{c}\mathrm{mg} \mathrm{O} / \mathrm{mg} \mathrm{N}- \\
\mathrm{NH}_{3}\end{array}$ \\
\hline & Coef. Inibição da Nitrificação & $0-10$ & 10 & - \\
\hline & Coef. Conv. $\mathrm{DBO}_{5,20}$ para DBOu & $0-$ & 0,23 & - \\
\hline
\end{tabular}

Fonte: Adaptado de BROWN e BARNWELL (1987)

De acordo com as opções do usuário pelas variáveis acima citadas, os dados de entrada das grades 'Constantes de Reação (OD e DBO)', 'Condição Inicial do Rio', 'Dados de Cabeceira', 'Fluxo Incremental', 'Coeficientes (N, P, Coliforme, Não-Conservativo)' e ‘Carga Pontual e Captação’ ficam disponíveis.

Através da Figura 5.4, pode-se observar que o Formulário 3 também possibilita converter os dados de saída de $\mathrm{DBO}$ padrão $\left(5\right.$ dias, a $\left.20^{\circ} \mathrm{C}\right)$ para DBO última. Para a variável DBO, os dados de entrada são entendidos como DBO padrão. 


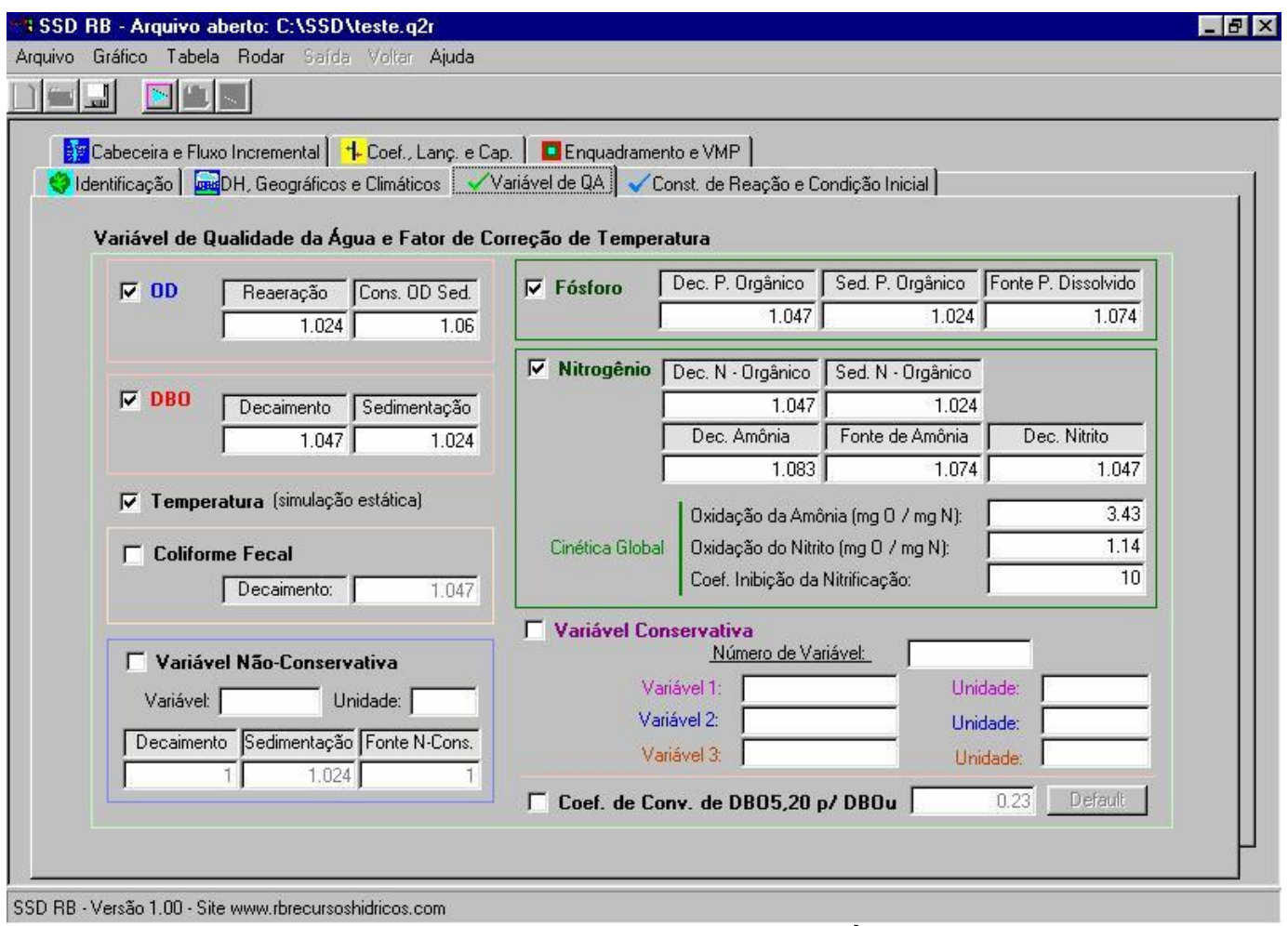

Figura 5.4 - Formulário de Variáveis de Qualidade da Água e Fator de Correção de Temperatura

No Formulário 4 (Constantes de Reação e Condição Inicial), encontram-se as grades 'Constantes de Reação (OD e DBO)' e 'Condição Inicial do Rio'. Para cada cenário simulado, deve ser inserido o respectivo conjunto de dados requerido no formulário; esses cenários devem ser validados através do botão 'Validar Cenários'. (Ver Figura $5.5)$

Na grade 'Constantes de Reação (OD e DBO)', para a variável DBO, são inseridos os dados de Coeficiente de Decaimento (degradação) e Coeficiente de Sedimentação. Para a variável OD, são inseridos os seguintes dados de Taxa de OD do Sedimento (demanda bentônica de oxigênio), Tipo de Reaeração, Coeficiente de Reaeração, Coef.K2 e Exp.K2 (constantes empíricas obtidas com o método de ajuste com os dados de campo, através da equação de potência), Declividade e Coef.TSIVG (coeficiente "c" da fórmula de TSIVOGLOU e WALLANCE, 1972, para o cálculo do parâmetro de reaeração $\mathrm{K}_{2}$ ). (Ver Tabela 5.3) 
Tabela 5.3 - Valores das constantes de reação de OD e DBO

\begin{tabular}{|l|l|c|c|c|}
\hline \multicolumn{1}{|c|}{ Variável } & \multicolumn{1}{|c|}{ Parâmetro } & Valores Limites & Valor "Default" & Unidade \\
\hline \multirow{4}{*}{ DBO } & Decaimento & $0-10$ & 0 & $1 / \mathrm{d}$ \\
\cline { 2 - 5 } & Sedimentação & $0-10$ & 0 & $1 / \mathrm{d}$ \\
\hline OD & Taxa de OD do Sedimento & $0-10$ & 0 & $\mathrm{~g} / \mathrm{m}^{2}-\mathrm{dia}$ \\
\cline { 2 - 5 } & Tipo de Reaeração & $1-8$ & 3 & - \\
\cline { 2 - 5 } & Coeficiente de Reaeração & $0-100$ & 0 & - \\
\cline { 2 - 5 } & Coeficiente de Q p/ K2 (Opção 7) & $0-$ & 0 & - \\
\cline { 2 - 5 } & Expoente de Q p/ K2 (Opção 7) & $0-$ & 0 & $1 / \mathrm{m}$ \\
\cline { 2 - 5 } & Coeficiente de TSIVG (Opção 8) & $0-$ & 0 & $\mathrm{~m} / \mathrm{m}$ \\
\cline { 2 - 5 } & Declividade (Opção 8) & $0-1$ & 0 & - \\
\hline
\end{tabular}

Fonte: Adaptado de BROWN e BARNWELL (1987)

No SSD RB, para visualizar as opções de entrada em 'Tipo de Reaeração', clicar na primeira linha da coluna correspondente, um formulário de auxílio fica disponível. (Ver

Figura 5.5)

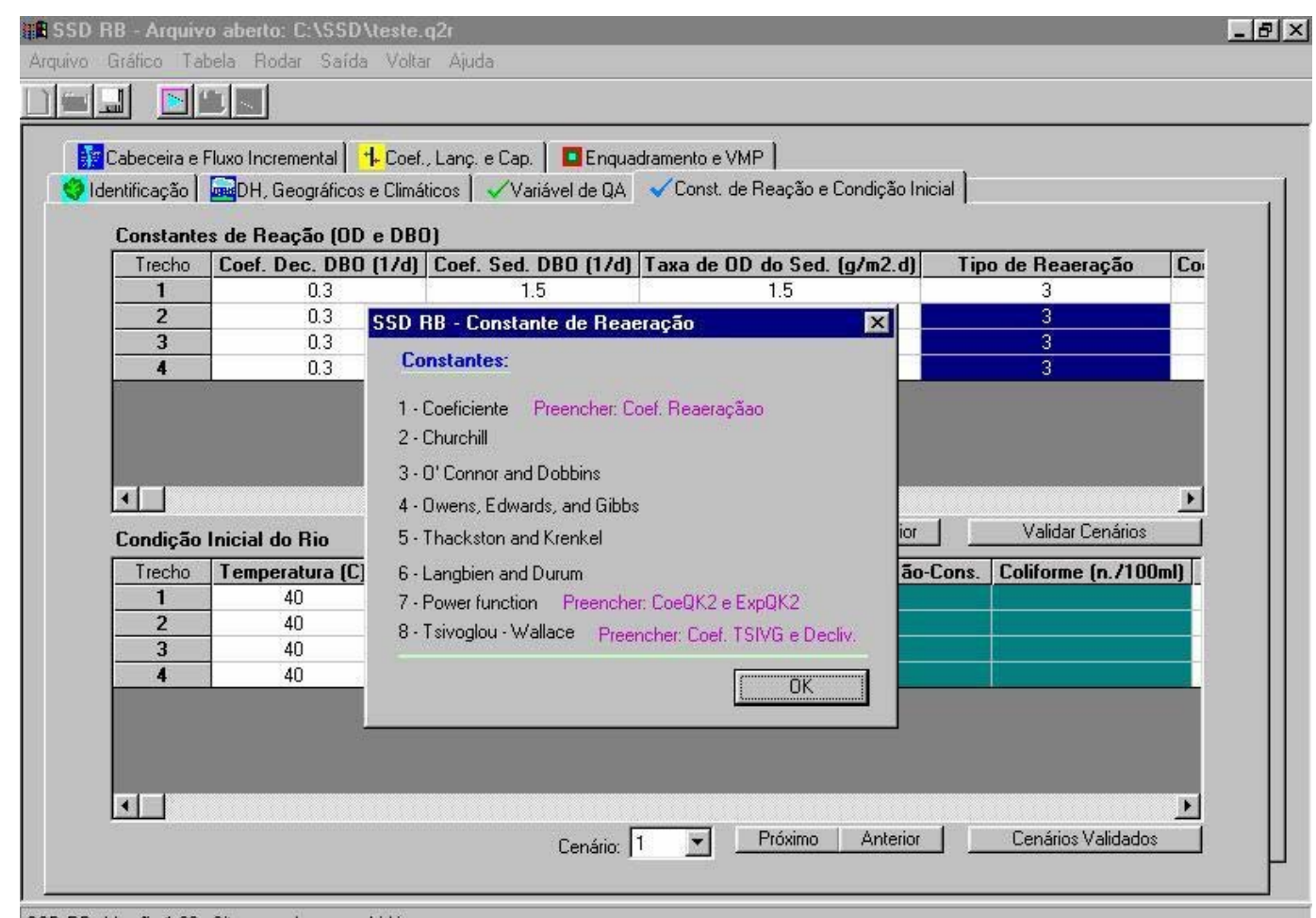

SSD RB - Versão 1.00 - Site www. brecursoshiddicos.com

Figura 5.5 - Formulário de Constantes de Reação (OD e DBO) e Condição Inicial do Rio

Para a entrada de dados 'Tipo de Reaeração', os valores a serem inseridos variam de um a oito, cujas opções correspondentes são: 
1 - Entrar com os dados manualmente (Preencher dados da coluna 'Coef. Reaeração');

2 - Churchill;

3 - O' Connor e Dobbins;

4 - Owens, Edwards, e Gibbs;

5 - Thackston e Krenkel;

6 - Langbien e Durum;

7 - Coeficientes da Equação de Potência (Preencher os dados das colunas 'CoeK2' e 'ExpK2');

8 - Tsivoglou e Wallace (Preencher dados das colunas 'Coef. TSIVG' e 'Declividade').

Na grade 'Condição Inicial do Rio', de acordo com as opções do usuário na escolha das variáveis de qualidade da água a serem simuladas, podem ser válidas as seguintes entradas: Temperatura, OD, DBO, Conservativo 1, Conservativo 2, Conservativo 3, Não-Conservativo, Coliforme Fecal, Nitrogênio Orgânico, Amônia, Nitrito, Nitrato, Fósforo orgânico e Fósforo Dissolvido. Esses dados representam os valores das variáveis no rio, antes do recebimento das cargas de lançamento. (Ver Tabela 5.4)

Tabela 5.4 - Dados de parâmetros e variáveis

\begin{tabular}{|c|c|c|c|}
\hline Parâmetro & Valores Limites & Valor "Default" & Unidade \\
\hline Tratamento (\%) & $0-1$ & 0 & - \\
\hline Vazão & $(-999)-999$ & - & $\mathrm{m}^{3} / \mathrm{s}$ \\
\hline Variável & Valores Limites & Valor "Default" & Unidade \\
\hline Temperatura & $2-55$ & 21 & ${ }^{\circ} \mathrm{C}$ \\
\hline$\overline{\mathrm{OD}}$ & $0-15$ & 0 & $\mathrm{mg} / \mathrm{L}$ \\
\hline$\overline{\mathrm{DBO}}$ & $0-1000$ & 0 & $\mathrm{mg} / \mathrm{L}$ \\
\hline Conservativo 1 & $0-$ & 0 & $\mathrm{mg} / \mathrm{L}$ \\
\hline Conservativo 2 & $0-$ & 0 & $\mathrm{mg} / \mathrm{L}$ \\
\hline Conservativo 3 & $0-$ & 0 & $\mathrm{mg} / \mathrm{L}$ \\
\hline Não-Conservativo & $0-$ & 0 & $\mathrm{mg} / \mathrm{L}$ \\
\hline Coliforme Fecal & $0-$ & 0 & Número/100 mL \\
\hline Nitrogênio Orgânico & $0-$ & 0 & $\mathrm{mg} / \mathrm{L}$ \\
\hline Amônia & $0-$ & 0 & $\mathrm{mg} / \mathrm{L}$ \\
\hline Nitrito & $0-$ & 0 & $\mathrm{mg} / \mathrm{L}$ \\
\hline Nitrato & $0-$ & 0 & $\mathrm{mg} / \mathrm{L}$ \\
\hline Fósforo Orgânico & $0-$ & 0 & $\mathrm{mg} / \mathrm{L}$ \\
\hline Fósforo Dissolvido & $0-$ & 0 & $\mathrm{mg} / \mathrm{L}$ \\
\hline
\end{tabular}


A Tabela 5.4 apresenta dados de parâmetros e variáveis, para as grades: 'Condição Inicial do Rio', 'Dados de Cabeceira', 'Fluxo Incremental' e 'Carga Pontual e Captação’.

O Formulário 5 (Dados de Cabeceira e Fluxo Incremental) apresenta as grades 'Dados de Cabeceira' e 'Fluxo Incremental'. (Figura 5.6)

Nas grades do Formulário 5, exceto para os dados de vazão, os dados de entrada são disponibilizados de acordo com as opções do usuário no processo de escolha das variáveis de qualidade da água a serem simuladas. Os dados do formulário são: Vazão, Temperatura, OD, DBO, Conservativo 1, Conservativo 2, Conservativo 3, NãoConservativo, Coliforme fecal, Nitrogênio Orgânico, Amônia, Nitrito, Nitrato, Fósforo orgânico e Fósforo dissolvido. Esses dados devem ser inseridos para cada cenário simulado e posteriormente validados. (Ver Tabela 5.4 e Figura 5.6)

O Formulário 6 (Coeficientes e, Carga Pontual e Captação) apresenta as grades 'Coeficientes (N, P, Coliforme, Não-Conservativo) e 'Carga Pontual e Captação'. (Ver Figura 5.7)

$\mathrm{Na}$ grade 'Coeficientes (N, P, Coliforme, Não-Conservativo)', insere-se dados de coeficientes, sendo estes: Hidrólise do Nitrogênio Orgânico, Sedimentação do Nitrogênio Orgânico, Oxidação da Amônia, Liberação da Amônia do Sedimento, Oxidação do Nitrito, Decaimento do Fósforo Orgânico, Sedimentação do Fósforo Orgânico, Liberação do Fósforo Dissolvido do Sedimento, Decaimento do Coliforme, Decaimento do Não-Conservativo, Sedimentação do Não-Conservativo e Liberação do Não-Conservativo do Sedimento. Estes dados devem ser inseridos para cada cenário simulado e posteriormente validados. (Ver Tabela 5.5)

Na grade 'Carga Pontual e Captação', os dados de Vazão e Nome são sempre disponibilizados para o usuário. Os dados de percentagem de tratamento são disponibilizados caso o ponto seja identificado como Ponto de Lançamento. Para os pontos identificados como Ponto de Captação, não são disponibilizados os dados de entrada das variáveis, e os dados de vazão devem de ser inseridos como dados negativos. (Ver Tabela 5.4) 
Tabela 5.5 - Coeficientes para a série de nitrogênio e fósforo, coliforme fecal e nãoconservativo

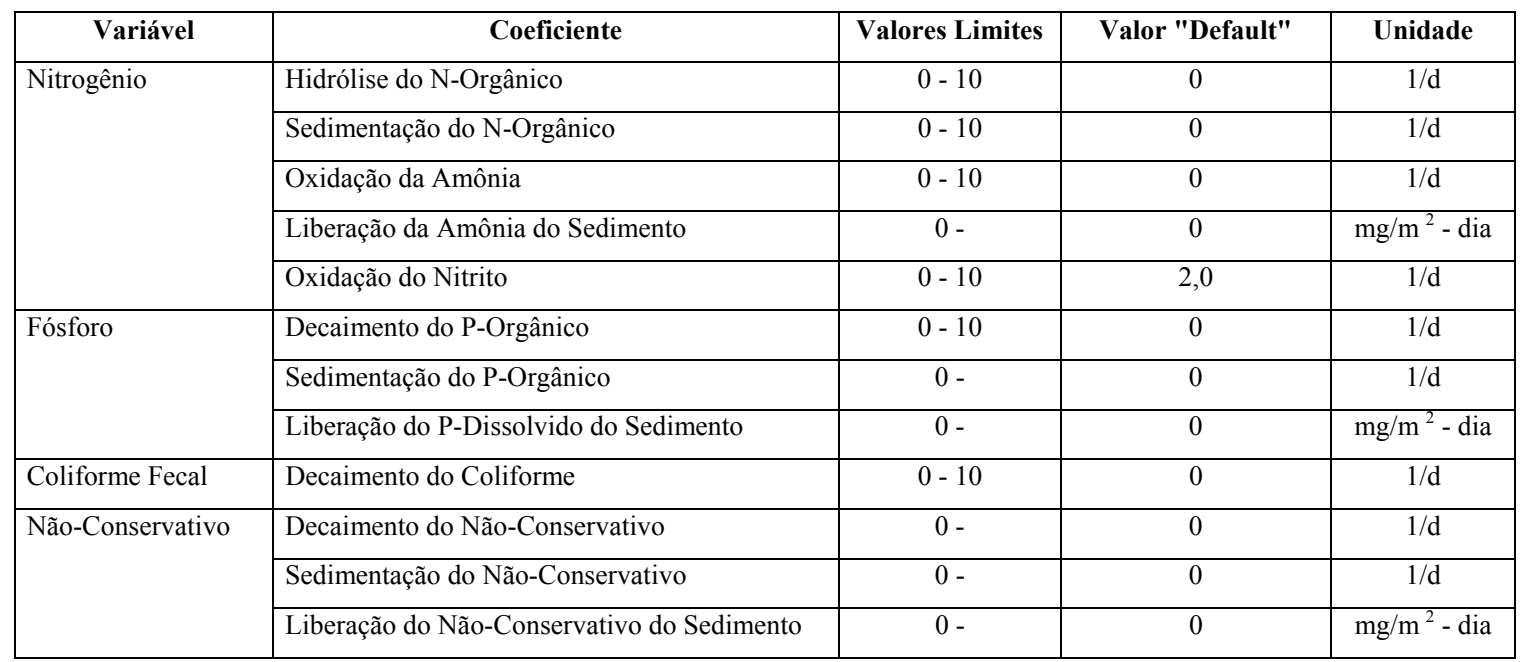

Fonte: Adaptado de BROWN e BARNWELL (1987)

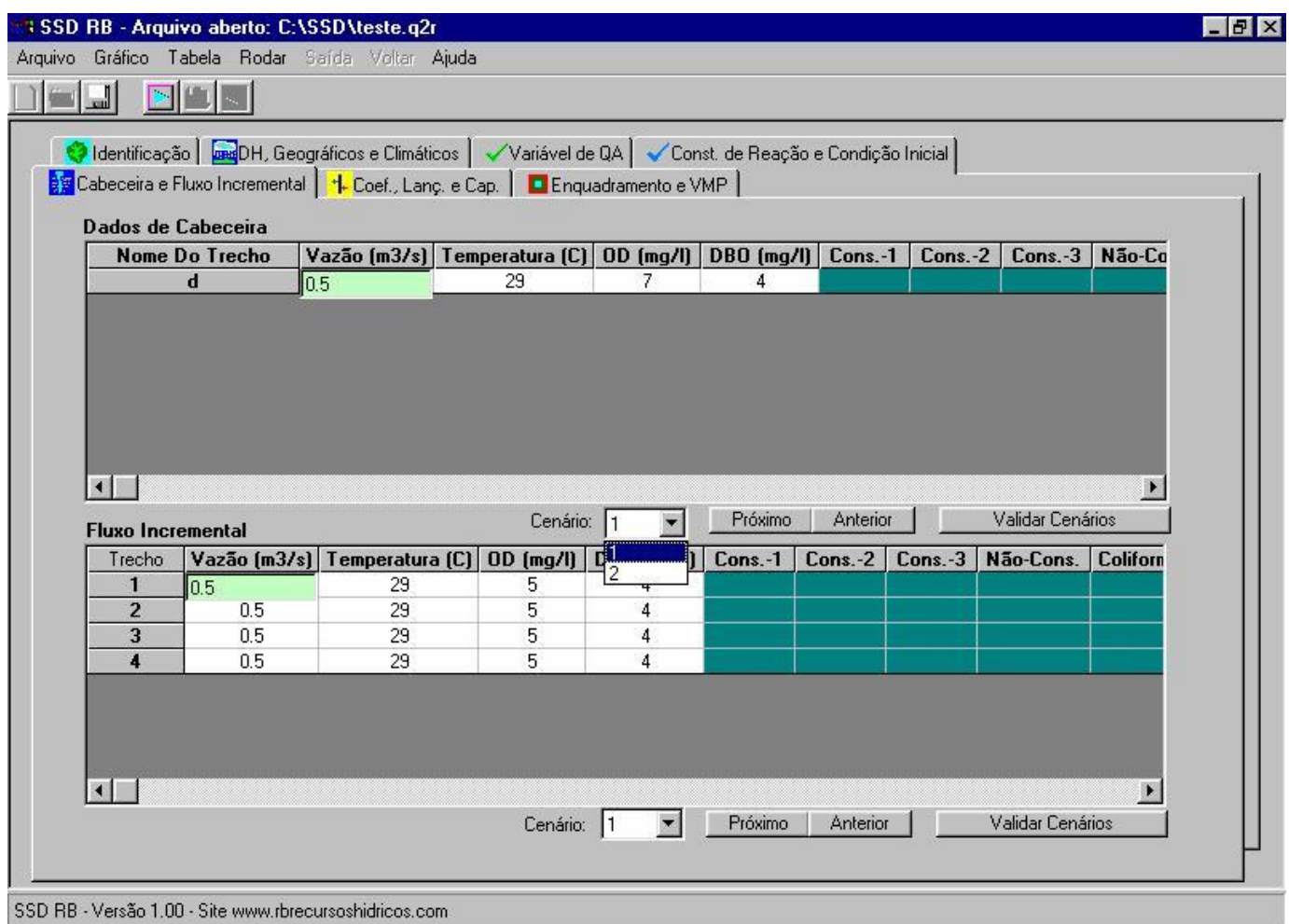

Figura 5.6 - Formulário de Dados de Cabeceira e Fluxo Incremental 


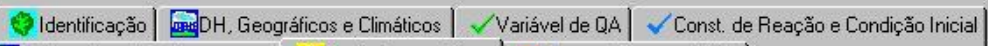

E Cabeceira e Fluxo Incremental + Coef., Lanç. e Cap. | IEnquadramento e VMP |

Coeficientes (N, P. Coliforme, Nāo-Conservativo]

\begin{tabular}{|c|c|c|c|c|}
\hline Trecho & Coef. Hidrólise N-Org [1/d) & Coef. Sed. N-0rg [1/d) & Coef. Oxid. NH3 [1/d) & Taxa Lib. NH3 do Sed. [mg/mí \\
\hline
\end{tabular}

\begin{tabular}{|c|c|c|c|c|}
\hline 1 & 0.2 & 0.2 & 0.3 \\
\hline 2 & 0.2 & 0.2 & 0.3 \\
\hline 3 & 0.2 & 0.2 & 0.3 \\
\hline 4 & & 0.2 & 0.3 \\
\hline
\end{tabular}

\begin{tabular}{l|l|}
\hline 0.3 & 0.1 \\
0.3 & 0.1 \\
\hline 0.3 & 0.1 \\
\hline
\end{tabular}

$1 \square$ $0.2=0.2$

Carga Pontual e Captação

\begin{tabular}{|c|c|c|c|}
\hline Trecho & N. Elemento & Tipo & \\
\hline 2 & 4 & Captação & Cap1 \\
\hline 2 & 11 & Lançamento & \\
\hline 3 & 7 & Lançamento & \\
\hline 3 & 19 & Captação & \\
\hline
\end{tabular}
Nor 1 Lan1 Lan2

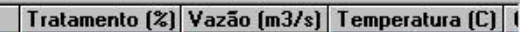

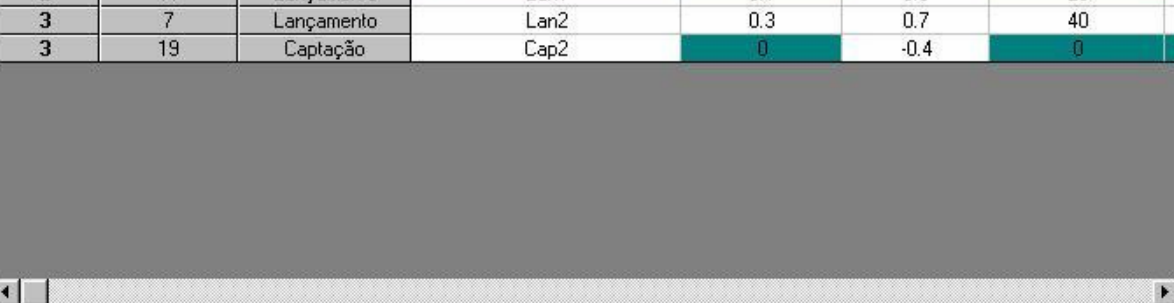

$1 \square$

Figura 5.7 - Formulário Coeficientes e Carga Pontual e Captação

i SSD RB - Arquivo aberto: C.ISSDYteste.q2r

Identificação| [äm

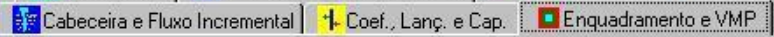

Enquadramento

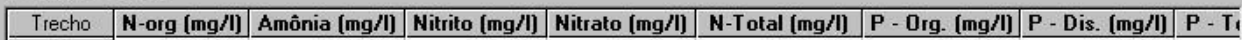

\begin{tabular}{|l|l|l|l|l|l|l|l|}
\hline $\mathbf{1}$ & 4 & 3 & 1 & 2 & 10 & 0.3 & 0.2 \\
\hline $\mathbf{2}$ & 4 & 3 & 1 & 2 & 10 & 0.3 & 0.2 \\
\hline $\mathbf{3}$ & 4 & 3 & 1 & 2 & 10 & 0.3 & 0.2 \\
\hline $\mathbf{4}$ & 4 & 3 & 1 & 2 & 10 & 0.3 & 0.2 \\
\hline
\end{tabular}

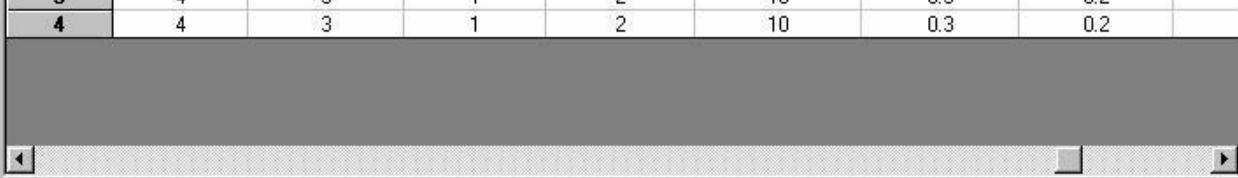

Valor Máximo Permissível para Diluiçāo Valor do Enquadramento

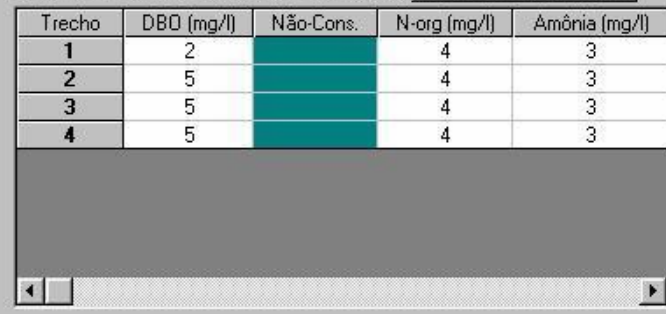

Custo Unitário da Vazẫo de Diluiçẫo R\$ $\longdiv { 0 . 0 2 } \mathrm { M } 3$

Custo Unitário da Vazāo Captada R\$ $\longdiv { 0 . 0 1 }$ M3

SSD RB - Versão 1.00 - Site wwww.rbrecursoshidricos.com

Figura 5.8 - Formulário de Enquadramento 
No Formulário 7 (Enquadramento e VMP), inserem-se: os valores dos padrões associados às Classes de Uso do corpo hídrico simulado; o Valor Máximo Permissível do poluente no corpo hídrico que pode ter os mesmos valores dos padrões de enquadramento ou ser resultante de uma política de recuperação da qualidade da água da bacia hidrográfica em estudo; os custos unitários de captação e lançamento. (Ver Figura 5.8)

Após os dados de entrada terem sido inseridos e validados, o SSD RB passa a estar pronto para ser rodado. Para rodar o modelo, clique no botão 'Rodar', aparecerá uma caixa de texto informando se a simulação foi bem sucedida. Clicar no botão 'OK' .

Os dados de saída são disponibilizados no formato de tabelas e gráficos, num total de 12 formulários.

Após o usuário ter rodado o modelo, sem precisar rodar novamente o mesmo, os dados de saída podem ser visualizados clicando-se apenas no botão 'Saída'.

\subsubsection{Dados de saída do SSD RB}

Os dados de saída do SSD RB são apresentados em 12 formulários. Oito deles foram criados para tratamento e saída gráfica dos dados do modelo QUAL2E (Ver Tabela 5.6), assim como quatro formulários foram criados para tratamentos dos dados liberados pelo modelo RM1. (Ver Tabela 5.9)

Os dados dos formulários de saída podem ser transportados para o Word e para o Excel.

Para transportar os dados dos gráficos, clique no menu 'Gráfico' e, posteriormente, em 'Copiar'. No Word ou no Excel, clique no menu 'Editar' e posteriormente em 'Colar'. Para copiar apenas a figura, no menu 'Editar' do Word ou Excel, clique na opção 'Colar Especial' e posteriormente em 'Bitmap'. Para copiar o gráfico ou seus dados não é preciso clicar na figura. 
Para transportar os dados das planilhas, clique na planilha desejada e, posteriormente, no menu 'Tabela' e selecione a opção 'Copiar'. No Word ou no Excel, clique no menu 'Editar' e, posteriormente, em 'Colar'.

Tabela 5.6 - Saída do SSD RB para os dados liberados pelo modelo QUAL2E

\begin{tabular}{|c|c|c|}
\hline Formulário & Nome & Dados \\
\hline 1 & $\begin{array}{l}\text { Q2E-QA } \\
\text { (Tabela) }\end{array}$ & $\begin{array}{l}\text { - Concentrações das variáveis simuladas, para cada trecho e } \\
\text { elemento, ao longo do corpo receptor. (Ver Tabela 5.7) }\end{array}$ \\
\hline 2 & $\begin{array}{l}\text { Q2E-QA } \\
\text { (Gráfico) }\end{array}$ & $\begin{array}{l}\text { - Concentrações das variáveis simuladas no formato gráfico. } \\
\text { Oferece a possibilidade de combinações das variáveis simuladas, } \\
\text { tanto no rio principal como nos trechos simulados. (Ver Tabela } 5.7 \text { e } \\
\text { Figura 5.9) }\end{array}$ \\
\hline 3 & $\begin{array}{l}\text { Q2E - Coef. Reação } \\
\text { (Tabela) }\end{array}$ & $\begin{array}{l}\text { - Resume todos os dados dos coeficientes de reação utilizados no } \\
\text { processo de entrada de dados. (Ver Tabela 5.7) }\end{array}$ \\
\hline 4 & $\begin{array}{l}\text { Q2E-OD } \\
\text { (Tabela) }\end{array}$ & $\begin{array}{l}\text { - Apresenta o balanço de oxigênio dissolvido, para cada trecho e } \\
\text { elemento. (Ver Tabela 5.8) }\end{array}$ \\
\hline 5 & $\begin{array}{l}\text { Q2E-DH } \\
\text { (Tabela) }\end{array}$ & $\begin{array}{l}\text { - Dados hidráulicos do corpo receptor, para cada trecho e } \\
\text { elemento. (Ver Tabela 5.8) }\end{array}$ \\
\hline 6 & $\begin{array}{l}\text { Q2E-DH } \\
\text { (Gráfico) }\end{array}$ & $\begin{array}{l}\text { - Fornece uma visualização gráfica dos dados hidráulicos. } \\
\text { Oferece a possibilidade de combinações dos dados hidráulicos, tanto } \\
\text { no rio principal como nos trechos simulados. (Ver Tabela } 5.8 \text { e } \\
\text { Figura 5.10) }\end{array}$ \\
\hline 7 & $\begin{array}{l}\text { Q2E - Comp. QA } \\
\text { (Gráfico) }\end{array}$ & $\begin{array}{l}\text { - Concentração das variáveis simuladas no formato gráfico. } \\
\text { Oferece a possibilidade de combinações entre cenários das variáveis } \\
\text { simuladas, tanto no rio principal como nos trechos simulados. (Ver } \\
\text { Figura 5.11) }\end{array}$ \\
\hline 8 & $\begin{array}{l}\text { Q2E - Comp. DH } \\
\text { (Gráfico) }\end{array}$ & $\begin{array}{l}\text { - Dados hidráulicos no formato gráfico. Oferece a possibilidade } \\
\text { de combinações dos dados hidráulicos entre cenários, tanto no rio } \\
\text { principal como nos trechos simulados. (Ver Figura 5.12) }\end{array}$ \\
\hline
\end{tabular}


Tabela 5.7 - Unidade dos dados de saída dos formulários 'Variáveis' e 'Coeficientes de Reação'

\begin{tabular}{|c|c|c|c|c|c|}
\hline \multicolumn{2}{|c|}{ Variáveis } & \multicolumn{2}{|c|}{ Gráfico - Variáveis QA } & \multicolumn{2}{|l|}{ Coef. Reação } \\
\hline \multicolumn{2}{|c|}{ Formulário 1} & \multicolumn{2}{|c|}{ Formulários 2 e 7} & \multicolumn{2}{|l|}{ Formulário 3} \\
\hline Dado & Unidade & Dado & Unidade & Dado & Unidade \\
\hline Trecho & - & Trecho & - & Trecho & - \\
\hline Elemento & - & Elemento & - & Elemento & - \\
\hline Inicio km & $\mathrm{km}$ & - & - & - & - \\
\hline Fim km & $\mathrm{km}$ & - & - & - & - \\
\hline Temperatura & ${ }^{\circ} \mathrm{C}$ & Temperatura & ${ }^{\circ} \mathrm{C}$ & OD de Saturação & $(\mathrm{mg} / \mathrm{L})$ \\
\hline OD & $\mathrm{mg} / \mathrm{L}$ & OD & $\mathrm{mg} / \mathrm{L}$ & Opção de K2 & - \\
\hline $\mathrm{DBO}$ & $\mathrm{mg} / \mathrm{L}$ & $\mathrm{DBO}$ & $\mathrm{mg} / \mathrm{L}$ & Reaeração & $(1 / d)$ \\
\hline Conservativo 1 & $\mathrm{mg} / \mathrm{L}$ & Conservativo 1 & $\mathrm{mg} / \mathrm{L}$ & Dec. da DBO & $(1 / d)$ \\
\hline Conservativo 2 & $\mathrm{mg} / \mathrm{L}$ & Conservativo 2 & $\mathrm{mg} / \mathrm{L}$ & Sed. da DBO & $(1 / d)$ \\
\hline Conservativo 3 & $\mathrm{mg} / \mathrm{L}$ & Conservativo 3 & $\mathrm{mg} / \mathrm{L}$ & Dec. N-Orgânico & $(1 / d)$ \\
\hline Não-Conservativo & $\mathrm{mg} / \mathrm{L}$ & Não-Conservativo & $\mathrm{mg} / \mathrm{L}$ & Sed. N-Orgânico & $(1 / \mathrm{d})$ \\
\hline Coliforme Fecal & Número/100 mL & Coliforme Fecal & Número/100 mL & Dec. NH3 & $(1 / d)$ \\
\hline Nitrogênio Orgânico & $\mathrm{mg} / \mathrm{L}$ & Nitrogênio Orgânico & $\mathrm{mg} / \mathrm{L}$ & Liberação Sed. NH3 & $\left(\mathrm{mg} / \mathrm{m}^{2} \cdot \mathrm{d}\right)$ \\
\hline Amônia & $\mathrm{mg} / \mathrm{L}$ & Amônia & $\mathrm{mg} / \mathrm{L}$ & Dec. NO2 & $(1 / \mathrm{d})$ \\
\hline Nitrito & $\mathrm{mg} / \mathrm{L}$ & Nitrito & $\mathrm{mg} / \mathrm{L}$ & Dec. P-Orgânico & $(1 / d)$ \\
\hline Nitrato & $\mathrm{mg} / \mathrm{L}$ & Nitrato & $\mathrm{mg} / \mathrm{L}$ & Sed. P-Orgânico & $(1 / \mathrm{d})$ \\
\hline Fósforo Orgânico & $\mathrm{mg} / \mathrm{L}$ & Fósforo Orgânico & $\mathrm{mg} / \mathrm{L}$ & Lib. Sed. P-Dissolvido & $\left(\mathrm{mg} / \mathrm{m}^{2} . \mathrm{d}\right)$ \\
\hline Fósforo Dissolvido & $\mathrm{mg} / \mathrm{L}$ & Fósforo Dissolvido & $\mathrm{mg} / \mathrm{L}$ & Dec. Coliforme Fecal & $(1 / \mathrm{d})$ \\
\hline- & - & - & - & Dec. Não-Conservativo & $(1 / \mathrm{d})$ \\
\hline- & - & - & - & Sed. Não-Conservativo & $(1 / \mathrm{d})$ \\
\hline- & - & - & - & Lib. Sed. Não-Conservativo & $\left(\mathrm{mg} / \mathrm{m}^{2} \cdot \mathrm{d}\right)$ \\
\hline
\end{tabular}

Fonte: Adaptado de BROWN e BARNWELL (1987)

Tabela 5.8 - Unidade dos dados de saída dos formulários 'Balanço de OD' e Dados Hidráulicos

\begin{tabular}{|c|c|c|c|c|c|}
\hline \multicolumn{2}{|c|}{ Balanço OD } & \multicolumn{2}{|l|}{ Dados Hidráulicos } & \multicolumn{2}{|c|}{ Gráfico - Dados Hidráulicos } \\
\hline \multicolumn{2}{|c|}{ Formulário 4} & \multicolumn{2}{|l|}{ Formulário 5} & \multicolumn{2}{|c|}{ Formulários 6 e 8} \\
\hline Dado & Unidade & Dado & Unidade & Dado & Unidade \\
\hline Trecho & - & Trecho & - & - & - \\
\hline Elemento & - & Elemento & - & - & - \\
\hline Temperatura & $\left({ }^{\circ} \mathrm{C}\right)$ & Inicio $\mathrm{km}$ & $\mathrm{km}$ & - & - \\
\hline OD Saturação & $(\mathrm{mg} / \mathrm{L})$ & Fim km & $\mathrm{km}$ & - & - \\
\hline OD & $(\mathrm{mg} / \mathrm{L})$ & Vazão & $\left(\mathrm{m}^{3} / \mathrm{s}\right)$ & Vazão & $\left(\mathrm{m}^{3} / \mathrm{s}\right)$ \\
\hline Déficit OD & $(\mathrm{mg} / \mathrm{L})$ & Lançamento ou Captação & $\left(\mathrm{m}^{3} / \mathrm{s}\right)$ & Vazão Incremental & $\left(\mathrm{m}^{3} / \mathrm{s}\right)$ \\
\hline $\begin{array}{l}\text { Fator Inibição da } \\
\text { Nitrificação }\end{array}$ & - & Vazão Incremental & $\left(\mathrm{m}^{3} / \mathrm{s}\right)$ & Vazão Incremental & $\left(\mathrm{m}^{3} / \mathrm{s}\right)$ \\
\hline Função Força & $(\mathrm{mg} / \mathrm{L} . \mathrm{d})$ & Velocidade & $(\mathrm{m} / \mathrm{s})$ & Velocidade & $(\mathrm{m} / \mathrm{s})$ \\
\hline Reaeração & $(\mathrm{mg} / \mathrm{L} . \mathrm{d})$ & Tempo de Percurso & (dia) & - & - \\
\hline Cons. OD DBOc & $(\mathrm{mg} / \mathrm{L} . \mathrm{d})$ & Profundidade & $(\mathrm{m})$ & Profundidade & (m) \\
\hline Cons. OD do Sed. & $(\mathrm{mg} / \mathrm{L} . \mathrm{d})$ & Largura (m) & $(\mathrm{m})$ & Largura (m) & (m) \\
\hline Net P-R & $(\mathrm{mg} / \mathrm{L} . \mathrm{d})$ & Volume & $\left(\mathrm{m}^{3}\right)$ & Volume & $\left(\mathrm{m}^{3}\right)$ \\
\hline Cons. OD Oxid. NH3 & $(\mathrm{mg} / \mathrm{L} . \mathrm{d})$ & Área da Seção Transv. & $\left(\mathrm{m}^{2}\right)$ & Área da Seção Transv. & $\left(\mathrm{m}^{2}\right)$ \\
\hline Cons. OD Oxid. NO2 & $(\mathrm{mg} / \mathrm{L} . \mathrm{d})$ & Coef. Dispersão & $(\mathrm{m} / \mathrm{s})$ & - & - \\
\hline
\end{tabular}

Fonte: Adaptado de BROWN e BARNWELL (1987) 
国RM1 - Vazão de Diluição | 国RM1 - Vazão Liberada | 国RM1 - QD de Captação; Custo | 国RM1 - Custo de QD e QC

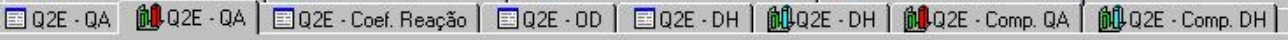

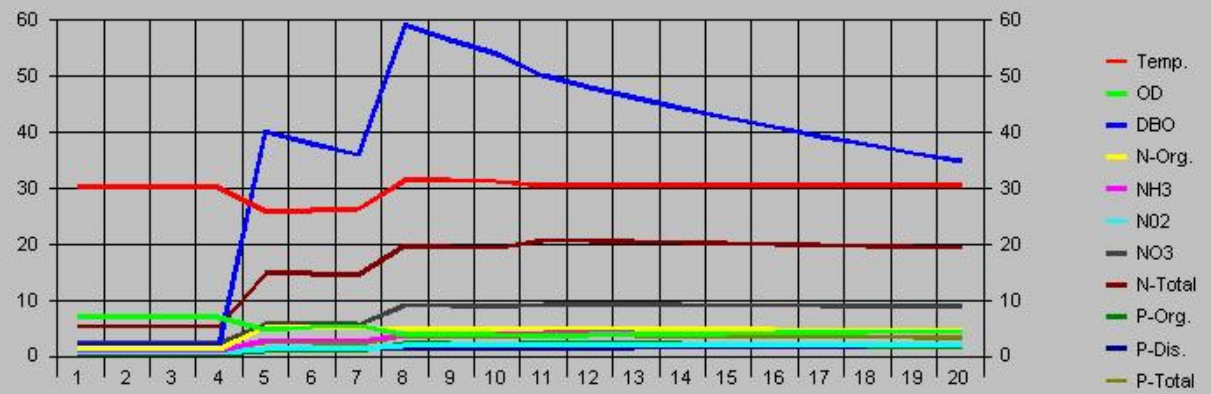

\begin{tabular}{|c|c|c|c|c|c|c|c|c|c|}
\hline $\begin{array}{l}\sqrt{\nabla} \text { Temperatura } \\
\bar{\nabla} \text { Cons } 1\end{array}$ & $\begin{array}{l}\sqrt{\text { C Cons.2 }} \\
\mathbb{\nabla} \text { Cons.3 }\end{array}$ & $\begin{array}{ll}\sqrt{\nabla} & \text { OD } \\
\sqrt{\nabla} & D B O\end{array}$ & $\frac{\sqrt{v}}{\sqrt{v}}$ & $\begin{array}{l}\mathrm{N}-\mathrm{Org} \\
\mathrm{NH} 3\end{array}$ & $\begin{array}{ll}\sqrt{\nabla} & N 02 \\
\sqrt{V} & N 03\end{array}$ & $\begin{array}{ll}\sqrt{V} & \text { N-Total } \\
\sqrt{V} & \text { P-Org. }\end{array}$ & $\begin{array}{l}\sqrt{\nabla} \text { P-Dis. } \\
\sqrt{\nabla} \text { P-Total }\end{array}$ & & $\begin{array}{l}\text { olfiforme } \\
\text { Conservativg }\end{array}$ \\
\hline - Tipo de Gráfico & \multicolumn{9}{|c|}{-Aparencia do Gráfico 3D } \\
\hline C 3D Barra & C 3D Linha & \multirow{2}{*}{\multicolumn{2}{|c|}{$\begin{array}{l}C \text { 3D Área } \\
C \text { 2D Area }\end{array}$}} & \multirow{2}{*}{\multicolumn{2}{|c|}{$\begin{array}{l}\text { Potaçầ: } \\
11\end{array}$}} & \multirow{2}{*}{ Elevação: } & \multicolumn{2}{|c|}{ Iluminação: } & \\
\hline ( 20 barra & c $2 \mathrm{D}$ Linha & & & & & & 4 & r & IV Lininas \\
\hline
\end{tabular}

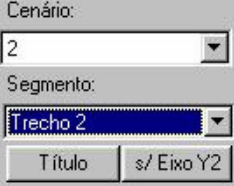

SSD RB - Versão $1.00 \cdot$ Site www.rbrecursoshidricos.com

Figura 5.9 - Formulário com gráfico de qualidade da água

4 SSD RB - Arquivo aberto: C:ISSD Yteste.q2i - [SSD RB - Saída]

Arquivo Gráfico Tabela Fiodar Sajida Voltar Ajuda

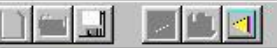

国RM1 - Vazão de Diluição|国RM1 - Vazão Liberada 国RM1 - QD de Captação; Custo | 国RM1 - Custo de QD e QC

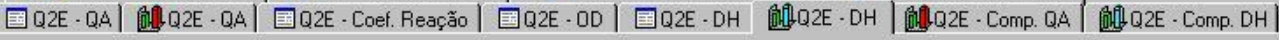

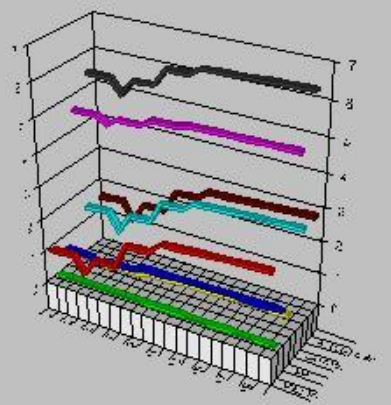

$$
\begin{aligned}
& \text { - Vazẫo } \\
& \text { - Vazẫo Incr. } \\
& \text { - Vel. } \\
& \text { - Prot. } \\
& \text { - Comp. } \\
& \text { Vol. } \\
& \text { - Área-Leito } \\
& \text { - Área-ST }
\end{aligned}
$$

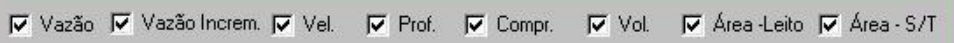
Tipo de Gráfico

C 3D Barra C 3D Linhä C 3D Area

C $2 \mathrm{D}$ Barra $C 2 \mathrm{D}$ Linha $2 \mathrm{DA}$ rea

$$
\begin{aligned}
& \text { Aparência do Gráfico 3D } \\
& \text { Rotação: Elevação: }
\end{aligned}
$$

Cenário:

2

Segmento:

Trecho 2 s/Eixo Y2 Título 


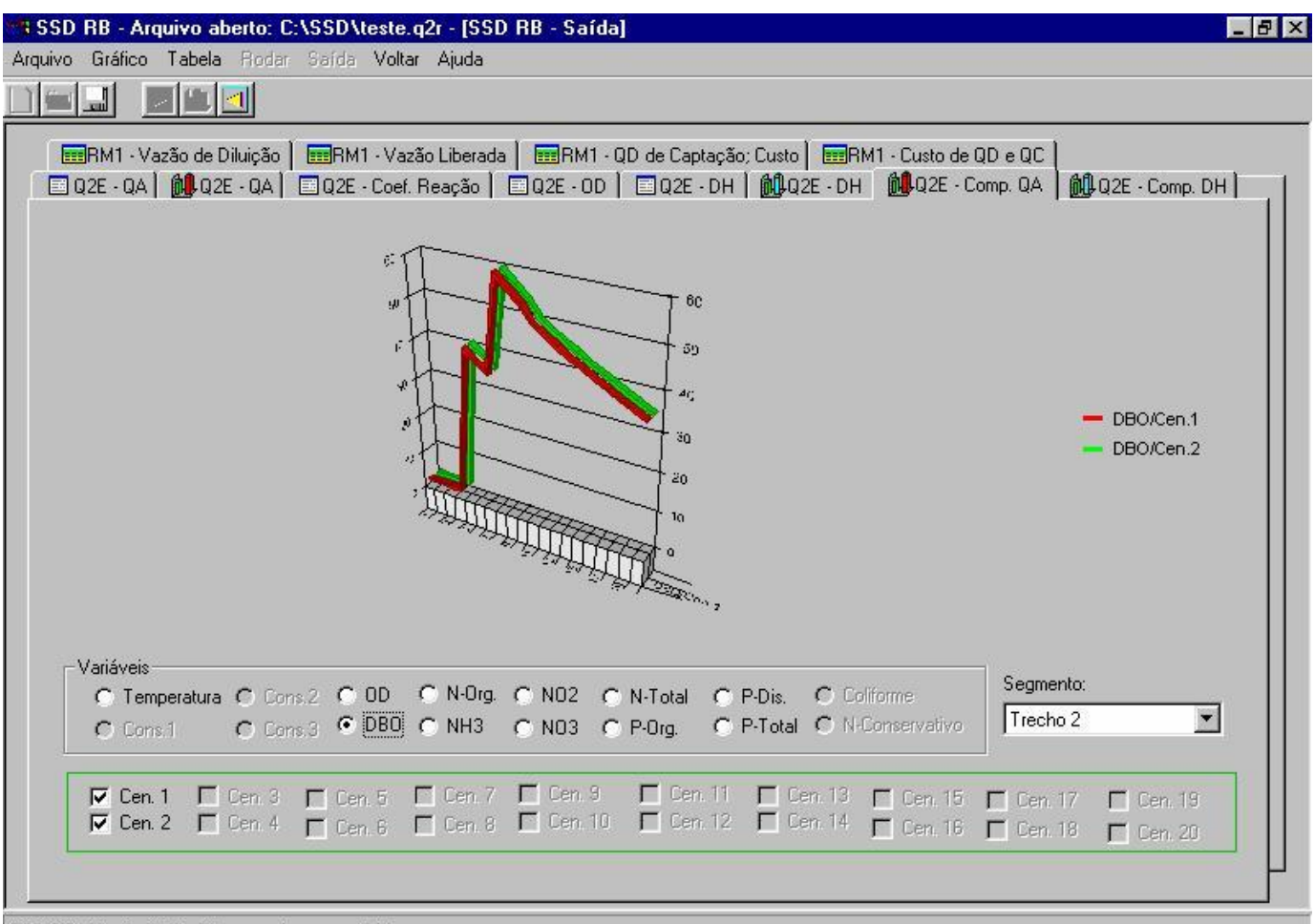

SSD RB - Versão 1.00 - Site wwww.tbrecursoshidricos.com

Figura 5.11 - Formulário com gráfico de dados de qualidade da água entre cenários

SSD RB - Arquivo aberto: C:ISSDYteste.q2r - [SSD RB - Saída]

Arquivo Gráfico Tabela Fiodar Sáda Voltar Ajuda

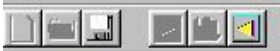

国RM1 - Vazão de Diluição | 国RM1 - Vazão Liberada | 国RM1 - QD de Captação; Custo| 国RM1 - Custo de QD e QC |

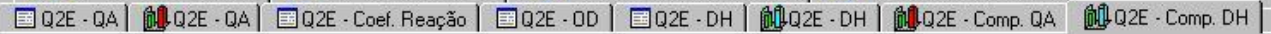

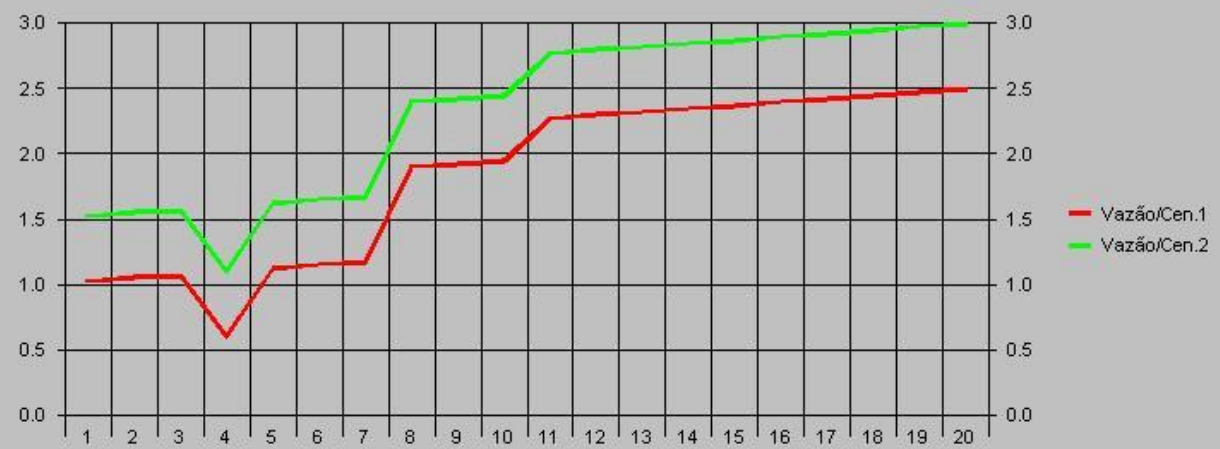

- Variáveis

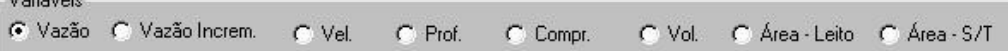

Segmento:

Trecho 2

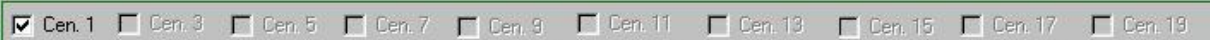

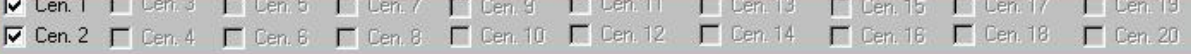

SSD RB - Versão 1.00 - Site wwww.tbrecursoshidricos.com

Figura 5.12 - Formulário com gráfico de dados hidráulicos entre cenários 
Tabela 5.9 - Saída do SSD RB para os dados liberados pelo modelo RM1

\begin{tabular}{|c|c|c|}
\hline Formulário & Nome & Dados \\
\hline 9 & RM1 - Vazão de Diluição & $\begin{array}{l}\text { - Vazão de diluição ao longo do rio, em função do } \\
\text { lançamento e do cenário. } \\
\text { - Vazão de diluição média por lançamento e } \\
\text { poluente, em função do cenário. }\end{array}$ \\
\hline 10 & RM1 - Vazão Liberada & $\begin{array}{l}\text { - Vazão liberada por lançamento, em função do } \\
\text { cenário. } \\
\text { - Vazão liberada média por lançamento, em função } \\
\text { do cenário. } \\
\text { - Vazão liberada para outorgas, em função da } \\
\text { cabeceira e do cenário. }\end{array}$ \\
\hline 11 & RM1 - QD de Captação; Custo & $\begin{array}{l}\text { - Captação - Vazão de diluição da carga de } \\
\text { poluente, em função do cenário e da captação. } \\
\text { - } \text { Captação - Maior vazão de diluição da carga de } \\
\text { poluente, em função do cenário e da captação. } \\
\text { - } \quad \text { Lançamento - Vazão de diluição a pagar por } \\
\text { captação, em função do cenário. } \\
\text { - Rio - Custo médio por lançamento e poluente, em } \\
\text { função do cenário. } \\
\text { Rio - Maior valor de custo por lançamento, em } \\
\text { função do cenário. } \\
\text { Captação - Custo total a pagar por lançamento e } \\
\text { Bônus por captação, em função do cenário. } \\
\text { Captação - Custo total a pagar por lançamento e } \\
\text { Bônus total, em função do cenário. }\end{array}$ \\
\hline 12 & RM1 - Custo de QD e QC & $\begin{array}{l}\text { - Custo médio por lançamento e cenário, } \\
\text { desconsiderando a vazão de diluição de captação. } \\
\text { - Custo médio por lançamento e cenário, } \\
\text { considerando a vazão de diluição de captação. } \\
\text { - Custo de vazão captada, em função do cenário. }\end{array}$ \\
\hline
\end{tabular}

QD - Vazão de diluição; QC - Vazão de captação; Bônus - Valor calculado para a diluição da carga de poluente retida do corpo hídrico através de captação; Vazão liberada por lançamento - representa o quanto de vazão o usuário está deixando de pagar quando levado em consideração o processo de autodepuração do rio; Vazão liberada para outorga - representa a vazão do corpo hídrico disponibilizada para novas outorgas.

As figuras de 5.13 a 5.16 apresentam formulários de saída do SSD RB para os dados liberados pelo modelo RM1. 
SSD RB - Arquivo aberto: C:ISSDVteste.q2r - [SSD RB - Saída]

Arquivo Gráfico Tabela

Voltar Ajuda

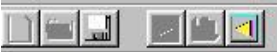

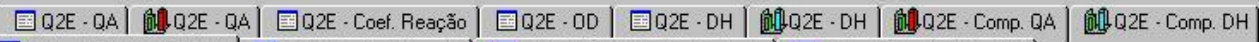
圂RM1 - Vazão de Diluição | 国RM1 - Vazão Liberada | 圂RM1-QD de Caplaçãa; Custo| 圂RM1 - Custo de QD e QC |

Yazão de Diluição ao Longo do Rio

\begin{tabular}{|c|c|c|}
\hline Ordem & Trecho & Elemento \\
\hline 1 & 2 & 5 \\
\hline 2 & 2 & 6 \\
\hline 3 & 2 & 7 \\
\hline 4 & 2 & 8 \\
\hline 5 & 2 & 9 \\
\hline 6 & 2 & 10 \\
\hline 7 & 2 & 11 \\
\hline 8 & 2 & 12 \\
\hline 1 & & \\
\hline
\end{tabular}

\begin{tabular}{|l|l|l|l|l|l|l|l|l|l|l|l|l|}
\hline 76.00 & 75.00 & 8.702 & 1.238 & 0.833 & 0.997 & 2.492 & 1.342 & 0.317 & 0.510 & 0.394 & - \\
\hline 75.00 & 74.00 & 8.448 & 1.233 & 0.836 & 1.012 & 2.513 & 1.347 & 0.303 & 0.518 & 0.393 &.- \\
\hline 74.00 & 73.00 & 8.124 & 1.217 & 0.831 & 1.018 & 2.504 & 1.338 & 0.289 & 0.532 & 0.384 &.- \\
\hline 73.00 & 72.00 & 7.927 & 1.211 & 0.836 & 1.026 & 2.517 & 1.341 & 0.000 & 0.541 & 0.384 & - \\
\hline 72.00 & 71.00 & 7.645 & 1.200 & 0.832 & 1.037 & 2.515 & 1.338 & 0.000 & 0.547 & 0.376 & - \\
\hline 71.00 & 70.00 & 7.410 & 1.189 & 0.832 & 1.072 & 2.525 & 1.340 & 0.000 & 0.556 & 0.374 &.- \\
\hline 70.00 & 69.00 & 7.178 & 1.180 & 0.825 & 1.067 & 2.531 & 1.335 & 0.000 & 0.579 & 0.372 &.- \\
\hline 69.00 & 68.00 & 6.978 & 1.179 & 0.836 & 1.104 & 2.542 & 1.336 & 0.000 & 0.586 & 0.368 &.- \\
\hline
\end{tabular}

Vazẩo de Diluição Média por Lançamento e Poluente $1 \mathrm{~m} 3 / \mathrm{s}]$

Lançamento: $1 \pm$ Cenário: 1

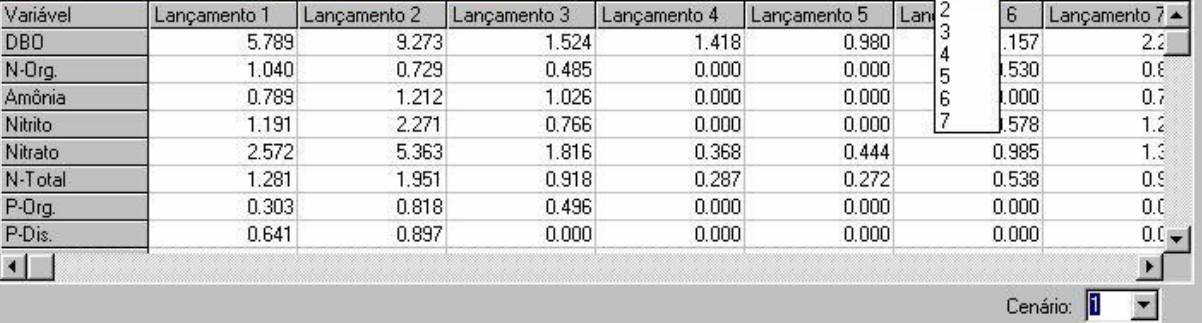

SSD RB - Versão 1.00 - Site www.rbrecursoshidricos.com

Figura 5.13 - Formulário de saída do SSD RB ‘RM1 - Vazão de Diluição’

SSD RB - Arquivo aberto: C:ISSDYteste.q2r - [SSD RB - Saída]

Arquivo Gráfico Tabela

Voltar Aiuda

D国国国国

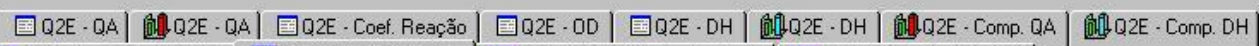

圂RM1 - Vazã̃o de Diluição 北RM1 - Vazão Liberada | 国RM1 - QD de Captação; Custo | 国RM1 - Custo de QD e QC |

Vazão Liberada por Lançamento

\begin{tabular}{|c|c|c|c|c|c|c|c|}
\hline Ordem & Trecho & Elemento & Inicio Km & Fim Km & DBO & N-Org. & NH3 \\
\hline 1 & 2 & 5 & 76.00 & 75.00 & 0.00 & 0.000 & 0.000 \\
\hline 2 & 2 & 6 & 75.00 & 74.00 & 0.25 & 0.004 & -0.003 \\
\hline 3 & 2 & 7 & 74.00 & 73.00 & 0.58 & 0.021 & 0.002 \\
\hline 4 & 2 & 8 & 73.00 & 72.00 & 0.78 & 0.026 & -0.003 \\
\hline 5 & 2 & 9 & 72.00 & 71.00 & 1.06 & 0.038 & 0.001 \\
\hline 6 & 2 & 10 & 71.00 & 70.00 & 1.29 & 0.048 & 0.001 \\
\hline 7 & 2 & 11 & 70.00 & 69.00 & 1.52 & 0.057 & 0.008 \\
\hline 8 & 2 & 12 & 69.00 & 68.00 & 1.72 & 0.059 & -0.003 \\
\hline 1
\end{tabular}

Vazẩo Liberada Média por Lançamento

\begin{tabular}{|c|c|c|c|c|c|c|c|c|c|c|c|c|c|c|c|}
\hline & & & & .anç.: $\sqrt{1}$ & $\nabla c$ & lário: $\sqrt{1}$ & $\nabla$ & {$[\mathrm{m} 3 / \mathrm{s}$} & & & & io: 11 & $\nabla$ & & \\
\hline Ordem & Trecho & Elemento & Inicio Km & Fim Km & DBO & $\mathrm{N}-\mathrm{Org}$. & $\mathrm{NH} 3$ & Nitrito & Nitrato & N-Total & P-Org. & P. 2 & otal & Não-Cons. & $\triangle$ \\
\hline 1 & 1 & 1 & 100.00 & 99.00 & -0.471 & 0.385 & 0.348 & 0.016 & -0.005 & 0.259 & 0.435 & 0.385 & 0.415 &. & \\
\hline 2 & 1 & 2 & 99.00 & 98.00 & -0.451 & 0.403 & 0.369 & 0.028 & -0.008 & 0.273 & 0.462 & 0.402 & 0.439 & .. & \\
\hline 3 & 1 & 3 & 98.00 & 97.00 & -0.425 & 0.415 & 0.384 & 0.040 & -0.011 & 0.282 & 0.481 & 0.413 & 0.454 & .. & \\
\hline 4 & 1 & 4 & 97.00 & 96.00 & -0.405 & 0.432 & 0.404 & 0.054 & -0.018 & 0.296 & 0.508 & 0.429 & 0.478 & .. & \\
\hline 5 & 1 & 5 & 96.00 & 95.00 & -0.381 & 0.443 & 0.420 & 0.068 & -0.022 & 0.306 & 0.527 & 0.440 & 0.492 & .. & \\
\hline 6 & 1 & 6 & 95.00 & 94.00 & -0.361 & 0.461 & 0.440 & 0.078 & -0.026 & 0.320 & 0.555 & 0.455 & 0.516 & .. & \\
\hline 7 & 1 & 7 & 94.00 & 93.00 & -0.335 & 0.472 & 0.456 & 0.094 & -0.030 & 0.329 & 0.574 & 0.466 & 0.531 & .. & \\
\hline 8 & 1 & 8 & 93.00 & 92.00 & -0.319 & 0.490 & 0.476 & 0.105 & -0.035 & 0.343 & 0.602 & 0.483 & 0.554 & .. & \\
\hline 9 & 1 & 9 & 92.00 & 91.00 & -0.295 & 0.502 & 0.490 & 0.122 & -0.040 & 0.352 & 0.622 & 0.493 & 0.570 & .. & $\nabla$ \\
\hline
\end{tabular}
Cabeceira: 17 Cenário: 17

SSD RB - Versão 1.00 - Site www.rbrecursoshidricos.com

Figura 5.14 - Formulário de saída do SSD RB 'RM1 - Vazão Liberada' 


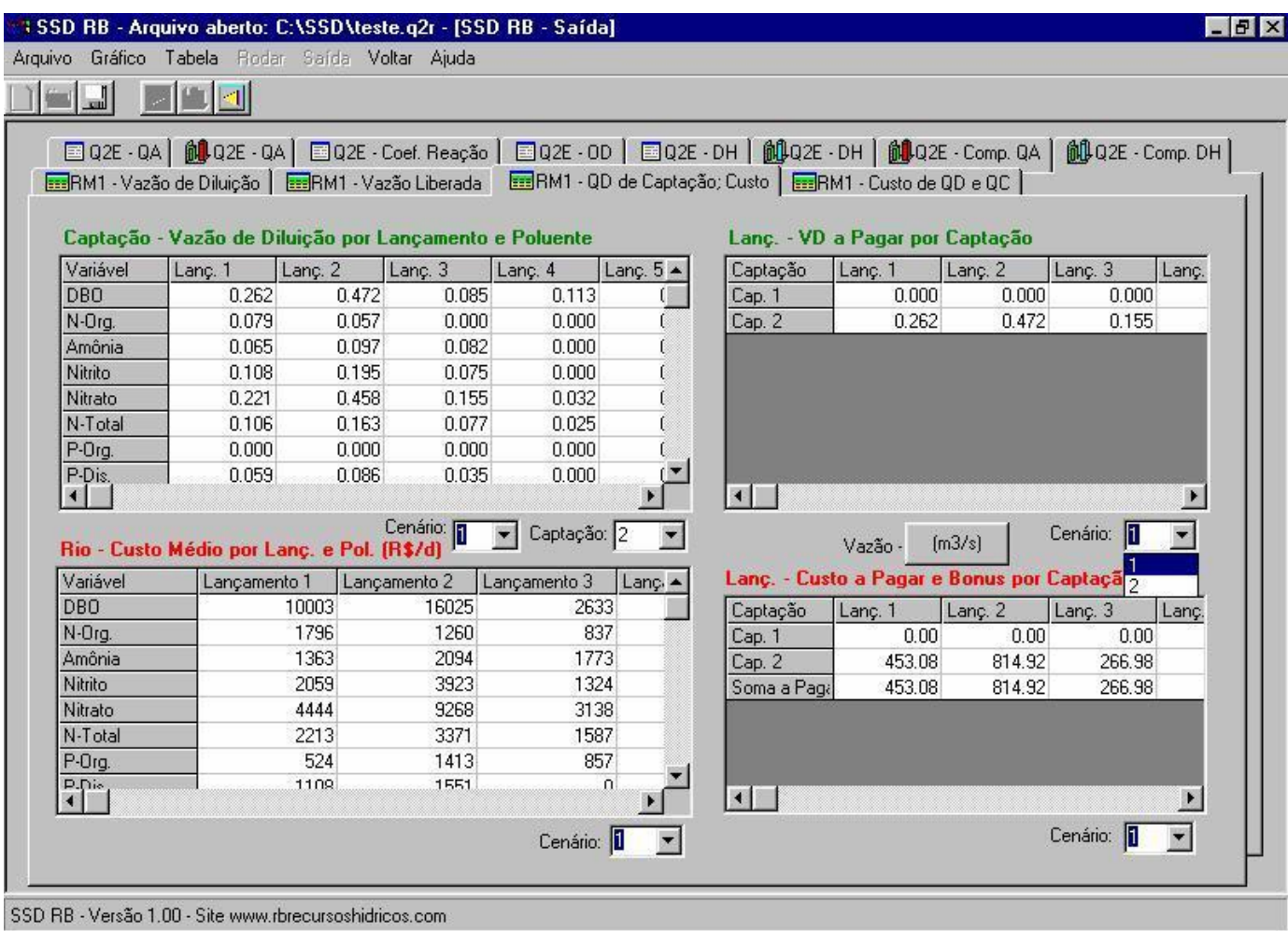

Figura 5.15 - Formulário de saída do SSD RB ‘RM1 - QD de Captação; Custo’

? SSD RB - Arquivo aberto: C:ISSDVteste.q2r - [SSD RB - Saída]

\section{Arquivo Gráfico Tabela Flodar Saída Voltar Ajuda}

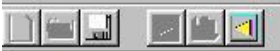

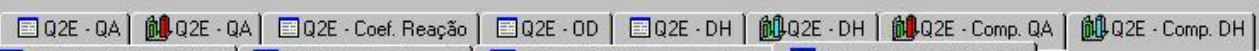

国RM1 - Vazão de Diluição| 国RM1 - Vazão Liberada | 圂RM1 -QD de Captaçãa: Custo 国RM1 - Custo de QD e QC |

\begin{tabular}{|c|c|c|}
\hline Lançamento & Cen. 1 & Cen. 2 \\
\hline Lanç. 1 & 10003.48 & 10003.48 \\
\hline Lanç. 2 & 16024.54 & 16024.41 \\
\hline Lanç. 3 & 3138.35 & 3138.35 \\
\hline Lanç. 4 & 2450.69 & 2450.52 \\
\hline Lanç. 5 & 1693.65 & 1693.87 \\
\hline Lanç. 6 & 1998.59 & 1998.59 \\
\hline Lanç. 7 & 3893.46 & 3893.01 \\
\hline
\end{tabular}

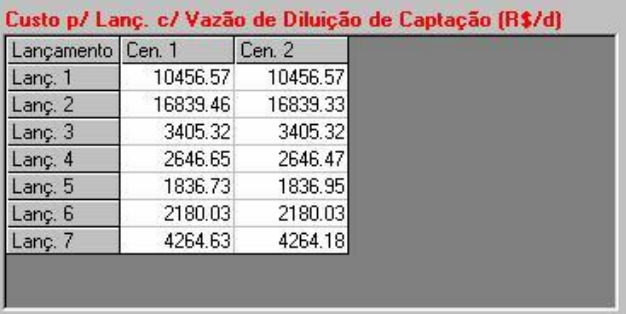

Custo de Vazăo Captada [Rঙ/d]

Custo de Vazẫo Captada por Cenário [R\$/d)

\begin{tabular}{|c|c|c|c|c|}
\hline Captação & Vazão (m3/s) & Custo (R\$) & Bonus [R\$) & Custo-Bonus [R\$) \\
\hline
\end{tabular}

\begin{tabular}{|c|c|c|c|c|}
\hline Cap. 1 & 0.500 & 432.00 & 0.00 & 432.00 \\
\hline Cap. 2 & 0.300 & 259.20 & 2426.63 & -2167.43 \\
\hline
\end{tabular}

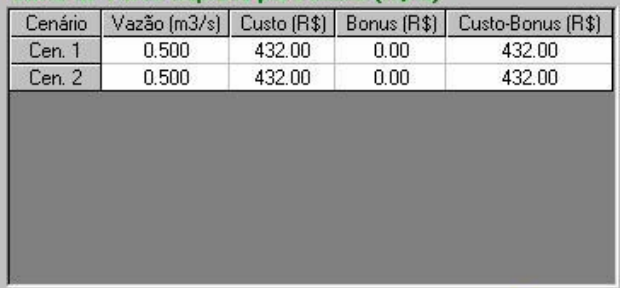

Cenắio: 1

Captação: $\mathbf{1} \quad \mathbf{-}$

SSD RB - Versão 1.00 - Site wwww. brecursoshidricos.com

Figura 5.16 - Formulário de saída do SSD RB 'RM1 - Custo de QD e QC' 


\subsection{Aplicação do SSD RB na bacia do rio Jundiaí}

O SSD RB foi aplicado na bacia do rio Jundiaí, afluente do rio Tietê, localizado no Estado de São Paulo.

\subsubsection{Cenários de aplicação do SSD RB na bacia do rio Jundiaí}

A aplicação do SSD RB foi realizada através de três cenários. A Tabela 5.10 apresenta um resumo dos cenários simulados e seus critérios e objetivos.

Tabela 5.10 - Cenários de aplicação do SSD RB na bacia o rio Jundiaí

\begin{tabular}{|c|c|c|}
\hline Cen. & Critérios & Objetivos \\
\hline 1 & $\begin{array}{l}\text { - Fixar a vazão de referência para o } \\
\text { regime } Q_{95} \text {. } \\
\text { - } \text { Fixar os valores unitários de } \\
\text { cobrança da QD em } \mathrm{R} \$ 0,01 / \mathrm{m}^{3} \text { e } \\
\text { da QC em } \mathrm{R} \$ 0,008 / \mathrm{m}^{3} . \\
\text { - Variar o enquadramento para as } \\
\text { Classes } 2 \text { e } 4 \text { para a DBO. }\end{array}$ & \begin{tabular}{|} 
Verificar a interferência da Classe de Uso de um \\
rio em: \\
- Vazão de diluição ao longo do rio; \\
- Vazão de diluição da carga de poluente \\
$\quad$ retirada através de captação; \\
- Vazão liberada para novas outorgas; \\
- Vazão liberada por lançamento; \\
- Custo de lançamento e captação.
\end{tabular} \\
\hline 2 & 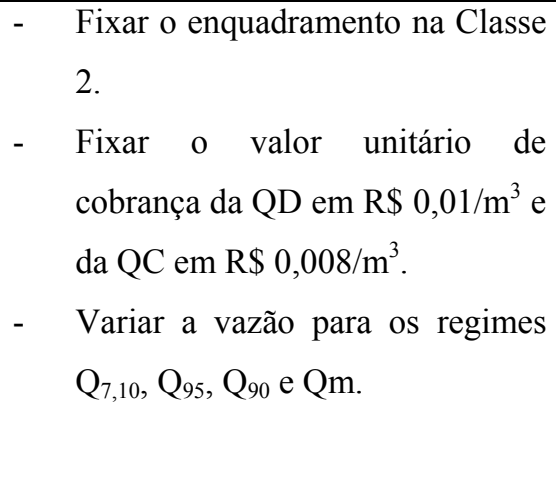 & $\begin{array}{l}\text { Verificar a interferência do regime de vazão } \\
\text { adotado para o corpo hídrico em: } \\
\text { - Vazão de diluição ao longo do rio; } \\
\text { - Vazão de diluição da carga de poluente } \\
\quad \text { retirada através de captação; } \\
\text { - Vazão liberada para novas outorgas; } \\
\text { - Vazão liberada por lançamento; } \\
\text { - Custo de lançamento e captação. }\end{array}$ \\
\hline 3 & $\begin{array}{l}\text { - } \text { Fixar o regime de vazão em } \mathrm{Q}_{95} . \\
\text { - } \quad \text { Fixar o enquadramento na Classe } \\
2 . \\
\text { - } \quad \text { Variar valores unitários de } \\
\text { cobrança em } \mathrm{R} \$ \mathrm{~m}^{3} \text { : } \\
\text { a) } \mathrm{QD}=0,01 \text { e } \mathrm{QC}=0,008 ; \\
\text { b) } \mathrm{QD}=0,0005 \text { e } \mathrm{QC}=0,01 ; \\
\text { c) } \mathrm{QD}=0,02 \text { e } \mathrm{QC}=0,02 .\end{array}$ & $\begin{array}{l}\text { Verificar a interferência dos custos unitários de } \\
\text { captação e de diluição na cobrança pelo uso da } \\
\text { água. }\end{array}$ \\
\hline
\end{tabular}

QD - Vazão de diluição; QC - Vazão de captação 
Os três cenários simulados foram realizados com o objetivo de se verificar isoladamente a interferência da Classe de Uso, do regime de vazão e dos custos unitários adotados, nos processos de outorga e cobrança pelo uso da água. Mas ressalte-se que o SSD RB permite a realização de diversos cenários, combinados entre:

- Dados Hidráulicos;

- $\quad$ Dados de Cabeceira;

- Dados de Condição Inicial do Rio;

- Poluição Difusa;

- Parâmetros e Coeficientes;

- Custos Unitários;

- $\quad$ Classe de Uso.

A combinação entre cenários, através do SSD RB, é possível porque em um único arquivo de entrada de dados do sistema, para cada cenário, é inserido um conjunto de dados pertinente ao mesmo. Quando o usuário clica no botão "rodar" do sistema, os cálculos realizados pelos modelos RM1 e QUAL2E são realizados distintamente para cada cenário, possibilitando, na saída do sistema, uma análise comparativa entre os resultados obtidos para cada cenário simulado, permitindo assim, um maior controle da relação causa x efeito dos fatores envolvidos na gestão de uma bacia hidrográfica.

A seguir, é apresentada uma descrição mais detalhada dos cenários simulados e dos resultados obtidos. Foram simulados os Lançamentos de 1 a 18 (L1 a L18) apresentados na Tabela 4.9, na pág. 86 .

Os lançamentos que apresentam valores nulos de vazão de diluição são devidos à baixa carga lançada no corpo hídrico, em função da vazão do rio e da própria sensibilidade do modelo que são de duas casas decimais para as variáveis simuladas.

\section{$\underline{1^{o} . \text { Cenário }}$}

No Cenário 1, a vazão adotada foi a Q95, assim como as Classes de Uso para os lançamentos simulados foram as Classes 2 e 4, conferindo ao corpo hídrico valores 
máximos permissíveis de DBO de $5 \mathrm{mg} / \mathrm{L}$ e $10 \mathrm{mg} / \mathrm{L}$, respectivamente. Os custos da vazão de captação e da vazão de diluição foram adotados em $\mathrm{R} \$ 0,008 / \mathrm{m}^{3}$ e $\mathrm{R} \$ 0,01 / \mathrm{m}^{3}$. Para captação, eles são inferiores aos propostos pelo Estado de São Paulo e para o rio Paraíba do Sul. Para a diluição, o valor adotado é igual ao valor de captação proposto pelo Estado de São Paulo.

A Tabela 5.11 apresenta valores para o Lançamento 1, para os cenários de Classes 2 e 4, de: vazão de diluição, custo da vazão de diluição no rio, vazão liberada por lançamento no rio, vazão liberada para outorga no rio, vazão de diluição da carga de poluente retirada através de captação, custo da vazão de diluição para captação, custo total de lançamento e também valores médios calculados. Apenas a Tabela 5.11 apresenta valores calculados no rio para cada trecho e elemento, as demais tabelas apresentam valores médios. Esta tabela também apresenta o valor de vazão de diluição para a captação localizada a jusante do Lançamento 1.

A vazão liberada por lançamento representa o quanto de vazão o usuário está deixando de pagar quando levado em consideração o processo de autodepuração do rio. A vazãa liberada para outorga representa o quanto de vazão está sendo disponibilizado no corpo hídrico para novas outorgas.

O custo total de lançamento, para cada usuário-poluidor, representa o custo médio da vazão de diluição ao longo do rio somado aos custos da vazão de diluição para captação (vazão de diluição da carga de poluente retirada do rio através de captação). Caso o lançamento do usuário-poluidor não interfira na qualidade da água captada pelos usuários de jusante, o da vazão de diluição para captação será zero.

Ressalte-se que nesta aplicação foi, simulada apenas a variável DBO, mas caso outras variáveis fossem simuladas, o custo da vazão de diluição ao longo do rio seria o custo referente à maior vazão de diluição ao longo do corpo receptor dentre os poluentes simulados, assim como o custo da vazão de diluição para captação estaria associado à soma das maiores vazões de diluição para captação dentre os poluentes simulados, referentes aos respectivos lançamentos de montante. 
Tabela 5.11 - Vazão de diluição, vazão liberada e custos, para o Lançamento 1

\begin{tabular}{|c|c|c|c|c|c|c|c|c|c|}
\hline \multicolumn{7}{|c|}{ Rio } & \multicolumn{2}{|c|}{ Captação } & \multirow{2}{*}{$\begin{array}{c}\text { Custo Total } \\
\text { (Rio+Cap.) } \\
(\mathrm{R} \$ / \mathrm{d})\end{array}$} \\
\hline Classe & Trecho & Elemento & $\begin{array}{c}\mathrm{QD} \\
\left(\mathrm{m}^{3} / \mathrm{s}\right)\end{array}$ & $\begin{array}{c}\text { Custo QD } \\
(\mathrm{R} \$ / \mathrm{d})\end{array}$ & $\begin{array}{c}\text { QL p/ lanç. } \\
\left(\mathrm{m}^{3} / \mathrm{s}\right)\end{array}$ & $\begin{array}{l}\text { QL p/ out. } \\
\qquad\left(\mathrm{m}^{3} / \mathrm{s}\right)\end{array}$ & $\begin{array}{l}\text { QDc } \\
\left(\mathrm{m}^{3} / \mathrm{s}\right)\end{array}$ & $\begin{array}{l}\text { Custo } \\
(\mathrm{R} \$ / \mathrm{d})\end{array}$ & \\
\hline \multirow{11}{*}{2} & 2 & 5 & 0,56 & 483,84 & 0,00 & 0,00 & \multirow{10}{*}{0,002} & \multirow{10}{*}{1,42} & \multirow{11}{*}{303,82} \\
\hline & 2 & 6 & 0,49 & 423,36 & 0,06 & 0,08 & & & \\
\hline & 2 & 7 & 0,44 & 380,16 & 0,12 & 0,15 & & & \\
\hline & 3 & 1 & 0,40 & 345,60 & 0,16 & $-4,95$ & & & \\
\hline & 3 & 2 & 0,35 & 302,40 & 0,20 & $-4,32$ & & & \\
\hline & 3 & 3 & 0,31 & 267,84 & 0,25 & $-3,73$ & & & \\
\hline & 3 & 4 & 0,28 & 241,92 & 0,28 & $-3,24$ & & & \\
\hline & 3 & 5 & 0,25 & 216,00 & 0,31 & $-2,79$ & & & \\
\hline & 3 & 6 & 0,22 & 190,08 & 0,33 & $-2,37$ & & & \\
\hline & 3 & 7 & 0,20 & 172,80 & 0,36 & $-2,53$ & & & \\
\hline & \multicolumn{2}{|c|}{ Valores médios = } & 0,35 & 302,40 & 0,21 & $-2,37$ & & & \\
\hline \multirow{11}{*}{4} & 2 & 5 & 0,28 & 241,92 & 0,00 & 0,47 & \multirow{10}{*}{0,001} & \multirow{10}{*}{0,71} & \multirow{11}{*}{152,77} \\
\hline & 2 & 6 & 0,25 & 216,00 & 0,03 & 0,53 & & & \\
\hline & 2 & 7 & 0,22 & 190,08 & 0,06 & 0,59 & & & \\
\hline & 3 & 1 & 0,20 & 172,80 & 0,08 & $-1,88$ & & & \\
\hline & 3 & 2 & 0,18 & 155,52 & 0,10 & $-1,55$ & & & \\
\hline & 3 & 3 & 0,16 & 138,24 & 0,12 & $-1,24$ & & & \\
\hline & 3 & 4 & 0,14 & 120,96 & 0,14 & $-0,97$ & & & \\
\hline & 3 & 5 & 0,12 & 103,68 & 0,15 & $-0,72$ & & & \\
\hline & 3 & 6 & 0,11 & 95,04 & 0,17 & $-0,50$ & & & \\
\hline & 3 & 7 & 0,10 & 86,40 & 0,18 & $-0,55$ & & & \\
\hline & \multicolumn{2}{|c|}{ Valores médios $=$} & 0,18 & 152,06 & 0,10 & $-0,58$ & & & \\
\hline
\end{tabular}

QD - Vazão de diluição; QL - Vazão liberada; QDc - Vazão de diluição para captação; Cap. - Captação; Out. - Outorga; Lanç. - Lançamento

A Tabela 5.12 apresenta valores de vazão de diluição, vazão liberada, vazão de diluição de captação e custos, para os Lançamentos de 1 a 10 (L1 a L10) apresentados na Tabela 4.9, na pág. 86. Já a Tabela 5.13 apresenta valores do custo de captação, assim como o bônus obtido por captação. O bônus de captação representa o custo da vazão de diluição da carga de poluente retirada do rio através de captação. Logo, no exemplo simulado, representa a soma dos valores calculados para a diluição da carga de DBO pertencente a cada usuário-poluidor de montante. 
Tabela 5.12 - Vazão de diluição, vazão liberada, vazão de diluição de captação e custos, em função da Classe de Uso

\begin{tabular}{|c|c|c|c|c|c|c|c|c|c|c|c|c|c|}
\hline \multirow[t]{2}{*}{ Classe } & \multicolumn{3}{|c|}{ Rio e Captação } & \multicolumn{8}{|c|}{ Lançamentos } & \multirow[b]{2}{*}{ L9 } & \multirow[b]{2}{*}{$\mathrm{L} 10$} \\
\hline & & & & $\mathrm{L} 1$ & L2 & L3 & L4 & L5 & L6 & L7 & L8 & & \\
\hline \multirow{6}{*}{2} & \multirow{3}{*}{ Rio } & QD & $\left(\mathrm{m}^{3} / \mathrm{s}\right)$ & 0,351 & 2,855 & 0,390 & 0,000 & 0,548 & 4,551 & 0,217 & 0,000 & 7,217 & 0,603 \\
\hline & & QL lanç. & $\left(\mathrm{m}^{3} / \mathrm{s}\right)$ & 0,207 & 2,421 & 0,168 & 0,000 & 0,300 & 3,887 & 0,010 & 0,000 & 5,927 & 0,176 \\
\hline & & Custo QD & $(R \$ / d)$ & 304,0 & 2467,0 & 337,0 & 0,0 & 474,0 & 3932,0 & 187,0 & 0,0 & 6235,0 & 521,0 \\
\hline & \multirow[t]{2}{*}{ Cap. } & QDc & $\left(\mathrm{m}^{3} / \mathrm{s}\right)$ & 0,002 & 0,029 & 0,002 & 0,000 & 0,003 & 0,032 & 0,000 & 0,000 & 0,000 & 0,000 \\
\hline & & Custo QDc & $(\mathrm{R} \$ / \mathrm{d})$ & 1,4 & 25,1 & 1,3 & 0,0 & 2,5 & 27,4 & 0,0 & 0,0 & 0,0 & 0,0 \\
\hline & \multicolumn{2}{|c|}{ Custo Total } & $(\mathrm{R} \$ / \mathrm{d})$ & 305,4 & 2492,1 & 338,3 & 0,0 & 476,5 & 3959,4 & 187,0 & 0,0 & 6235,0 & 521,0 \\
\hline \multirow{6}{*}{4} & \multirow{3}{*}{ Rio } & & $\left(\mathrm{m}^{3} / \mathrm{s}\right)$ & 0,176 & 1,428 & 0,195 & 0,000 & 0,274 & 2,275 & 0,108 & 0,000 & 3,608 & 0,301 \\
\hline & & QL lanç. & $\left(\mathrm{m}^{3} / \mathrm{s}\right)$ & 0,104 & 1,211 & 0,084 & 0,000 & 0,150 & 1,944 & 0,005 & 0,000 & 2,964 & 0,088 \\
\hline & & Custo QD & $(\mathrm{R} \$ / \mathrm{d})$ & 152,0 & 1233,0 & 168,0 & 0,0 & 237,0 & 1966,0 & 94,0 & 0,0 & 3118,0 & 260,0 \\
\hline & \multirow[t]{2}{*}{ Cap. } & QDc & $\left(\mathrm{m}^{3} / \mathrm{s}\right)$ & 0,001 & 0,015 & 0,001 & 0,000 & 0,001 & 0,016 & 0,000 & 0,000 & 0,000 & 0,000 \\
\hline & & Custo QDc & $(\mathrm{R} \$ / \mathrm{d})$ & 0,710 & 12,550 & 0,660 & 0,000 & 1,250 & 13,680 & 0,000 & 0,000 & 0,000 & 0,000 \\
\hline & \multicolumn{2}{|c|}{ Custo Total } & $(R \$ / d)$ & 152,7 & 1245,6 & 168,7 & 0,0 & 238,3 & 1979,7 & 94,0 & 0,0 & 3118,0 & 260,0 \\
\hline
\end{tabular}

QD - Vazão de diluição; QL - Vazão Liberada; QDc - Vazão de diluição para captação; Cap. - Captação

Tabela 5.13 - Valores de captação em função da Classe de Uso

\begin{tabular}{|c|c|r|r|r|r|}
\hline Classe & Captação & $\begin{array}{c}\mathrm{Q} \\
\left(\mathrm{m}^{3} / \mathrm{s}\right)\end{array}$ & $\begin{array}{c}\text { Custo } \\
(\mathrm{R} \$ / \mathrm{d})\end{array}$ & $\begin{array}{c}\text { Bônus } \\
(\mathrm{R} \$ / \mathrm{d})\end{array}$ & $\begin{array}{c}\text { Custo-Bônus } \\
(\mathrm{R} \$ / \mathrm{d})\end{array}$ \\
\hline \hline \multirow{3}{*}{2} & Cap.1 & 0,02 & 13,8 & 0,0 & 13,8 \\
& Cap.2 & 0,01 & 6,9 & 20,3 & $-13,3$ \\
& Cap.3 & 0,01 & 6,9 & 37,5 & $-30,5$ \\
\hline \multirow{4}{*}{4} & Cap.1 & 0,02 & 13,8 & 0,0 & 13,8 \\
& Cap.2 & 0,01 & 6,9 & 10,1 & $-3,2$ \\
& Cap.3 & & 6,9 & 18,7 & $-11,8$ \\
\hline
\end{tabular}

QC - Vazão de captação

Na Tabela 5.11 observa-se que a vazão de diluição da DBO decai ao longo do corpo receptor, assim como decai proporcionalmente o custo da vazão de diluição. A queda da vazão de diluição está relacionada diretamente ao processo de autodepuração do corpo receptor.

Através das Tabelas 5.11 e 5.12, é possível observar que a vazão de diluição no ponto de lançamento do efluente representa a soma da vazão de diluição com a vazão liberada por lançamento, somada à vazão de diluição para captação. Observa-se também que quanto mais restritiva for a Classe de Uso do corpo hídrico, maior a vazão requerida para diluição do poluente no rio e maior a vazão de diluição para captação e, portanto, maior o custo de lançamento. A vazão de diluição do poluente no rio, a vazão de diluição para captação, o custo de lançamento e a vazão liberada por lançamento são 
inversamente proporcionais à concentração máxima permissível de poluente no corpo hídrico.

Nos exemplos simulados, a concentração máxima permissível de DBO para a Classe 4 do rio é de $10 \mathrm{mg} / \mathrm{L}$. Já para a Classe 2, o valor é de $5 \mathrm{mg} / \mathrm{L}$. Assim, a vazão de diluição requerida para o respeito à Classe de Uso do corpo hídrico, para a Classe 2, é dobro da vazão de diluição necessária para a Classe 4. Logo, para um mesmo lançamento, o custo da vazão de diluição, para o rio enquadrado na Classe 2, é o dobro do custo para o rio enquadrado na Classe 4.

A Tabela 5.13 apresenta valores de captação em função das Classes de Uso simuladas. Nesta tabela, observa-se que o custo da vazão de captação independe da Classe de Uso, quando não levado em consideração a qualidade da água captada.

Considerando a qualidade da água, o custo de captação cai quanto pior for a qualidade da água, em virtude do maior custo da vazão de diluição para captação; assim também como cai o custo quanto mais restritiva for a Classe de Uso, devido à maior vazão de diluição para captação.

\section{$\underline{2^{\circ} . \text { Cenário }}$}

No Cenário 2, as vazões adotadas foram $\mathrm{Q}_{7,10}, \mathrm{Q}_{95}, \mathrm{Q}_{90}$ e Qm, assim como a Classe de Uso adotada foi a Classe 2, conferindo ao corpo hídrico valor máximo permissível de DBO de $5 \mathrm{mg} / \mathrm{L}$. Os custos da vazão de captação e da vazão de diluição foram adotados em R $\$ 0,008 / \mathrm{m}^{3}$ e R $\$ 0,01 / \mathrm{m}^{3}$, respectivamente. Para a captação, eles são inferiores aos propostos pelo Estado de São Paulo e para o rio Paraíba do Sul. Para a diluição, o valor adotado é igual ao valor de captação proposto pelo Estado de São Paulo.

A Tabela 5.14 apresenta valores para os Lançamentos de 10 a 18 (L10 a L18), apresentados na Tabela 4.9, na pág. 86, de: vazão de diluição, custo da vazão de diluição e vazão liberada por lançamento no rio. Assim como apresenta também valores de vazão de diluição para captação, custo da vazão de diluição para captação e custo total de lançamento. 
Tabela 5.14 - Vazão de diluição, vazão liberada por lançamento, vazão de diluição de captação e custos, em função da vazão simulada

\begin{tabular}{|c|c|c|c|c|c|c|c|c|c|c|c|c|}
\hline \multirow[t]{2}{*}{ Vazão } & \multirow{2}{*}{\multicolumn{3}{|c|}{ Rio e Captação }} & \multicolumn{9}{|c|}{ Lançamentos } \\
\hline & & & & L10 & L11 & L12 & L13 & L14 & L15 & L16 & L17 & L18 \\
\hline \multirow{6}{*}{ Q7,10 } & \multirow{3}{*}{ Rio } & QD & $\left(m^{3} / s\right)$ & 0,552 & 0,914 & 0,000 & 1,231 & 0,478 & 0,000 & 6,757 & 1,187 & 8,457 \\
\hline & & QL lanç. & $\left(\mathrm{m}^{3} / \mathrm{s}\right)$ & 0,214 & 0,554 & 0,000 & 0,796 & 0,081 & 0,000 & 4,805 & 0,114 & 0,412 \\
\hline & & Custo QD & $(\mathrm{R} \$ / \mathrm{d})$ & 477,0 & 789,0 & 0,0 & 1064,0 & 413,0 & 0,0 & 5838,0 & 1026,0 & 7307,0 \\
\hline & \multirow[t]{2}{*}{ Cap. } & QDc & $\left(\mathrm{m}^{3} / \mathrm{s}\right)$ & 0,000 & 0,000 & 0,000 & 0,000 & 0,000 & 0,000 & 0,000 & 0,000 & 0,000 \\
\hline & & Custo QDc & $(\mathrm{R} \$ / \mathrm{d})$ & 0,0 & 0,0 & 0,0 & 0,0 & 0,0 & 0,0 & 0,0 & 0,0 & 0,0 \\
\hline & \multicolumn{2}{|c|}{ Custo Total } & $(\mathrm{R} \$ / \mathrm{d})$ & 477,0 & 789,0 & 0,0 & 1064,0 & 413,0 & 0,0 & 5838,0 & 1026,0 & 7307,0 \\
\hline \multirow{6}{*}{ Q95 } & \multirow{3}{*}{ Rio } & QD & $\left(\mathrm{m}^{3} / \mathrm{s}\right)$ & 0,603 & 0,995 & 0,000 & 1,276 & 0,548 & 0,000 & 7,128 & 1,225 & 8,641 \\
\hline & & QL lanç. & $\left(\mathrm{m}^{3} / \mathrm{s}\right)$ & 0,176 & 0,513 & 0,000 & 0,789 & 0,033 & 0,000 & 4,671 & 0,093 & 0,356 \\
\hline & & Custo QD & $(\mathrm{R} \$ / \mathrm{d})$ & 521,0 & 859,0 & 0,0 & 1102,0 & 473,0 & 0,0 & 6158,0 & 1059,0 & 7466,0 \\
\hline & \multirow[t]{2}{*}{ Cap. } & QDc & $\left(\mathrm{m}^{3} / \mathrm{s}\right)$ & 0,000 & 0,000 & 0,000 & 0,000 & 0,000 & 0,000 & 0,000 & 0,000 & 0,000 \\
\hline & & Custo QDc & $(R \$ / d)$ & 0,0 & 0,0 & 0,0 & 0,0 & 0,0 & 0,0 & 0,0 & 0,0 & 0,0 \\
\hline & \multicolumn{2}{|c|}{ Custo Total } & $(R \$ / d)$ & 521,0 & 859,0 & 0,0 & 1102,0 & 473,0 & 0,0 & 6158,0 & 1059,0 & 7466,0 \\
\hline \multirow{6}{*}{ Q90 } & \multirow{3}{*}{ Rio } & QD & $\left(\mathrm{m}^{3} / \mathrm{s}\right)$ & 0,610 & 1,011 & 0,000 & 1,319 & 0,548 & 0,000 & 7,242 & 1,235 & 8,703 \\
\hline & & QL lanç. & $\left(\mathrm{m}^{3} / \mathrm{s}\right)$ & 0,169 & 0,503 & 0,000 & 0,756 & 0,027 & 0,000 & 4,610 & 0,096 & 0,342 \\
\hline & & Custo QD & $(\mathrm{R} \$ / \mathrm{d})$ & 527,0 & 873,0 & 0,0 & 1140,0 & 474,0 & 0,0 & 6257,0 & 1067,0 & 7520,0 \\
\hline & \multirow[t]{2}{*}{ Cap. } & QDc & $\left(\mathrm{m}^{3} / \mathrm{s}\right)$ & 0,000 & 0,000 & 0,000 & 0,000 & 0,000 & 0,000 & 0,000 & 0,000 & 0,000 \\
\hline & & Custo QDC & $(R \$ / d)$ & 0,0 & 0,0 & 0,0 & 0,0 & 0,0 & 0,0 & 0,0 & 0,0 & 0,0 \\
\hline & \multicolumn{2}{|c|}{ Custo Total } & $(\mathrm{R} \$ / \mathrm{d})$ & 527,0 & 873,0 & 0,0 & 1140,0 & 474,0 & 0,0 & 6257,0 & 1067,0 & 7520,0 \\
\hline \multirow{6}{*}{ Qm } & \multirow{3}{*}{ Rio } & QD & $\left(\mathrm{m}^{3} / \mathrm{s}\right)$ & 0,812 & 1,241 & 0,000 & 1,582 & 0,000 & 0,000 & 8,416 & 1,374 & 9,123 \\
\hline & & QL lanç. & $\left(\mathrm{m}^{3} / \mathrm{s}\right)$ & 0,000 & 0,353 & 0,000 & 0,565 & 0,000 & 0,000 & 3,824 & 0,000 & 0,213 \\
\hline & & Custo QD & $(\mathrm{R} \$ / \mathrm{d})$ & 702,0 & 1072,0 & 0,0 & 1367,0 & 0,0 & 0,0 & 7272,0 & 1187,0 & 7883,0 \\
\hline & \multirow[t]{2}{*}{ Cap. } & QDc & $\left(\mathrm{m}^{3} / \mathrm{s}\right)$ & 0,000 & 0,000 & 0,000 & 0,000 & 0,000 & 0,000 & 0,000 & 0,000 & 0,000 \\
\hline & & Custo QDc & $(\mathrm{R} \$ / \mathrm{d})$ & 0,0 & 0,0 & 0,0 & 0,0 & 0,0 & 0,0 & 0,0 & 0,0 & 0,0 \\
\hline & \multicolumn{2}{|c|}{ Custo Total } & $(R \$ / d)$ & 702,0 & 1072,0 & 0,0 & 1367,0 & 0,0 & 0,0 & 7272,0 & 1187,0 & 7883,0 \\
\hline
\end{tabular}

QD - Vazão de diluição; QL - Vazão Liberada; QDc - Vazão de diluição para captação; Cap. - Captação

A Tabela 5.15 apresenta custos para vazão e bônus de captação. Já a Tabela 5.16 apresenta valores médios de vazão liberada para novas outorgas, em função da vazão simulada para o corpo hídrico. 
Tabela 5.15 - Valores de captação em função da vazão simulada

\begin{tabular}{|c|c|r|r|r|r|}
\hline $\begin{array}{c}\text { Regime de } \\
\text { Vazão }\end{array}$ & Captação & $\begin{array}{c}\text { QC } \\
\left(\mathrm{m}^{3} / \mathrm{s}\right)\end{array}$ & $\begin{array}{c}\text { Custo } \\
(\mathrm{R} \$ / \mathrm{d})\end{array}$ & $\begin{array}{r}\text { Bônus } \\
(\mathrm{R} \$ / \mathrm{d})\end{array}$ & $\begin{array}{c}\text { Custo-Bônus } \\
(\mathrm{R} \$ / \mathrm{d})\end{array}$ \\
\hline \hline \multirow{3}{*}{ Q7,10 } & Cap.1 & 0,02 & 13,8 & 0,0 & 13,8 \\
& Cap.2 & 0,01 & 6,9 & 32,7 & $-25,8$ \\
& Cap.3 & 0,01 & 6,9 & 55,7 & $-48,8$ \\
\hline \multirow{4}{*}{ Q95 } & Cap.1 & 0,02 & 13,8 & 0,0 & 13,8 \\
& Cap.2 & 0,01 & 6,9 & 20,3 & $-13,3$ \\
& Cap.3 & 0,01 & 6,9 & 37,5 & $-30,5$ \\
\hline \multirow{4}{*}{ Q90 } & Cap.1 & 0,02 & 13,8 & 0,0 & 13,8 \\
& Cap.2 & 0,01 & 6,9 & 18,4 & $-11,5$ \\
& Cap.3 & 0,01 & 6,9 & 34,1 & $-27,2$ \\
\hline \multirow{3}{*}{ Qm } & Cap.1 & 0,02 & 13,8 & 0,0 & 13,8 \\
& Cap.2 & 0,01 & 6,9 & 8,9 & $-2,0$ \\
& Cap.3 & 0,01 & 6,9 & 16,9 & $-10,0$ \\
\hline
\end{tabular}

QC - Vazão de captação

Tabela 5.16 - Vazão liberada para outorga em função do regime de vazão e da Classe de Uso simuladas

\begin{tabular}{|c|r|r|r|r|}
\hline \multirow{2}{*}{$\begin{array}{c}\text { Regime de } \\
\text { Vazão }\end{array}$} & \multicolumn{2}{|c|}{ Posto Fluviométrico $\left(\mathrm{m}^{3} / \mathrm{s}\right)$} & \multicolumn{2}{|c|}{ Q média do rio Lib. Outorga $\left(\mathrm{m}^{3} / \mathrm{s}\right)$} \\
\cline { 2 - 5 } & 3E-108 & 4E-017 & Classe 2 & Classe 4 \\
\hline \hline Q7,10 & 0,35 & 2,54 & $-1,56$ & 0,22 \\
Q95 & 0,76 & 3,94 & $-1,32$ & 0,79 \\
Q90 & 0,85 & 4,41 & $-1,24$ & 0,97 \\
Qm & 1,66 & 10,33 & $-0,57$ & 3,06 \\
\hline
\end{tabular}

Diante de um mesmo cenário de lançamentos e captações no corpo hídrico, quanto maior a vazão, menor a concentração de poluente. Através da Tabela 5.14, observa-se que o aumento da vazão proporciona o aumento da vazão de diluição no rio, logo, maior o custo de lançamento; já para a vazão de diluição da carga de poluente retirada através de captação, quanto maior a vazão do rio, menor a carga e, conseqüentemente, menor o custo.

O regime de vazão adotado para o rio interfere no custo de lançamento do efluente porque quanto maior a vazão, maior será a profundidade média do sistema. A profundidade média é inversamente proporcional à quantidade de poluente sedimentada no rio. Portanto, quanto maior a vazão, maior a quantidade de poluente em suspensão, logo, maior a vazão de diluição no rio e menor a quantidade de poluente sedimentado. RODRIGUES (2000) 
O regime de vazão do rio também interfere na quantidade de carga de poluente retirada dele através de captação, porque quanto maior a vazão, maior a diluição do poluente no corpo d'água, portanto, menor o fluxo de massa do poluente na seção transversal do ponto de captação, isto é, menores são as concentrações resultantes. RODRIGUES (2000)

Devido à menor taxa de sedimentação no rio com o aumento da vazão, quanto maior a vazão, menor a vazão liberada por lançamento, logo, maior a vazão de diluição no rio, porque, como já explicado, a vazão de diluição de lançamento representa a soma da vazão de diluição com a vazão liberada por lançamento somada à vazão de diluição para captação.

Através da Tabela 5.16, observou-se que, diante de um mesmo cenário de lançamento e captação, quanto maior a vazão do corpo hídrico, maior a vazão liberada para outorga, assim como quanto mais restritiva for a Classe de Uso do rio, menor a vazão liberada para outorga.

O regime de vazão adotado para o rio não interfere no custo da vazão captada quando não é levada em consideração a qualidade da água captada. Considerando-se esta última, quanto mais poluído o rio, ou quanto menor a vazão do corpo hídrico para um mesmo cenário de lançamento e captação, menor o custo de captação e maior o custo de lançamento. Quanto mais carga de poluente for retirada do rio por pontos de captação, menor a utilização da capacidade assimilativa do rio para a carga lançada.

No cenário simulado para a Classe 2, mesmo diante de uma vazão menos restritiva (Qm), a vazão liberada para outorga ao longo do rio foi negativa, já para a Classe 4 a vazão liberada para outorga foi positiva, mesmo no regime mais restritivo simulado $\left(\mathrm{Q}_{7,10}\right)$. Isto mostra o grau de interferência da Classe de Uso de um rio no processo de outorga pelo uso da água. 


\section{$\underline{3^{\circ} . \text { Cenário }}$}

No Cenário 3, a vazão de referência adotada foi a Q95, assim como a Classe de Uso adotada foi a Classe 2, conferindo ao corpo hídrico valor de DBO de $5 \mathrm{mg} / \mathrm{L}$. Os custos unitários da vazão de diluição (QD) e da vazão de captação (QC) foram adotados em:

- $\mathrm{R} \$ 0,01 / \mathrm{m}^{3}$ QD e R\$ 0,008/ $\mathrm{m}^{3}$ QC. Para a captação, é inferior aos propostos pelo Estado de São e para o rio Paraíba do Sul. Para a diluição, o valor adotado representa o valor de captação proposto pelo Estado de São Paulo;

- $\quad \mathrm{R} \$ 0,0005 / \mathrm{m}^{3}$ QD da DBO e R\$ 0,01/ $\mathrm{m}^{3}$ QC. Estes valores representam valores propostos pela metodologia do Conselho Estadual de Recursos Hídricos - CRH (através do custo de R $\$ 0,10 / \mathrm{kg}$ DBO e supondo neste trabalho a Classe de Uso do rio como 2) e pelo Estado de São Paulo através do Projeto de Lei 676/00, respectivamente;

- $\quad \mathrm{R} \$ 0,02 \mathrm{~m}^{3} / \mathrm{QD}$ e R\$ 0,02/ $\mathrm{m}^{3}$ QC. Estes valores representam valores propostos para cobrança no rio Paraíba do Sul através da Deliberação CEIVAP n 08/2001.

A Tabela 5.17, para os Lançamentos de 1 a 10 (L1 a L10) apresentados na Tabela 4.9, na página 86 , mostra valores de vazão de diluição e custo da vazão de diluição no rio. Também apresenta valores de vazão de diluição para captação (vazão de diluição da carga de poluente retirada do rio através de captação), custo da vazão de diluição para captação e custo total de lançamento. 
Tabela 5.17 - Custos de lançamento em função dos valores unitários adotados para diluição e captação

\begin{tabular}{|c|c|c|c|c|c|c|c|c|c|c|c|c|}
\hline & \multirow{2}{*}{\multicolumn{2}{|c|}{ Rio e Captação }} & \multicolumn{10}{|c|}{ Lançamentos } \\
\hline \multirow{15}{*}{\begin{tabular}{l}
0 \\
0 \\
Oे \\
\multirow{0}{0}{} \\
0
\end{tabular}} & & & L1 & L2 & L3 & L4 & L5 & L6 & L7 & L8 & L9 & L10 \\
\hline & \multirow{5}{*}{ Rio } & $\left(\mathrm{m}^{3} / \mathrm{s}\right)$ & 0,351 & 2,855 & 0,390 & 0,000 & 0,548 & 4,551 & 0,217 & 0,000 & 7,217 & 0,603 \\
\hline & & Custo $\left(\mathrm{R} \$ / \mathrm{m}^{3}\right)$ & \multicolumn{10}{|c|}{ Custo (R\$/dia) } \\
\hline & & $Q D=0,01$ & 304,0 & 2467,0 & 337,0 & 0,0 & 474,0 & 3932,0 & 187,0 & 0,0 & 6235,0 & 521,0 \\
\hline & & $Q D=0,0005$ & 15,0 & 123,0 & 17,0 & 0,0 & 24,0 & 197,0 & 9,0 & 0,0 & 312,0 & 26,0 \\
\hline & & $Q D=0,02$ & 608,0 & 4934,0 & 674,0 & 0,0 & 948,0 & 7864,0 & 374,0 & 0,0 & 12470,0 & 1042,0 \\
\hline & \multirow{5}{*}{ Cap. } & QDc & 0,002 & 0,029 & 0,002 & 0,000 & 0,003 & 0,032 & 0,000 & 0,000 & 0,000 & 0,000 \\
\hline & & Custo $\left(\mathrm{R} \$ / \mathrm{m}^{3}\right)$ & \multicolumn{10}{|c|}{ Custo (R\$/dia) } \\
\hline & & $Q D=0,01$ & 1,4 & 25,1 & 1,3 & 0,0 & 2,5 & 27,4 & 0,0 & 0,0 & 0,0 & 0,0 \\
\hline & & $Q D=0,0005$ & 0,1 & 1,3 & 0,1 & 0,0 & 0,1 & 1,4 & 0,0 & 0,0 & 0,0 & 0,0 \\
\hline & & $Q D=0,02$ & 2,8 & 50,2 & 2,6 & 0,0 & 5,0 & 54,7 & 0,0 & 0,0 & 0,0 & 0,0 \\
\hline & \multirow{4}{*}{$\begin{array}{l}\stackrel{\circ}{\mathbb{N}} \\
0 \\
+ \\
\stackrel{\circ}{\widetilde{Y}}\end{array}$} & Custo $\left(\mathrm{R} \$ / \mathrm{m}^{3}\right)$ & \multicolumn{10}{|c|}{ Custo Total ( $\mathrm{R} \$ / \mathrm{dia})$} \\
\hline & & $Q D=0,01$ & 305,4 & 2492,1 & 338,3 & 0,0 & 476,5 & 3959,4 & 187,0 & 0,0 & 6235,0 & 521,0 \\
\hline & & $Q D=0,0005$ & 15,1 & 124,3 & 17,1 & 0,0 & 24,1 & 198,4 & 9,0 & 0,0 & 312,0 & 26,0 \\
\hline & & $Q D=0,02$ & 610,8 & 4984,2 & 676,6 & 0,0 & 953,0 & 7918,7 & 374,0 & 0,0 & 12470,0 & 1042,0 \\
\hline
\end{tabular}

QD - Vazão de diluição; QDc - Vazão de diluição para captação; Cap. - Captação

A Tabela 5.18 apresenta valores de captação em função dos custos unitários adotados para as vazões de captação e de diluição.

Tabela 5.18 - Custo de captação em função dos valores unitários adotados para diluição e captação

\begin{tabular}{|c|c|r|r|r|r|}
\hline $\begin{array}{c}\text { Custo } \\
\left(\mathrm{R} \$ / \mathrm{m}^{3}\right)\end{array}$ & Captação & $\begin{array}{c}\mathrm{Q} \\
\left(\mathrm{m}^{3} / \mathrm{s}\right)\end{array}$ & $\begin{array}{c}\text { Custo } \\
(\mathrm{R} \$ / \mathrm{d})\end{array}$ & $\begin{array}{c}\text { Bônus } \\
(\mathrm{R} \$ / \mathrm{d})\end{array}$ & $\begin{array}{c}\text { Custo-Bônus } \\
(\mathrm{R} \$ / \mathrm{d})\end{array}$ \\
\hline \hline $\mathrm{QD}=0,01$ & Cap.1 & 0,02 & 13,8 & 0,0 & 13,8 \\
$\mathrm{QC}=0,008$ & Cap.2 & 0,01 & 6,9 & 20,3 & $-13,3$ \\
& Cap.3 & 0,01 & 6,9 & 37,5 & $-30,5$ \\
\hline $\mathrm{QD}=0,0005$ & Cap.1 & 0,02 & 17,3 & 0,0 & 17,3 \\
$\mathrm{QC}=0,01$ & Cap.2 & 0,01 & 8,6 & 1,0 & 7,6 \\
& Cap.3 & 0,01 & 8,6 & 1,9 & 6,8 \\
\hline $\mathrm{QD}=0,02$ & Cap.1 & 0,02 & 34,6 & 0,0 & 34,6 \\
$\mathrm{QC}=0,02$ & Cap.2 & 0,01 & 17,3 & 40,5 & $-23,2$ \\
& Cap.3 & 0,01 & 17,3 & 74,9 & $-57,6$ \\
\hline
\end{tabular}

QC - Vazão de captação; QD - Vazão de diluição

O valor unitário para diluição adotado para o rio Paraíba do Sul $\left(\mathrm{R} \$ 0,02 / \mathrm{m}^{3}\right)$ é o dobro do valor indicado neste trabalho como valor unitário de diluição proposto para o Estado de São Paulo $\left(\mathrm{R} \$ 0,01 / \mathrm{m}^{3}\right)$. Através das simulações realizadas para o Cenário 3, observou-se que os valores unitários adotados para diluição refletem diretamente e proporcionalmente no custo de lançamento. (Ver Tabela 5.17) 
Através da metodologia proposta pelo Conselho Estadual de Recursos Hídricos - CRH do Estado de São Paulo, usando o valor do Preço Unitário da DBO sugerido em R\$ 0,10/kg DBO e adotando no cenário simulado a Classe de Uso do rio em Classe 2, obtém-se um custo unitário de vazão de diluição de $\mathrm{R} \$ 0,0005 / \mathrm{m}^{3}$.

Adotando-se o custo unitário da vazão de diluição em $\mathrm{R} \$ 0,0005 / \mathrm{m}^{3}$, os custos dos lançamentos simulados representam em média $2,5 \%$ da média dos custos de lançamento obtidos adotando-se o valor unitário da vazão de diluição em $\mathrm{R} \$ 0,02 / \mathrm{m}^{3}$ (valor unitário de diluição adotado para o rio Paraíba do Sul) e 5\% dos custos de lançamento com o valor unitário de diluição adotado em $\mathrm{R} \$ 0,01 / \mathrm{m}^{3}$. Isto reflete a discrepância de valores e mostra a importância dos cuidados que devem ser tomados quando se estabelece o custo de lançamento em termos de carga.

Quanto maior o custo unitário da vazão de captação, maior o custo de captação. Já através da Tabela 5.18 observa-se que o bônus de captação está diretamente relacionado ao custo unitário da vazão de diluição e à qualidade da água captada.

Quanto pior a qualidade da água captada, maior o bônus. Isto pode ser observado através da Tabela 5.18, para as captações 2 e 3, que são numericamente iguais. A Captação 3, localizada a jusante da Captação 2, apresenta uma qualidade pior de suas águas, logo, o bônus da Captação 3 é maior que o bônus da Captação 2. Já a Captação 1, localizada a montante de todos os lançamentos simulados, não sofre interferência na qualidade de sua água captada de nenhum lançamento, logo, o bônus de captação é zero.

A Tabela 5.19 apresenta um resumo dos resultados obtidos com os cenários simulados através da aplicação do SSD RB na bacia do rio Jundiaí. 
Tabela 5.19 - Cenários de aplicação do SSD RB e conclusões obtidas

\begin{tabular}{|c|c|c|}
\hline Cen. & Objetivos & Conclusões \\
\hline 1 & $\begin{array}{l}\text { Verificar a interferência da } \\
\text { Classe de Uso de um rio em: } \\
\text { - Vazão de diluição ao } \\
\text { longo do rio; } \\
\text { - Vazão de diluição da } \\
\text { carga de poluente } \\
\text { retirada através de } \\
\text { captação; } \\
\text { Vazão liberada para } \\
\text { novas outorgas; } \\
\text { Vazão liberada por } \\
\text { lançamento; } \\
\text { Custo de lançamento } \\
\text { e captação. }\end{array}$ & $\begin{array}{l}\text { - Quanto mais restritiva for a Classe de Uso do corpo hídrico, } \\
\text { maior a vazão de diluição do poluente no rio e maior a vazão de } \\
\text { diluição para captação, logo, maior o custo de lançamento. } \\
\text { - O custo de captação independe da Classe de Uso, quanto não } \\
\text { levado em consideração a qualidade da água captada. } \\
\text { Considerando-se esta, o custo cai quanto pior for a qualidade da } \\
\text { água, assim como o custo também cai quanto mais restritiva for } \\
\text { a Classe de Uso devido à maior vazão de diluição da carga de } \\
\text { poluente retirada do rio. } \\
\text { - Quanto mais restritiva a Classe de Uso do corpo receptor, } \\
\text { menor a vazão liberada para outorga. } \\
\text { - A vazão de diluição do poluente no rio, a vazão de diluição } \\
\text { para captação, o custo de lançamento e a vazão liberada por } \\
\text { lançamento são inversamente proporcionais à concentração } \\
\text { máxima permissível de poluente no corpo hídrico. }\end{array}$ \\
\hline 2 & $\begin{array}{l}\text { Verificar a interferência do } \\
\text { regime de vazão adotado para } \\
\text { o corpo hídrico em: } \\
\text { - Vazão de diluição ao } \\
\text { longo do rio; } \\
\text { - Vazão de diluição da } \\
\text { carga de poluente } \\
\text { retirada através de } \\
\text { captação; } \\
\text { Vazão liberada para } \\
\text { novas outorgas; } \\
\text { Vazão liberada por } \\
\text { lançamento; } \\
\text { Custo de lançamento e } \\
\text { captação. }\end{array}$ & $\begin{array}{l}\text { - Diante de um mesmo cenário de lançamentos e captações no } \\
\text { corpo hídrico, quanto maior a vazão, menor a concentração de } \\
\text { poluente. Quanto menor a concentração de poluente no corpo } \\
\text { hídrico, maior a vazão liberada para outorga. } \\
\text { - O regime de vazão adotado para o rio não interfere no custo da } \\
\text { vazão captada, quando não levado em consideração a qualidade } \\
\text { da água. Considerando-se esta, quanto pior qualidade da água, } \\
\text { para um mesmo cenário de lançamentos e captações, menor o } \\
\text { custo de captação e maior o custo de lançamento. } \\
\text { - Com a diminuição da vazão, para um mesmo cenário de } \\
\text { lançamentos e captações, maior a carga de poluente retirada do } \\
\text { rio por pontos de captação, assim menor a utilização da } \\
\text { capacidade assimilativa do rio para a carga lançada, logo, maior } \\
\text { o custo de lançamento e menor o custo de captação devido ao } \\
\text { bônus de captação. } \\
\text { - Devido à menor taxa de sedimentação de poluente no rio com } \\
\text { o aumento da vazão, maior a vazão de diluição ao longo do } \\
\text { corpo receptor e menor a vazão liberada por lançamento. A } \\
\text { vazão liberada por lançamento representa o quanto de vazão o } \\
\text { usuário está deixando de pagar quando levado em consideração } \\
\text { o processo de autodepuração. }\end{array}$ \\
\hline
\end{tabular}




\begin{tabular}{|c|l|l|}
\hline Cen. & \multicolumn{1}{|c|}{ Objetivo } & \multicolumn{1}{c|}{ Conclusões } \\
\hline 3 & Verificar a interferência dos & - Os valores unitários adotados para diluição e captação \\
custos unitários de captação e & refletem-se direta e proporcionalmente no custo de lançamento \\
de diluição na cobrança pelo & e captação. Isto mostra a importância dos cuidados que devem \\
uso da água. & $\begin{array}{l}\text { ser tomados com os valores unitários estabelecidos para } \\
\text { captação e, principalmente, para lançamento, quanto estes são } \\
\text { estabelecidos em termos de carga. } \\
\text { - Para a captação, considerando a qualidade da água captada, } \\
\text { quanto pior a qualidade da água, menor o custo de captação. O } \\
\text { bônus de captação está diretamente relacionado ao custo } \\
\text { unitário da vazão de diluição e à qualidade da água captada. } \\
\text { - O ponto de captação localizado a montante de todos os } \\
\text { lançamentos simulados não sofre interferência de nenhum } \\
\text { lançamento, logo, o bônus de captação é zero, assim como o } \\
\text { mesmo também é zero para os pontos de captação que não } \\
\text { sofrem interferência de lançamentos de montante devido ao } \\
\text { processo de autodepuração. }\end{array}$ \\
\hline
\end{tabular}




\section{Capítulo 6}

\section{CONCLUSÕES E RECOMENDAÇÕES}

\subsection{Conclusões}

Neste trabalho, através do desenvolvimento e da aplicação do SSD RB, conclui-se que, dentro do contexto de gestão de recursos hídricos, o SSD RB pode ser visto como uma ferramenta de gestão quali-quantitativa para os processos de outorga e cobrança pelo uso da água visando à articulação aos demais instrumentos da Política Nacional de Recursos Hídricos, ou seja, Plano de Recursos Hídricos, enquadramento dos corpos d'água em suas respectivas classes de uso e Sistema de Informação de Recursos Hídricos. Este sistema trata a outorga de lançamento e a outorga de captação a partir da mesma variável de decisão, ou seja, volume outorgado.

O SSD RB possibilita a aplicação da cobrança pelo uso da água de uma forma mais racional e eficaz, o que pode conscientizar o usuário-poluidor a reduzir a carga de poluição de seu efluente. No SSD RB, através dos cálculos realizados pelo modelo RM1, é quantificada a vazão de diluição do poluente ao longo do rio, considerando o processo de autodepuração, o regime de vazão e o enquadramento em classes de uso do corpo hídrico. Dessa forma, o sistema oferece a capacidade de racionalizar o custo do usuário, ao mesmo tempo em que induz a uma alocação eficiente dos recursos hídricos.

No SSD RB, através dos cálculos realizados pelo modelo RM1, quanto pior a qualidade da água captada no rio, menor o custo de captação e maior o custo de lançamento dos usuários responsáveis pela poluição. Assim, o usuário-poluidor é o que mais paga, 
induzindo a reversão da poluição dos rios, já que, na maioria das vezes, esta é a principal causa de escassez de água nos grandes centros urbanos, como, por exemplo, a Região Metropolitana de São Paulo.

Ressalte-se que, para lançamentos com vários poluentes simulados, a vazão de diluição considerada no sistema desenvolvido, tanto para a vazão de diluição ao longo do eixo longitudinal do rio como para a vazão de diluição para captação (vazão de diluição da carga de poluente retirada do rio através de captação), é a maior vazão de diluição do conjunto de poluentes simulados, considerando que esta vazão já dilui todos os demais poluentes simulados. Logo, esta vazão passa a ser a vazão considerada para a cobrança pelo uso da água.

Quanto maior o grau de poluição de um rio, tanto maior o custo de reversão da poluição. Uma arrecadação mais justa dos usuários da bacia, associada à respectiva transparência na alocação dos recursos arrecadados, pode servir como estímulo para que o Comitê de Bacia, em regiões mais críticas de poluição, decida por um valor maior para a cobrança pelo uso da água, já que nestas regiões os próprios usuários tendem a ser os mais interessados na reversão da poluição. Isto reflete a importância dos recursos arrecadados serem aplicados diretamente na bacia hidrográfica em que foram gerados, para o devido atendimento às metas estabelecidas nos Planos de Recursos Hídricos.

Em regiões onde existe água em abundância, os comitês podem decidir por não cobrar, assim como podem decidir aplicar custos unitários para captação e lançamento simbólicos. A segunda alternativa talvez seja a mais aconselhável, na medida que pode induzir a um melhor planejamento e gerenciamento dos recursos hídricos, porque pode promover a conscientização desses usuários do real valor da água como recurso natural e econômico e também possibilitar a arrecadação de recursos financeiros para o monitoramento da bacia e a educação ambiental da sociedade.

O SSD RB pode servir de apoio para a elaboração dos Planos de Recursos Hídricos, na medida que o mesmo possibilita a articulação entre os custos unitários estabelecidos para a captação e o lançamento, o enquadramento em classes de uso e o regime de vazão adotado para o corpo hídrico. 
Assim, o SSD RB serve também de apoio nas seguintes decisões de aprovação pelo Comitê: nos valores unitários de diluição e de captação pelo uso da água; na decisão do regime de vazão de referência adotado e condicionado a uma determinada garantia; na Classe de Uso do corpo hídrico ou mesmo em metas de escalonamento para atendimento a uma determinada Classe de Uso; na própria revisão do Plano de Recursos Hídricos. Todas estas decisões influenciam o montante de dinheiro arrecadado na bacia através da cobrança e, conseqüentemente, nas metas estabelecidas nos Planos de Recursos Hídricos.

Os valores unitários adotados para diluição refletem-se direta e proporcionalmente no custo de lançamento, enquanto os valores unitários adotados para a captação refletem diretamente no custo de captação quando não levada em consideração a qualidade da água captada. Nos cálculos realizados pelo SSD RB, através do modelo RM1, considerando a qualidade da água captada, o custo de captação é inversamente proporcional à qualidade da água, sendo também condicionado ao custo unitário da vazão de diluição.

A decisão do enquadramento do corpo hídrico em sua respectiva Classe de Uso também deve ser tomada com base nas vazões que serão disponibilizadas naquele corpo para outorga, nos custos unitários de captação e lançamento, assim como nos valores cobrados dos usuários da bacia e o conseqüente montante arrecadado.

Através das simulações realizadas com o SSD RB, verifica-se que o custo de captação independe da Classe de Uso quando não é levada em consideração a qualidade da água captada. Considerando-se esta, o custo cai quanto mais degradada for a qualidade da água, assim como o custo também cai quanto mais restritiva for a Classe de Uso, devido à maior vazão de diluição da carga de poluente retirada do rio.

A Classe de Uso também influencia na vazão liberada para outorga, ou seja, quanto mais restritiva for a Classe de Uso, diante de um mesmo regime de vazão de referência e de um mesmo cenário de lançamentos e captações, menor será a vazão liberada ao longo do corpo hídrico para outorga, devido à menor concentração de poluente exigida no corpo hídrico para atendimento da respectiva Classe de Uso. Logo, a decisão pela 
escolha da Classe de Uso de um corpo hídrico deve também estar apoiada nos respectivos usos da bacia, assim como no seu planejamento econômico e ambiental.

No sistema desenvolvido, são admitidos 20 cenários de vazão, pois assim possibilita-se a análise da outorga de direito ao uso da água condicionada a uma garantia hidrológica. Cenários de vazão $\mathrm{Q}_{7,10}, \mathrm{Q}_{95}, \mathrm{Q}_{90}$ e Qm, como os aplicados no estudo de caso do SSD $\mathrm{RB}$, podem ser utilizados, assim como diferentes regimes de vazão associados a cada mês do ano, levando-se em conta a sazonalidade ou mesmo vazões liberadas por reservatórios.

Mas ressalte-se que o SSD RB permite a realização de diversos cenários, combinados entre dados hidráulicos, dados de cabeceira, dados de condição inicial do rio, poluição difusa, parâmetros e coeficientes, custos unitários e classe de uso, facilitando o processo de calibração do sistema e permitindo um maior controle da relação causa $\mathrm{x}$ efeito dos fatores envolvidos na gestão de uma bacia hidrográfica.

A combinação entre cenários, através do SSD RB, é possível porque em um único arquivo de entrada de dados do sistema, para cada cenário, é inserido um conjunto de dados pertinente ao mesmo. Quando o usuário clica no botão "rodar" do sistema, os cálculos realizados pelos modelos RM1 e QUAL2E são realizados distintamente para cada cenário, possibilitando, na saída do sistema, uma análise comparativa entre os resultados obtidos para cada cenário simulado, permitindo assim, um maior controle da relação causa x efeito dos fatores envolvidos na gestão de uma bacia hidrográfica.

A escolha de uma vazão de referência para a outorga, ou de múltiplas vazões de referência associadas às suas respectivas garantias, deve estar apoiada no fato de que, diante de um mesmo cenário de lançamentos e captações, quanto menor a vazão, maior a concentração de poluente no corpo hídrico, logo, menor a vazão liberada ao longo do rio para outras outorgas e também maior o custo da vazão de diluição da carga de poluente retirada do rio através de captação; com isto, menor o custo de captação e maior o custo de lançamento.

Através da aplicação do SSD RB também se verifica, fixando os custos unitários de captação e lançamento, que a adoção de Classe de Uso e de vazão de referência mais 
restritivas encarecem o custo de lançamento (quando este influencia captações de jusante) e reduz a vazão liberada para outorga, conferindo um valor monetário menor arrecadado na bacia.

Em situação de escassez, para o cumprimento à legislação ambiental, nem todos os usuários da bacia poderão ser atendidos, seja de captação ou de lançamento. Dentro desta situação de racionamento, a decisão de quais usuários terão prioridade de atendimento é uma decisão para ser tomada no âmbito do Comitê. Fica aqui a sugestão de adoção de custos unitários para a diluição e para a captação maiores, em função do número máximo de usuários que estarão dispostos a pagar e, principalmente, em função do atendimento à legislação ambiental. Quando ao ressarcimento dos usuários prejudicados, isto também pode ficar a critério do Comitê de Bacia ou da autoridade competente.

O SSD RB permite também fazer uma análise do quanto uma retirada expressiva de água do corpo hídrico pode afetar sua capacidade de diluição e liberação de vazão para outorga, isto tanto em termos de quantidade e qualidade da água como em termos de custos de lançamento e captação, permitindo uma análise mais criteriosa para a liberação de outorga.

Como exposto acima, o SSD RB pode contribuir para o gerenciamento da demanda, assim como para a decisão da localização espacial da atividade econômica, tanto dentro de uma bacia como fora da mesma. O estudo da localização de uma indústria em uma bacia pode ser feito considerando a quantidade e a qualidade da água de captação, associada ao respectivo custo, assim como o custo de lançamento associado aos prejuízos ocasionados aos usuários de jusante.

Dessa forma, o SSD RB pode também contribuir para o ordenamento espacial da atividade econômica, através de estímulo de preços mais confortáveis para regiões e bacias hidrográficas menos densas, podendo contribuir para a distribuição de atividades econômicas de forma mais homogênea. 
Assim fica clara a importância do SSD RB como ferramenta de auxílio na gestão qualiquantitativa dos processos de outorga e cobrança pelo uso da água, visando água de boa qualidade para múltiplos usos.

Finalmente, conclui-se que para o sucesso da aplicação do sistema aqui desenvolvido, é necessária a articulação de todos os instrumentos da Política Nacional de Recursos Hídricos, dentro da diretriz de gestão integrada de recursos hídricos, assim como é necessário também que os Planos de Recursos Hídricos estejam apoiados em programas de desenvolvimento, conservação e reversão da poluição, promovendo o equilíbrio entre o desenvolvimento social e econômico. Para isto existe a necessidade, no processo de gestão de recursos hídricos, de regras claras e consistentes, que levem em consideração as peculiaridades de cada bacia, para enfrentar os possíveis conflitos gerados pelo uso da água. Isto evidencia a importância do sistema de gestão de recursos hídricos ser descentralizado, integrado, participativo e, sobretudo, transparente.

\subsection{Recomendações}

Ressalte-se aqui a importância da Resolução ${ }^{\circ}$ 48, de 21 de março de 2005, e da Resolução $\mathrm{n}^{\circ}$ 357, de 17 de março de 2005, adotarem o conceito de Justiça Hídrica, conforme criado de forma inovadora no presente trabalho, ou seja, quem capta água com qualidade superior paga mais do que quem capta água com qualidade inferior, assim como, quem mais polui e prejudica os usuários de jusante, mais paga, tornando o sistema de gestão muito mais racional e justo.

Como já exposto neste trabalho, o Sistema de Informações de Recursos Hídricos deve conter informações confiáveis da bacia hidrográfica e da região em estudo para a alimentação do sistema, possibilitando que o planejamento e o gerenciamento de recursos hídricos sejam exercidos de forma consistente e eficaz. Logo, recomenda-se que as redes de monitoramento de qualidade e de quantidade da água sejam estruturadas e operadas visando a gestão integrada de recursos hídricos e o uso de modelos de simulação de qualidade da água.

A disposição de pontos de monitoramento na bacia hidrográfica e a escolha das variáveis a serem monitoradas devem ser realizadas de forma criteriosa, estando 
apoiadas nos usos da bacia e nos diagnósticos e prognósticos de atendimento as metas estabelecidas nos Planos de Recursos Hídricos.

O monitoramento deve ser sistemático e articulado. A rede de monitoramento de qualidade da água deve ser, de preferência, combinada com a rede de monitoramento hidrológica, ou seja, a localização de postos fluviométricos deve ser combinada sempre que possível com a localização de postos de qualidade da água. A data de coleta das amostras deve ser sistemática e, preferencialmente, combinada com a data e horário da medida de vazão ou de nível. A exclusão ou mudança de um ponto de monitoramento da rede deve ser realizada de forma criteriosa, porque esta atitude implica não apenas em dados que deixaram de ser medidos no ponto, mas sobretudo na perda de uma série histórica da rede.

Recomenda-se aqui que as metodologias de outorga e cobrança sejam apoiadas, tanto quanto possível, na realidade física do corpo hídrico e nos seus processos envolvidos. Assim, o sistema de gestão estará mais próximo da efetiva aplicação da Política Nacional de Recursos Hídricos.

Note-se que no Brasil, atualmente, as redes de monitoramento muitas vezes apresentam deficiências, inviabilizando o uso de modelos matemáticos mais sofisticados que requerem uma quantidade muito grande de dados de entrada, por isso, recomenda-se o uso de modelos que adotem maior simplicidade, mas que nem por isso deixem de oferecer subsídios para uma tomada de decisão mais próxima da realidade através de uma alocação de recursos mais eficiente como, por exemplo, o uso do sistema apresentado neste trabalho.

É melhor ter o domínio de um modelo que requer uma pequena quantidade de parâmetros de calibração, tendo controle da relação causa $\mathrm{x}$ efeito das variáveis envolvidas, do que ter um modelo mais sofisticado que requer uma quantidade muito grande de parâmetros de calibração, muitas vezes associado à falta de controle da relação causa $\mathrm{x}$ efeito, tanto devido às incertezas e inexistência de dados de entrada como do próprio domínio pelo usuário da ferramenta utilizada. 
Recomenda-se também que não apenas as pessoas que operem o sistema de outorga e cobrança tenham conhecimento dos conceitos envolvidos na alocação dos recursos hídricos, mas sim todos os envolvidos no processo de gestão de uma bacia hidrográfica. Para tanto é necessária a difusão destes conceitos.

Quanto ao SSD RB, este pode se tornar mais amigável através dos recursos que vêm sendo oferecidos pela informática como, por exemplo, o uso de ferramentas que permitem a disposição georeferenciada dos pontos de captação e lançamento. A base de dados do SSD RB também pode ser acoplada à base de dados do Sistema Nacional de Informações de Recursos Hídricos. Outros modelos também podem ser inseridos no SSD RB como, por exemplo, o modelo RM2 (RODRIGUES, 2003) que contabiliza a carga de poluente que sedimenta no corpo hídrico para cada usuário-poluidor, ao longo do espaço e do tempo. O modelo RM1 trabalha com a carga de poluente em suspensão no corpo hídrico, não considerando a carga que é sedimentada para cobrança.

Note-se que no SSD RB, poderá ser inserida uma grande variedade de modelos, que vão desde modelos de operação de reservatório a modelos tridimensionais de qualidade da água e modelos ecológicos. Mas observa-se que a relação benefício-custo deve ser ponderada, assim como o grau de compreensão destas ferramentas pelos possíveis usuários. O sistema de gestão de outorga e cobrança não deve ser simples o bastante a ponto de se distanciar da realidade física do corpo hídrico e dos processos envolvidos, o que o faz se distanciar da própria aplicação da Política Nacional de Recursos Hídricos, assim como não deve ser complexo o bastante a ponto de causar repulsa por parte dos possíveis usuários do sistema e, sobretudo, fugindo da compreensão da grande maioria dos envolvidos no processo de gestão de uma bacia hidrográfica.

Para a próxima versão do SSD RB, versão 1.01, recomenda-se que seja inserida a variável alga, visando à simulação de trechos de reservatórios.

A versão 1.00, do SSD RB, apresenta as mesmas limitações computacionais do modelo QUAL2E, na versão 3.22, de maio de 1996. Recomenda-se que estas limitações sejam contornadas no código fonte do modelo QUAL2E. 
Recomenda-se que, na próxima versão do SSD RB seja inserida uma metodologia que diferencie trechos de rios que apresentem reservatórios como, por exemplo, o rio Tietê no Estado de São Paulo, porque nestes trechos, como regra geral, a vazão afluente é diferente da vazão liberada pelo reservatório, o que compromete a aplicação do modelo QUAL2E que trabalha com o balanço hídrico em rios.

Como já dito, o SSD RB permite também fazer uma análise do quanto uma retirada expressiva de água do corpo hídrico pode afetar sua capacidade de diluição e liberação de vazão para outorga, isto tanto em termos de quantidade e qualidade da água como em termos de custos de lançamento e captação, permitindo uma análise mais criteriosa para a liberação de outorga. Para lançamento, o sistema contabiliza financeiramente os danos, em termos de qualidade da água, aos usuários de jusante. Recomenda-se que isto também seja feito para a captação, considerando os usuários de jusante e de montante, e repassado ao respectivo usuário. Os cálculos realizados pelo modelo RM1 possibilitam isto, existe, agora, a necessidade de criação de rotinas de programação no SSD RB.

Recomenda-se que seja desenvolvida no SSD RB uma variável que sintetize o grau de prejuízo de um lançamento ou de uma captação aos respectivos usuários atingidos, auxiliando dessa forma no processo de decisão. 


\section{REFERÊNCIAS BIBLIOGRÁFICAS}

\section{Referências bibliográficas consultadas e citadas no texto}

ALMEIDA, C. N.; BRAGA, A. C; ROSA, M. S. M. O sistema de gestão de outorgas do Estado da Paraíba. In: XV SIMPÓSIO BRASILEIRO DE RECURSOS HÍDRICOS, Paraná-Curitiba, 23 a 27, dez/2003. Anais do XV Simpósio Brasileiro de Recursos Hídricos. Tema: Desafios à Gestão da Água no Limiar do Século XXI. São Paulo: ABRH, 2003.

AZEVEDO, L. G.; BALTAR, A. M.; FREITAS, P. A experiência internacional. In: $A$ cobrança pelo uso da água. Coordenação e organização científica: THAME, A. C. São Paulo: IQUAL, Instituto de Qualificação, LTDA, 2000. p. 19-27.

BALTAR, A. M.; CORDEIRO, O. M. Sistema de apoio a decisão para avaliação econômica da alocação de recursos hídricos. In: XV SIMPÓSIO BRASILEIRO DE RECURSOS HÍDRICOS, Aracaju-SE, 25 a 29, nov/2001. Anais do XIV Simpósio Brasileiro de Recursos Hídricos. Tema: Gestão de Recursos Hídricos: O Desafio da Prática. São Paulo: ABRH, 2001.

BARROS, M. T.; PORTO, M.; BRANDÃO, J. L. B.; HAMBURGER, D. S.; ONO, S. Sistema de suporte ao gerenciamento da água urbana. In: XV SIMPÓSIO BRASILEIRO DE RECURSOS HÍDRICOS, Paraná-Curitiba, 23 a 27, dez/2003. Anais do XV Simpósio Brasileiro de Recursos Hídricos. Tema: Desafios à Gestão da Água no Limiar do Século XXI. São Paulo: ABRH, 2003.

BENN, F. R. e Mc. AULIFFE, C. A Química e Poluição. Tradução por PITOMBO, L. R. M. e MASSARO, S. Rio de Janeiro, 1981. Tradução de "Chemistry and Pollution". BRANCO, M. A; CORDEIRO, O. M. O FEHIDRO e a participação social na gestão das águas no Estado de São Paulo. In: XV SIMPÓSIO BRASILEIRO DE RECURSOS HÍDRICOS, Paraná-Curitiba, 23 a 27, dez/2003. Anais do XV Simpósio Brasileiro de Recursos Hídricos. Tema: Desafios à Gestão da Água no Limiar do Século XXI. São Paulo: ABRH, 2003. 
BRASIL. CONAMA, Conselho Nacional do Meio Ambiente, Resoluções do CONAMA. Brasília, D.F.: SEMA, 1988. 98p.

BRASIL. CONAMA, Conselho Nacional do Meio Ambiente, Resolução n 357, de 17 de março de 2005.

BRASIL. Decreto e portaria de outorga e fiscalização. Decreto $\mathrm{n}^{\circ} 41.258$ e Portaria DAEE nº 717 de 12-12-96. São Paulo, 1995.

BRASIL. Decreto Estadual 8.468 de 8 de setembro de 1976. Regulamenta a Lei Estadual $n^{\circ}$ 997, que dispõe sobre a Prevenção e o Controle da Poluição do Meio Ambiente.

BRASIL. Deliberação CEIVAP $n^{\circ} 03 / 2001$ de 8 de setembro de 2001. Aprova a Implantação da Cobrança pelo Uso de Recursos Hídricos de Domínio da União na Bacia do Rio Paraíba do Sul a partir de 2002 e estabelece as condições para a sua participação no Programa Nacional de Despoluição de Bacias Hidrográficas.

BRASIL. Deliberação CEIVAP n 08/2001 de 6 de dezembro de 2001. Apresenta a formulação de cobrança instituída pelo CEIVAP na Bacia do Rio Paraíba do Sul.

BRASIL. Lei Federal n. 9.433 de 08 de janeiro de 1997. Institui a Política e Sistema Nacional de Gerenciamento de Recursos Hídricos.

BRASIL. Lei 7.663 de 30 de dezembro de 1991. Instituiu a Política Estadual de Recursos Hídricos e o Sistema Integrado de Gerenciamento de Recursos Hídricos, no Estado de São Paulo.

BRASIL. Projeto de Lei 676/00. São Paulo, 2000. Projeto de Lei em discussão na Assembléia Legislativa.

BRASIL. Projeto de Lei, PLS 240/02. Estabelece que os valores arrecadados com a cobrança pelo uso de recursos hídricos e com a aplicação de multas na bacia em que foram gerados sejam aplicados integralmente na mesma bacia. Outubro de 2004. 
BRASIL. Resolução $n^{\circ} 16$ do Conselho Nacional de Recursos Hídricos (CNRH), de 08 de maio de 2001 .

BRASIL. Resolução n ${ }^{\circ} 48$ do Conselho Nacional de Recursos Hídricos (CNRH), de 21 de março de 2005. Estabelece critérios gerais para a cobrança pelo uso dos recursos hídricos.

CRH, Conselho Estadual de Recursos Hídricos. Simulação da cobrança pelo uso da água. Versão preliminar de 31/07/97. São Paulo: CRH, 1997.

BROWN, L. C.; BARNWELL Jr., T.O. Computer program documentation for the enhanced stream water quality model QUAL2E. and QUAL2E-UNCAS. Report EPA/600/3-87/007, US Enviromental Protection Agency, Athens, Georgia, USA, 1987.

CARVAlHO, M. A.; SCHARDONG, A.; JÚNIOR, A. V. M.; PORTO, L. L. R. Sistema de suporte a decisão para alocação de água em projetos de irrigação. In: XV SIMPÓSIO BRASILEIRO DE RECURSOS HÍDRICOS, Paraná-Curitiba, 23 a 27, dez/2003. Anais do XV Simpósio Brasileiro de Recursos Hídricos. Tema: Desafios à Gestão da Água no Limiar do Século XXI. São Paulo: ABRH, 2003.

CASTEllo, N. E.; RODRIGUES, R. B.; PERCINOTTI, C.; ARANHA, C. H.; NETO, A. S. B.; NETO, J. C. Apresentação da rede de monitoramento da qualidade das águas na Região do Alto Tietê e resultados preliminares obtidos para a avaliação dos benefícios advindos da $2^{\mathrm{a}}$. Etapa do Projeto Tietê. In: XV SIMPÓSIO BRASILEIRO DE RECURSOS HÍDRICOS, Paraná-Curitiba, 23 a 27, dez/2003. Anais do XV Simpósio Brasileiro de Recursos Hídricos. Tema: Desafios à Gestão da Água no Limiar do Século XXI. São Paulo: ABRH, 2003.

CASTRO, H. L.; PORTO, R. L. Avaliação da disponibilidade hídrica para abastecimento da Região Metropolitana de São Paulo com o uso de um sistema de suporte a decisões. In: XV SIMPÓSIO BRASILEIRO DE RECURSOS HÍDRICOS, Paraná-Curitiba, 23 a 27, dez/2003. Anais do XV Simpósio Brasileiro de Recursos Hídricos. Tema: Desafios à Gestão da Água no Limiar do Século XXI. São Paulo: ABRH, 2003. 
CETESB, Companhia de Tecnologia de Saneamento Ambiental. Controle de poluição das águas - Bacia do Rio Jundiaí, 1981.

CETESB. Dados de captações e lançamentos urbanos e industriais. São Paulo: CETESB de Jundiaí, 1996. (dados não publicados).

CETESB. Relatórios de qualidade das águas interiores do Estado de São Paulo, 1978 a 1997. CETESB, 1978 a 2003.

CHAPRA, S.C. Surface water quality modeling. Colorado, USA: MacGraw-Hill, 1997. 843 p.

CONEJO, J. G. L. Considerações sobre a formulação de preços para a cobrança pelo uso da água no Brasil. In: O sistema de cobrança no Estado de São Paulo. Coordenação e organização científica: THAME, A. C. São Paulo: IQUAL, Instituto de Qualificação, LTDA, 2000. p. 127-134.

COSTA, M. P.; SILVA, L. H. P.; BUBEL, A. P. M.; BRANDÃO, V. S.; ACSELRAD, M. V. Proposta de enquadramento dos corpos d'água da bacia do rio São Francisco. In: VII SIMPÓSIO DE RECURSOS HÍDRICOS DO NORDESTE, São Luís-MA, 30 nov a $03 \mathrm{dez}, 2004$. Anais do VI Simpósio de Recursos Hídricos do Nordeste. Tema: Gestão democrática e sustentável das águas. São Paulo: ABRH, 2004.

CRUZ, J. C.; SILVEIRA, G. L.; SILVEIRA, A. L. L.; CRUZ, R. C. Disponibilidade hídrica para outorga: sistemática modular de avaliação. In: XV SIMPÓSIO BRASILEIRO DE RECURSOS HÍDRICOS, Paraná-Curitiba, 23 a 27, dez/2003. Anais do XV Simpósio Brasileiro de Recursos Hídricos. Tema: Desafios à Gestão da Água no Limiar do Século XXI. São Paulo: ABRH, 2003.

FIGUEIREDO, L. C.; RUBERT, O. A. Processo de análise para concessão de outorga do direito de uso de águas superficiais. In: XV SIMPÓSIO BRASILEIRO DE RECURSOS HÍDRICOS, Aracaju-SE, 25 a 29, nov/2001. Anais do XIV Simpósio Brasileiro de Recursos Hídricos. Tema: Gestão de Recursos Hídricos: O Desafio da Prática. São Paulo: ABRH, 2001. 
FOLHA DE SÃO PAULO. SP 'transborda' e faz vizinhos 'incharem'. Folha de São Paulo. São Paulo: Jornal Folha de São Paulo, 3 mar. 1997. Caderno 3, p. 11.

GARRIDO, R. Considerações sobre a formulação de preços para a cobrança pelo uso da água no Brasil. In: A cobrança pelo uso da água. Coordenação e organização científica: THAME, A. C. São Paulo: IQUAL, Instituto de Qualificação, LTDA, 2000. p. 57-91.

KELMAN, J. Gerenciamento de recursos hídricos parte I: outorga. In: XII SIMPÓSIO BRASILEIRO DE RECURSOS HÍDRICOS, 1997, Vitória, ES., 16-20, nov., 1997. Anais do XII Simpósio Brasileiro de Recursos hídricos. Tema: Bases técnicas para a implementação dos sistemas de gestão de recursos hídricos. São Paulo: ABRH, 1997. v.1 p. 123-128.

KELMAN, J. Gerenciamento de recursos hídricos parte II: cobrança. In: XII SIMPÓSIO BRASILEIRO DE RECURSOS HÍDRICOS, 1997, Vitória, ES., 16-20, nov., 1997. Anais do XII Simpósio Brasileiro de Recursos hídricos. Tema: Bases técnicas para a implementação dos sistemas de gestão de recursos hídricos. São Paulo: ABRH, 1997. v.1 p. 129-136.

HAASE, J. F.; SILVA, M. L. Enquadramento das águas do rio dos sinos - um processo participativo. In: XV SIMPÓSIO BRASILEIRO DE RECURSOS HÍDRICOS, ParanáCuritiba, 23 a 27, dez/2003. Anais do XV Simpósio Brasileiro de Recursos Hídricos. Tema: Desafios à Gestão da Água no Limiar do Século XXI. São Paulo: ABRH, 2003.

IBGE. MINISTÉRIO DO PLANEJAMENTO E COORDENAÇÃO GERAL. SUPERINTENDENCIA DE CARTOGRAFIA. Região Sudeste do Brasil. Folhas: Campo Limpo, Jundiaí, Indaiatuba, Salto. Escala: 1: 50.000, 1973.

LORDÊllo, A. V.; CARDOSO, E. R.; SILVA, F. F.; TEIXEIRA, M. J. Gerenciamento das outorgas no Estado da Bahia. In: XV SIMPÓSIO BRASILEIRO DE RECURSOS HÍDRICOS, Paraná-Curitiba, 23 a 27, dez/2003. Anais do XV Simpósio Brasileiro de Recursos Hídricos. Tema: Desafios à Gestão da Água no Limiar do Século XXI. São Paulo: ABRH, 2003. 
MACRIS, V. A legislação estadual. In: A cobrança pelo uso da água. Coordenação e organização científica: THAME, A. C. São Paulo: IQUAL, Instituto de Qualificação, LTDA, 2000. p. 35-39.

MEDEIROS, Y. D.; SILVA, E. R.; CORTIZO, C. S; SHAER, M. Sistema de apoio a decisão - SAD - para análise e controle de pleito de outorga de água na bacia do rio Jacuípe - BAHIA. In: XV SIMPÓSIO BRASILEIRO DE RECURSOS HÍDRICOS, Aracaju-SE, 25 a 29, nov/2001. Anais do XIV Simpósio Brasileiro de Recursos Hídricos. Tema: Gestão de Recursos Hídricos: O Desafio da Prática. São Paulo: ABRH, 2001.

PORTO, M. Sistemas de Gestão da Qualidade das Águas: Uma Proposta para o Caso Brasileiro. São Paulo, 2002. 131p. Tese (Livre Docência). Escola Politécnica da Universidade de São Paulo - Departamento de Engenharia Hidráulica e Sanitária.

PORTO, M. Comunicação pessoal. Professora do Departamento de Hidráulica e Saneamento da EPUSP, 2001.

PORTO, M. Material de Aula da Disciplina Qualidade da Água, PHD - 5004. São Paulo: Escola Politécnica da Universidade de São Paulo - Departamento de Engenharia Hidráulica e Sanitária, 1997.

PORTO, R. L.; AZEVEDO, L. G. Sistemas de suporte a decisões aplicados a problemas de recursos hídricos. In: Técnicas quantitativas para o gerenciamento de recursos hídricos. Coordenação e organização científica: PORTO, R. L. Porto Alegre: Ed. da Universidade/UFSGS/ABRH, 1997 (Coleção ABRH de recursos hídricos). p. 42-95.

ROBERTO, A. N. Modelos de rede de fluxo para alocação da água entre múltiplos usos em uma bacia hidrográfica. São Paulo, 2002. 105p. Dissertação (Mestrado). Escola Politécnica da Universidade de São Paulo - Departamento de Engenharia Hidráulica e Sanitária. 
RODRIGUES, R. B. Metodologia de apoio à concessão de outorga para lançamento de efluentes e cobrança pelo uso da água - O modelo RM1. São Paulo, 2000. 140p. Dissertação (Mestrado). Escola Politécnica da Universidade de São Paulo Departamento de Engenharia Hidráulica e Sanitária.

RODRIGUES, R. B. Modelagem dos poluentes orgânicos em corpos d'água superficiais. In: Esgoto Sanitário: coleta, transporte, tratamento e reuso agrícola. NUVOLARI, A. (coordenador). FATEC-SP/CEETEPS. São Paulo, 2003. Editora Edgard Blucher LTDA. 209-226p.

RODRIGUES, R. B. ; PORTO, M. Interface proposta para o modelo QUAL2E visando a gestão integrada de recursos hídricos. In: XV SIMPÓSIO BRASILEIRO DE RECURSOS HÍDRICOS, Paraná-Curitiba, 23 a 27, dez/2003. Anais do XV Simpósio Brasileiro de Recursos Hídricos. Tema: Desafios à Gestão da Água no Limiar do Século XXI. São Paulo: ABRH, 2003.

SANTOS, M. R.; KELMAN, J. A experiência européia e brasileira na cobrança pelo uso da água. In: XV SIMPÓSIO BRASILEIRO DE RECURSOS HÍDRICOS, ParanáCuritiba, 23 a 27, dez/2003. Anais do XV Simpósio Brasileiro de Recursos Hídricos. Tema: Desafios à Gestão da Água no Limiar do Século XXI. São Paulo: ABRH, 2003.

SECRETARIA DE RECURSOS HÍDRICOS, SANEAMENTO E OBRAS. Banco de Dados Fluviométricos do Estado de São Paulo (Atualizados até 1997). Elaborado por Fundação Centro Tecnológico de Hidráulica - FCTH. Convênio DAEE - USP, 1999. SECRETARIA DE RECURSOS HÍDRICOS, SANEAMENTO E OBRAS. Banco de Dados Pluviométricos do Estado de São Paulo (Atualizados até 1997). Elaborado por Fundação Centro Tecnológico de Hidráulica - FCTH. Convênio DAEE - USP, 1999.

SOUSA, Jr. W. Gestão participativa e cobrança pelo uso da água: o caso do CEIVAP. In: XV SIMPÓSIO BRASILEIRO DE RECURSOS HÍDRICOS, Paraná-Curitiba, 23 a 27, dez/2003. Anais do XV Simpósio Brasileiro de Recursos Hídricos. Tema: Desafios à Gestão da Água no Limiar do Século XXI. São Paulo: ABRH, 2003. 
STREETER, H.W.; PHELPS, E.B. A study of the natural purification of the Ohio River. Public Health Bulletin 146, U.S. Public Health Survice, Washington, 1925.

TCHOBANOGLOUS, G.; SCHROEDER, E. D. Water quality. California, USA: Addison-Wesley, 1985. 768 p.

TEXEIRA, C. A; SCHARDONG, A.; PORTO, R. L. QualidadeCLS: um modelo para a determinação das concentrações dos parâmetros de qualidade de águas em rios. In: XV SIMPÓSIO BRASILEIRO DE RECURSOS HÍDRICOS, Paraná-Curitiba, 23 a 27, dez/2003. Anais do XV Simpósio Brasileiro de Recursos Hídricos. Tema: Desafios à Gestão da Água no Limiar do Século XXI. São Paulo: ABRH, 2003.

THAME, A. C. Fundamentos e Antecedentes. In: A cobrança pelo uso da água. Coordenação e organização científica: THAME, A. C. São Paulo: IQUAL, Instituto de Qualificação, LTDA, 2000. p. 11-16.

ThOMAS, P.; MAGAlhãeS, P. C.; AZEVEDO, J. P. S. Proposta de uma metodologia de cobrança pelo uso da água vinculada à escassez. In: XV SIMPÓSIO BRASILEIRO DE RECURSOS HÍDRICOS, Paraná-Curitiba, 23 a 27, dez/2003. Anais do XV Simpósio Brasileiro de Recursos Hídricos. Tema: Desafios à Gestão da Água no Limiar do Século XXI. São Paulo: ABRH, 2003.

UNEP, United Nations Environmental Programme. "Water Quality of World River Basins”. UNEP Environment Library. n. 14. Nairobi, Kenya, 39 p. 1995.

USEPA, United Sates Environmental Protection Agency. "QUAL2E Windows Interface User's Guide". Report nEPA/823/B/95/003. Environmental Research Laboratory, setembro de 1995.

\section{Sites}

http://www.ana.gov.br

http://www.brasildasaguas.com.br

http://www.rbrecursoshidricos.com

http://www.sabesp.com.br 


\section{Referências bibliográficas consultadas}

ANA. Plano Nacional de Recursos Hidricos. Agência Nacional de Águas. Brasília-DF, novembro de 2003.

ANA. Relatório de Gestão 2003. Agência Nacional de Águas. Brasília- DF, 2003.

BANCO MUNDIAL. Gerenciamento de Recursos Hídricos. Coordenação e organização científica: RODRIGUEZ, F. A.; tradução de Henrique Chaves. Brasília: Secretaria de Recursos Hídricos, 1998. 292p.

CBH-PCJ, Comitê das Bacias Hidrográficas dos Rios Piraciba, Capivari e Jundiaí, Relatório de Situação dos Recursos Hídricos 1993, São Paulo: CBH-PCJ, abr. 1994.

CBH-PCJ, Comitê das Bacias Hidrográficas dos Rios Piracibaca, Capivari e Jundiaí, Uma história de amor pelas águas, São Paulo: CBH-PCJ, dez. 1998. (Edição especial do Comitê das Águas: órgão informativo do Comitê das Bacias Hidrográficas do Rios Piracicaba, Capivari e Jundiaí).

CBH-PCJ. Informações técnicas SAM / 004 / 87. Coletas de Amostras de Água para Análises - Rio Jundiaí, 1987.

CHAPRA, S. C.; RUNKEL, R. L. Modeling impact of storage zones on stream dissolved oxygen. Journal of environmental engineering. v. 125. n. 5. p. 415-419, maio 1999.

DAEE, Departamento de Águas e Energia Elétrica do Estado de São Paulo. Determinação expedita do coeficiente de rugosidade e da curva-chave nos Rios Sorocaba e Jundiaí, 1979. São Paulo: DAEE, set. 1979.

EIGER, S. Apostila da disciplina: Dispersão de poluentes em rios e estuários, PHD 735. São Paulo: Escola Politécnica da Universidade de São Paulo - Departamento de Engenharia Hidráulica e Sanitária, 1997. 
EIGER, S. Qualidade da água em rios e estuários. In: PORTO, R. L., org. Hidrologia ambiental. São Paulo: EDUSP/ABRH, 1991. p. 69-163. (Coleção ABRH de recursos hídricos; v.3)

FERRAZ, A.R.G. ; BRAGA JR., B.P.F. Modelo decisório para a outorga de direito ao uso da água no Estado de São Paulo. Revista Brasileira de Recursos Hídricos - RBRH, v. 3, n. 1, p. 5-19, jan./mar. 1998.

FISCHER, H. B. et al. Mixing in inland and coastal waters. New York: Academic Press, Inc., 1979. 483p.

LIMA, C.A.A. O uso do modelo QUAL2E na simulação da qualidade das águas do Rio Jacaré-Guaçu. São Carlos, 1997. 179p. Dissertação (Mestrado). Escola de Engenharia de São Carlos, Universidade de São Paulo.

MAIDMENT, D. R. Handbook of Hydrology. New York: McGraw-Hill, 1993. (várias paginações).

MARTINEZ JR., F. Aplicação de instrumentos econômicos à gestão ambiental Introdução da cobrança pela utilização dos recursos hídricos no Estado de São Paulo, 1997. 253p. Tese (Doutorado). Escola Politécnica da Universidade de São Paulo Departamento de Engenharia Hidráulica e Sanitária.

METCALF \& EDDY, Co. Wastewater enginnering: treatment, disposal, and reuse. rev. THOBANOGLOUS, G. and BURTON, F. L. 3. ed. New York: McGraw-Hill, 1991. 1334p. (MacGraw-Hill series in water resources and environmental engineering)

MELCHING, C. M.; FLORES, H. E. Reaeration equations derived from U.S. Geological Survey Database. Journal of environmental engineering. v. 125. n. 5. p. 407414, maio 1999.

PEREIRA, J. S.; LANNA, A.E.; CÁNEPA, E.M. Desenvolvimento de um sistema de apoio à Cobrança pelo uso da água; aplicação à Bacia dos Sinos, RS. Revista Brasileira de Recursos Hídricos - RBRH, v. 4, n. 1, p. 77-101, jan./mar. 1999. 
PORTO, R. L. (org.). Técnicas quantitativas para o gerenciamento de recursos hídricos. Porto Alegre: Ed. da Universidade/UFSGS/ABRH, 1997. 420p. (Coleção ABRH de recursos hídricos).

RODRIGUES, R. B.; PORTO, M. Análise Comparativa de Metodologias de Apoio para os Processos de Concessão de Outorga para Lançamento de Efluentes e Cobrança pelo Uso da Água. In: XIV SIMPÓSIO BRASILEIRO DE RECURSOS HÍDRICOS e do V SIMPÓSIO DE HIDRÁULICA E RECURSOS HÍDRICOS DOS PAÍSES DE LÍNGUA OFICIAL PORTUGUESA, SE., 25-29, nov./2001. Tema: gestão de recursos hídricos: o desafio da prática. São Paulo: ABRH/APRH, 2001.

RODRIGUES, R. B.; PORTO, M. Modelo matemático proposto para auxílio nos processos de outorga e cobrança pelo uso da água. In: XIII SIMPÓSIO BRASILEIRO DE RECURSOS HÍDRICOS, 1999, Belo Horizonte, MG., 28-02, nov./dez., 1999. Anais do XIII Simpósio Brasileiro de Recursos Hídricos.

RODRIGUES, R. B.; PORTO, M. Modelagem do sistema de suporte a decisão QUAL2R-2 para os processos de outorga e cobrança pelo uso da água - Integração dos modelos QUAL2E, RM1 e MODSIMP32. In: XIV SIMPÓSIO BRASILEIRO DE RECURSOS HÍDRICOS e do V SIMPÓSIO DE HIDRÁULICA E RECURSOS HÍDRICOS DOS PAÍSES DE LÍNGUA OFICIAL PORTUGUESA, SE., 25-29, nov./2001. Tema: gestão de recursos hídricos: o desafio da prática. São Paulo: ABRH/APRH, 2001.

RODRIGUES, R. B.; PORTO, M. Modelo matemático proposto para quantificação da massa de poluentes em rios - Modelo RM2. In: XIV SIMPÓSIO BRASILEIRO DE RECURSOS HÍDRICOS e do V SIMPÓSIO DE HIDRÁULICA E RECURSOS HÍDRICOS DOS PAÍSES DE LÍNGUA OFICIAL PORTUGUESA, SE., 25-29, nov./2001. Anais do XIV Simpósio Brasileiro de Recursos Hídricos e V Simpósio de Hidráulica e Recursos Hídricos dos Países de Língua Oficial Portuguesa. Tema: gestão de recursos hídricos: o desafio da prática. São Paulo: ABRH/APRH, 2001. 
SANEAMENTO AMBIENTAL. Bacia do Rio Jundiaí - Nova ETE viabiliza futuro mais promissor. Revista Saneamento Ambiental. São Paulo, n. 53, p. 42-44, set./out. 1998.

SECRETARIA DE RECURSOS HÍDRICOS, SANEAMENTO E OBRAS. Programa de Investimentos para Proteção e Aproveitamento dos Recursos Hídricos das Bacias dos Rios Piracicaba, Capivari e Jundiaí. Consórcio Figueiredo Ferraz - COPLASA, abril de 1999.

SIQUEIRA, E. Q. Aplicação do modelo de qualidade de água (QUAL2E) na modelação de oxigênio dissolvido no Rio Meia Ponte (GO), 1996. 90p. Dissertação (Mestrado). Escola de Engenharia de São Carlos, Universidade de São Paulo.

THAME, A. C (org.). A cobrança pelo uso da água. São Paulo: IQUAL, Instituto de Qualificação, LTDA, 2000. 256p.

THOMANN, R., MUELLER, J.A. Principles of surface water quality modeling and control. New York, USA: HarperCollinsPublishers Inc. 1987. 644 p.

USEPA, United Sates Environmental Protection Agency. "Rates, Constants and Kinetics - Formulation in Surface Water Quality Modeling, $2^{\circ}$ ed." Report $n^{\circ} \mathrm{EPA} / 600 / 3-85 / 040$. Environmental Research Laboratory, 1985.

USEPA, United Sates Environmental Protection Agency. "Water Quality Criteria", Report EPA. Environmental Research Laboratory, 1989. 